Florida International University

FIU Digital Commons

$11-9-2020$

\title{
Long-Term and Seasonal Drivers of Phytoplankton Assembly in a Subtropical Monomictic Lake
}

Kristy Lee Sullivan

ksull027@fiu.edu

Follow this and additional works at: https://digitalcommons.fiu.edu/etd

Part of the Terrestrial and Aquatic Ecology Commons

\section{Recommended Citation}

Sullivan, Kristy Lee, "Long-Term and Seasonal Drivers of Phytoplankton Assembly in a Subtropical Monomictic Lake" (2020). FIU Electronic Theses and Dissertations. 4541.

https://digitalcommons.fiu.edu/etd/4541

This work is brought to you for free and open access by the University Graduate School at FIU Digital Commons. It has been accepted for inclusion in FIU Electronic Theses and Dissertations by an authorized administrator of FIU Digital Commons. For more information, please contact dcc@fiu.edu. 


\title{
FLORIDA INTERNATIONAL UNIVERSITY
}

Miami, Florida

\section{LONG-TERM AND SEASONAL DRIVERS OF PHYTOPLANKTON ASSEMBLY IN}

A SUBTROPICAL MONOMICTIC LAKE

\author{
A thesis submitted in partial fulfillment of \\ the requirements for the degree of \\ MASTER OF SCIENCE \\ in \\ BIOLOGY
}

by

Kristy Lee Sullivan 
To: Dean Michael R. Heithaus

College of Arts, Sciences and Education

This thesis, written by Kristy Lee Sullivan, and entitled Long-Term and Seasonal Drivers of Phytoplankton Assembly in a Subtropical Monomictic Lake, having been approved in respect to style and intellectual content, is referred to you for judgment.

We have read this thesis and recommend that it be approved.

John Kominoski

Rudolf Jaffé

Evelyn Gaiser, Major Professor

Date of Defense: November 9, 2020

The thesis of Kristy Lee Sullivan is approved.

Dean Michael R. Heithaus

College of Arts, Sciences and Education

Andrés G. Gil

Vice President for Research and Economic Development and Dean of the University Graduate School

Florida International University, 2020 


\section{ACKNOWLEDGMENTS}

Thank you to my advisor, Dr. Evelyn Gaiser for her guidance, humor, and kindness in my time at FIU Thank you to my committee members, Drs. Rudolf Jaffé and John Kominoski, for their support and help with the preparation of this thesis, and thank you to Dr. Sparkle Malone for help with time series analyses. I'd also like to acknowledge Franco Tobias and the FIU Periphyton Lab personnel for their help with field work, sample processing, and taxonomy, and former FIU undergraduate students Ileana Corsi and Kristen Dominguez for completing preliminary counts of some of the phytoplankton samples used in this project (2006-2014). I would like to thank Archbold Biological Station director Hilary Swain for her guidance and access to Archbold resources and field equipment. Lastly, I would like to thank Archbold staff, Nancy Deyrup and Kevin Main, for collecting a large portion of the data presented in this thesis, and the Florida LAKEWATCH program for providing water nutrient data. This thesis was developed in collaboration with the Florida Coastal Everglades Long Term Ecological Research program under Cooperative Agreement \#DEB-1832229. 


\title{
ABSTRACT OF THE THESIS \\ LONG-TERM AND SEASONAL DRIVERS OF PHYTOPLANKTON ASSEMBLY IN \\ A SUBTROPICAL MONOMICTIC LAKE \\ by
}

\author{
Kristy Lee Sullivan \\ Florida International University, 2020 \\ Miami, Florida \\ Professor Evelyn Gaiser, Major Professor
}

Seasonal phytoplankton dynamics in lakes are highly sensitive physicochemical changes in the water column. As climate-driven frequency and variability of precipitation increases, lakes may experience increased inputs of allochthonous organic matter and nutrients through pulsed rain events. The resultant effects of lake physicochemistry on phytoplankton seasonal succession and assemblage are poorly understood. In the current study, the phytoplankton assemblage of a subtropical monomictic lake was examined in the context of natural interannual oscillations in allochthonous dissolved organic carbon and nutrient inputs resulting in prolonged clear-water and dark-water phases over a 14year period. Differences in water clarity and nutrient concentrations among phases caused pronounced assemblage and morphology-based functional grouping shifts largely associated with hydrologic effects of the Pacific Decadal Oscillation. Determining how phytoplankton assemblages respond to changes in allochthonous supplies is critical to understanding and predicting the cascading effects of climate on lake ecosystems at all latitudes. 


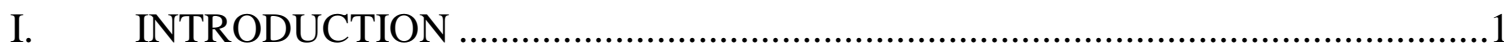

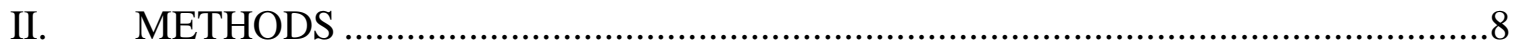

Study site

Physicochemical sampling and analysis ..................................................................

Phytoplankton sampling, identification, and enumeration .............................................10

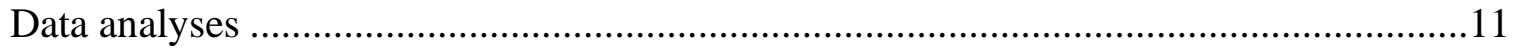

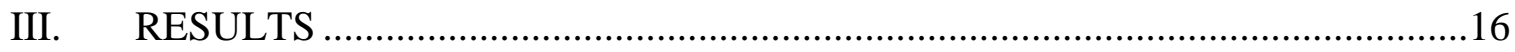

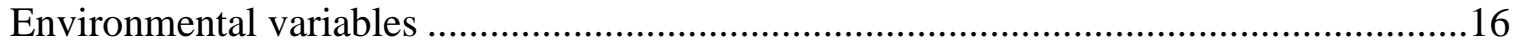

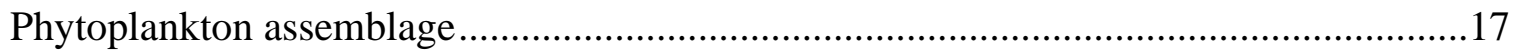

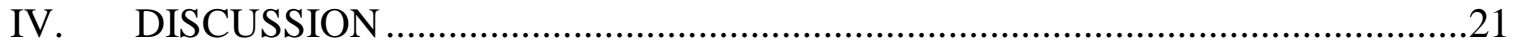

Lake hydrology and physicochemistry ………………….......................................21

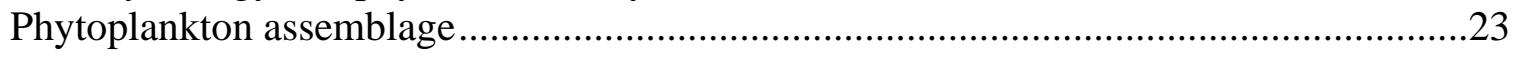

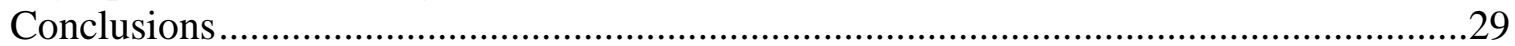

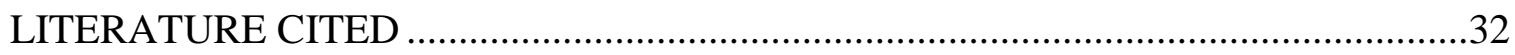

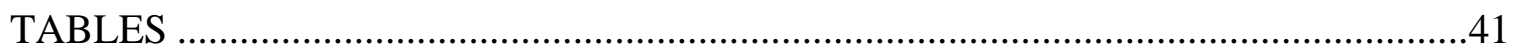

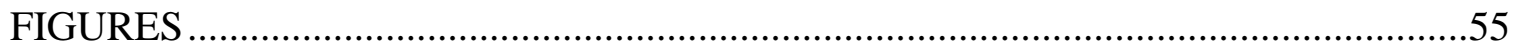

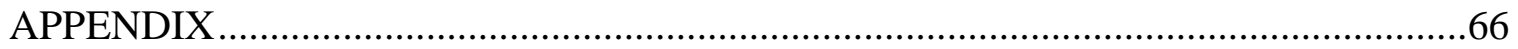


1. Mean \pm standard error (SE) of physicochemical variables for the dark (PCU > 30 ) and clear (PCU < 30) phases. Dark phases 1 and 2 (January 2005 - October 2007 and October 2012 - December 2019) were grouped for comparisons with the clear phase (November 2007 - September 2012)

2. Pearson correlation matrix of monthly physicochemical driver variables from January 2005 - December 2019

3. Taxa identified in Lake Annie throughout the 14-year study period.

4. Correlation coefficients for physicochemical vectors with axis 1 and 2 of the clear and dark phase NMDS based on taxon relative biovolumes (Fig. 7) 
1. Conceptual diagram of anticipated drivers of phytoplankton succession in darkwater (left) and clear-water (right) conditions

2. Monthly mean ground water stage (solid line), quarterly surface water color (dashed line), and monthly mean Pacific Decadal Oscillation index (PDO) values (bars)

3. Mean monthly photosynthetically active radiation (PAR) extinction rate $\left(\mathrm{K}_{\mathrm{d}}\right.$ $\left.\mathrm{m}^{-1}\right) \pm$ standard error (SE) for the time period January 2005-December 2019

4. Timeseries of phytoplankton relative cell density (left) and relative biovolume (right) of Bacillariophyta, Charophyta, Chlorophyta, Ochrophyta (Crysophytes and Synurophytes), Dinoflagellata (Miozoa), and Cyanophyta.

5. Two-dimensional NMDS ordination biplot of monthly phytoplankton taxon relative biovolume

6. Change in Bray-Curtis similarity across sample pairs collected 1 to 170 months apart (October 2005-December 2019)

7. Decomposed time series showing the trend of water color (solid line) and phytoplankton relative biovolume NMDS axis 1 score (dashed line) from January 2005-December 2019

8. Two-dimensional NMDS ordination biplot of monthly phytoplankton relative taxon biovolume for dark phases 1 and 2 combined (a) and clear phase (b) coded by season

9. Example two-dimensional NMDS ordination biplots of phytoplankton relative taxon biovolume with monthly trajectories during a dark year (a, 2017) and a clear year $(b, 2011)$

10. Mean percent contribution to relative biovolume of each morphology-based functional group (MBFG) in dark (a) and clear (b) phase years 
11. Two-dimensional NMDS ordination biplot of taxon relative biovolumes with bubbles scaled to the percent contribution of each functional group to total sample biovolume in dark (black bubbles) and clear ( light grey bubbles)

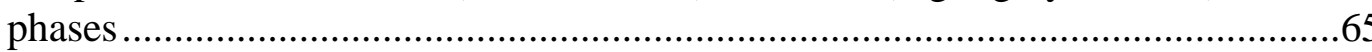


AMO - Atlantic Multidecadal Oscillation

Chl- $a$ - Chlorophyll- $a$

DOC - dissolved organic carbon

ENSO - El Niño Southern Oscillation

MBFG - morphology-based functional group

NMDS - non-metric multidimensional scaling

PAR - photosynthetically active radiation

PCU - platinum cobalt unit

PDO - Pacific Decadal Oscillation

PFD - photon flux density

PPT - end of month precipitation total

SOI - Southern Oscillation Index

$\mathrm{TN}$ - total nitrogen

TOC - total organic carbon

TP - total phosphorus 


\section{INTRODUCTION}

Physicochemical dynamics and resultant phenological and trait-driven species responses tend to drive a predictable sequence of phytoplankton dominance in most lakes (Hutchinson 1961, Reynolds 1984). Since its inception, the Plankton Ecology Group’s (PEG) description of the succession of lake biota (Sommer et al. 1986) has been expanded to include interactions between phytoplankton and the microbial loop, parasitism, and grazing (Sommer et al. 2012) among lakes of different climate regions and mixing cycles (De Senerpont Domis et al. 2013). Despite the utility of these successional models in understanding the drivers of assembly change over time, analysis of long-term phytoplankton data show that successional patterns can be highly sensitive to interannual variability in climate drivers and resulting seasonal physicochemical dynamics (Winder and Sommer 2012, Carey et al. 2016, Anneville et al. 2018, AlvarezCobelas et al. 2019). Determining how phytoplankton succession responds to variability in climate drivers of lake dynamics is essential to predicting the cascading effects of climate change on lake ecosystems.

Globally, precipitation variability is expected to increase $3-4 \%$ by the end of the century (Pendergrass et al. 2017), increasing the frequency of extreme drought and rainfall events and causing already wet regions to become wetter and dry regions to become drier (Adrian et al. 2009, Jennings et al. 2012, Jeppesen et al. 2015, Stockwell et al. 2020, Woolway et al. 2020). Variability in precipitation is a function of complex interactions among teleconnections and regional conditions (Abiy et al. 2019, Woolway et al. 2020), and lakes around the globe show strong sensitivities to changes in 
precipitation variability (Adrian et al. 2009). Global climate teleconnections such as the El Niño Southern Oscillation (ENSO), Pacific Decadal Oscillation (PDO), and Atlantic Multidecadal Oscillation (AMO) drive precipitation patterns across large areas on interannual and multidecadal timescales (Kiladis and Diaz 1989, Mantua and Hare 2002, Knight et al. 2006). These teleconnections have been correlated with periods of low and high water levels (Harris and Baxter 1996, Swancar 2005, Ghanbari and Bravo 2008), ice cover duration (Ghanbari et al. 2009), stratification duration (Winder and Schindler 2004) and water clarity (Gaiser et al. 2009b) in lakes. Because teleconnections occur over such long timescales, it is often difficult to discern the effects of these oscillations from climate change, even in lakes in remote locations minimally disturbed by local human activity (Woolway et al. 2020).

Variability in precipitation influences lake chemistry directly and indirectly by changing interactions between the lake and surrounding watershed (Woolway et al. 2020). Droughts or dry periods reduce allochthonous inputs to lakes, lower water levels, and increase water residence time, which can increase surface water temperatures and ion concentrations (Schindler et al. 1997, Flanagan et al. 2009, Tweed et al. 2009). Following periods of extended watershed dryness where soil organic matter is oxidized, intense or even moderate rainfall may result in a large pulse of mineralized allochthonous organic matter and nutrient runoff to lakes (Solomon et al. 2015, Meyer-Jacob et al. 2019, Stockwell et al. 2020). Since allochthonous dissolved organic carbon (DOC) is often highly colored, precipitation and resultant runoff events can lead to lake browning (Bertilsson and Tranvik 2000, Hanson et al. 2011). Surface water browning is expected to 
increase in wet climates as a result of continuous groundwater inundation (de Wit et al. 2016).

The reduction of photic zone depth with browning may cause warmer epilimnions while cooling hypolimnetic temperatures and reducing stratification depth (Gaiser et al. 2009a, Solomon et al. 2015, Olson et al. 2020). Documented biological effects of lake browning include reduced primary productivity, biodiversity, and fish and invertebrate production (Solomon et al. 2015, Pilla et al. 2018, Kritzberg et al. 2020). However, concomitant inputs of allochthonous nutrients may promote primary productivity if colored DOC does not exceed levels that elicit light-limitation. Therefore, gross primary production tends to follow a hump-shaped relationship to colored DOC (Kelly et al. 2018, Olson et al. 2020). Despite these recent advances in understanding the relationship between DOC and productivity, the long-term effects of altered thermal stratification and light penetration on phytoplankton successional dynamics and composition is uncertain (Olson et al. 2020, Stockwell et al. 2020).

As most phytoplankton are non-motile or very weakly motile, they are often the first group of lake biota to respond to the physicochemical effects of lake browning (Kritzberg et al. 2020). Examining the relationship between phytoplankton assembly and environmental change using functional group or trait-based approaches can improve understanding and prediction of community change (Reynolds et al. 2002, Litchman et al. 2007, Salmaso et al. 2014, Weiss and Ray 2019). Functional trait analyses foster comparisons of resource acquisition strategies, edibility, and physiological trade-offs that determine which taxa persist or thrive in certain physicochemical and biological 
conditions (Litchman et al. 2007). A morphology-based functional grouping (MBFG) approach uses structure-specific details (Kruk et al. 2010, Salmaso et al. 2014) to model succession (Segura et al. 2013) and predict environmental conditions (Kruk et al. 2011), including phytoplankton responses to major weather events (Stockwell et al. 2020).

Global climate and regional land-use changes are affecting the succession and phenology of lake phytoplankton as well as the frequency and severity of algal blooms in many lake ecosystems (Weyhenmeyer 2001, Adrian et al. 2009, O’Reilly et al. 2015, Anneville et al. 2018). Insight into how these changes in external drivers are changing phytoplankton successional dynamics is increasingly available from long-term and high resolution limnological and meteorological datasets (Rühland et al. 2015, Carey et al. 2016, Anneville et al. 2018, Alvarez-Cobelas et al. 2019). Teleconnections have been correlated to variation in phytoplankton biomass in various lakes, but fewer studies have examined the direct impacts of climate oscillations and anomalies on phytoplankton assembly and periodicity (Harris and Baxter 1996, Anneville et al. 2018, AlvarezCobelas et al. 2019). As lakes continue to warm, and precipitation becomes more variable, studying the effects of climate on phytoplankton at different latitudes may provide insight into the interannual to multidecadal patterns in phytoplankton dynamics with future climate conditions (Adrian et al. 2009, Anneville et al. 2018).

Within the next century, the effects of increasing surface water temperatures and altered precipitation patterns may result in shorter durations of ice cover and changed mixing regimes in lakes worldwide (O'Reilly et al. 2015, Jennings et al. 2015, Woolway and Merchant 2019, Stockwell et al. 2020, Woolway et al. 2020). Lakes that do not 
currently experience ice cover are predicted to become permanently stratified systems (meromictic), while lakes that experience seasonal periods of ice-cover are predicted to transition from dimictic to monomictic mixing regimes (Ficker et al. 2017, Woolway and Merchant 2019, Woolway et al. 2020). Lakes that are currently meromictic or monomictic may serve as important analogs for understanding climate-driven changes in respective monomictic and dimictic lake ecosystems (Porter et al. 1996). Subtropical monomictic lakes such as Lake Annie (Highlands County, Florida, USA) serve as important analogs for understanding climate-driven changes in dimictic lake ecosystems (Porter et al. 1996). Lake Annie is uniquely low-nutrient (meso-oligotrophic) compared to other lakes in the South-Central Florida region, most of which are impacted by eutrophication linked to agricultural runoff (Stauffer 1991, Havens 1995). Long-term (30+ year) patterns in water clarity and physicochemical dynamics reflect multi-year fluctuations in precipitation patterns strongly driven by the AMO (Gaiser et al. 2009a, Gaiser et al. 2009b). The lake is roughly $80-90 \%$ groundwater fed during the cold AMO phase, but it receives large influxes of surface water during periods of intense or prolonged rainfall associated with the warm AMO phase (Battoe 1987, Sacks et al. 1998). During the warm (positive) AMO phase, the South-Central Florida region tends to experience higher frequencies of storm activity and heavy rainfall (Enfield et al. 2001, Curtis 2008). Water table increases cause greater surface and groundwater inflows to Lake Annie, which increase lake water stage and concentrations of allochthonous, colored DOC (Fig. 1, Gaiser et al. 2009a, Gaiser et al. 2009b). In contrast, the cold (negative) AMO phase reduces the amount and intensity of precipitation in Florida (Enfield et al. 2001, Curtis 2008). In the Lake Annie watershed during negative AMO, 
ground water stage is low, and rain tends to seep into the ground rather than run off as overland flow into the lake. With low allochthonous DOC input, water clarity tends to increase in these years (Gaiser et al. 2009b). Although AMO phases occur in 20-40 year intervals, precipitation patterns in Florida are also influenced by shorter timescale teleconnections such as PDO (Kurtzman and Scanlon 2007) and ENSO (Enfield et al. 2001, Schmidt et al. 2001).

As a result of Lake Annie's strong sensitivity to climate oscillations and resulting precipitation patterns, we predicted seasonal and interannual hydrologic drivers would strongly regulate phytoplankton succession via influences of light, nutrients, and thermal stability (H1). During years where water color measured as platinum cobalt units (PCU) was dark (PCU > 30), we expected greater variability in intra-annual precipitation to cause differences in wet-dry season hydrology. We predicted these strong seasonal changes in hydrology to regulate phytoplankton dynamics such that the mode of succession would follow the trends generally observed in temperate lakes (H1a). During years where water had increased transparency $(\mathrm{PCU}<30)$, we expected decreased variability in intra-annual precipitation to lessen the difference between wet-dry season hydrology. We predicted a lack of strong seasonal hydrologic trends in lake physicochemistry to cause a decrease in the seasonal trends of phytoplankton succession (H1b). During the clear years with less pronounced seasonal hydrology we anticipated more subtle assemblage changes regulated by biological than abiotic interactions than in dark years (H2). As global temperature and precipitation patterns continue to change, determining the responses of phytoplankton to variable climate drivers is essential to 
understanding and predicting the cascading effects of climate change on lake ecosystems at all latitudes. 


\section{METHODS}

Study site

Lake Annie is a small yet deep $\left(0.364 \mathrm{~km}^{2}, \mathrm{Zmax}=21 \mathrm{~m}\right)$ subtropical monomictic lake located in Highlands County, Florida, USA $\left(27^{\circ} 12^{\prime} 35^{\prime}\right.$ N, $\left.81^{\circ} 20^{\prime} 57^{\prime \prime} \mathrm{W}\right)$. From the study period of October 2005 to December 2019, surface water chlorophyll- $a$ (Chl- $a$ ) concentrations ranged from 1-12 $\mu \mathrm{g} \mathrm{L}^{-1}$ (mean $4 \mu \mathrm{g} \mathrm{L}^{-1}$ ) and total phosphorus (TP) ranged from 1.2-23.8 $\mu \mathrm{g} \mathrm{L}^{-1}$ (mean $6.2 \mu \mathrm{g} \mathrm{L}^{-1}$ ) classifying Lake Annie a mesooligotrophic lake (Carlson and Simpson 1996). The doline lake is $33.7 \mathrm{~m}$ above mean sea level (amsl) on 60-80 m of sand and clay sediment (Bishop 1956). It lies within the protected watershed of Archbold Biological Station (Archbold) where a monthly limnological monitoring program was initiated in 1984. It became part of the Global Lakes Ecological Observatory Network (GLEON) in February 2008 (Gaiser et al. 2009a, Gaiser et al. 2009b).

\section{Physicochemical sampling and analysis}

Monthly limnological sampling was initiated by Larry Battoe at Archbold in September 1983 (Battoe and Lowe 1992) and supplemented with plankton sampling since 2005. The data presented in this study were collected from the water column at the deepest point of in the lake $(20.7 \mathrm{~m})$ on a monthly basis between 09:00h and 15:00h. The sampling repertoire includes measurements of dissolved oxygen (DO) and temperature using a YSI Model 58 portable meter and $\mathrm{pH}$ with a YSI Pro handheld meter at 1-meter intervals up and down the water column to produce duplicate measurements. Thermal structure measurements including thermocline depth and Schmidt stability were 
calculated from temperature profiles in RStudio v. 1.2.5001 (R Core Team 2019) using the rLakeAnalyzer package (Winslow et al. 2019). Oxycline depth was determined as the depth where dissolved oxygen concentration was less than $0.5 \mathrm{mg} \mathrm{L}^{-1}$.

Light penetration as photon flux density (PFD) of photosynthetically active radiation relative to surface PFD was measured at 1-meter intervals using a LiCor LI188B Integrating Photometer with 2 pi surface and underwater sensors. Ambient PFD was first measured for 10 s above the water surface and then for 10 s underwater every meter to $20 \mathrm{~m}$ in duplicate. Photosynthetically active radiation (PAR) extinction rate was then calculated by subtracting the natural logarithm of irradiance at a given depth in meters from the natural logarithm of surface irradiance, and dividing by depth in meters from the surface $(0 \mathrm{~m})$. The measurement was repeated for each meter of depth in the lake up to $20 \mathrm{~m}$. The slope of the resulting regression of light transmission for each depth was used as the final measurement of extinction rate $\left(\mathrm{K}_{\mathrm{d}} \mathrm{m}^{-1}\right)$.

Secchi disc depth was measured twice to the nearest $\mathrm{cm}$ on the shady side of the boat. Surface water samples were taken for analysis of total organic carbon (TOC), DOC, Chl- $a$, TP, total nitrogen (TN), and water color. Water color was measured using the platinum-cobalt scale and reported as PCUs quarterly. Samples for TOC and DOC were stored in the dark at $4^{\circ} \mathrm{C}$ until analysis at Florida International University (FIU). After acidifying to $\mathrm{pH}<2$, and purging with $\mathrm{CO}_{2}$-free air, TOC was measured by direct injection onto hot platinum catalyst in a Shimadzu TOC-5000 analyzer. The same method was used to measure DOC after filtration through a $0.45 \mu \mathrm{m}$ ashed filter. Up to $1-\mathrm{L}$ of surface water was filtered onto a $0.45 \mu \mathrm{m}$ filter for analysis of Chl- $a$ by 
spectrophotometry. Samples for TP, TN, and water color were frozen and retrieved by the Florida LAKEWATCH program for colorimetric and spectrophotometric analyses (Florida LAKEWATCH, 2020).

End of month totals of precipitation were calculated from Archbold's National Weather Service Main Grounds Weather Station with measurements collected every 15 minutes. Monthly average lake water stage was calculated from weekly measurements of a USGS well installed $2.5 \mathrm{~km}$ upslope from the lake at $63.7 \mathrm{~m}$ amsl in the Red Hill watershed. Measurements of mean ground water stage were calculated from weekly well depth measurements collected by the Southwest Florida Water Management District (SWFWMD) at a georeferenced stage recorder installed near the northern outlet of the lake. Teleconnection index values for the AMO, PDO, and southern oscillation index (SOI) values were obtained from the National Oceanic and Atmospheric Administration (NOAA) National Centers for Environmental Information website.

\section{Phytoplankton sampling, identification, and enumeration}

Vertical net tows were taken from $10 \mathrm{~m}$ at the deepest point in the lake using a $20-\mu \mathrm{m}$ mesh phytoplankton net. The resulting concentrated samples were collected in $250 \mathrm{~mL}$ plastic bottles and preserved with $50 \%$ glutaraldehyde solution to a final concentration of approximately $1 \%$. Two samples were collected and preserved within an hour of collection. Samples were stored at Archbold in the dark at $4^{\circ} \mathrm{C}$ until transportation on ice to FIU for identification and enumeration. At FIU, samples were settled for at least 12 hours in $50 \mathrm{~mL}$ glass test tubes and then decanted to a final volume of approximately $7 \mathrm{~mL}$. A subsample of each concentrated phytoplankton sample was mounted onto a 
semi-permanent slide and enumerated for relative phytoplankton abundance using either a Zeiss Axioskop 2 microscope at 640× magnification on a Nikon Eclipse E600 microscope at $600 \times$ magnification. Individuals and colonies were identified to the lowest taxonomic level. An initial 250 units were counted and identified, followed by an additional 250 units where all taxa were counted, but only rare taxa (those not seen in the initial count) were recorded.

\section{Data analyses}

Since not all DOC is colored (Bertilsson and Tranvik 2000), water color as PCUs was chosen as the metric of water transparency. For all variable analyses, the time series was broken into three phases defined by shifts in water color above or below a threshold of 30 PCUs (Fig. 2). Canfield et al. (1984) previously classified Florida lakes as colored (dark) during periods when water color was greater than 20 PCUs, but 30 PCUs was used in this study as water color was consistently below this threshold for an extended period of time. Groupings include phases dark 1 (October 2005—June 2007), clear (July 2007 September 2012), and dark 2 (October 2012 - December 2019). In order to create a decomposed trend line of water color, missing data were interpolated by averaging the prior and subsequent values to form a continuous time series. The timeseries was decomposed using moving averages with a multiplicative model. A Chow test for a structural break was used to determine significant differences between dark and clear phase water color trends using base R statistical functions in RStudio v. 1.2.5001 (Chow 1960, R Core Team, 2019). Phases dark 1 and clear phase demonstrate a structural break $\left(\right.$ Chow statistic $\left.=193.73, \mathrm{~F}_{\text {crit }}=1.69\right)$ as well as clear phase and dark $2($ Chow statistic $=$ 
59.55, $\left.\mathrm{F}_{\text {crit }}=1.50\right)$. These results were supported by Tukey HSD test results following a one-way ANOVA of the three groups (dark 1, clear, and dark 2) for both water color and ground water stage calculating using PAST statistical software (Hammer et al. 2001).

Averages with standard error (SE) of 17 environmental variables were calculated for dark and clear phases. Variables include AMO Index, PDO index, SOI, precipitation as end of month total, monthly mean ground water stage and lake water stage as m amsl, Secchi disk depth in $\mathrm{m}$, PAR extinction rate as $\mathrm{K}_{\mathrm{d}} \mathrm{m}^{-1}$, TOC and DOC in $\mathrm{mg} \mathrm{L}^{-1}$, water color as PCUs, thermocline depth in $\mathrm{m}$, Schmidt stability as $\mathrm{J} \mathrm{m}^{-2}$, oxycline depth in $\mathrm{m}$, monthly mean $\mathrm{pH}$, TP in ug $\mathrm{L}^{-1}$, and $\mathrm{TN}$ in $\mathrm{mg} \mathrm{L}^{-1}$. Welch's t-test was used to determine differences $(\mathrm{p}<0.05)$ between phases of unequal sample size using PAST statistical software (Hammer et al. 2001). The t-scores were also reported as a measure of the size of the difference. Correlations between variables were calculated and visualized within a Pearson correlation matrix also using PAST (Hammer et al. 2001).

Raw phytoplankton data were digitized and proofed for data entry errors. Missing samples for months April 2006, November 2006, January 2013, and June 2017 were excluded from all analyses except for time series analyses where values were interpolated. Taxon richness, Shannon diversity, taxon cell density (cells $\mathrm{mL}^{-1}$ ) and taxon biovolume $\left(\mathrm{um}^{3} \mathrm{~mL}^{-1}\right.$ ) were calculated for each sample. Taxon cell densities and biovolumes were converted to relative cell density and relative biovolume (\% of total sample). Timeseries of these data were plotted for each higher taxonomic level. Each taxon was assigned to one of eight functional groups following the outline of seven phytoplankton MBFGs proposed by Kruk et al. (2010). The MBFG groups include 1) 
small organisms with high surface area to volume ratio, 2) small flagellated organisms with siliceous exoskeletal structures, 3) large filaments with aerotopes, 4) medium size organisms lacking specialized traits, 5) medium to large size unicellular flagellates, 6) non-flagellated organisms with siliceous exoskeletons, 7) large mucilaginous colonies, and 8) large filaments lacking aerotopes. The eighth group was added by the authors to separate filamentous Charophyta and Chlorophyta from MBFG group 4. Taxa

undescribed by Kruk et al. (2010), but present in Lake Annie were assigned to the closest functional group on the basis of their morphology. Average percent contribution to biovolume of each functional group in the dark and clear years was plotted by month to revisualize the phytoplankton assemblage.

Multivariate analyses including non-metric multidimensional scaling (NMDS) ordinations were constructed using PRIMER-E v. 7.0.13 (Clarke and Gorley 2015) software to visualize potential dissimilarity among phytoplankton assemblages in dark and clear phases. Prior to any analysis, monthly samples of taxon relative biovolumes were arcsin square-root transformed and a cluster analysis by group average was used to determine and remove outlier samples. Samples falling outside of the two primary clusters at the $24 \%$ similarity slice were removed from further analyses to reduce stress. Following the remaining results of the relative taxon biovolume-based cluster analysis, samples were reorganized into three groups: dark 1 (October 2005-November 2009), clear (December 2009-August 2013, and dark 2 (September 2013-December 2019). A similarity percentage breakdown (SIMPER) was used to calculate the contribution of each taxon to the dissimilarity between the three phases. Dark phase 1 and 2 were then combined and compared with clear phase using the same analysis. Welch's t-tests were 
performed using taxon richness, Shannon diversity, and Chl- $a$ metrics as a univariate measure of difference between dark and clear phases $(\mathrm{p}=0.05)$ using PAST statistical software (Hammer et al. 2001).

A Bray-Curtis similarity index of samples was used to create a resemblance matrix using similarities in taxon relative abundances in PRIMER (Clark and Gorley 2015). To observe trends over time, sample similarity data were plotted as a scatter plot using months between samples as the independent variable (Fig. 6). Two one-way analyses of similarity (ANOSIM) were also performed on the resemblance matrix data in PRIMER (Clark and Gorley 2015). Samples were grouped by phase (dark 1, clear, and dark 2) and then by dark phases combined vs. clear phase. Results were generated after 1,000 permutations, and analyses had a significance level of $0.1 \%$. The resemblance matrix was then used to generate a two-dimensional NMDS ordination plot using 1,000 restarts. Ellipses were drawn around samples that were $>25 \%$ similar. The twodimensional ordination was rotated so that axis 1 was most strongly correlated with time (year). Then, axis 1 scores for each sample point were plotted as a decomposed time series in RStudio (R Core Team 2019) using moving averages with a multiplicative model. The time series was compared with the decomposed trend line of water color to assess lag-time and assemblage change with water color. Missing data were interpolated by averaging the prior and subsequent values to form a continuous time series. A Chow test was used to test the significance of structural changes in the ordinations' axis 1 values regressed by time (Chow 1960, R Core Team 2019). A total of 17 environmental variables (Table 1) were included as potential explanatory variables and those explaining $>30 \%$ of variation in the final NMDS solution were plotted as vectors. The ordination 
was revisualized into eight relative abundance MBFG bubble plots to further understand the distribution of MBFGs between dark and clear phases. Subsequent NMDS plots were created using subsets of the resemblance matrix, including independent dark and clear phase plots with samples grouped by season, and independent annual trajectory plots. A two-way nested ANOSIM was used to measure difference in seasons between dark and clear phase samples. Results were generated after 1,000 permutation, and the analysis had a significance level of $2.9 \%$. 


\section{RESULTS}

\section{Environmental variables}

Mean monthly ground water stage was lower in clear years than dark years and was also positively correlated with water color $\left(\mathrm{R}^{2}=0.79\right.$, Table 2$)$. Water color measured as PCUs was higher in dark years than clear years, and though not different between dark 1-dark 2 groupings, there was a strong difference in clear phase (Fig. 2). The correlation of AMO and SOI with ground water stage was weak $\left(R^{2}=0.13\right.$ and $R^{2}=$ 0.08 , respectively). The PDO was found to have a stronger correlation with ground water stage $\left(\mathrm{R}^{2}=0.52\right)$ and water color $\left(\mathrm{R}^{2}=0.35\right)$.

Comparisons between dark and clear phase monthly average PAR extinction rate $\left(\mathrm{K}_{\mathrm{d}} \mathrm{m}^{-1}\right)$ indicates strong seasonal trends in transparency during dark phases (Table 1). In contrast, the clear phase monthly means show lack seasonality and variability (Fig. 3). Mean extinction rate for a given dark phase month was always greater than the corresponding clear phase month, with September and October showing the greatest difference in extinction rate between phases. Extinction rate was strongly correlated with ground water stage $\left(\mathrm{R}^{2}=0.80\right)$ and water color $\left(\mathrm{R}^{2}=0.92\right.$, Table 2$)$.

Of the 17 environmental variables, 13 differed between dark 1 and 2 and clear phase (Table 1), including PDO, SOI, ground water stage, lake water stage, PAR extinction rate, TOC, DOC, water color, thermocline depth, $\mathrm{pH}$, TP, and TN. Mean annual maximum ground water stage and lake water stage were higher during the dark phases (40.6 and $33.9 \mathrm{~m}$ above mean sea level, respectively) and lower during clear phase (39.6 and $33.7 \mathrm{~m}$ above mean sea level, respectively), while there was no strong 
difference in thermocline depth and Schmidt stability between the two phases (12.1 and $448.4 \mathrm{~J} \mathrm{~m}^{-2}$, respectively for dark, 12.6 and $447.2 \mathrm{~J} \mathrm{~m}^{-2}$, respectively for clear). Strong correlations $\left(\mathrm{R}^{2}<-0.5\right.$ or $\left.>0.5\right)$ were found amongst all water clarity variables (Secchi depth, PAR extinction rate, TOC, DOC, and water color, Table 2).

\section{Phytoplankton assemblage}

A lag time of 25 months between the dark 1 to clear phase transition (November 2007) and the phytoplankton response (December 2009) was detected. A shorter lag time of 11 months was found between the original clear to dark 2 phase transition (October 2012) and the phytoplankton response (September 2013). Within the 167 monthly phytoplankton samples enumerated from October 2005-December 2019, a total of 279 taxa (morphologically distinct units) were identified from 8 phyla (Table 3). Average richness was not different between dark and clear phases (30.09 \pm 0.82 vs. $30.72 \pm 1.18$, respectively), however, Shannon diversity was different between dark and clear phases (1.66 \pm 0.05 vs. $1.96 \pm 0.05$, respectively). Chl- $a$ was higher in dark versus clear phases (4.65 \pm 0.22 vs. $2.68 \pm 0.19 \mu \mathrm{g} \mathrm{L}{ }^{-1}$, respectively). While dark years typically exhibited a late winter/early spring peak in Chl- $a$, and sometimes a second fall peak, clear years often lacked a spring Chl- $a$ peak but usually exhibited a fall peak.

A large centric diatom Urosolenia spp. was the most abundant diatom (Bacillariophyta) in the dark phases contributing to $13.81 \%$ dissimilarity between phases (Table 3). Occasional spikes of Asterionella formosa were also common during dark phases. The largest change in assemblage structure throughout the study period was the near disappearance of diatoms during the clear phase synchronized with an increase in 
Chrysophytes and Synurophytes (Ochrophyta, Fig 4). Synura petersenii and Mallomonas spp. dominated in the spring months during the clear phase and contributed to $7.12 \%$ of the dissimilarity between phases (Table 3). Charophyta were abundant throughout the time series with Staurodesmus triangularis v. inflatus dominating both dark and clear phase samples. Charophyta relative abundance decreased during clear phase, but relative biovolume increased, indicating the presence of larger species such as Mougeotia spp, Staurastrum novae-caesareae, and Staurastrum ophiura. Chlorophytes were also more abundant in the clear phase, although their biovolume contribution remained consistent throughout the study period. Dinoflagellates (Miozoa) rarely contributed to more than $10 \%$ of relative abundance but due to their large size, they frequently comprised a large portion of assemblage relative biovolume. Fusiperidinium wisconsinense and Peredinium bipes were the most common dinoflagellates during dark phases, $F$. wisconsinense was also common during clear phase. $F$. wisconsinsense and P. bipes contributed to $5.43 \%$ and $5.22 \%$ of the dissimilarity between phases, respectively (Table 3). Cyanobacteria relative abundance increased slightly during the clear phase, but their contribution to biovolume remained low throughout the study period.

A 2D NMDS ordination with a minimal stress of 0.22 was achieved based on taxon relative biovolume (Fig. 5). Collective results of a one-way ANOSIM and NMDS ordination showed groups clear and dark 2 were the most dissimilar (global R: 0.80), while dark 1 and dark 2 phases were the most similar (global R: 0.31). Dark 1 and clear groups were more similar but still distinct (global R: 0.45). A second one-way ANOSIM of the combined dark phases with clear phase had a global R of 0.62. All ANOSIM analyses were significant. The Secchi depth vector showed the greatest influence $\left(R^{2}=\right.$ - 
$0.64)$ aligned with axis 1 . The precipitation vector was almost orthogonal to other hydrology and water clarity vectors, suggesting greater influence on axis 2 . A Chow test of the relationship between axis 1 and time revealed a structural break between dark 1 and clear phase $\left(\right.$ Chow statistic $\left.=32.05, \mathrm{~F}_{\text {crit }}=1.69\right)$ as well as clear phase and dark 2 $\left(\right.$ Chow statistic $\left.=41.37, \mathrm{~F}_{\text {crit }}=1.63\right)$.

Seasonal and interannual trends in sample similarity were observed in the BrayCurtis resemblance matrix (Fig. 6). As expected in temporally autocorrelated datasets, similarity is highest among adjacent sample pairs, but was lowest around 6-year interval pairs. There is a noticeable seasonal trend in the first segment of the graph among samples with 1-4-year paired contrasts. This seasonal pattern then dissipated toward the middle of the time series and reappears in 10-14-year interval pairs, matching the dark and clear phase transition points.

The decomposed time series of NMDS axis 1 scores from Fig. 5 shows how phytoplankton assembly changes over time (Fig. 7). The time series exhibits a strong decrease in axis 1 score values from 2010 to mid-2013 following a similar decrease in water color PCUs from mid-2007 to 2013. The previously determined lag time of around 25 months from initial PCU decrease below 30 units and phytoplankton response was apparent, as well as the much shorter second lag between increase in PCU above 30 units and phytoplankton response.

The NMDS ordinations of the separate dark and clear phase communities (Fig. $8 a, 8 b)$ reveal differences in within-phase regulators. Vectors that explained at least $30 \%$ of the ordination in dark phases but not clear phase include PDO, ground water stage, 
TN, and Chl- $a$ (Table 4). Vectors that explained at least 30\% of the ordination in clear phase but not dark phases include SOI, precipitation, PAR extinction rate, and TP. There was not a strong seasonal difference between phases (ANOSIM $R=0.07$ ), however, a few dark years had 12-month return trajectories that were not evident in the clear years (Fig. 9a, 9b).

The same phytoplankton assemblage data visualized by MBFGs reveals strong trends in phytoplankton functional group distribution between dark and clear phases (Fig. 11). While some functional groups were similarly distributed between phases (MBFGs 1, 3, and 7), other groups displayed greater relative abundance in dark phases (MBFGs 4, 6, and 8), clear phase (MBFG 2) or transitional state (MBFG 5). During the clear phase, winter peaks of MBFG 2 were common, while in dark phase, these peaks were absent, likely replaced by MBFG 6 . Though MBFG 8 relative abundance was greater in the dark phase, average relative biovolume was roughly $20 \%$ greater in the clear phase (Fig. 10a, $10 b)$. 


\section{DISCUSSION}

Phytoplankton composition and assembly dynamics varied between and within wetter dark phases and drier clear phases in subtropical Lake Annie. Assemblage shifts between phases were related to differences in hydrologic drivers which altered the frequency and magnitude of seasonal allochthonous inputs and resultant water clarity and nutrient concentrations. Seasonal dynamics were more pronounced during times of high groundwater elevation, whereas during periods of low groundwater elevation, allochthonous drivers had a reduced role in regulating phytoplankton assemblage. Shifts in phytoplankton assemblage over time were largely explained by morphology-based functional groupings (MBFGs), which were influenced by the changes in water color and nutrients that oscillate with climate teleconnections.

\section{Lake hydrology and physicochemistry}

Many aspects of lake hydrology and physicochemistry were largely explained by the PDO, particularly ground water stage $\left(\mathrm{R}^{2}=0.52\right)$, whereas the response of Lake Annie's hydrology and water clarity to the multi-decadal signal of the AMO was not strong in this 14-year dataset (Table 2). Remaining interannual and seasonal variability that is not directly explained by the PDO could be attributed to complex interactions with other climate teleconnections (Woolway et al. 2020). On multidecadal timescales, the AMO warm phase may contribute to less rainy El Niño phases (Enfield et al. 2001) while PDO warm phases may enhance the strength of El Niño anomalies in Florida (Kurtzman and Scanlon 2007). In turn, SOI may also affect PDO amplitude via atmospheric interactions (Alexander et al. 2002, Mills and Walsh 2013). Despite the positive 
amplitude feedbacks between ENSO and PDO, the amplitude of both anomalies is weakened under a warmer climate. Under such conditions, predicted PDO amplitude decreases and shortened time scales (Zhang and Delworth 2016) may further contribute to long-term decreases in seasonal precipitation variability for the South-Central Florida region. This is supported by historical trends of decreased wet season (May-September) precipitation and increased dry season (October-April) precipitation from 1950-2008 (Irizarry-Ortiz et al. 2013).

High groundwater stage during the positive index periods of the PDO was associated with a stronger seasonal signal of PAR extinction driven by greater wet season allochthonous colored DOC input, while clear years were lacking a seasonal PAR signal (Fig. 3). During clear periods, precipitation was also less variable between wet-dry seasons and less intense with lower colored DOC concentrations, which increased water clarity throughout the year. Seasonal and interannual changes in photic depth were mostly explained by these changes in water color $\left(\mathrm{R}^{2}=0.92\right)$. Thermal stability was not significantly greater in dark phases than clear phases as originally hypothesized (Fig. 1). In most brown lakes, high-colored DOC concentrations and subsequent decreases in light penetration have an insulating effect on surface waters which promotes shallow, more stable summer thermoclines (Solomon et al. 2015, Pilla et al. 2018, Kritzberg et al. 2020). This trend holds across the multidecadal record of Lake Annie, as maximum summer thermocline depth decreased from 1997-present in response to the warm AMO phase (Gaiser et al. 2009b). However, during the brief period of clearer water in the present study (November 2007-September 2012), maximum summer thermocline depth did not 
increase as expected. This departure from expectations was caused by winter cold snaps in 2010 and 2011 and resulted in the coldest January holomictic conditions in this study, which contributed to the coldest summer hypolimnetic temperatures $\left(13^{\circ} \mathrm{C}\right)$, and greaterthan-expected stability during the clear phase.

Chlorophyll- $a$ peaks occurred after early and late wet-season rain events with low summer levels suggesting the top-down regulation of phytoplankton by zooplankton (Sommer et al. 1986, Sommer et al. 2012). Though seasonal Chl-a peak periodicity did not differ significantly between dark and clear phases, Chl- $a$ concentrations were lower during the clear phase than the dark phases due to lower allochthonous nutrient inputs (Table 1). During the dark phases, Chl- $a$ concentrations were higher than the clear phase likely due to greater allochthonous nutrient inputs. This suggests dark phase DOC concentrations were never great enough to limit light availability as predicted in the second portion of a modeled hump-shape relationship between DOC and gross primary production (Kelly et al. 2018). Instead DOC and Chl- $a$ exhibited a strong positive linear relationship $\left(R^{2}=0.45\right)$.

\section{Phytoplankton assemblage}

The strongest drivers of dissimilarity between dark and clear phase phytoplankton communities were variables related to changes in water clarity (Secchi depth, DOC, TOC, and photic depth, Fig. 5). Phytoplankton dissimilarity was lower between the first dark phase and clear phase assemblages (ANOSIM global $\mathrm{R}=0.45$ ) than with the second dark phase (ANOSIM global $\mathrm{R}=0.80$ ), suggesting the initial phytoplankton response to increased water clarity was not as strong as the response to re-browning. Lag time 
between the initial decrease in water color below 30 PCUs and phytoplankton response was also much longer (25 months) than the second lag in response to re-browning (11 months, Figs. 4, 7). The initial lag time may be longer due to an increase in water residence time during the clear phase, which was around 13.5 months instead of 9.1 months in dark phases. In a 1996 survey of ten Florida ridge lakes, Lake Annie received roughly $4-5 \times$ greater net ground water flow per year than the other lakes, yet the amount of rainfall received per year was moderate compared to the same lakes, suggesting Lake Annie may be more strongly influenced by precipitation than other lakes in the area (Sacks et al. 1998). Because the lake is more sensitive to precipitation trends, intense nutrient and allochthonous DOC pulses may be more frequent, driving phytoplankton assemblage changes. The stronger and faster phytoplankton assemblage responses to the second dark phase suggests that phytoplankton were more sensitive to browning and concurrent nutrient increases than they were to increases in light availability during the clear phase.

On interannual timescales, most lakes tend to exhibit a repeatable pattern of phytoplankton succession dictated by repeatable climate seasonality (Carey et al. 2016). Empirical studies of phytoplankton assembly dynamics have found that general seasonal succession patterns tend to hold across interannual timescales except in periods where biotic or abiotic regulators are abruptly or significantly disturbed. Long-term studies have associated shifts in seasonal succession with periods of drought (Harris and Baxter 1996, Findlay et al. 2001, Flanagan et al. 2009, Carey et al. 2016), artificially altered hydrology (Kamenir et al. 2004), climate-driven temperature and nutrient fluctuations (Alvarez- 
Cobelas et al. 2019), and re-oligotrophication (Anneville et al. 2018). Seasonal succession and representative taxonomic compositions were often altered following the disturbance (Kamenir et al. 2004, Carey et al. 2016, Anneville et al. 2018). In Lake Annie, seasonal phytoplankton dynamics were strongly regulated by regional precipitation and hydrology. The clear phase disrupted the pattern of succession represented in the prior dark phase through a possible two-fold sequential mechanism: 1) a lowered water table reduced the magnitude of allochthonous inflows of nutrients and colored DOC allowing for 2) an increased role of internal regulation by internal nutrient loading, competition, parasitism, and predation. The weakened connection between lake and watershed during the clear phase reduced the influence of wet-dry runoff (Fig. 3), resulting in the lack of relationship between seasonal phytoplankton changes and external drivers (Fig. 6, 9a, 9b).

The structure of Lake Annie phytoplankton assembly was perhaps best described in the context of MBFGs, which prioritize the relationship of species phenotypic traits rather than taxonomic linkages (Kruk et al. 2010). Phytoplankton MBFGs 2, 4, 6, and 8 showed strong responses to phase changes in water clarity. Specifically, MBFGs 4, 6 , and 8 (medium size organisms lacking specialized traits, non-flagellated organisms with siliceous exoskeletons, and large filaments lacking aerotopes, respectively) showed preference for dark phase conditions while MBFG 2 (small flagellated organisms with siliceous exoskeletal structures) was more common in clear phase (Fig. 10a, 10b, 11). The most obvious change in assemblage among phases was the unusually low abundance of diatoms (MBFG 6) in the clear phase, comprising just 2\% of total biovolume 
compared to $42 \%$ in the dark phase (Fig. 4). At least one other study has found prolonged low abundance of diatoms associated with a period of drought and low runoff, likely caused by altered nutrient availability or parasitism, as dissolved reactive silica (DRSi) was ample (Carey et al. 2016). In Lake Annie, DRSi depletion is not able to be ruled out as the cause of the diatom crash because DRSi concentrations were not measured throughout the course of this study. However, it is unlikely that silica was completely depleted due to a corresponding increase in the abundance of silica-scaled Synurophytes (MBFG 2) when diatoms were sparse. Most diatoms prioritize cellular division over storage, so populations are rarely maintained during periods of prolonged silica depletion. In contrast, Synurophytes can store physiologically active silicate in excess during periods of severe DRSi depletion, and thus their growth is only influenced by long-term exhaustion (Klaveness and Guillard 1975, Sandgren et al. 1996). If ambient DRSi concentrations were low during the clear phase, it is possible that Synurophytes were able to outcompete the common larger diatoms.

Smaller diatoms (e.g. Aulacoseira tenella) which have a similar silica content to Synurophytes (Klaveness and Guillard 1975) were likely underrepresented in this study because all samples were collected with a $20 \mu \mathrm{m}$ plankton net. Though Synurophytes are also in the nanoplankton size range, colonial arrangements (Synura spp.) and the presence of spines (Mallomonas spp.) may have prevented their underestimation in net tows. A greater abundance of small species were found during the clear phase including the desmid Cosmarium pseudotetracerium v. scotti and small colonial cyanobacteria such as Merismopedia spp. Smaller algae's greater surface area to volume ratio (S/V) increases nutrient uptake efficiency, and consequently may make them superior competitors in low- 
nutrient conditions (Wher 1989, Litchman et al. 2007). Rühland et al. (2008) noted largescale taxon shifts from large to small diatoms in the Northern Hemisphere since the $19^{\text {th }}$ century likely due to warming causing prolonged ice-free periods and altered mixing regimes. Other studies of small algal species such as diatoms and some cyanobacteria are also common during periods of decreased nutrient loading due to drought (Harris and Baxter 1996) or re-oligotrophication (Anneville et al. 2018). Slightly stronger thermal stability during the summer months of the clear phase may also have favored small or flagellated organisms which are better able to maintain their position in the water column during extended periods of stratification than large planktonic diatoms (Litchman et al. 2007, Stockwell et al. 2020). However, as there were no strong differences in stratification length or thermocline depth during the stratified period in Lake Annie between dark and clear phases, taxon shifts were likely more strongly driven by the significant changes in light and nutrient availability between phases.

The PEG model (Sommer et al. 1986) was useful for describing changes in phytoplankton assembly observed during Lake Annie's dark phase. Diatoms dominated during winter mixing and into spring when they were succeeded by green algae that dominated in summer. A second bloom of large diatoms often formed in late summer followed by a dominance of dinoflagellates as the lake began to mix (Fig. 10a). The large diatoms observed in the dark phases (Urosolenia spp., Tabellaria spp., Asterionella formosa, and Aulacoseira herzogii) are species often found in low-light turbid conditions (Reynolds et al. 2002, Stockwell et al. 2020). Though they are non-motile, the high surface-area shapes of these diatoms are favorable during precipitation-driven turbulent 
resuspension possibly caused by higher frequency and intensity of major precipitation events in the dark phase (Stockwell et al. 2020).

Mixotrophic flagellates, which use some degree of both phototrophy and heterotrophy as their mode of nutrition, are also characteristic of brown-water lakes (Wilken et al. 2017, Kritzberg et al. 2020), but were lacking during the dark phases in Lake Annie. Prior studies of Swedish lakes have determined shifts from net phototrophy to net mixotrophy to occur around a threshold of 10-11 mg/L (Jansson et al. 2000, Bergström and Karlsson 2019), and at its darkest, Lake Annie had an average DOC concentration of $10.5 \mathrm{mg} / \mathrm{L}$. As Lake Annie's dark phases were on the cusp of this threshold, the staining may not have been severe enough to stimulate phytoplankton mixotrophy. Notably, one mixotrophic Raphidophyte Gonyostomum semen was observed more-frequently in the dark than clear phase but remained a rare taxon throughout the study. However, bacterial abundance and productivity, which were not measured, may have increased during this time period. As lake warming and browning are now occurring at unprecedented rates, increased bacterial abundance and reduced light may increase the occurrence of mixotrophic strategies (Wilken et al. 2017, Kritzberg et al. 2019).

Although recent studies of lake browning have found mixotrophic species to be the dominant phototrophs, mixotrophic dinoflagellates and Chrysophytes are also common in clear-water lakes, particularly when external nutrient supplies are suppressed by drought (Lydén and Grahn 1985, Findlay et al. 2001). In these environments, mixotrophy may be favorable as bacteria are usually abundant and can serve as a substitute carbon source for lacking external inputs (Bird and Kalff 1987). In Lake Annie, 
dinoflagellates showed no strong preference for clear or dark phase, though mixotrophic Dinobryon species were more common in the clear phase suggesting carbon deficiencies, rather than light scarcity, were the primary driver of Dinobryon presence. In the clear phase when diatoms were in very low abundance, succession was less repeatable across years, but always began with a late winter or early spring peak of Ochrophytes, usually Synura petersonii. Green algae dominated throughout the late spring to early fall, when dinoflagellates again gained dominance (Fig. 10b). While spring Ochrophyte blooms are common in oligotrophic lakes (Sommer et al. 1986), the absence of any apparent diatom seasonality is unusual and likely contributed to the lack of repeatability of these trends.

\section{Conclusions}

In temperate lakes, browning generally causes disruptions to archetypal phytoplankton dynamics (Wilken et al. 2017, Kritzberg et al. 2020), yet in Lake Annie, seasonal phytoplankton dynamics depend on the pulses of colored DOC and nutrients driven by seasonal wet-dry hydrology. When strong seasonal hydrology is lacking, the phytoplankton assemblage in Lake Annie is likely more strongly influenced by internal factors such as competition and predation, and repeatable succession patterns that are often externally/abiotically regulated disappear. In other lakes, the duration and intensity of hydrologic alterations may result in short-term (Harris and Baxter 1996, Carey et al. 2016) or seemingly permanent alterations in phytoplankton assemblage (Kamenir et al. 2004). While ambient DOC concentration in this study were never high enough to cause a decline in primary production (Chl-a), interannual phytoplankton assemblage was altered when water color was darker than 30 PCUs. This suggests phytoplankton 
assemblages may give more insight into the biological responses to allochthonous DOC, which are not apparent when examining Chl- $a$ as a univariate measure of primary production.

Simple changes to the lake monitoring program could greatly improve the resolution of the phytoplankton data described in this study. We recommend transitioning to an integrated water column phytoplankton sampling method from the previous method of collection by a vertical net tow with $20 \mu \mathrm{m}$ mesh so that phytoplankton in the nanoplankton size range $(<20 \mu \mathrm{m}$ diameter) are not underrepresented. Additionally, quarterly monitoring of dissolved reactive silica (DRSi) could improve our understanding of long-term variability in silica bioavailability and its relation to diatom population dynamics. While the integration of old and new data collected with different instruments or methods can be challenging, we believe the addition of these measures will be greatly beneficial to the quality of the phytoplankton dataset.

As summer algae bloom frequency is predicted to increase by $20 \%$ in the next century (O'Reilly et al. 2015), understanding how climate change and variability is influencing the magnitude and timing of phytoplankton blooms is essential to our understanding of broader lake food webs and ecosystem functions (Weyhenmeyer 2001, Straile 2002, Thackeray et al. 2008, Adrian et al. 2009). As the variability of rainfall continues to change on a global scale (Winder and Sommer 2012, Jennings et al. 2012, Stockwell et al. 2020, Woolway et al. 2020), subtropical lakes that are already strongly influenced by regional hydrology could serve as important analogs for the potential 
responses of dimictic lakes to climate change as they transition to monomictic thermal regimes. 


\section{LITERATURE CITED}

Abiy, A. Z., Melesse, A. M., and Abtew, W. 2019. Teleconnection of regional drought to ENSO, PDO, and AMO: Southern Florida and the Everglades. Atmosphere, 10(6): 295.

Adrian, R., O’Reilly, C. M., Zagarese, H., Baines, S. B., Hessen, D. O., Keller, W., Livingstone, D. M., Sommaruga, R., Straile, D., Van Donk, E., Weyhenmeyer, G. A., and Winder, M. 2009. Lakes as sentinels of climate change. Limnology and Oceanography. 54(6): 2283-2297.

Alexander, M. A., Bladé, I., Newman, M., Lanzante, J. R., Lau, N. C., and Scott, J. D. 2002. The atmospheric bridge: The influence of ENSO teleconnections on air-sea interactions over the global oceans. Journal of Climate. 15(16): 2205-2231.

Alvarez-Cobelas, M., Rojo, C., and Benavent-Corai, J. 2019. Long-term phytoplankton dynamics in a complex temporal realm. Scientific Reports. 9: 15967.

Anneville, O., Dur, G., Rimet, F., and Souissi, S. 2018. Plasticity in phytoplankton annual periodicity: an adaptation to long-term environmental changes. Hydrobiologia. 824: 121-141.

Austin, J. A. and Colman, S. M. 2007. Lake Superior summer water temperatures are increasing more rapidly than regional air temperatures: A positive ice-albedo feedback. Geophysical Research Letters. 34(6).

Battoe, L. 1987. Report of limnological research on Lake Annie. Report to the Archbold Biological Station, Lake Placid, Florida.

Battoe, L. E. and Lowe, E. F. 1992. Acidification of Lake Annie, Highlands Co., FL. Water, Air, and Soil Pollution. 65: 69-80.

Bergström, A. and Karlson, J. 2019. Light and nutrients control phytoplankton biomass responses to global change in northern lakes. Global Change Biology. 25(6). 2021-2029.

Bertilsson, S. and Tranvik, L. J. 2000. Photochemical transformation of dissolved organic matter in lakes. Limnology and Oceanography. 45(4): 753-762.

Bird, D. F. and Kalff, J. 1987. Algal phagotrophy: Regulating factors and importance relative to photosynthesis in Dinobryon (Chrysophyceae). Limnology and Oceanography. 32(2): 277-284.

Bishop, E. W. 1956. Geology and ground-water resources of Highlands County, Florida. Report of Investigations \#15, Florida Geological Survey, Tallahassee, FL. 
Canfield, D. E. Jr., Linda, S. B., and Hodgson, L. M. 1984. Relations between color and some limnological characteristics of Florida lakes. Journal of the American Water Resources Association. 20(3): 323-329.

Carey, C. C., Hanson, P. C., Lathrop, R. C., and St. Amand, A. L. 2016. Using wavelet analyses to examine variability in phytoplankton seasonal succession and annual periodicity. Journal of Plankton Research. 38(1): 27-40.

Carlson, R. E. and Simpson, J. 1996. A coordinator's guide to volunteer lake monitoring methods. North American Lake Management Society.

Clarke, K. R.and Gorley, R. N. 2015. Getting started with PRIMER v7. Plymouth: PRIMER-E Ltd.

Curtis, S. 2008. The Atlantic multidecadal oscillation and extreme daily precipitation over the U.S. and Mexico during the hurricane season. Climate Dynamics. 30: 343-351.

De Senerpont Domis, L. N., Elser, J. J., Gsell, A. S., Huszar, V. L. M., Ibelings, B. W., Jeppesen, E., Kosten, S., Mooij, W. M., Roland, F., Sommer, U., Van Donk, E., Winder, M., and Lürling, M. 2013. Plankton dynamics under different climatic conditions in space and time. Freshwater Biology. 58(3): 463-482.

De Wit, H. A., Valinia, S., Weyhenmeyer, G. A., Futter, M. N., Kortelainen, P., Austnes, K., Hessen, D. O., Räike, A., Laudon, H., and Vuorenmaa, J. 2016. Current browning of surface waters will be further promoted by wetter climate. Environmental Science and Technology Letters. 3(12): 430-435.

Enfield, D. B., Mestas-Nuñez, A. M., Trimble, P. J. 2001. The Atlantic multidecadal oscillation and its relation to rainfall and river flows in the continental U.S. Geophysical Research Letters. 28(10): 2077-2080.

Ficker, H. Luger, M., and Gassner, H. 2017. From dimictic to monomictic: Empirical evidence of thermal regime transitions in three deep alpine lakes in Austria induced by climate change. Freshwater Biology. 62(8): 1335-1345.

Findlay, D. L., Kasian, S. E. M., Stainton, M. P., Beaty, K., and Lyng, M. 2001. Climatic influences on algal populations of boreal forest lakes in the Experimental Lakes Area. Limnology and Oceanography. 46(7): 1784-1793.

Flanagan, C. M., McKnight, D. M., Liptzin, D., Williams, M. W., and Miller, M. P. 2009. Response of the phytoplankton community in an alpine lake to drought conditions: Colorado Rocky Mountain Front Range, U. S. A. Arctic, Antarctic, and Alpine Research. 41(2): 191-203. 
Florida LAKEWATCH. 2020. Florida LAKEWATCH water chemistry field sampling and laboratory protocols. Fischeries and Aquatic Sciences, School of Forest Resources and Conservation/IFAS, University of Florida.

Gaiser, E. E., Deyrup, N. D., Bachmann, R. W., Battoe, L. E., and Swain, H. M. 2009a. Effects of climate variability on transparency and thermal structure in subtropical, monomictic Lake Annie, Florida. Fundamental and Applied Limnology. 175(3): 217-230.

Gaiser, E. E., Deyrup, N. D., Bachmann, R. W., Battoe, L. E., and Swain, H. M. 2009b. Multidecadal climate oscillations detected in a transparency record from a subtropical Florida lake. Limnology and Oceanography. 54(6): 2228-2232.

Ghanbari, R. N. and Bravo, H. R. 2008. Coherence between atmospheric teleconnections, Great Lakes water levels, and regional climate. Advances in Water Resources. 31(10): 1284-1298.

Ghanbari, R. N., Bravo, H. R., Magnuson, J. J., Hyzer, W. G., and Benson, B. J. 2009. Coherence between lake ice cover, local climate and teleconnections (Lake Mendota, Wisconsin). Journal of Hydrology. 374(3-4): 282-293.

Hammer, Ø., Harper, D. A. T., and Ryan, P. D. 2001. PAST: Paleontological Statistics software package for education and data analysis. Palaeontologia Electronica 4(1): 9 pp.

Hanson, P. C., Hamilton, D. P., Stanley, E. H., Preston, N., Langman, O. C., and Kara, E. L. 2011. Fate of allochthonous dissolved organic carbon in lakes: A quantitative approach. PLoS ONE. 6(7): e21884.

Harris, G. P. and Baxter, G. 1996. Interannual variability in phytoplankton biomass and species composition in a subtropical reservoir. Freshwater Biology. 35: 545-560.

Havens, K. E. 1995. Secondary nitrogen limitation in a subtropical lake impacted by nonpoint source agriculture pollution. Environmental Pollution. 89(3): 241-246.

Hutchinson, G. E. 1961. The paradox of the plankton. The American Naturalist. 95(882): 137-145.

Irizarry-Ortiz, M. M., Obeysekera, J., Park, J., Trimble, P., Barnes, J., Park-Said, W., and Gadzinski, E. 2013. Historical trends in Florida temperature and precipitation. Hydrological Processes. 27(16): 2225-2246. 
Jansson, M., Bergström, A., Blomqvist, P., and Drakare, S. 2000. Allochthonous organic carbon and phytoplankton/bacterioplankton production relationships in lakes. Ecology. 81(11): 3250-3255.

Jennings, E., Jones, S., Arvola, L., Staehr, P. A., Gaiser, E., Jones, I. D., Weathers, K. C., Weyhenmeyer, G. A., Chiu, C. Y., and De Eyto, E. 2012. Effects of weatherrelated episodic events in lakes: an analysis based on high-frequency data. Freshwater Biology. 57(3): 589-601.

Jeppesen, E., Brucet, S., Naselli-Flores, L., Papastergiadou, E., Stefanidis, K., Nõges, T., Nõges, P., Attayde, J. L., Zohary, T., Coppens, J., Bucak, T., Menezes, R. F., Freitas, F. R. S., Kernan, M., Søndergaard, M., and Beklioğlu M. 2015. Ecological impacts of global warming and water abstraction on lakes and reservoirs due to changes in water level and related changes in salinity. Hydrobiologia. 750: 201-227.

Kamenir, Y., Dubinsky, Z., and Zohary, T. 2004. Phytoplankton size structure stability in a meso-eutrophic subtropical lake. Hydrobiologia. 520: 89-104.

Kelly, P. T., Solomon, C. T., Zwart, J. A., and Jones, S. E. 2018. A framework for understanding variation in pelagic gross primary production of lake ecosystems. Ecosystems. 21: 1364-1376.

Kiladis, G. N. and Diaz, H. F. 1989. Global climatic anomalies associated with extremes in the southern oscillation. Journal of Climate. 2(9): 1069-1090.

Klaveness, D. and Guillard R. R. L. 1975. The requirement for silicon in Synura petersenii (Chrysophyceae). Journal of Phycology. 11: 349-355.

Knight, J. R., Folland, C. K., and Scaife, A. A. 2006. Climate impacts of the Atlantic Multidecadal Oscillation. Geophysical Research Letter. 33(17).

Kritzberg, E. S., Maher Hasselquist, E., Šklerp, M., Löfgren, S., Olsson, O., Stadmark, J., Valinia, S., Hansson, L. A., and Laudon, H. 2020. Browning of freshwaters: consequences to ecosystem services, underlying drivers, and potential mitigation measures. Ambio. 49: 375-390.

Kruk, C., Huszar, V. L. M., Peeters, E. T. H. M., Bonilla, S., Costa, L., Lürling, M., Reynolds, C., and Scheffer, M. 2010. A morphological classification capturing functional variation in phytoplankton. Freshwater Biology. 55: 614-627.

Kruk, C., Peeters, E. T. H. M., Van Nes, E. H., Huszar, V. L. M., Costa, L. S., and Scheffer, M. 2011. Phytoplankton community composition can be predicted best in terms of morphological groups. Limnology and Oceanography. 56(1): 110-118. 
Kurtzman \& Scanlon 2007 - El Nino-Southern Oscillation and Pacific Decadal Oscillation impacts on precipitation in the southern and central United States: Evaluation of spatial distribution and predictions

Litchman, E., Klausmeier, C. A., Schofield, O. M., and Falkowski P. G. 2007. The role of functional traits and trade-offs in structuring phytoplankton communities: Scaling from cellular to ecosystem level. Ecology Letters. 10(12): 1170-1181.

Lydén, A. and Grahn, O. 1985. Phytoplankton species composition, biomass, and production in Lake Gårdsjõn - an acidified clearwater lake in SW Sweden. Ecological Bulletins. 37: 195-202.

Mantua, N. J. and Hare, S. R. 2002. The Pacific decadal oscillation. Journal of Oceanography. 58: 35-44.

Meyer-Jacob, C., Michelutti, N., Paterson, A. M., Cumming, B. F., Keller, W., and Smol, J. P. 2019. The browning and re-browning of lakes: Divergent lake-water organic carbon trends linked to acid deposition and climate change. Scientific Reports. 9: 16676.

Mills, C. M. and Walsh, J. E. 2013. Seasonal variation and spatial patterns of the atmospheric component of the Pacific decadal oscillation. Journal of Climate. 26(5): 1575-1594.

Olson, C. R., Solomon, C. T., and Jones, S. E. 2020. Shifting limitation of primary production: experimental support for a new model in lake ecosystems. Ecology Letters. Online version.

O’Reilly, C. M., Sharma, S., Gray, D. K, Hampton, S. E., Read, J. S., Rowley, R. J., Schneider, P., Lenters, J. D., McIntyre, P. B., Kraemer, B. M., Weyhenmeyer, G. A., Straile, D., Dong, B., Adrian, R., Allan, M. G., Anneville, O., Arvola, L, Austin, J., Bailey, J. L., Baron, J. S., Brookes, J. D., de Eyto, D., Dokulil, M. T., Hamilton, D. P., Havens, K., Hetherington, A. L., Higgins, S. N., Hook, S., Izmest'eva, L. R., Joehnk, K. D., Kangur, K., Kasprzak, P., Kumagai, M., Kuuisto, E., Leshkevich, G., Livingstone, D. M., MacIntyre, S., May, L., Melack, J. M., Mueller-Navarra, D. C., Naumenko, M., Noges, P., Noges, T., North, R. P., Plisnier, P. D., Rigosi, A., Rimmer, A., Schindler, D. E., Schladow, S. G., Schmid, M., Schmidt, S. R., Silow, E., Soylu, M. E., Teubner, K., Verburg, P., Voutilainen, A., Watkinson, A., Williamson, C. E., and Zhang, G. 2015. Rapid and highly variable warming of lake surface waters around the globe. Geophysical Research Letters. 42(10): 773-781.

Pendergrass, A. G., Knutti, R., Lehner, F., Deser, C., and Sanderson, B. M. 2017. Precipitation variability increases in a warmer climate. Scientific Reports. 7: 17966. 
Pilla, R. M., Williamson, C. E., Zhang, J., Smyth, R. L., Lenters, J. D., Brentrup, J. A., Knoll, L. B., and Fisher, T. J. 2018. Browning-related decreases in water transparency lead to long-term increases in surface water temperature and thermal stratification in two small lakes. Journal of Geophysical Research: Biogeosciences. 123(5): 1651-1655.

Porter, K. G., Saunders, P. A., Haberyan, K. A., Macubbin, A. E., Jacobsen, T. R., and Hodson, R. E. 1996. Annual cycle of autotrophic and heterotrophic production in a small, monomictic Piedmont lake (Lake Oglethorpe): Analog for the effects of climate warming on dimictic lakes. Limnology and Oceanography. 41(5): 10411051.

R Core Team. 2019. R: A language and environment for statistical computing. R Foundation for Statistical Computing, Vienna, Austria. https://www.Rproject.org/

Reynolds, C. S. 1984. Phytoplankton periodicity: the interactions of form, function and environmental variability. Freshwater Biology. 14(2): 111-142.

Reynolds, C. S., Huszar, V., Kruk, C., Naselli-Flores, L., and Melo, S. 2002. Towards a functional classification of the freshwater phytoplankton. Journal of Plankton Research. 24(5): 417-428.

Rühland, K., Paterson, A. M., and Smol, J. P. 2008. Hemispheric-scale patterns of climate-related shifts in planktonic diatoms from North American and European lakes. Global Change Biology. 14(11): 2740-2754.

Rühland, K., Paterson, A. M., and Smol, J. P. 2015. Lake diatom responses to warming: reviewing the evidence. Journal of Paleolimnology. 54:1-35.

Sacks, L. A., Swancar, A., and Lee, T. M., 1998. Estimating ground-water exchange with lakes using water-budget and chemical mass-balance approaches for ten lakes in the ridge areas of Polk and Highlands Counties, Florida. U. S. Geological Survey Water Resources Investigations Report 98: 4133. Tallahasee, FL.

Salmaso, N., Naselli-Flores, L., and Padisák, J. 2014. Functional classifications and their application in phytoplankton ecology. Freshwater Biology. 60(4): 603-619.

Sandgren, C. D., Hall, S. A., and Barlow, S. B. 1996. Siliceous scale production in Chrysophyte and Synurophyte algae. 1. Effects of silica-limited growth on cell silica content, scale morphology, and the construction of the scale layer of Synura petersenii. Journal of Phycology. 32: 675-692. 
Schindler, D. W., Curtis, P. J., Bayley, S. E., Parker, B. R., Beaty, K. G., and Stainton, M. P. 1997. Climate-induced changes in the dissolved organic carbon budgets of boreal lakes. Biogeochemistry. 36: 9-28.

Schmidt, N., Lipp, E. K., Rose, J. B., and Luther, M. E. 2001. ENSO influences on seasonal rainfall and river discharge in Florida. Journal of Climate. 14(4): 615628.

Segura, A. M., Kruk, C., Calliari, D., and Fort, H. 2012. Use of a morphology-based functional approach to model phytoplankton community succession in a shallow subtropical lake. Freshwater Biology. 58(3): 504-512.

Sharma, S., Blagrave, K., Magnuson, J. J., O’Reilly, C. M., Oliver, S., Batt, R. D., Magee, M. R., Straile, D., Weyhenmeyer, G. A., Winslow, L., and Woolway, R. L. 2019. Widespread loss of lake ice around the Northern Hemisphere in a warming world. Nature Climate Change. 9: 227-231.

Solomon, C. T., Jones, S. E., Weidel, B. C., Buffam, I., Fork, M. L., Karlsson, J., Larsen, S., Lennon, J. T., Read, J. S., Sadro, S., and Saros, J. E. 2015. Ecosystem consequences of changing inputs of terrestrial dissolved organic matter to lakes: current knowledge and future challenges. Ecosystems. 18: 376-389.

Sommer, U., Gliwicz, Z. M., Lampert, W., and Duncan, A. 1986. The PEG-model of seasonal succession of planktonic events in fresh waters. Archiv fur Hydrobiologie. 106(4): 433-471.

Sommer, U., Adrian, R., De Senerpont Domis, L., Elser, J. J., Gaedke, U., Ibelings, B., Jeppesen, E., Lürling, M., Molinero, J. C., Mooij, W. M., van Donk, E., and Winder, M. 2012. Beyond the Plankton Ecology Group (PEG) model: Mechanisms driving plankton succession. 43: 429-448.

Stauffer, R. 1991. Effects of citrus agriculture on ridge lakes in Central Florida. Water, Air, and Soil Pollution. 59: 125-144.

Stockwell, J. D., Doubek, J. P., Adrian, R., Anneville, O., Carey, C. C., Carvalho, L., de Senerpont Domis, L. N., Dur, G., Frassl, M. A., Grossart, H. P., Ibeling, B. W., Lajeunesse, M. J., Lewandowska, A. M., Llames, M. E., Matsuzaki, S. S., Nodine, E. R., Nõges, P., Patil, V. P., Pomati, F., Rinke, K., Rudstam, L. G., Rusak, J. A., Salmaso, N., Seltermann, C. T., Straile, D., Thackeray, S. J., Thiery, W., Urrutia-Cordero, P., Venail, P., Verburg, P., Woolway, R. I., Zohary, T., Andersen, M. R., Bhattacharya, R., Hejzlar, J., Janatian, N., Kpodonu, A. T. N. K., Williamson, T. J., and Wilson, H. L. 2020. Storm impacts on phytoplankton community dynamics in lakes. Global Change Biology. 26(5): 2756-2784. 
Straile, D. 2002. North Atlantic oscillation synchronizes food-web interactions in central European lakes. Proceedings of the Royal Society of Biological Sciences. 269(1489).

Swancar, A. 2005. Effect of El Niño Southern Oscillation weather patterns on Central Florida lake water budgets-lessons from Lake Starr. USGS Sciences in Florida. May. 36-38.

Thackeray, S. J., Jones, I. D., and Maberly, S. C. 2008. Long-term change in the phenology of spring phytoplankton: species-specific responses to nutrient enrichment and climate change. Journal of Ecology. 96(3): 523-535.

Tweed, S., Leblanc, M., and Cartwright, I. 2009. Groundwater-surface water interactions and the impact of a multi-year drought on lake conditions in SouthEast Australia. Journal of Hydrology. 379(1-2): 41-53.

Wehr, J. D. 1989. Experimental tests of nutrient limitation in freshwater picoplankton. Applied and Environmental Microbiology. 55(6): 1605-1661.

Weiss, K. C. B. and Ray, C. A. 2019. Unifying functional trait approaches to understand the assemblage of ecological communities: synthesizing taxonomic divides. Ecography. 42(12).

Weyhenmeyer, G. A. 2001. Warmer winters: are planktonic algal populations in Sweden's largest lakes affected? Ambio. 30(8): 565-571.

Wilken, S., Soares, M., Urrutia-Cordero, P., Ratcovich, J., Ekvall, M. K., Van Donk, E., and Hansson, L. A. 2017. Primary producers or consumers? Increasing phytoplankton bacterivory along a gradient of lake warming and browning. Limnology and Oceanography. 63(S1): S142-S155.

Winder, M. and Schindler, D. E. 2004. Climate effects on the phenology of lake processes. Global Change Biology. 10(11): 1844-1856.

Winder, M. and Sommer, U. 2012. Phytoplankton response to a changing climate. Hydrobiologia. 698: 5-16.

Winslow, L., Read, J., Woolway, R., Brentrup, J., Leach, T., Zwart, J., Albers, S., and Collinge, D. 2019. rLakeAnalyzer: Lake Physics Tools. R package version 1.11.4.1. https://CRAN.R-project.org/package=rLakeAnalyzer

Woolway, R. I. and Merchant, C. J. 2019. Worldwide alteration of lake mixing regimes in response to climate change. Nature Geoscience. 12: 271-276. 
Woolway, R. I., Kraemer, B. M., Lenters, J. D., Merchant, C. J., O'Reilly, C. M., and Sharma, S. 2020. Global lake responses to climate change. Nature Reviews Earth \& Environment. 1: 388-403.

Zhang, L. and Delworth, T. L. 2016. Simulated response of the Pacific decadal oscillation to climate change. Journal of Climate. 29(16): 5999-6018. 
Table 1: Mean \pm standard error (SE) of physicochemical variables for the dark (PCU > 30) and clear (PCU < 30) phases. Dark phases 1 and 2 (January 2005 - October 2007 and October 2012 - December 2019) were grouped for comparisons with the clear phase (November 2007 -September 2012). P-values and t-scores for Welch's t-test are presented in the last column- * indicates a significant difference between groups ( $p$ $<0.05) ; t_{\text {crit }}=1.973$. Variables include Atlantic multidecadal oscillation index (AMO Index), Pacific decadal oscillation index (PDO Index), Southern Oscillation Index (SOI), precipitation as an end the month total (PPT), monthly mean ground water stage $(G W S)$, monthly mean lake water stage (LWS), Secchi disk depth, Photosynthetically active radiation (PAR) extinction rate, surface water total organic carbon (TOC), surface water dissolved organic carbon (DOC), surface water color (PCU), thermocline depth, Schmidt stability, oxycline depth, surface water $\mathrm{pH}$, surface water total phosphorus (TP), and surface water total nitrogen (TN).

\begin{tabular}{|c|c|c|c|c|c|c|}
\hline & \multirow{2}{*}{ Variable } & \multicolumn{2}{|c|}{ Dark 1 and 2} & \multicolumn{2}{|l|}{ Clear } & \multirow{2}{*}{$\begin{array}{c}\text { Dark x Clear } \\
\text { p-value (t-score) }\end{array}$} \\
\hline & & Mean \pm SE & $\mathbf{N}$ & Mean \pm SE & $\mathbf{N}$ & \\
\hline \multirow{6}{*}{$\frac{3}{0}$} & AMO Index & $0.18 \pm 0.01$ & 121 & $0.15 \pm 0.02$ & 59 & $0.160(1.41)$ \\
\hline & PDO Index & $-0.09 \pm 0.08$ & 121 & $-1.47 \pm 0.10$ & 59 & $<0.001 *(10.59)$ \\
\hline & SOI & $-0.06 \pm 0.07$ & 121 & $0.80 \pm 0.13$ & 59 & $<0.001 *(5.73)$ \\
\hline & PPT (cm) & $10.67 \pm 0.89$ & 121 & $10.13 \pm 1.19$ & 59 & $0.717(0.36)$ \\
\hline & GWS (m amsl) & $40.17 \pm 0.04$ & 121 & $38.97 \pm 0.04$ & 59 & $<0.001 *(20.49)$ \\
\hline & LWS (m amsl) & $33.71 \pm 0.01$ & 121 & $33.56 \pm 0.01$ & 59 & $<0.001 *(8.79)$ \\
\hline \multirow{5}{*}{ 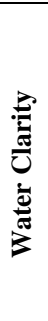 } & Secchi depth (m) & $1.76 \pm 0.06$ & 121 & $4.05 \pm 0.13$ & 59 & $<0.001 *(15.79)$ \\
\hline & Extinction rate $\left(\mathrm{K}_{\mathrm{d}} \mathrm{m}^{-1}\right)$ & $1.59 \pm 0.05$ & 113 & $0.75 \pm 0.02$ & 57 & $<0.001 *(14.33)$ \\
\hline & TOC $\left(\mathrm{mg} \mathrm{L}^{-1}\right)$ & $10.14 \pm 0.22$ & 113 & $6.27 \pm 0.12$ & 59 & $<0.001 *(15.20)$ \\
\hline & $\mathrm{DOC}\left(\mathrm{mg} \mathrm{L}^{-1}\right)$ & $10.37 \pm 0.25$ & 96 & $5.98 \pm 0.20$ & 46 & $<0.001 *(13.75)$ \\
\hline & Water Color (PCU) & $71.33 \pm 5.81$ & 58 & $13.46 \pm 0.95$ & 35 & $<0.001 *(9.83)$ \\
\hline \multirow{3}{*}{$\frac{\stackrel{\tilde{n}}{\underline{n}}}{\underline{\underline{E}}}$} & Thermocline depth (m) & $6.53 \pm 0.27$ & 121 & $7.93 \pm 0.36$ & 59 & $0.002 *(3.10)$ \\
\hline & Schmidt stability $\left(\mathrm{J} \mathrm{m}^{-2}\right)$ & $243.29 \pm 13.72$ & 121 & $258.35 \pm 23.00$ & 59 & $0.575(0.56)$ \\
\hline & Oxycline depth (m) & $13.93 \pm 0.50$ & 121 & $15.17 \pm 0.58$ & 59 & $0.106(1.63)$ \\
\hline \multirow{3}{*}{ 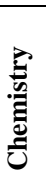 } & $\mathrm{pH}$ & $5.33 \pm 0.04$ & 116 & $5.00 \pm 0.08$ & 54 & $<0.001 *(3.53)$ \\
\hline & $\mathrm{TP}\left(\operatorname{ug} \mathrm{L}^{-1}\right)$ & $9.60 \pm 0.33$ & 121 & $5.66 \pm 0.21$ & 58 & $<0.001 *(10.07)$ \\
\hline & $\mathrm{TN}\left(\mathrm{mg} \mathrm{L}^{-1}\right)$ & $0.43 \pm 0.01$ & 121 & $0.29 \pm 0.01$ & 58 & $<0.001 *(9.30)$ \\
\hline
\end{tabular}


Table 2: Pearson correlation matrix of monthly physicochemical driver variables from January 2005 - December 2019. Bolded values indicate a correlation between two variables that is $<-0.5$ or $>0.5$ and statistically significant ( $p$ value <0.05). Variables include Atlantic multidecadal oscillation index (AMO Index), Pacific decadal oscillation index (PDO Index), Southern Oscillation Index (SOI), precipitation as an end the month total (PPT), monthly mean ground water stage (GWS), monthly mean lake water stage (LWS), Secchi disk depth, Photosynthetically active radiation (PAR) extinction rate, surface water total organic carbon (TOC), surface water dissolved organic carbon (DOC), surface water color (PCU), thermocline depth, Schmidt stability, oxycline depth, surface water $\mathrm{pH}$, surface water total phosphorus (TP), and surface water total nitrogen $(T N)$.

\begin{tabular}{|c|c|c|c|c|c|c|c|c|c|c|c|c|c|c|c|c|c|c|}
\hline & \multicolumn{6}{|c|}{ Hydrology } & \multicolumn{5}{|c|}{ Water Clarity } & \multicolumn{3}{|c|}{ Physics } & \multicolumn{3}{|c|}{ Chemistry } \\
\hline & & 3 & $\overrightarrow{0}$ & 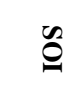 & $\bar{\nabla}$ & $\sum_{\infty}^{2}$ & $\sum_{\infty}^{5}$ & $\Xi \frac{\tilde{\sigma}}{\Omega}$ & $\overline{\mathrm{\theta}}$ & $\overrightarrow{0}$ & $\begin{array}{l}\bar{\delta} \\
\text { రి }\end{array}$ & $\widetilde{Z}$ & $\exists$ & 2 & $\vartheta$ & $\Xi$ & $\vec{\nabla}$ & Z \\
\hline \multirow{6}{*}{ 을 } & AMO & & & & & & & & & & & & & & & & & \\
\hline & PDO & 0.05 & & & & & & & & & & & & & & & & \\
\hline & SOI & -0.08 & -0.53 & & & & & & & & & & & & & & & \\
\hline & PPT & 0.33 & -0.04 & -0.07 & & & & & & & & & & & & & & \\
\hline & GWS & 0.13 & 0.52 & -0.28 & -0.16 & & & & & & & & & & & & & \\
\hline & LWS & 0.37 & 0.28 & -0.24 & 0.38 & 0.61 & & & & & & & & & & & & \\
\hline \multirow{5}{*}{ 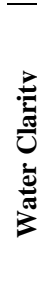 } & SECCHI & -0.08 & -0.48 & 0.28 & 0.11 & -0.82 & -0.56 & & & & & & & & & & & \\
\hline & KD & 0.14 & 0.34 & -0.26 & -0.08 & 0.80 & 0.66 & -0.82 & & & & & & & & & & \\
\hline & TOC & 0.24 & 0.38 & -0.28 & -0.03 & 0.77 & 0.60 & -0.81 & 0.84 & & & & & & & & & \\
\hline & DOC & 0.24 & 0.34 & -0.15 & -0.05 & 0.80 & 0.60 & -0.84 & 0.89 & 0.96 & & & & & & & & \\
\hline & $\mathbf{P C U}$ & 0.24 & 0.35 & -0.28 & -0.01 & 0.79 & 0.71 & -0.77 & 0.92 & 0.88 & 0.90 & & & & & & & \\
\hline \multirow{3}{*}{$\frac{\tilde{U}}{\tilde{D}}$} & TD & 0.10 & -0.25 & 0.12 & -0.06 & -0.08 & 0.11 & 0.11 & 0.04 & 0.05 & -0.09 & -0.05 & & & & & & \\
\hline & SS & 0.40 & -0.05 & -0.07 & 0.59 & -0.21 & 0.24 & 0.19 & -0.17 & -0.04 & -0.05 & -0.01 & -0.10 & & & & & \\
\hline & OD & -0.31 & -0.07 & 0.14 & -0.23 & -0.15 & -0.37 & $<0.00$ & -0.11 & -0.09 & -0.11 & -0.02 & -0.22 & -0.46 & & & & \\
\hline \multirow{3}{*}{ 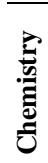 } & PH & 0.01 & -0.01 & 0.05 & -0.20 & 0.35 & 0.08 & -0.34 & 0.35 & 0.31 & 0.29 & 0.14 & \begin{tabular}{|l|}
0.09 \\
\end{tabular} & -0.32 & 0.10 & & & \\
\hline & TP & 0.24 & 0.31 & -0.31 & 0.07 & 0.62 & 0.64 & -0.59 & 0.64 & 0.62 & 0.59 & 0.74 & 0.03 & 0.02 & -0.07 & 0.13 & & \\
\hline & $\mathbf{T N}$ & 0.19 & 0.30 & -0.29 & -0.07 & 0.60 & 0.41 & -0.59 & 0.65 & 0.64 & 0.63 & 0.69 & -0.16 & -0.09 & -0.02 & 0.27 & 0.52 & \\
\hline
\end{tabular}


Table 3: Taxa identified in Lake Annie throughout the 14-year study period. Each taxon is also listed with their respective morphology-based functional group (MBFG), mean biovolume, mean relative cell density and biovolume for the dark and clear phases as percent contribution, and percent contribution to dissimilarity between phases.

\begin{tabular}{|c|c|c|c|c|c|c|c|c|c|}
\hline Phylum & Genus and species & Authority & MBFG & $\begin{array}{c}\text { Biovolume } \\
\left(\text { um }^{3}\right)\end{array}$ & $\begin{array}{c}\text { Dark Rel. } \\
\text { Mean } \\
\text { Cells (\%) }\end{array}$ & $\begin{array}{c}\text { Clear } \\
\text { Rel. } \\
\text { Mean } \\
\text { Cells }(\%)\end{array}$ & $\begin{array}{c}\text { Dark Rel. } \\
\text { Mean } \\
\text { Biovolume } \\
(\%)\end{array}$ & $\begin{array}{c}\text { Clear Rel. } \\
\text { Mean } \\
\text { Biovolume } \\
(\%)\end{array}$ & $\begin{array}{c}\text { Biovolume } \\
\% \\
\text { Contribution } \\
\text { to } \\
\text { Dissimilarity }\end{array}$ \\
\hline \multirow[t]{24}{*}{ Bacillariophyta } & Achnanthes chsp01 & Bory, 1822 & 6 & 484 & $0.00 \%$ & $0.00 \%$ & $0.00 \%$ & $0.01 \%$ & $0.01 \%$ \\
\hline & Achnanthes sp. & Bory, 1822 & 6 & 540 & $0.00 \%$ & $0.00 \%$ & $0.00 \%$ & $0.00 \%$ & $0.00 \%$ \\
\hline & Asterionella formosa & Hassall, 1850 & 6 & 213 & $4.26 \%$ & $0.32 \%$ & $1.48 \%$ & $0.16 \%$ & $1.15 \%$ \\
\hline & Aulacoseira herzogii & (Lemmermann) Simonsen, 1979 & 6 & 444 & $1.17 \%$ & $0.08 \%$ & $0.56 \%$ & $0.12 \%$ & $0.80 \%$ \\
\hline & Aulacoseira tenella & (Nygaard) Simonsen, 1979 & 6 & 90 & $0.21 \%$ & $0.01 \%$ & $0.01 \%$ & $0.01 \%$ & $0.12 \%$ \\
\hline & Aulacoseira coroniformis & Pearce \& Cremer, 2010 & 6 & 3601 & $0.04 \%$ & $0.02 \%$ & $0.16 \%$ & $0.15 \%$ & $0.25 \%$ \\
\hline & $\begin{array}{l}\text { Brachysira cf. } \\
\text { microcephala }\end{array}$ & (Grunow) Compère, 1986 & 6 & 314 & $0.08 \%$ & $0.03 \%$ & $0.05 \%$ & $0.02 \%$ & $0.16 \%$ \\
\hline & Brachysira neoexilis & Lange-Bertalot, 1994 & 6 & 283 & $0.00 \%$ & $0.00 \%$ & $0.00 \%$ & $0.00 \%$ & $0.01 \%$ \\
\hline & Brachysira serians & $\begin{array}{l}\text { (Brébisson) Round \& D.G. } \\
\text { Mann, } 1981\end{array}$ & & 2076 & $0.00 \%$ & $0.00 \%$ & $0.00 \%$ & $0.00 \%$ & $0.01 \%$ \\
\hline & Brachysira spp. & Kützing, 1836 & 6 & 276 & $0.00 \%$ & $0.00 \%$ & $0.00 \%$ & $0.00 \%$ & $0.01 \%$ \\
\hline & Encyonema cf. carina & $\begin{array}{l}\text { Lange-Bertalot \& Krammer, } \\
1997\end{array}$ & 6 & 1759 & $0.00 \%$ & $0.00 \%$ & $0.00 \%$ & $0.00 \%$ & $0.00 \%$ \\
\hline & $\begin{array}{l}\text { Encyonema } \\
\text { evergladianum }\end{array}$ & Krammer, 1997 & 6 & 353 & $0.00 \%$ & $0.00 \%$ & $0.00 \%$ & $0.00 \%$ & $0.01 \%$ \\
\hline & Encyonema lafc01 & Kützing, 1833 & 6 & 266 & $0.00 \%$ & $0.00 \%$ & $0.00 \%$ & $0.00 \%$ & $0.00 \%$ \\
\hline & Encyonema lafc02 & Kützing, 1833 & 6 & 265 & $0.00 \%$ & $0.00 \%$ & $0.00 \%$ & $0.00 \%$ & $0.00 \%$ \\
\hline & Encyonema spp. & Kützing, 1833 & 6 & 691 & $0.00 \%$ & $0.00 \%$ & $0.00 \%$ & $0.00 \%$ & $0.00 \%$ \\
\hline & Eunotia carolina & R.M. Patrick, 1958 & 6 & 440 & $0.00 \%$ & $0.00 \%$ & $0.00 \%$ & $0.00 \%$ & $0.04 \%$ \\
\hline & Eunotia diodon & Ehrenberg, 1837 & 6 & 924 & $0.00 \%$ & $0.00 \%$ & $0.00 \%$ & $0.00 \%$ & $0.01 \%$ \\
\hline & Eunotia flexиosa & $\begin{array}{l}\text { (Brébisson ex Kützing) Kützing, } \\
1849\end{array}$ & 6 & 12297 & $0.02 \%$ & $0.01 \%$ & $0.21 \%$ & $0.20 \%$ & $0.43 \%$ \\
\hline & Eunotia incisa (morph 2) & W. Smith ex W. Gregory, 1854 & 6 & 267 & $0.00 \%$ & $0.00 \%$ & $0.00 \%$ & $0.00 \%$ & $0.00 \%$ \\
\hline & $\begin{array}{l}\text { Eunotia lunaris v. } \\
\text { subarcuata }\end{array}$ & (Ehrenberg) Grunow, 1877 & 6 & 201 & $0.00 \%$ & $0.00 \%$ & $0.00 \%$ & $0.00 \%$ & $0.03 \%$ \\
\hline & Eunotia pectinalis & (Kützing) Rabenhorst, 1864 & 6 & 201 & $0.00 \%$ & $0.00 \%$ & $0.00 \%$ & $0.00 \%$ & $0.00 \%$ \\
\hline & $\begin{array}{l}\text { Eunotia rabenhorstiana } v \text {. } \\
\text { elongata }\end{array}$ & $\begin{array}{l}\text { (R.M. Patrick) Metzeltin \& } \\
\text { Lange-Bertalot, } 1998\end{array}$ & 6 & 5463 & $0.00 \%$ & $0.00 \%$ & $0.01 \%$ & $0.00 \%$ & $0.02 \%$ \\
\hline & Eunotia zasumiensis & (Cabejszekówna) Körner, 1970 & 6 & 140 & $4.63 \%$ & $0.00 \%$ & $1.03 \%$ & $0.00 \%$ & $0.91 \%$ \\
\hline & Eunotia spp. & Ehrenberg, 1837 & 6 & 3142 & $0.00 \%$ & $0.00 \%$ & $0.01 \%$ & $0.04 \%$ & $0.12 \%$ \\
\hline
\end{tabular}




\begin{tabular}{|c|c|c|c|c|c|c|c|c|c|}
\hline Phylum & Genus and species & Authority & MBFG & $\begin{array}{c}\text { Biovolume } \\
\left(\mathbf{u m}^{3}\right)\end{array}$ & $\begin{array}{l}\text { Dark Rel. } \\
\text { Mean } \\
\text { Cells (\%) }\end{array}$ & $\begin{array}{c}\text { Clear } \\
\text { Rel. } \\
\text { Mean } \\
\text { Cells }(\%) \\
\end{array}$ & $\begin{array}{c}\text { Dark Rel. } \\
\text { Mean } \\
\text { Biovolume } \\
(\%)\end{array}$ & $\begin{array}{c}\text { Clear Rel. } \\
\text { Mean } \\
\text { Biovolume } \\
(\%)\end{array}$ & $\begin{array}{c}\text { Biovolume } \\
\% \\
\text { Contribution } \\
\text { to } \\
\text { Dissimilarity }\end{array}$ \\
\hline \multirow[t]{27}{*}{ Bacillariophyta } & Frustulia crassinervia & $\begin{array}{l}\text { (Brébisson ex W. Smith) Lange- } \\
\text { Bertalot \& Krammer, } 1996\end{array}$ & 6 & 811 & $0.01 \%$ & $0.00 \%$ & $0.01 \%$ & $0.02 \%$ & $0.10 \%$ \\
\hline & $\begin{array}{l}\text { Frustulia } \\
\text { pseudomagaliesmontana }\end{array}$ & $\begin{array}{l}\text { K.E. Camburn \& D.F. Charles, } \\
2000\end{array}$ & 6 & 651 & $0.00 \%$ & $0.00 \%$ & $0.00 \%$ & $0.00 \%$ & $0.01 \%$ \\
\hline & Frustulia saxonica & Rabenhorst, 1853 & 6 & 8506 & $0.00 \%$ & $0.00 \%$ & $0.00 \%$ & $0.00 \%$ & $0.01 \%$ \\
\hline & Frustulia spp. & Rabenhorst, 1853 & 6 & 4760 & $0.00 \%$ & $0.00 \%$ & $0.02 \%$ & $0.00 \%$ & $0.04 \%$ \\
\hline & Fragilaria cf. sepes & Ehrenberg, 1854 & 6 & 130 & $0.33 \%$ & $0.00 \%$ & $0.03 \%$ & $0.00 \%$ & $0.07 \%$ \\
\hline & Iconella curvula & (W. Smith) Ruck \& Nakov, 2016 & 6 & 826 & $0.00 \%$ & $0.00 \%$ & $0.00 \%$ & $0.01 \%$ & $0.04 \%$ \\
\hline & Iconella cuspidata & $\begin{array}{l}\text { (Hustedt, 1942) D. Kapustin \& } \\
\text { Kulikovskiy, } 2018 \\
\text { (F.W. Lewis) Ruck \& Nakov, }\end{array}$ & 6 & 5273 & $0.00 \%$ & $0.00 \%$ & $0.01 \%$ & $0.00 \%$ & $0.01 \%$ \\
\hline & Iconella delicatissima & 2016 & 6 & 432 & $0.00 \%$ & $0.00 \%$ & $0.00 \%$ & $0.00 \%$ & $0.02 \%$ \\
\hline & Iconella linearis & (W. Smith) Ruck \& Nakov, 2016 & 6 & 7858 & $0.01 \%$ & $0.00 \%$ & $0.05 \%$ & $0.03 \%$ & $0.15 \%$ \\
\hline & $\begin{array}{l}\text { Iconella linearis } f \text {. } \\
\text { constricta }\end{array}$ & (W. Smith) Ruck \& Nakov, 2016 & 6 & 10996 & $0.01 \%$ & $0.00 \%$ & $0.09 \%$ & $0.02 \%$ & $0.15 \%$ \\
\hline & Lemnicola exigua & $\begin{array}{l}\text { (Grunow) Kulikovskiy, } \\
\text { Witkowski \& Plinski, } 2011\end{array}$ & 6 & 39 & $0.00 \%$ & $0.00 \%$ & $0.00 \%$ & $0.00 \%$ & $0.00 \%$ \\
\hline & $\begin{array}{l}\text { Mastogloia } \\
\text { cocconeiformis }\end{array}$ & Grunow, 1860 & 6 & 9102 & $0.00 \%$ & $0.00 \%$ & $0.02 \%$ & $0.09 \%$ & $0.15 \%$ \\
\hline & Mastogloia cf. lanceolata & Thwaites ex W. Smith, 1856 & 6 & 3519 & $0.00 \%$ & $0.00 \%$ & $0.00 \%$ & $0.00 \%$ & $0.01 \%$ \\
\hline & Navicula spp. & Bory de Saint-Vincent, 1822 & 6 & 714 & $0.00 \%$ & $0.00 \%$ & $0.00 \%$ & $0.00 \%$ & $0.02 \%$ \\
\hline & Neidium ampliatum & (Ehrenberg) Krammer, 1985 & 6 & 39684 & $0.00 \%$ & $0.00 \%$ & $0.09 \%$ & $0.18 \%$ & $0.18 \%$ \\
\hline & Neidium densestriatum & (Østrup) Krammer, 1985 & 6 & 6579 & $0.00 \%$ & $0.00 \%$ & $0.01 \%$ & $0.00 \%$ & $0.02 \%$ \\
\hline & Neidium spp. & Pfitzer, 1871 & 6 & 21991 & $0.00 \%$ & $0.00 \%$ & $0.02 \%$ & $0.00 \%$ & $0.02 \%$ \\
\hline & $\begin{array}{l}\text { Nitzschia cf. acidoclinata } \\
\text { Nitzschia cf. acidoclinata }\end{array}$ & Lange-Bertalot, 1976 & 6 & 123 & $0.00 \%$ & $0.00 \%$ & $0.00 \%$ & $0.00 \%$ & $0.01 \%$ \\
\hline & (large morph) & Lange-Bertalot, 1976 & 6 & 283 & $0.00 \%$ & $0.00 \%$ & $0.00 \%$ & $0.00 \%$ & $0.00 \%$ \\
\hline & Nitzschia gracilis & Hantzsch, 1860 & 6 & 1655 & $0.00 \%$ & $0.00 \%$ & $0.01 \%$ & $0.03 \%$ & $0.07 \%$ \\
\hline & Nitzschia paleacea & (Grunow) Grunow, 1881 & 6 & 75 & $0.00 \%$ & $0.00 \%$ & $0.00 \%$ & $0.00 \%$ & $0.01 \%$ \\
\hline & Nitzschia spp. & Hassall, 1845 & 6 & 799 & $0.01 \%$ & $0.00 \%$ & $0.00 \%$ & $0.00 \%$ & $0.02 \%$ \\
\hline & Pinnularia brauniana & (Grunow) Sudnicka, 1888 & 6 & 6240 & $0.00 \%$ & $0.00 \%$ & $0.00 \%$ & $0.05 \%$ & $0.10 \%$ \\
\hline & Pinnularia spp. & Ehrenberg, 1843 & 6 & 4516 & $0.02 \%$ & $0.00 \%$ & $0.07 \%$ & $0.02 \%$ & $0.14 \%$ \\
\hline & Tabellaria flocculosa & (Roth) Kützing, 1844 & 6 & 1934 & $0.06 \%$ & $0.03 \%$ & $0.09 \%$ & $0.24 \%$ & $0.44 \%$ \\
\hline & $\begin{array}{l}\text { Tabellaria flocculosa } v . \\
\text { linearis }\end{array}$ & J.D. Koppen, 1975 & 6 & 2389 & $0.76 \%$ & $0.00 \%$ & $1.49 \%$ & $0.00 \%$ & $1.25 \%$ \\
\hline & Thalassiosira spp. & Cleve, 1873 & 6 & 884 & $0.00 \%$ & $0.00 \%$ & $0.00 \%$ & $0.00 \%$ & $0.00 \%$ \\
\hline
\end{tabular}




\begin{tabular}{|c|c|c|c|c|c|c|c|c|c|}
\hline Phylum & Genus and species & Authority & MBFG & $\begin{array}{c}\text { Biovolume } \\
\left(\mathbf{u m}^{3}\right)\end{array}$ & $\begin{array}{l}\text { Dark Rel. } \\
\text { Mean } \\
\text { Cells }(\%) \\
\end{array}$ & $\begin{array}{c}\text { Clear } \\
\text { Rel. } \\
\text { Mean } \\
\text { Cells }(\%)\end{array}$ & $\begin{array}{c}\text { Dark Rel. } \\
\text { Mean } \\
\text { Biovolume } \\
(\%)\end{array}$ & $\begin{array}{c}\text { Clear Rel. } \\
\text { Mean } \\
\text { Biovolume } \\
(\%)\end{array}$ & $\begin{array}{c}\text { Biovolume } \\
\% \\
\text { Contribution } \\
\text { to } \\
\text { Dissimilarity }\end{array}$ \\
\hline \multirow[t]{23}{*}{ Bacillariophyta } & Urosolenia spp. & Round \& R.M. Crawford, 1990 & 6 & 3054 & $6.08 \%$ & $0.01 \%$ & $10.54 \%$ & $0.07 \%$ & $5.09 \%$ \\
\hline & $\begin{array}{l}\text { Urosolenia spp. (wide } \\
\text { morph) }\end{array}$ & \multirow{2}{*}{ Round \& R.M. Crawford, 1990} & 6 & 21405 & $3.92 \%$ & $0.01 \%$ & $2570 \%$ & $0.30 \%$ & $872 \%$ \\
\hline & Unknown girdle & & 6 & 3731 & $0.00 \%$ & $0.00 \%$ & $0.01 \%$ & $0.00 \%$ & $0.02 \%$ \\
\hline & $\begin{array}{l}\text { Actinotaenium cf. } \\
\text { rufescens } \\
\text { Bambusina brebissoniif. }\end{array}$ & (Cleve) Teiling, 1954 & 4 & 25956 & $0.00 \%$ & $0.00 \%$ & $0.00 \%$ & $0.09 \%$ & $0.09 \%$ \\
\hline & constricta & A.M. Scott \& Prescott, 1961 & 8 & 4280 & $0.00 \%$ & $0.40 \%$ & $0.00 \%$ & $3.76 \%$ & $1.03 \%$ \\
\hline & Closterium cf. angustatum & Kützing ex Ralfs, 1848 & 4 & 27635 & $0.00 \%$ & $0.00 \%$ & $0.01 \%$ & $0.00 \%$ & $0.03 \%$ \\
\hline & $\begin{array}{l}\text { Closterium angustatum } v . \\
\text { clavatum }\end{array}$ & Hastings, 1892 & 4 & 116031 & $0.00 \%$ & $0.00 \%$ & $0.02 \%$ & $0.00 \%$ & $0.02 \%$ \\
\hline & Closterium dianae & Ehrenberg ex Ralfs, 1848 & 4 & 6040 & $0.00 \%$ & $0.00 \%$ & $0.00 \%$ & $0.03 \%$ & $0.05 \%$ \\
\hline & Closterium ehrenbergii & Meneghini ex Ralfs, 1848 & 4 & 65973 & $0.00 \%$ & $0.00 \%$ & $0.14 \%$ & $0.00 \%$ & $0.00 \%$ \\
\hline & Closterium cf. gracile & Brébisson ex Ralfs, 1848 & 4 & 811 & $0.01 \%$ & $0.00 \%$ & $0.00 \%$ & $0.00 \%$ & $0.01 \%$ \\
\hline & $\begin{array}{l}\text { Closterium lineatum } v . \\
\text { africanum }\end{array}$ & (Schmidle) Willi Krieger, 1935 & 4 & 153938 & $0.00 \%$ & $0.00 \%$ & $0.00 \%$ & $0.49 \%$ & $0.21 \%$ \\
\hline & $\begin{array}{l}\text { Closterium cf. lineatum } v \text {. } \\
\text { elongatum }\end{array}$ & (Rosa) Croasdale, 1995 & 4 & 252 & $0.00 \%$ & $0.00 \%$ & $0.00 \%$ & $0.00 \%$ & $0.00 \%$ \\
\hline & Closterium parvulum & Nägeli, 1849 & 4 & 1178 & $0.00 \%$ & $0.00 \%$ & $0.00 \%$ & $0.00 \%$ & $0.01 \%$ \\
\hline & Closterium cf. planum & E.O. Hughes, 1952 & 4 & 16156 & $0.00 \%$ & $0.00 \%$ & $0.02 \%$ & $0.00 \%$ & $0.02 \%$ \\
\hline & Closterium setaceum & Ehrenberg ex Ralfs, 1848 & 4 & 6235 & $0.08 \%$ & $0.02 \%$ & $0.46 \%$ & $0.24 \%$ & $0.74 \%$ \\
\hline & $\begin{array}{l}\text { Closterium setaceum } v . \\
\text { elongatum }\end{array}$ & West \& G.S. West, 1905 & 4 & 1947 & $0.00 \%$ & $0.00 \%$ & $0.00 \%$ & $0.01 \%$ & $0.05 \%$ \\
\hline & $\begin{array}{l}\text { Closterium setaceum } v . \\
\text { vittatum }\end{array}$ & Grönblad, 1945 & 4 & 1323 & $0.00 \%$ & $0.01 \%$ & $0.00 \%$ & $0.01 \%$ & $0.03 \%$ \\
\hline & $\begin{array}{l}\text { Cosmarium contractum } v . \\
\text { ornatum }\end{array}$ & Kurt Förster, N.D. & 4 & 5163 & $0.01 \%$ & $0.14 \%$ & $0.04 \%$ & $1.22 \%$ & $1.15 \%$ \\
\hline & $\begin{array}{l}\text { Cosmarium margaritatum } \\
\text { f. minus }\end{array}$ & (Boldt) West \& G.S. West, 1897 & 4 & 6696 & $0.00 \%$ & $0.00 \%$ & $0.00 \%$ & $0.06 \%$ & $0.08 \%$ \\
\hline & $\begin{array}{l}\text { Cosmarium ocellatum } v . \\
\text { incrassatum }\end{array}$ & West \& G.S. West, 1897 & 4 & 2806 & $0.00 \%$ & $0.00 \%$ & $0.00 \%$ & $0.01 \%$ & $0.05 \%$ \\
\hline & $\begin{array}{l}\text { Cosmarium panamense } \\
\text { Cosmarium cf. }\end{array}$ & Prescott, 1936 & 4 & 115123 & $0.00 \%$ & $0.01 \%$ & $0.31 \%$ & $1.28 \%$ & $0.62 \%$ \\
\hline & $\begin{array}{l}\text { pseudotaxichondrum } v . \\
\text { scottii } \\
\text { Desmidium aptogonum } v .\end{array}$ & Kurt Förster, 1974 & 4 & 226 & $0.26 \%$ & $0.30 \%$ & $0.04 \%$ & $0.19 \%$ & $0.52 \%$ \\
\hline & constrictum & Brébisson ex Kützing, 1849 & 8 & 4220 & $0.00 \%$ & $0.00 \%$ & $0.01 \%$ & $0.00 \%$ & $0.02 \%$ \\
\hline
\end{tabular}




\begin{tabular}{|c|c|c|c|c|c|c|c|c|c|}
\hline Phylum & Genus and species & Authority & MBFG & $\begin{array}{c}\text { Biovolume } \\
\left(\mathbf{u m}^{3}\right)\end{array}$ & $\begin{array}{c}\text { Dark Rel. } \\
\text { Mean } \\
\text { Cells (\%) }\end{array}$ & $\begin{array}{c}\text { Clear } \\
\text { Rel. } \\
\text { Mean } \\
\text { Cells }(\%)\end{array}$ & $\begin{array}{c}\text { Dark Rel. } \\
\text { Mean } \\
\text { Biovolume } \\
(\%)\end{array}$ & $\begin{array}{c}\text { Clear Rel. } \\
\text { Mean } \\
\text { Biovolume } \\
(\%)\end{array}$ & $\begin{array}{c}\text { Biovolume } \\
\% \\
\text { Contribution } \\
\text { to } \\
\text { Dissimilarity }\end{array}$ \\
\hline \multirow[t]{27}{*}{ Charophyta } & $\begin{array}{l}\text { Desmidium baileyi } v . \\
\text { subcirculare }\end{array}$ & A.M. Scott \& Grönblad, N.D. & 8 & 2383 & $0.04 \%$ & $0.00 \%$ & $0.05 \%$ & $0.00 \%$ & $0.08 \%$ \\
\hline & $\begin{array}{l}\text { Desmidium } \\
\text { quadrangulatum }\end{array}$ & Ralfs ex Ralfs, 1848 & 8 & 27562 & $0.00 \%$ & $0.00 \%$ & $0.18 \%$ & $0.83 \%$ & $0.36 \%$ \\
\hline & Desmidium swartzii & C. Agardh ex Ralfs, 1848 & 8 & 18999 & $0.01 \%$ & $0.00 \%$ & $0.13 \%$ & $0.00 \%$ & $0.08 \%$ \\
\hline & Docidium cf. baculum & Brébisson ex Ralfs, 1848 & 4 & 10304 & $0.00 \%$ & $0.00 \%$ & $0.00 \%$ & $0.00 \%$ & $0.01 \%$ \\
\hline & $\begin{array}{l}\text { Docidium pleurotaenoides } \\
\text { Elakatothrix gelatinosa }\end{array}$ & $\begin{array}{l}\text { A.M. Scott \& Croasdale, } 1975 \\
\text { Wille, } 1898\end{array}$ & $\begin{array}{l}4 \\
1\end{array}$ & $\begin{array}{c}7813 \\
27\end{array}$ & $\begin{array}{l}0.00 \% \\
0.11 \%\end{array}$ & $\begin{array}{l}0.00 \% \\
0.20 \%\end{array}$ & $\begin{array}{l}0.01 \% \\
0.00 \%\end{array}$ & $\begin{array}{l}0.00 \% \\
0.02 \%\end{array}$ & $\begin{array}{l}0.01 \% \\
0.15 \%\end{array}$ \\
\hline & Euastrum informe & O.F. Borge, 1925 & 4 & 1734 & $0.00 \%$ & $0.00 \%$ & $0.01 \%$ & $0.00 \%$ & $0.03 \%$ \\
\hline & Euastrum intermedium & Cleve, 1864 & 4 & 16307 & $0.00 \%$ & $0.00 \%$ & $0.01 \%$ & $0.13 \%$ & $0.02 \%$ \\
\hline & $\begin{array}{l}\text { Euastrum ventricosum } v . \\
\text { rectangulare }\end{array}$ & Prescott \& A.M. Scott, 1945 & 4 & 57696 & $0.00 \%$ & $0.00 \%$ & $0.00 \%$ & $0.16 \%$ & $0.11 \%$ \\
\hline & $\begin{array}{l}\text { Euastrum wollei } v \text {. } \\
\text { pearlingtonense }\end{array}$ & Prescott \& A.M. Scott, N.D. & 4 & 267825 & $0.00 \%$ & $0.01 \%$ & $0.00 \%$ & $1.53 \%$ & $0.67 \%$ \\
\hline & $\begin{array}{l}\text { Gonatozygon cf. } \\
\text { aculeatum }\end{array}$ & W.N. Hastings, 1892 & 8 & 1774 & $0.00 \%$ & $0.00 \%$ & $0.00 \%$ & $0.01 \%$ & $0.05 \%$ \\
\hline & $\begin{array}{l}\text { Groenbladia bourrellyi v. } \\
\text { elongata }\end{array}$ & $\begin{array}{l}\text { (A.M. Scott \& Grönblad) Coesel, } \\
1998\end{array}$ & 8 & 1909 & $0.01 \%$ & $0.05 \%$ & $0.01 \%$ & $0.19 \%$ & $0.30 \%$ \\
\hline & Groenbladia neglecta & Teiling, 1952 & 8 & 4400 & $0.63 \%$ & $0.23 \%$ & $1.30 \%$ & $2.17 \%$ & $1.67 \%$ \\
\hline & Groenbladia taylorii & Scott \& Grönblad, 1957 & 8 & 1795 & $0.23 \%$ & $0.03 \%$ & $0.29 \%$ & $0.04 \%$ & $0.40 \%$ \\
\hline & Groenbladia undulata & (Nordstedt) Kurt Förster, 1973 & 8 & 235 & $0.10 \%$ & $0.04 \%$ & $0.02 \%$ & $0.02 \%$ & $0.12 \%$ \\
\hline & Hyalotheca dissiliens & Brébisson ex Ralfs, 1848 & 8 & 4095 & $0.12 \%$ & $0.00 \%$ & $0.41 \%$ & $0.00 \%$ & $0.16 \%$ \\
\hline & Micrasterias foliacea & Bailey ex Ralfs, 1848 & 4 & 55310 & $0.00 \%$ & $0.00 \%$ & $0.28 \%$ & $0.00 \%$ & $0.08 \%$ \\
\hline & Micrasterias johnsonii & West \& G.S. West, 1898 & 4 & 81156 & $0.00 \%$ & $0.00 \%$ & $0.18 \%$ & $0.00 \%$ & $0.07 \%$ \\
\hline & $\begin{array}{l}\text { Micrasterias radiata } f \text {. } \\
\text { parallela }\end{array}$ & Prescott \& A.M. Scott, 1952 & 4 & 36868 & $0.01 \%$ & $0.00 \%$ & $0.30 \%$ & $0.00 \%$ & $0.22 \%$ \\
\hline & Mougeotia sp. XSM & C. Agardh, 1824 & 8 & 1257 & $4.71 \%$ & $0.01 \%$ & $1.68 \%$ & $0.01 \%$ & $0.95 \%$ \\
\hline & Mougeotia sp. SM & C. Agardh, 1824 & 8 & 5027 & $0.26 \%$ & $0.13 \%$ & $0.18 \%$ & $0.23 \%$ & $0.53 \%$ \\
\hline & Mougeotia sp. MD & C. Agardh, 1824 & 8 & 13273 & $0.23 \%$ & $0.25 \%$ & $0.73 \%$ & $1.02 \%$ & $1.15 \%$ \\
\hline & Mougeotia sp. $L G$ & C. Agardh, 1824 & 8 & 25447 & $0.01 \%$ & $0.62 \%$ & $0.11 \%$ & $8.06 \%$ & $3.02 \%$ \\
\hline & Mougeotia sp. XL & C. Agardh, 1824 & 8 & 49087 & $0.02 \%$ & $0.11 \%$ & $0.30 \%$ & $6.06 \%$ & $2.30 \%$ \\
\hline & Mougeotia sp. XXL & C. Agardh, 1824 & 8 & 96211 & $0.00 \%$ & $0.01 \%$ & $0.10 \%$ & $0.27 \%$ & $0.21 \%$ \\
\hline & $\begin{array}{l}\text { Pleurotaenium trochiscum } \\
\text { Sphaerozosma laeve }\end{array}$ & $\begin{array}{l}\text { West \& G.S. West, } 1896 \\
\text { (Nordstedt) Thomasson, } 1957\end{array}$ & $\begin{array}{l}4 \\
8\end{array}$ & $\begin{array}{c}8680 \\
90\end{array}$ & $\begin{array}{l}0.00 \% \\
0.02 \%\end{array}$ & $\begin{array}{l}0.00 \% \\
0.00 \%\end{array}$ & $\begin{array}{l}0.02 \% \\
0.00 \%\end{array}$ & $\begin{array}{l}0.00 \% \\
0.00 \%\end{array}$ & $\begin{array}{l}0.02 \% \\
0.01 \%\end{array}$ \\
\hline & Spirogyra sp. & Link, 1820 & 8 & 70686 & $0.00 \%$ & $0.00 \%$ & $0.16 \%$ & $0.00 \%$ & $0.07 \%$ \\
\hline & Spondylosium planum & (Wolle) West \& G.S. West, 1912 & 8 & 983 & $0.08 \%$ & $0.02 \%$ & $0.09 \%$ & $0.03 \%$ & $0.19 \%$ \\
\hline
\end{tabular}




\begin{tabular}{|c|c|c|c|c|c|c|c|c|c|}
\hline Phylum & Genus and species & Authority & MBFG & $\underset{\left(\mathbf{u m}^{3}\right)}{\text { Biovolume }}$ & $\begin{array}{c}\text { Dark Rel. } \\
\text { Mean } \\
\text { Cells }(\%) \\
\end{array}$ & $\begin{array}{c}\text { Clear } \\
\text { Rel. } \\
\text { Mean } \\
\text { Cells }(\%) \\
\end{array}$ & $\begin{array}{c}\text { Dark Rel. } \\
\text { Mean } \\
\text { Biovolume } \\
(\%)\end{array}$ & $\begin{array}{c}\text { Clear Rel. } \\
\text { Mean } \\
\text { Biovolume } \\
(\%)\end{array}$ & $\begin{array}{c}\text { Biovolume } \\
\% \\
\text { Contribution } \\
\text { to } \\
\text { Dissimilarity } \\
\end{array}$ \\
\hline \multirow[t]{23}{*}{ Charophyta } & Staurastrum cf. anatinum & Cooke \& Wills, 1881 & 4 & 3757 & $0.00 \%$ & $0.00 \%$ & $0.00 \%$ & $0.00 \%$ & $0.02 \%$ \\
\hline & $\begin{array}{l}\text { Staurastrum cf. } \\
\text { ankyroides }\end{array}$ & Wolle, 1884 & 4 & 11543 & $0.03 \%$ & $0.00 \%$ & $0.37 \%$ & $0.03 \%$ & $0.40 \%$ \\
\hline & Staurastrum arachne & Ralfs ex Ralfs, 1848 & 4 & 2026 & $0.00 \%$ & $0.00 \%$ & $0.00 \%$ & $0.00 \%$ & $0.01 \%$ \\
\hline & $\begin{array}{l}\text { Staurastrum arachne } v . \\
\text { gyrans } \\
\text { Staurastrum brachiatum }\end{array}$ & $\begin{array}{l}\text { (L.N. Johnson) A.M. Scott \& } \\
\text { Grönblad, } 1957 \\
\text { Ralfs ex Ralfs. } 1848\end{array}$ & $\begin{array}{l}4 \\
4\end{array}$ & $\begin{array}{l}1806 \\
3569\end{array}$ & $\begin{array}{l}0.01 \% \\
0.01 \%\end{array}$ & $\begin{array}{l}0.00 \% \\
0.00 \%\end{array}$ & $\begin{array}{l}0.01 \% \\
0.06 \%\end{array}$ & $\begin{array}{l}0.01 \% \\
0.00 \%\end{array}$ & $\begin{array}{l}0.07 \% \\
0.07 \%\end{array}$ \\
\hline & $\begin{array}{l}\text { Staurastrum cf. } \\
\text { brachioprominens } v . \\
\text { africanum }\end{array}$ & P. Bourrelly, N.D. & 4 & 5030 & $0.00 \%$ & $0.08 \%$ & $0.00 \%$ & $0.95 \%$ & $0.97 \%$ \\
\hline & Staurastrum cerastes & P. Lundell, 1871 & 4 & 14683 & $0.00 \%$ & $0.01 \%$ & $0.04 \%$ & $0.29 \%$ & $0.33 \%$ \\
\hline & Staurastrum cingulum & $\begin{array}{l}\text { (West \& G.S. West) G.M. Smith, } \\
1922\end{array}$ & 4 & 8812 & $0.04 \%$ & $0.02 \%$ & $0.26 \%$ & $0.45 \%$ & $0.41 \%$ \\
\hline & Staurastrum comptum & Wolle, N.D. & 4 & 2327 & $0.00 \%$ & $0.01 \%$ & $0.01 \%$ & $0.06 \%$ & $0.13 \%$ \\
\hline & Staurastrum cyathipes & Scott \& Grönblad, 1957 & 4 & 5593 & $0.00 \%$ & $0.00 \%$ & $0.00 \%$ & $0.00 \%$ & $0.01 \%$ \\
\hline & $\begin{array}{l}\text { Staurastrum cf. } \\
\text { cyclofurcatum }\end{array}$ & A.M. Scott \& Grönblad, 1957 & 4 & 1014 & $0.00 \%$ & $0.01 \%$ & $0.00 \%$ & $0.01 \%$ & $0.02 \%$ \\
\hline & $\begin{array}{l}\text { Staurastrum diacanthum } \\
\text { v. evolutum }\end{array}$ & Scott \& Grönblad, 1957 & 4 & 285 & $0.00 \%$ & $0.00 \%$ & $0.00 \%$ & $0.00 \%$ & $0.01 \%$ \\
\hline & Staurastrum cf. gracile & Ralfs ex Ralfs, 1848 & 4 & 1248 & $0.00 \%$ & $0.00 \%$ & $0.00 \%$ & $0.00 \%$ & $0.01 \%$ \\
\hline & Staurastrum grallatorium & Nordstedt, 1870 & 4 & 1922 & $0.01 \%$ & $0.02 \%$ & $0.04 \%$ & $0.05 \%$ & $0.25 \%$ \\
\hline & Staurastrum hystrix & Ralfs, 1848 & 4 & 179 & $0.00 \%$ & $0.00 \%$ & $0.00 \%$ & $0.00 \%$ & $0.01 \%$ \\
\hline & $\begin{array}{l}\text { Staurastrum hystrix } v \text {. } \\
\text { floridense }\end{array}$ & A.M. Scott \& Grönblad, 1957 & 4 & 2183 & $0.00 \%$ & $0.00 \%$ & $0.00 \%$ & $0.00 \%$ & $0.01 \%$ \\
\hline & Staurastrum inconspicuum & Nordstedt, 1873 & 4 & 388 & $0.00 \%$ & $0.01 \%$ & $0.00 \%$ & $0.02 \%$ & $0.07 \%$ \\
\hline & $\begin{array}{l}\text { Staurastrum cf. johnsonii } \\
\text { v. depauperatum } \\
\text { Staurastrum leptocladum }\end{array}$ & $\begin{array}{l}\text { G.M. Smith, } 1924 \\
\text { Nordstedt, } 1870\end{array}$ & $\begin{array}{l}4 \\
4\end{array}$ & $\begin{array}{l}1670 \\
3993\end{array}$ & $\begin{array}{l}0.01 \% \\
0.01 \%\end{array}$ & $\begin{array}{l}0.00 \% \\
0.00 \%\end{array}$ & $\begin{array}{l}0.00 \% \\
0.07 \%\end{array}$ & $\begin{array}{l}0.00 \% \\
0.00 \%\end{array}$ & $\begin{array}{l}0.01 \% \\
0.09 \%\end{array}$ \\
\hline & Staurastrum leptocladum & & & & & & & & \\
\hline & v. sinuatum & Wolle, 1883 & 4 & 2381 & $0.02 \%$ & $0.00 \%$ & $0.04 \%$ & $0.00 \%$ & $0.12 \%$ \\
\hline & Staurastrum leptopus & Willi Krieger, 1932 & 4 & 2701 & $0.01 \%$ & $0.01 \%$ & $0.02 \%$ & $0.04 \%$ & $0.15 \%$ \\
\hline & $\begin{array}{l}\text { Staurastrum longipes } \\
\text { Staurastrum longispinum }\end{array}$ & (Nordstedt) Teiling, 1946 & 4 & 1102 & $0.00 \%$ & $0.00 \%$ & $0.00 \%$ & $0.00 \%$ & $0.02 \%$ \\
\hline & v. praelongum & A.M. Scott \& Grönblad, N.D. & 4 & 143361 & $0.00 \%$ & $0.00 \%$ & $0.07 \%$ & $0.00 \%$ & $0.04 \%$ \\
\hline & Staurastrum minnesotense & Wolle, 1885 & 4 & 208073 & $0.00 \%$ & $0.00 \%$ & $0.15 \%$ & $0.00 \%$ & $0.06 \%$ \\
\hline
\end{tabular}




\begin{tabular}{|c|c|c|c|c|c|c|c|c|c|}
\hline Phylum & Genus and species & Authority & MBFG & $\begin{array}{c}\text { Biovolume } \\
\left(\mathbf{u m}^{3}\right)\end{array}$ & $\begin{array}{l}\text { Dark Rel. } \\
\text { Mean } \\
\text { Cells }(\%)\end{array}$ & $\begin{array}{c}\text { Clear } \\
\text { Rel. } \\
\text { Mean } \\
\text { Cells }(\%)\end{array}$ & $\begin{array}{l}\text { Dark Rel. } \\
\text { Mean } \\
\text { Biovolume } \\
(\%)\end{array}$ & $\begin{array}{l}\text { Clear Rel. } \\
\text { Mean } \\
\text { Biovolume } \\
(\%)\end{array}$ & $\begin{array}{c}\text { Biovolume } \\
\% \\
\text { Contribution } \\
\text { to } \\
\text { Dissimilarity }\end{array}$ \\
\hline \multirow[t]{21}{*}{ Charophyta } & $\begin{array}{l}\text { Staurastrum cf. natator } v . \\
\text { crassum }\end{array}$ & West \& G.S. West, N.D. & 4 & 1423 & $0.00 \%$ & $0.01 \%$ & $0.00 \%$ & $0.04 \%$ & $0.11 \%$ \\
\hline & $\begin{array}{l}\text { Staurastrum novae- } \\
\text { caesareae }\end{array}$ & Wolle, 1880 & 4 & 56167 & $0.04 \%$ & $0.09 \%$ & $0.91 \%$ & $9.93 \%$ & $4.37 \%$ \\
\hline & $\begin{array}{l}\text { Staurastrum } \\
\text { octoverrucosum }\end{array}$ & A.M. Scott \& Grönblad, 1957 & 4 & 2214 & $0.01 \%$ & $0.03 \%$ & $0.02 \%$ & $0.16 \%$ & $0.36 \%$ \\
\hline & Staurastrum ophiura & P. Lundell, 1871 & 4 & 12760 & $0.10 \%$ & $0.13 \%$ & $0.84 \%$ & $3.26 \%$ & $2.62 \%$ \\
\hline & Staurastrum pingue & Teiling, 1942 & 4 & 2422 & $0.00 \%$ & $0.00 \%$ & $0.00 \%$ & $0.00 \%$ & $0.01 \%$ \\
\hline & $\begin{array}{l}\text { Staurastrum pinnatum } v . \\
\text { reductum }\end{array}$ & Willi Krieger, N.D. & 4 & 2904 & $0.00 \%$ & $0.00 \%$ & $0.00 \%$ & $0.02 \%$ & $0.05 \%$ \\
\hline & $\begin{array}{l}\text { Staurastrum } \\
\text { pseudotetracerum }\end{array}$ & $\begin{array}{l}\text { (Nordstedt) West \& G.S. West, } \\
1895\end{array}$ & 4 & 208 & $0.00 \%$ & $0.00 \%$ & $0.00 \%$ & $0.00 \%$ & $0.00 \%$ \\
\hline & Staurastrum punctulatum & Brébisson, 1848 & 4 & 1024 & $0.00 \%$ & $0.00 \%$ & $0.00 \%$ & $0.00 \%$ & $0.01 \%$ \\
\hline & Staurastrum rectangulare & Borge, 1896 & 4 & 877 & $0.00 \%$ & $0.00 \%$ & $0.00 \%$ & $0.00 \%$ & $0.00 \%$ \\
\hline & Staurastrum rotula & Nordstedt, 1869 & 4 & 17204 & $0.02 \%$ & $0.01 \%$ & $0.39 \%$ & $0.26 \%$ & $0.61 \%$ \\
\hline & Staurastrum spiculosum & A.M. Scott \& Grönblad, 1957 & 4 & 3667 & $0.00 \%$ & $0.00 \%$ & $0.00 \%$ & $0.01 \%$ & $0.01 \%$ \\
\hline & Staurastrum tenuissimum & West \& G.S. West, 1895 & 4 & 271 & $0.01 \%$ & $0.04 \%$ & $0.00 \%$ & $0.03 \%$ & $0.17 \%$ \\
\hline & $\begin{array}{l}\text { Staurastrum tetracerum } \\
\text { Staurastrum cf. turgescens }\end{array}$ & Ralf ex Ralf, 1848 & 4 & 96 & $0.00 \%$ & $0.00 \%$ & $0.00 \%$ & $0.00 \%$ & $0.01 \%$ \\
\hline & v. sparsigranulatum & A.M. Scott \& Grönblad, 1957 & 4 & 569 & $0.00 \%$ & $0.00 \%$ & $0.00 \%$ & $0.01 \%$ & $0.04 \%$ \\
\hline & $\begin{array}{l}\text { Staurodesmus cuspidatus } \\
\text { v. divergens } \\
\text { Staurodesmus connatus } \\
\text { Staurodesmus extensus }\end{array}$ & $\begin{array}{l}\text { (Nordstedt) Coesel, } 2007 \\
\text { (P. Lundell) Thomasson, } 1960 \\
\text { (O.F. Andersson) Teiling, } 1948\end{array}$ & $\begin{array}{l}4 \\
4 \\
4\end{array}$ & $\begin{array}{l}200 \\
143 \\
445\end{array}$ & $\begin{array}{l}0.00 \% \\
0.00 \% \\
0.04 \%\end{array}$ & $\begin{array}{l}0.00 \% \\
0.00 \% \\
0.01 \%\end{array}$ & $\begin{array}{l}0.00 \% \\
0.00 \% \\
0.01 \%\end{array}$ & $\begin{array}{l}0.00 \% \\
0.00 \% \\
0.01 \%\end{array}$ & $\begin{array}{l}0.01 \% \\
0.01 \% \\
0.09 \%\end{array}$ \\
\hline & $\begin{array}{l}\text { Staurodesmus incus } v . \\
\text { indentatus } \\
\text { Staurodesmus maximus } v .\end{array}$ & $\begin{array}{l}\text { (West \& G.S. West) Coesel, } \\
2007\end{array}$ & 4 & 1392 & $0.02 \%$ & $0.03 \%$ & $0.04 \%$ & $0.14 \%$ & $0.33 \%$ \\
\hline & divergens & (Borge) Teiling, 1967 & 4 & 18390 & $0.06 \%$ & $0.01 \%$ & $0.69 \%$ & $0.10 \%$ & $0.46 \%$ \\
\hline & $\begin{array}{l}\text { Staurodesmus } c f \text {. } \\
\text { megacanthus }\end{array}$ & (P. Lundell) Thunmark, 1948 & 4 & 3960 & $0.11 \%$ & $0.00 \%$ & $0.34 \%$ & $0.00 \%$ & $0.24 \%$ \\
\hline & Staurodesmus octocornis & $\begin{array}{l}\text { (Ehrenberg ex Ralfs) Stastny, } \\
\text { Skaloud, \& Neustupa, } 2013\end{array}$ & 4 & 547 & $0.03 \%$ & $0.08 \%$ & $0.01 \%$ & $0.13 \%$ & $0.36 \%$ \\
\hline & $\begin{array}{l}\text { Staurodesmus triangularis } \\
\text { v. inflatus }\end{array}$ & (Lagerheim) Teiling, 1948 & 4 & 913 & $9.40 \%$ & $2.94 \%$ & $7.63 \%$ & $7.94 \%$ & $3.32 \%$ \\
\hline & $\begin{array}{l}\text { Xanthidium antilopaeum } \\
\text { v. americanum }\end{array}$ & A.M. Scott \& Grönblad, N.D. & 4 & 9125 & $0.00 \%$ & $0.01 \%$ & $0.00 \%$ & $0.20 \%$ & $0.00 \%$ \\
\hline
\end{tabular}




\begin{tabular}{|c|c|c|c|c|c|c|c|c|c|}
\hline Phylum & Genus and species & Authority & MBFG & $\begin{array}{c}\text { Biovolume } \\
\left(\mathbf{u m}^{3}\right)\end{array}$ & $\begin{array}{l}\text { Dark Rel. } \\
\text { Mean } \\
\text { Cells (\%) }\end{array}$ & $\begin{array}{c}\text { Clear } \\
\text { Rel. } \\
\text { Mean } \\
\text { Cells (\%) }\end{array}$ & $\begin{array}{c}\text { Dark Rel. } \\
\text { Mean } \\
\text { Biovolume } \\
(\%)\end{array}$ & $\begin{array}{c}\text { Clear Rel. } \\
\text { Mean } \\
\text { Biovolume } \\
(\%) \\
\end{array}$ & $\begin{array}{c}\text { Biovolume } \\
\% \\
\text { Contribution } \\
\text { to } \\
\text { Dissimilarity } \\
\end{array}$ \\
\hline \multirow[t]{6}{*}{ Charophyta } & $\begin{array}{l}\text { Xanthidium antilopaeum } f \text {. } \\
\text { javanicum } \\
\text { Xanthidium armatum }\end{array}$ & $\begin{array}{l}\text { (Nordstedt) Coesel, } 2007 \\
\text { Brébisson ex Ralfs, } 1848\end{array}$ & $\begin{array}{l}4 \\
4\end{array}$ & $\begin{array}{c}13366 \\
6656\end{array}$ & $\begin{array}{l}0.00 \% \\
0.00 \%\end{array}$ & $\begin{array}{l}0.00 \% \\
0.00 \%\end{array}$ & $\begin{array}{l}0.01 \% \\
0.01 \%\end{array}$ & $\begin{array}{l}0.08 \% \\
0.00 \%\end{array}$ & $\begin{array}{l}0.13 \% \\
0.02 \%\end{array}$ \\
\hline & $\begin{array}{l}\text { Xanthidium armatum } v . \\
\text { cervicorne }\end{array}$ & West \& G.S. West, 1898 & 4 & 249848 & $0.00 \%$ & $0.00 \%$ & $0.00 \%$ & $0.17 \%$ & $0.13 \%$ \\
\hline & $\begin{array}{l}\text { Xanthidium cristatum } v . \\
\text { scrobiculatum } f . \\
\text { papillatum }\end{array}$ & A.M. Scott \& Grönblad, N.D. & 4 & 20460 & $0.00 \%$ & $0.00 \%$ & $0.02 \%$ & $0.00 \%$ & $0.03 \%$ \\
\hline & Zygogonium zygospore & Kützing, 1843 & 4 & 385 & $0.00 \%$ & $0.00 \%$ & $0.00 \%$ & $0.01 \%$ & $0.04 \%$ \\
\hline & Unknown desmid filament & & 8 & 1284 & $0.00 \%$ & $0.00 \%$ & $0.00 \%$ & $0.00 \%$ & $0.01 \%$ \\
\hline & Unknown desmid & & 4 & 346 & $0.00 \%$ & $0.04 \%$ & $0.00 \%$ & $0.14 \%$ & $0.02 \%$ \\
\hline \multirow[t]{19}{*}{ Chlorophyta } & $\begin{array}{l}\text { Ankistrodesmus } c f . \\
\text { bernardii }\end{array}$ & Komárek, 1983 & 4 & 77 & $1.26 \%$ & $0.00 \%$ & $0.33 \%$ & $0.00 \%$ & $0.12 \%$ \\
\hline & Asterococcus sp. cf. & Scherffel, 1908 & 7 & 195 & $0.74 \%$ & $0.05 \%$ & $0.15 \%$ & $0.03 \%$ & $0.02 \%$ \\
\hline & Botryococcus sp. & Kützing, 1849 & 7 & 3084 & $0.08 \%$ & $0.11 \%$ & $0.30 \%$ & $0.95 \%$ & $0.22 \%$ \\
\hline & Botryococcus braunii & Kützing, 1849 & 7 & 247 & $1.57 \%$ & $2.46 \%$ & $0.32 \%$ & $1.25 \%$ & $1.56 \%$ \\
\hline & Bulbochaete sp. (lorica) & C. Agardh, 1817 & 8 & 884 & $0.00 \%$ & $0.00 \%$ & $0.00 \%$ & $0.00 \%$ & $1.05 \%$ \\
\hline & Chlamydomonas spp. & Ehrenberg, 1833 & 5 & 45 & $0.08 \%$ & $0.59 \%$ & $0.00 \%$ & $0.05 \%$ & $0.38 \%$ \\
\hline & Chlamydomonas fusus & Ettl, 1965 & 5 & 9 & $0.33 \%$ & $0.11 \%$ & $0.00 \%$ & $0.00 \%$ & $0.00 \%$ \\
\hline & Closteriopsis sp. & Lemmermann, 1899 & 4 & 115 & $0.21 \%$ & $0.00 \%$ & $0.02 \%$ & $0.00 \%$ & $0.24 \%$ \\
\hline & Coelastrum cruciatum & Schmidle, 1900 & 4 & 7776 & $0.00 \%$ & $0.01 \%$ & $0.00 \%$ & $0.09 \%$ & $0.08 \%$ \\
\hline & $\begin{array}{l}\text { Coelastrum pulchrum } v . \\
\text { cruciatum }\end{array}$ & (Kammerer) Komárek, 1983 & 4 & 13045 & $0.32 \%$ & $0.00 \%$ & $1.38 \%$ & $0.00 \%$ & $0.14 \%$ \\
\hline & $\begin{array}{l}\text { Cylindrocapsa cf. } \\
\text { geminella }\end{array}$ & Wolle, 1887 & 8 & 2190 & $0.02 \%$ & $0.00 \%$ & $0.01 \%$ & $0.00 \%$ & $0.12 \%$ \\
\hline & Eudorina spp. & Ehrenberg, 1832 & 5 & 24 & $0.14 \%$ & $0.07 \%$ & $0.00 \%$ & $0.00 \%$ & $0.70 \%$ \\
\hline & Eudorina elegans & Ehrenberg, 1832 & 5 & 18 & $0.03 \%$ & $0.00 \%$ & $0.00 \%$ & $0.00 \%$ & $0.01 \%$ \\
\hline & Golenkinia sp. $c f$. & Chodat, 1894 & 4 & 1758 & $0.00 \%$ & $0.00 \%$ & $0.01 \%$ & $0.01 \%$ & $0.01 \%$ \\
\hline & $\begin{array}{l}\text { Mucidosphaerium } \\
\text { sphagnale }\end{array}$ & $\begin{array}{l}\text { (Hindak) C. Bock, Proschold \& } \\
\text { Krienitz, } 2011\end{array}$ & 7 & 20 & $7.89 \%$ & $1.97 \%$ & $0.19 \%$ & $0.13 \%$ & $0.01 \%$ \\
\hline & $\begin{array}{l}\text { Mucidosphaerium } c f \text {. } \\
\text { pulchellum }\end{array}$ & $\begin{array}{l}\text { (H.C. Wood) C. Bock, Proschold } \\
\text { \& Krienitz, } 2011\end{array}$ & 7 & 92 & $0.19 \%$ & $0.00 \%$ & $0.01 \%$ & $0.00 \%$ & $0.05 \%$ \\
\hline & Nephrocytium cf. lunatum & West, 1892 & 7 & 80 & $0.62 \%$ & $0.00 \%$ & $0.07 \%$ & $0.00 \%$ & $0.58 \%$ \\
\hline & Oedogonium sp. SM & Link ex Hirn, 1900 & 8 & 1257 & $0.13 \%$ & $0.05 \%$ & $0.02 \%$ & $0.05 \%$ & $0.05 \%$ \\
\hline & Oedogonium sp. MD & Link ex Hirn, 1900 & 8 & 5027 & $0.14 \%$ & $0.04 \%$ & $0.14 \%$ & $0.12 \%$ & $0.13 \%$ \\
\hline
\end{tabular}




\begin{tabular}{|c|c|c|c|c|c|c|c|c|c|}
\hline Phylum & Genus and species & Authority & MBFG & $\begin{array}{c}\text { Biovolume } \\
\left(\mathbf{u m}^{3}\right)\end{array}$ & $\begin{array}{l}\text { Dark Rel. } \\
\text { Mean } \\
\text { Cells }(\%)\end{array}$ & $\begin{array}{c}\text { Clear } \\
\text { Rel. } \\
\text { Mean } \\
\text { Cells }(\%)\end{array}$ & $\begin{array}{c}\text { Dark Rel. } \\
\text { Mean } \\
\text { Biovolume } \\
(\%)\end{array}$ & $\begin{array}{c}\text { Clear Rel. } \\
\text { Mean } \\
\text { Biovolume } \\
(\%)\end{array}$ & $\begin{array}{c}\text { Biovolume } \\
\% \\
\text { Contribution } \\
\text { to } \\
\text { Dissimilarity }\end{array}$ \\
\hline \multirow[t]{30}{*}{ Charophyta } & Oedogonium sp. $L G$ & Link ex Hirn, 1900 & 8 & 12272 & $0.00 \%$ & $0.00 \%$ & $0.02 \%$ & $0.00 \%$ & $0.17 \%$ \\
\hline & Oocystis submarina & Lagerheim, 1886 & 7 & 17 & $0.76 \%$ & $2.09 \%$ & $0.01 \%$ & $0.08 \%$ & $0.38 \%$ \\
\hline & Oocystis sp. $L G$ & Nägeli ex A. Braun, 1855 & 7 & 169 & $0.08 \%$ & $0.00 \%$ & $0.01 \%$ & $0.00 \%$ & $0.02 \%$ \\
\hline & Oocystis sp. & Nägeli ex A. Braun, 1855 & 7 & 24 & $0.77 \%$ & $0.00 \%$ & $0.02 \%$ & $0.00 \%$ & $0.35 \%$ \\
\hline & Pandorina spp. & Bory, 1826 & 5 & 3783 & $0.00 \%$ & $0.00 \%$ & $0.01 \%$ & $0.00 \%$ & $0.05 \%$ \\
\hline & Pedinomonas sp. & Korshikov, 1923 & 5 & 10 & $0.00 \%$ & $0.00 \%$ & $0.00 \%$ & $0.00 \%$ & $0.08 \%$ \\
\hline & Planktosphaeria spp.cf. & G.M. Smith, 1918 & 1 & 8 & $0.54 \%$ & $1.12 \%$ & $0.00 \%$ & $0.03 \%$ & $0.00 \%$ \\
\hline & Planktosphaeria spp. 2 cf. & G.M. Smith, 1918 & 7 & 24 & $1.42 \%$ & $1.55 \%$ & $0.04 \%$ & $0.11 \%$ & $0.15 \%$ \\
\hline & Quadrigula cf. chodatii & $\begin{array}{l}\text { (Tanner-Füllermann) G.M. } \\
\text { Smith, } 1920\end{array}$ & 7 & 21 & $1.56 \%$ & $0.53 \%$ & $0.04 \%$ & $0.03 \%$ & $0.41 \%$ \\
\hline & Radiofilum sp. cf. & Schmidle, 1894 & 8 & 940 & $0.49 \%$ & $0.00 \%$ & $0.02 \%$ & $0.00 \%$ & $0.27 \%$ \\
\hline & Scenedesmus balatonicus & Hortobágyi, 1943 & 1 & 97 & $0.11 \%$ & $0.16 \%$ & $0.01 \%$ & $0.04 \%$ & $0.07 \%$ \\
\hline & Scenedesmus obtusus & Meyen, 1829 & 1 & 61 & $0.00 \%$ & $0.00 \%$ & $0.00 \%$ & $0.00 \%$ & $0.24 \%$ \\
\hline & Scenedesmus quadricauda & (Turpin) Brébisson, 1835 & 4 & 265 & $0.05 \%$ & $0.03 \%$ & $0.01 \%$ & $0.02 \%$ & $0.01 \%$ \\
\hline & Selenastrum sp. unicell & Reinsch, 1867 & 1 & 3 & $0.04 \%$ & $0.01 \%$ & $0.00 \%$ & $0.00 \%$ & $0.12 \%$ \\
\hline & Selenastrum cf. minutum & $\begin{array}{l}\text { (Nägeli) Collins, } 1907 \\
\text { Uherkovich \& A.W.F. Schmidt }\end{array}$ & 1 & 88 & $0.02 \%$ & $0.01 \%$ & $0.00 \%$ & $0.00 \%$ & $0.01 \%$ \\
\hline & Selenodictyon brasiliense & ex Comas \& Komárek, 1992 & 7 & 15 & $1.37 \%$ & $0.00 \%$ & $0.02 \%$ & $0.00 \%$ & $0.05 \%$ \\
\hline & Sphaerocystis sp. & Chodat, 1897 & 7 & 61 & $0.44 \%$ & $0.17 \%$ & $0.02 \%$ & $0.04 \%$ & $0.16 \%$ \\
\hline & Sphaerocystis sp. SM & Chodat, 1897 & 7 & 3 & $1.33 \%$ & $0.45 \%$ & $0.00 \%$ & $0.00 \%$ & $0.14 \%$ \\
\hline & Tetrachlorella alternans & (G.M. Smith) Korshikov, 1939 & 7 & 173 & $0.62 \%$ & $0.13 \%$ & $0.10 \%$ & $0.07 \%$ & $0.08 \%$ \\
\hline & Treubaria schmidlei & (Schröder) Fott \& Kovácik, 1975 & 1 & 28 & $0.00 \%$ & $0.00 \%$ & $0.00 \%$ & $0.00 \%$ & $0.42 \%$ \\
\hline & Treubaria setigera & (W. Archer) G.M. Smith, 1933 & 1 & 8 & $0.00 \%$ & $0.01 \%$ & $0.00 \%$ & $0.00 \%$ & $0.00 \%$ \\
\hline & SM green unicell & & 1 & 21 & $0.02 \%$ & $0.00 \%$ & $0.00 \%$ & $0.00 \%$ & $0.01 \%$ \\
\hline & MD green unicell & & 1 & 98 & $0.70 \%$ & $0.49 \%$ & $0.07 \%$ & $0.17 \%$ & $0.01 \%$ \\
\hline & LG green unicell & & 4 & 573 & $0.34 \%$ & $0.29 \%$ & $0.16 \%$ & $0.40 \%$ & $0.47 \%$ \\
\hline & $\begin{array}{l}\text { LG green unicell with } \\
\text { mucilage } \\
X L \text { green unicell }\end{array}$ & & $\begin{array}{l}4 \\
4\end{array}$ & $\begin{array}{c}573 \\
2651\end{array}$ & $\begin{array}{l}0.04 \% \\
0.08 \%\end{array}$ & $\begin{array}{l}0.00 \% \\
0.10 \%\end{array}$ & $\begin{array}{l}0.01 \% \\
0.16 \%\end{array}$ & $\begin{array}{l}0.00 \% \\
0.94 \%\end{array}$ & $\begin{array}{l}0.82 \% \\
0.07 \%\end{array}$ \\
\hline & XL green unicell with & & & & & & & & \\
\hline & mucilage & & 4 & 2651 & $0.01 \%$ & $0.00 \%$ & $0.06 \%$ & $0.00 \%$ & $0.82 \%$ \\
\hline & $X X L$ green unicell & & 4 & 50265 & $0.00 \%$ & $0.00 \%$ & $0.07 \%$ & $0.00 \%$ & $0.09 \%$ \\
\hline & Oval unicell & & 4 & 329 & $0.66 \%$ & $0.46 \%$ & $0.16 \%$ & $0.35 \%$ & $0.06 \%$ \\
\hline & Unknown green filament & & 8 & 37 & $0.00 \%$ & $0.00 \%$ & $0.00 \%$ & $0.00 \%$ & $0.79 \%$ \\
\hline Euglenophyta & Euglena spp. & Ehrenberg, 1830 & 5 & 31 & $0.00 \%$ & $0.00 \%$ & $0.00 \%$ & $0.00 \%$ & $0.00 \%$ \\
\hline
\end{tabular}




\begin{tabular}{|c|c|c|c|c|c|c|c|c|c|}
\hline Phylum & Genus and species & Authority & MBFG & $\begin{array}{c}\text { Biovolume } \\
\left(\mathbf{u m}^{3}\right)\end{array}$ & $\begin{array}{c}\text { Dark Rel. } \\
\text { Mean } \\
\text { Cells (\%) }\end{array}$ & $\begin{array}{c}\text { Clear } \\
\text { Rel. } \\
\text { Mean } \\
\text { Cells }(\%)\end{array}$ & $\begin{array}{l}\text { Dark Rel. } \\
\text { Mean } \\
\text { Biovolume } \\
(\%) \\
\end{array}$ & $\begin{array}{c}\text { Clear Rel. } \\
\text { Mean } \\
\text { Biovolume } \\
(\%) \\
\end{array}$ & $\begin{array}{c}\text { Biovolume } \\
\% \\
\text { Contribution } \\
\text { to } \\
\text { Dissimilarity } \\
\end{array}$ \\
\hline \multirow{3}{*}{ Euglenophyta } & Phacus spp. & Dujardin, 1841 & 5 & 1319 & $0.00 \%$ & $0.00 \%$ & $0.00 \%$ & $0.01 \%$ & $0.03 \%$ \\
\hline & Trachelomonas sp. (red) & Ehrenberg, 1834 & 5 & 1702 & $0.00 \%$ & $0.00 \%$ & $0.01 \%$ & $0.01 \%$ & $0.05 \%$ \\
\hline & $\begin{array}{l}\text { Trachelomonas sp. } \\
\text { (green) } \\
\text { Lg Euglenoid }\end{array}$ & Ehrenberg, 1834 & $\begin{array}{l}5 \\
5\end{array}$ & $\begin{array}{c}686 \\
89868\end{array}$ & $\begin{array}{l}0.00 \% \\
0.00 \%\end{array}$ & $\begin{array}{l}0.00 \% \\
0.00 \%\end{array}$ & $\begin{array}{l}0.00 \% \\
0.08 \%\end{array}$ & $\begin{array}{l}0.00 \% \\
0.00 \%\end{array}$ & $\begin{array}{l}0.01 \% \\
0.04 \%\end{array}$ \\
\hline \multirow[t]{2}{*}{ Cryptophyta } & Cryptomonas spp. & Ehrenberg, 1831 & 5 & 464 & $0.07 \%$ & $0.08 \%$ & $0.04 \%$ & $0.08 \%$ & $0.34 \%$ \\
\hline & Cryptomonas spp. $L G$ & Ehrenberg, 1831 & 5 & 2529 & $0.01 \%$ & $0.01 \%$ & $0.02 \%$ & $0.04 \%$ & $0.17 \%$ \\
\hline \multirow[t]{14}{*}{ Ochrophyta } & Crysophyte cyst & & 2 & 867 & $0.00 \%$ & $0.00 \%$ & $0.00 \%$ & $0.00 \%$ & $0.01 \%$ \\
\hline & Dinobryon acuminatum & Ruttner, 1913 & 2 & 29 & $0.00 \%$ & $0.00 \%$ & $0.00 \%$ & $0.00 \%$ & $0.01 \%$ \\
\hline & Dinobryon bavaricum & Imhof, 1890 & 2 & 118 & $0.48 \%$ & $1.19 \%$ & $0.11 \%$ & $0.61 \%$ & $0.35 \%$ \\
\hline & Dinobryon crenulatum & West \& G.S. West, 1909 & 2 & 189 & $0.07 \%$ & $0.48 \%$ & $0.01 \%$ & $0.22 \%$ & $0.47 \%$ \\
\hline & Dinobryon cylindricum & O.E. Imhof, 1887 & 2 & 220 & $0.05 \%$ & $2.47 \%$ & $0.01 \%$ & $2.46 \%$ & $0.36 \%$ \\
\hline & Gonyostomum semen & (Ehrenberg) Diesing, 1866 & 5 & 38738 & $0.02 \%$ & $0.00 \%$ & $0.59 \%$ & $0.46 \%$ & $0.71 \%$ \\
\hline & Lagynion cf. ampullaceum & (A. Stokes) Pascher, 1912 & 2 & 65 & $0.02 \%$ & $0.00 \%$ & $0.00 \%$ & $0.00 \%$ & $0.01 \%$ \\
\hline & Mallomonas caudata & Iwanoff [Ivanov], 1899 & 2 & 4308 & $0.19 \%$ & $0.05 \%$ & $0.97 \%$ & $0.58 \%$ & $1.18 \%$ \\
\hline & $\begin{array}{l}\text { Mallomonas } \\
\text { duerrschmidtiae }\end{array}$ & $\begin{array}{l}\text { P.A. Siver, J.S. Hamer, \& H.J. } \\
\text { Kling, } 1990\end{array}$ & 2 & 1322 & $0.06 \%$ & $0.01 \%$ & $0.08 \%$ & $0.04 \%$ & $0.29 \%$ \\
\hline & Mallomonas favosa & K.H. Nicholls, 1984 & 2 & 208 & $0.15 \%$ & $0.06 \%$ & $0.02 \%$ & $0.03 \%$ & $0.24 \%$ \\
\hline & Mallomonas & I S Ṕterfi \& Momeu 1976 & 2 & 1026 & $023 \%$ & $138 \%$ & $025 \%$ & $304 \%$ & $240 \%$ \\
\hline & $\begin{array}{l}\text { Transsylvanica } \\
\text { Stipitococcus lauterbornei }\end{array}$ & $\begin{array}{l}\text { L.S. Pmidle, } 1902 \\
\text { Sche }\end{array}$ & $\begin{array}{l}2 \\
1\end{array}$ & $\begin{array}{c}1020 \\
42\end{array}$ & $\begin{array}{l}0.25 \% \\
0.00 \%\end{array}$ & $\begin{array}{l}1.38 \% \\
0.00 \%\end{array}$ & $\begin{array}{l}0.25 \% \\
0.00 \%\end{array}$ & $\begin{array}{l}5.04 \% \\
0.00 \%\end{array}$ & $\begin{array}{l}2.49 \% \\
0.00 \%\end{array}$ \\
\hline & Synura petersenii & Korshikov, 1929 & 2 & 161 & $1.96 \%$ & $7.52 \%$ & $0.52 \%$ & $4.89 \%$ & $2.92 \%$ \\
\hline & Urosolenia epiphyte & & 1 & 13 & $0.01 \%$ & $0.00 \%$ & $0.00 \%$ & $0.00 \%$ & $0.00 \%$ \\
\hline \multirow[t]{8}{*}{ Miozoa } & $\begin{array}{l}\text { Apocalathium cf. } \\
\text { aciculiferum } \\
\text { Ceratium carolinianum }\end{array}$ & $\begin{array}{l}\text { (Lemmermann) Craverio, } \\
\text { Daugbjerg, Moestrup, \& Calado, } \\
2016 \\
\text { (Bailey) Jörgensen, } 1911\end{array}$ & $\begin{array}{l}5 \\
5\end{array}$ & $\begin{array}{c}6329 \\
29316\end{array}$ & $\begin{array}{l}0.02 \% \\
0.01 \%\end{array}$ & $\begin{array}{l}0.02 \% \\
0.04 \%\end{array}$ & $\begin{array}{l}0.03 \% \\
0.21 \%\end{array}$ & $\begin{array}{l}0.22 \% \\
3.48 \%\end{array}$ & $\begin{array}{l}0.32 \% \\
1.92 \%\end{array}$ \\
\hline & & (Eddy) F.M.G. McCarthy, H.F. & & & & & & & \\
\hline & $\begin{array}{l}\text { Fusiperidinium } \\
\text { wisconsinense }\end{array}$ & $\begin{array}{l}\text { Gu, K.N. Mertens, \& Carbonell- } \\
\text { Moore, } 2018\end{array}$ & 5 & 35452 & $0.75 \%$ & $0.17 \%$ & $13.85 \%$ & $14.61 \%$ & $5.43 \%$ \\
\hline & Naiadinium polonicum & (Woloszynska) Carty, 2014 & 5 & 21987 & $0.05 \%$ & $0.00 \%$ & $0.84 \%$ & $0.00 \%$ & $0.73 \%$ \\
\hline & $\begin{array}{l}\text { Parvodinium } \\
\text { inconspicuum }\end{array}$ & (Lemmermann) Carty, 2008 & 5 & 1843 & $0.26 \%$ & $0.38 \%$ & $0.31 \%$ & $1.81 \%$ & $1.72 \%$ \\
\hline & Peridinium cf. bipes & F. Stein, 1883 & 5 & 64730 & $0.38 \%$ & $0.02 \%$ & $13.50 \%$ & $1.50 \%$ & $5.22 \%$ \\
\hline & Peridinium sp. 1 & Ehrenberg, 1830 & 5 & 26234 & $0.12 \%$ & $0.04 \%$ & $1.89 \%$ & $3.29 \%$ & $2.57 \%$ \\
\hline & Peridinium sp. 2 & Ehrenberg, 1830 & 5 & 30708 & $0.02 \%$ & $0.03 \%$ & $0.35 \%$ & $2.45 \%$ & $1.55 \%$ \\
\hline
\end{tabular}




\begin{tabular}{|c|c|c|c|c|c|c|c|c|c|}
\hline Phylum & Genus and species & Authority & MBFG & $\begin{array}{c}\text { Biovolume } \\
\left(\text { um }^{3}\right)\end{array}$ & $\begin{array}{l}\text { Dark Rel. } \\
\text { Mean } \\
\text { Cells }(\%)\end{array}$ & $\begin{array}{c}\text { Clear } \\
\text { Rel. } \\
\text { Mean } \\
\text { Cells }(\%)\end{array}$ & $\begin{array}{c}\text { Dark Rel. } \\
\text { Mean } \\
\text { Biovolume } \\
(\%)\end{array}$ & $\begin{array}{c}\text { Clear Rel. } \\
\text { Mean } \\
\text { Biovolume } \\
(\%)\end{array}$ & $\begin{array}{c}\text { Biovolume } \\
\% \\
\text { Contribution } \\
\text { to } \\
\text { Dissimilarity }\end{array}$ \\
\hline Miozoa & $\begin{array}{l}\text { Naked dinoflagellate } \\
\text { Unknown dinoflagellate }\end{array}$ & & $\begin{array}{l}5 \\
5\end{array}$ & $\begin{array}{c}5236 \\
688\end{array}$ & $\begin{array}{l}0.00 \% \\
0.03 \%\end{array}$ & $\begin{array}{l}0.00 \% \\
0.01 \%\end{array}$ & $\begin{array}{l}0.00 \% \\
0.01 \%\end{array}$ & $\begin{array}{l}0.00 \% \\
0.01 \%\end{array}$ & $\begin{array}{l}0.01 \% \\
0.05 \%\end{array}$ \\
\hline \multirow[t]{23}{*}{ Cyanobacteria } & Aphanocapsa sp. MD & C. Nägeli, 1849 & 7 & 8 & $0.23 \%$ & $0.00 \%$ & $0.00 \%$ & $0.00 \%$ & $0.01 \%$ \\
\hline & Aphanothece sp. SM & C. Nägeli, 1849 & 7 & 4 & $0.04 \%$ & $0.00 \%$ & $0.00 \%$ & $0.00 \%$ & $0.00 \%$ \\
\hline & Aphanothece sp. MD & C. Nägeli, 1849 & 7 & 15 & $0.64 \%$ & $0.04 \%$ & $0.01 \%$ & $0.00 \%$ & $0.04 \%$ \\
\hline & Aphanothece sp. $L G$ & $\begin{array}{l}\text { C. Nägeli, } 1849 \\
\text { (N.L. Gardner) Komárek \& }\end{array}$ & 7 & 32 & $0.00 \%$ & $0.07 \%$ & $0.00 \%$ & $0.00 \%$ & $0.02 \%$ \\
\hline & Asterocapsa cf. nidulans & Komárková-Legnerová, 2006 & 7 & 9 & $0.08 \%$ & $0.00 \%$ & $0.00 \%$ & $0.00 \%$ & $0.01 \%$ \\
\hline & Chroococcus sp. & Nägeli, 1849 & 7 & 69 & $0.33 \%$ & $0.00 \%$ & $0.02 \%$ & $0.00 \%$ & $0.11 \%$ \\
\hline & Chroococcus sp. $L G$ & Nägeli, 1849 & 7 & 1186 & $0.00 \%$ & $0.00 \%$ & $0.00 \%$ & $0.00 \%$ & $0.01 \%$ \\
\hline & Cyanosarcina sp. $c f$. & L. Kovácik, 1988 & 7 & 160 & $0.00 \%$ & $0.00 \%$ & $0.00 \%$ & $0.00 \%$ & $0.00 \%$ \\
\hline & Dolichospermum sp. 1 & $\begin{array}{l}\text { (Ralfs ex Bornet \& Flahault) P. } \\
\text { Wacklin, L. Hoffmann \& J. } \\
\text { Komárek, } 2009\end{array}$ & 3 & 1453 & $0.13 \%$ & $0.00 \%$ & $0.02 \%$ & $0.00 \%$ & $0.04 \%$ \\
\hline & & $\begin{array}{l}\text { (Ralfs ex Bornet \& Flahault) P. } \\
\text { Wacklin, L. Hoffmann \& J. }\end{array}$ & & & & & & & \\
\hline & Dolichospermum sp. 2 cf. & Komárek, 2009 & 3 & 180 & $0.19 \%$ & $0.56 \%$ & $0.00 \%$ & $0.00 \%$ & $0.02 \%$ \\
\hline & & $\begin{array}{l}\text { (Ralfs ex Bornet \& Flahault) P. } \\
\text { Wacklin, L. Hoffmann \& J. }\end{array}$ & & & & & & & \\
\hline & Dolichospermum sp. 3 & Komárek, 2009 & 3 & 1307 & $0.13 \%$ & $0.09 \%$ & $0.01 \%$ & $0.01 \%$ & $0.07 \%$ \\
\hline & Eucapsis sp. SM & $\begin{array}{l}\text { F.E. Clements \& H.L. Shantz, } \\
1909\end{array}$ & 7 & 1 & $2.77 \%$ & $0.36 \%$ & $0.00 \%$ & $0.00 \%$ & $0.05 \%$ \\
\hline & Eucapsis sp. $M D$ & $\begin{array}{l}\text { F.E. Clements \& H.L. Shantz, } \\
1909\end{array}$ & 7 & 14 & $0.00 \%$ & $0.04 \%$ & $0.00 \%$ & $0.00 \%$ & $0.01 \%$ \\
\hline & Geitlerinema $c f$. & (Greville ex Gomont) & & & & & & & \\
\hline & splendidum & Anagnostidis, 1989 & 3 & 437 & $0.06 \%$ & $0.00 \%$ & $0.00 \%$ & $0.00 \%$ & $0.01 \%$ \\
\hline & Gloeocapsa sp. 1 cf. & Kützing, 1843 & 7 & 82 & $0.53 \%$ & $0.02 \%$ & $0.05 \%$ & $0.00 \%$ & $0.21 \%$ \\
\hline & Gloeocapsa sp. 2 cf. & Kützing, 1843 & 7 & 140 & $0.06 \%$ & $0.04 \%$ & $0.01 \%$ & $0.01 \%$ & $0.05 \%$ \\
\hline & Gloeocapsa cf. novacekii & Komárek \& Anagnotidis, 1995 & 7 & 17 & $0.57 \%$ & $0.73 \%$ & $0.01 \%$ & $0.06 \%$ & $0.16 \%$ \\
\hline & $\begin{array}{l}\text { Gloeocapsopsis cf. } \\
\text { dvorakii }\end{array}$ & $\begin{array}{l}\text { (Novácek) Komárek \& } \\
\text { Anagnostidis ex Komárek, } 1993\end{array}$ & 7 & 22 & $0.03 \%$ & $0.00 \%$ & $0.00 \%$ & $0.00 \%$ & $0.01 \%$ \\
\hline & Gomphosphaeria spp. & Kützing, 1836 & 7 & 44785 & $0.01 \%$ & $0.00 \%$ & $0.23 \%$ & $0.00 \%$ & $0.12 \%$ \\
\hline & $\begin{array}{l}\text { Limnococcus } c f \text {. } \\
\text { limneticus }\end{array}$ & $\begin{array}{l}\text { (Lemmermann) Komárková, } \\
\text { Jezberová, O. Komárek, \& } \\
\text { Zapomelová, } 2010\end{array}$ & 7 & 17 & $12.07 \%$ & $9.01 \%$ & $0.18 \%$ & $0.36 \%$ & $1.04 \%$ \\
\hline
\end{tabular}




\begin{tabular}{|c|c|c|c|c|c|c|c|c|c|}
\hline Phylum & Genus and species & Authority & MBFG & $\begin{array}{c}\text { Biovolume } \\
\left(\mathbf{u m}^{3}\right)\end{array}$ & $\begin{array}{l}\text { Dark Rel. } \\
\text { Mean } \\
\text { Cells }(\%) \\
\end{array}$ & $\begin{array}{c}\text { Clear } \\
\text { Rel. } \\
\text { Mean } \\
\text { Cells }(\%)\end{array}$ & $\begin{array}{c}\text { Dark Rel. } \\
\text { Mean } \\
\text { Biovolume } \\
(\%)\end{array}$ & $\begin{array}{c}\text { Clear Rel. } \\
\text { Mean } \\
\text { Biovolume } \\
(\%)\end{array}$ & $\begin{array}{c}\text { Biovolume } \\
\% \\
\text { Contribution } \\
\text { to } \\
\text { Dissimilarity }\end{array}$ \\
\hline \multirow{19}{*}{ Cyanobacteria } & & $\begin{array}{l}\text { (Komárek \& Anagnostidis) } \\
\text { Komárková, Jezberová, O. }\end{array}$ & & & & & & & \\
\hline & Limnococcus sp. 1 & Komárek, \& Zapomelová, 2010 & 1 & 2 & $3.60 \%$ & $3.16 \%$ & $0.02 \%$ & $0.01 \%$ & $0.15 \%$ \\
\hline & Limnothrix sp. 1 & M.-E. Meffert, 1988 & 3 & 254 & $1.13 \%$ & $0.13 \%$ & $0.02 \%$ & $0.00 \%$ & $0.09 \%$ \\
\hline & Limnothrix sp. 2 & M.-E. Meffert, 1988 & 3 & 189 & $0.24 \%$ & $0.17 \%$ & $0.01 \%$ & $0.01 \%$ & $0.06 \%$ \\
\hline & Merismopedia sp. SM & Meyen, 1839 & 7 & 0 & $4.57 \%$ & $43.41 \%$ & $0.00 \%$ & $0.05 \%$ & $0.29 \%$ \\
\hline & Merismopedia sp. MD & Meyen, 1839 & 7 & 12 & $0.03 \%$ & $0.07 \%$ & $0.00 \%$ & $0.00 \%$ & $0.04 \%$ \\
\hline & Merismopedia sp. $L G$ & Meyen, 1839 & 7 & 56 & $0.13 \%$ & $0.00 \%$ & $0.01 \%$ & $0.00 \%$ & $0.03 \%$ \\
\hline & Microcystis sp.cf. & Lemmermann, 1907 & 7 & 1 & $0.00 \%$ & $0.02 \%$ & $0.00 \%$ & $0.00 \%$ & $0.00 \%$ \\
\hline & Oscillatoria sp. & Vaucher ex Gomont, 1892 & 3 & 1597 & $0.36 \%$ & $0.01 \%$ & $0.02 \%$ & $0.01 \%$ & $0.07 \%$ \\
\hline & Planktolyngbya sp. & Anagnostidis \& Komárek, 1988 & 3 & 259 & $0.46 \%$ & $0.31 \%$ & $0.00 \%$ & $0.00 \%$ & $0.03 \%$ \\
\hline & Planktothrix sp. & $\begin{array}{l}\text { K. Anagnostidis \& J. Komárek, } \\
1988\end{array}$ & 3 & 92 & $0.25 \%$ & $1.04 \%$ & $0.00 \%$ & $0.00 \%$ & $0.03 \%$ \\
\hline & Pseudanabaena sp. 1 cf. & Lauterborn, 1915 & 3 & 1535 & $0.40 \%$ & $0.30 \%$ & $0.11 \%$ & $0.08 \%$ & $0.28 \%$ \\
\hline & Pseudanabaena sp. 2 cf. & Lauterborn, 1915 & 3 & 216 & $0.38 \%$ & $0.14 \%$ & $0.00 \%$ & $0.00 \%$ & $0.02 \%$ \\
\hline & $\begin{array}{l}\text { Pseudophormidium sp. } \\
\text { Rhabdoderma sp. } 1\end{array}$ & $\begin{array}{l}\text { (Forti) Anagnostidis \& Komárek, } \\
1988 \\
\text { Schmidle \& Lauterborn, } 1900\end{array}$ & $\begin{array}{l}3 \\
7\end{array}$ & $\begin{array}{c}560 \\
0\end{array}$ & $\begin{array}{l}0.36 \% \\
0.62 \%\end{array}$ & $\begin{array}{l}0.00 \% \\
4.41 \%\end{array}$ & $\begin{array}{l}0.00 \% \\
0.00 \%\end{array}$ & $\begin{array}{l}0.00 \% \\
0.00 \%\end{array}$ & $\begin{array}{l}0.01 \% \\
0.05 \%\end{array}$ \\
\hline & Rhabdoderma sp. 2 & Schmidle \& Lauterborn, 1900 & 7 & 1 & $0.41 \%$ & $1.25 \%$ & $0.00 \%$ & $0.00 \%$ & $0.03 \%$ \\
\hline & Scytonema sp. & $\begin{array}{l}\text { C. Agardh ex É. Bornet, \& C. } \\
\text { Flahault, } 1886\end{array}$ & 3 & 855 & $0.08 \%$ & $0.00 \%$ & $0.00 \%$ & $0.00 \%$ & $0.02 \%$ \\
\hline & Scytonema sp. 2 cf. & $\begin{array}{l}\text { C. Agardh ex É. Bornet, \& C. } \\
\text { Flahault, } 1886\end{array}$ & 3 & 5407 & $0.21 \%$ & $0.06 \%$ & $0.09 \%$ & $0.05 \%$ & $0.15 \%$ \\
\hline & $\begin{array}{l}\text { Synechococcus cf. } \\
\text { elongatus } \\
\text { Unknown cyanobacteria }\end{array}$ & (Nägeli) Nägeli, 1849 & 7 & 8 & $0.03 \%$ & $0.72 \%$ & $0.00 \%$ & $0.01 \%$ & $0.05 \%$ \\
\hline & filament & & 3 & 260 & $0.01 \%$ & $0.00 \%$ & $0.00 \%$ & $0.00 \%$ & $0.00 \%$ \\
\hline
\end{tabular}


Table 4: Correlation coefficients for physicochemical vectors with axis 1 and 2 of the clear and dark phase NMDS based on taxon relative biovolumes (Fig. 7). Vectors include Pacific Decadal Oscillation Index (PDO), Southern Oscillation Index (SOI),

precipitation as an end of the month total (PPT), monthly mean ground water stage (GWS), monthly mean lake water stage (LWS), Secchi disk depth (SECCHI), Photosynthetically active radiation extinction rate (KD), surface water total organic carbon (TOC), surface water color (PCU), monthly mean $\mathrm{pH}(\mathrm{PH})$, surface water total phosphorus (TP), surface water total nitrogen (TN), and surface water chlorophyll-a (CHLA).

\begin{tabular}{c|ccccccccccccc} 
Phase & PDO & SOI & PPT & GWS & LWS & SECCHI & KD & TOC & PCU & PH & TP & TN & CHLA \\
\hline Dark Axis 1 & 0.35 & -0.20 & -0.06 & 0.32 & 0.24 & -0.32 & 0.24 & 0.12 & 0.18 & -0.25 & 0.18 & 0.03 & 0.15 \\
Dark Axis 2 & 0.07 & -0.05 & -0.08 & 0.49 & 0.26 & -0.57 & 0.57 & 0.59 & 0.59 & 0.39 & 0.18 & 0.34 & 0.50 \\
\hline Clear Axis 1 & -0.01 & 0.47 & -0.38 & 0.07 & -0.33 & 0.22 & -0.37 & -0.35 & -0.34 & 0.30 & -0.63 & -0.27 & -0.26 \\
Clear Axis 2 & 0.16 & -0.13 & -0.14 & -0.14 & -0.34 & 0.22 & -0.33 & -0.38 & -0.43 & 0.36 & -0.03 & -0.09 & -0.14
\end{tabular}


Figure 1: Conceptual diagram of anticipated drivers of phytoplankton succession in dark-water (left) and clear-water (right) conditions. GWS = ground water stage, LWS = lake water stage, $c D O C=$ colored dissolved organic carbon.

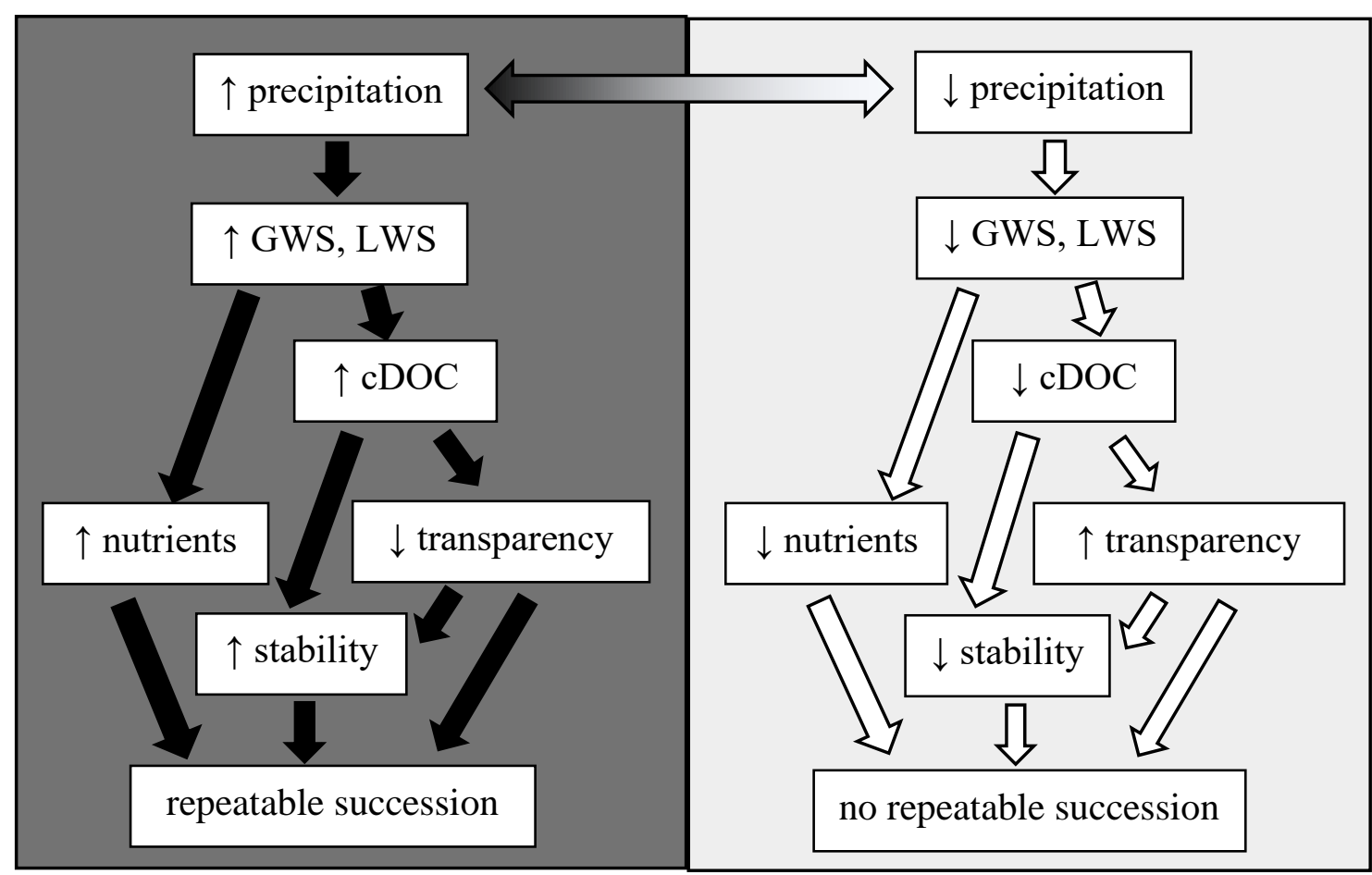


Figure 2: Monthly mean ground water stage (solid line), quarterly surface water color (dashed line), and monthly mean Pacific Decadal Oscillation index (PDO) values (bars). The first vertical dashed line indicates a shift in surface water color $<30$ PCU (dark 1 to clear) and the second vertical dashed line indicates a shift surface water color $>30 \mathrm{PCU}$ (clear to dark 2). Water color and ground water stage were strongly correlated, $R^{2}=$ 0.79 .

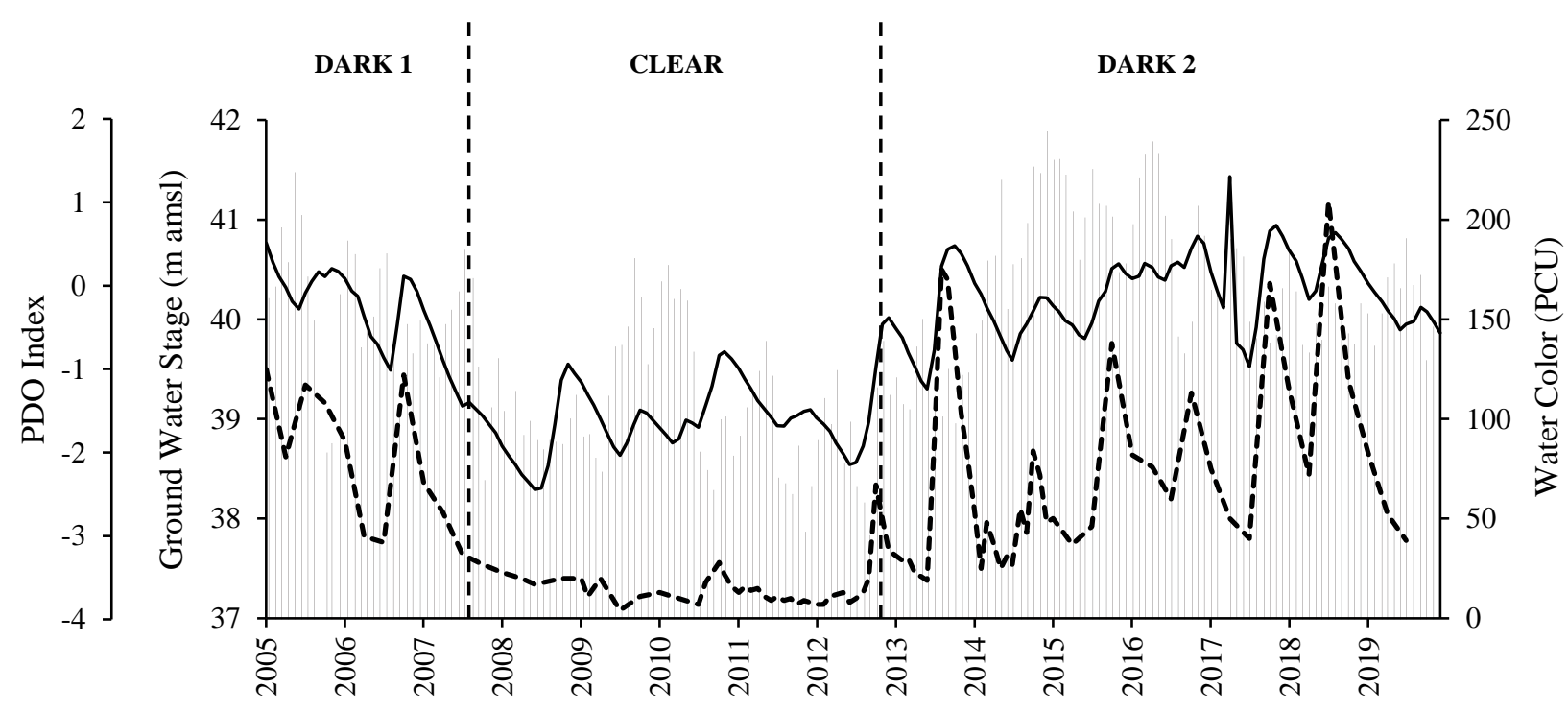


Figure 3: Mean monthly photosynthetically active radiation (PAR) extinction rate ( $K_{d} \mathrm{~m}^{-}$ $\left.{ }^{1}\right) \pm$ standard error (SE) for the time period January 2005-December 2019. Filled circles represent dark 1 and 2 phases while open circles represent clear phase.

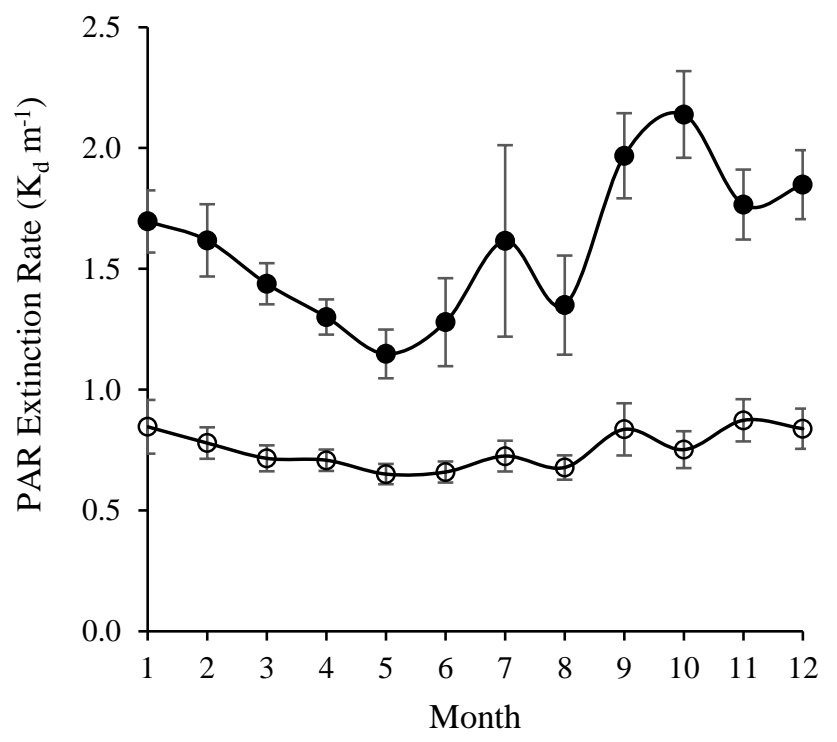


Figure 4: Time series of phytoplankton relative cell density (left) and relative biovolume (right) of Bacillariophyta, Charophyta, Chlorophyta, Ochrophyta (Crysophytes and Synurophytes), Dinoflagellata (Miozoa), and Cyanophyta. Phyla Euglenophya and Cryptophyta were excluded from this figure due to the low abundance and biomass of these taxa throughout the timeseries. Vertical dashed lines represent the clear-dark phase shift in water color (see Fig. 2). The first vertical solid line indicates where phytoplankton began responding to the shift from dark 1 to clear phase, as determined by cluster analysis at a level of $22 \%$ similarity. The second vertical dashed line indicates where phytoplankton began responding to the transition back to dark phase (dark 2).
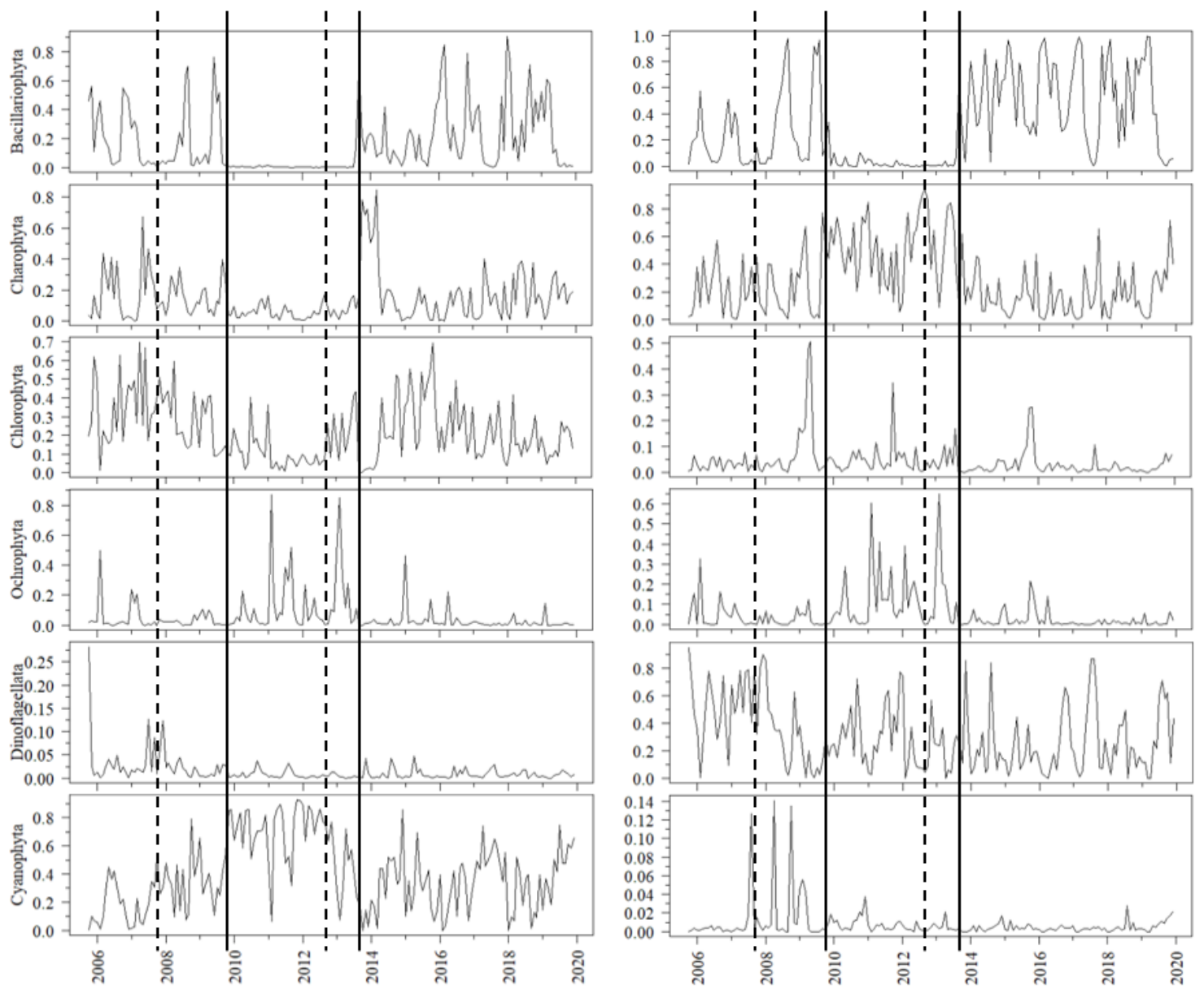
Figure 5: Two-dimensional NMDS ordination biplot of monthly phytoplankton taxon relative biovolume. Open circles represent the clear phase, while dark symbols represent dark phases 1 and 2. Vectors are provided for physicochemical variables with $R^{2}>0.3$ including precipitation (PPT), monthly mean ground water stage (GWS), monthly mean lake water stage (LWS), Secchi disk depth (SECCHI), photosynthetically active radiation extinction rate (KD), surface water total organic carbon (TOC), surface water color (PCU), surface water total nitrogen (TN), and surface water chlorophyll-a (CHLA). Dashed circles contain samples with $>25 \%$ similarity.

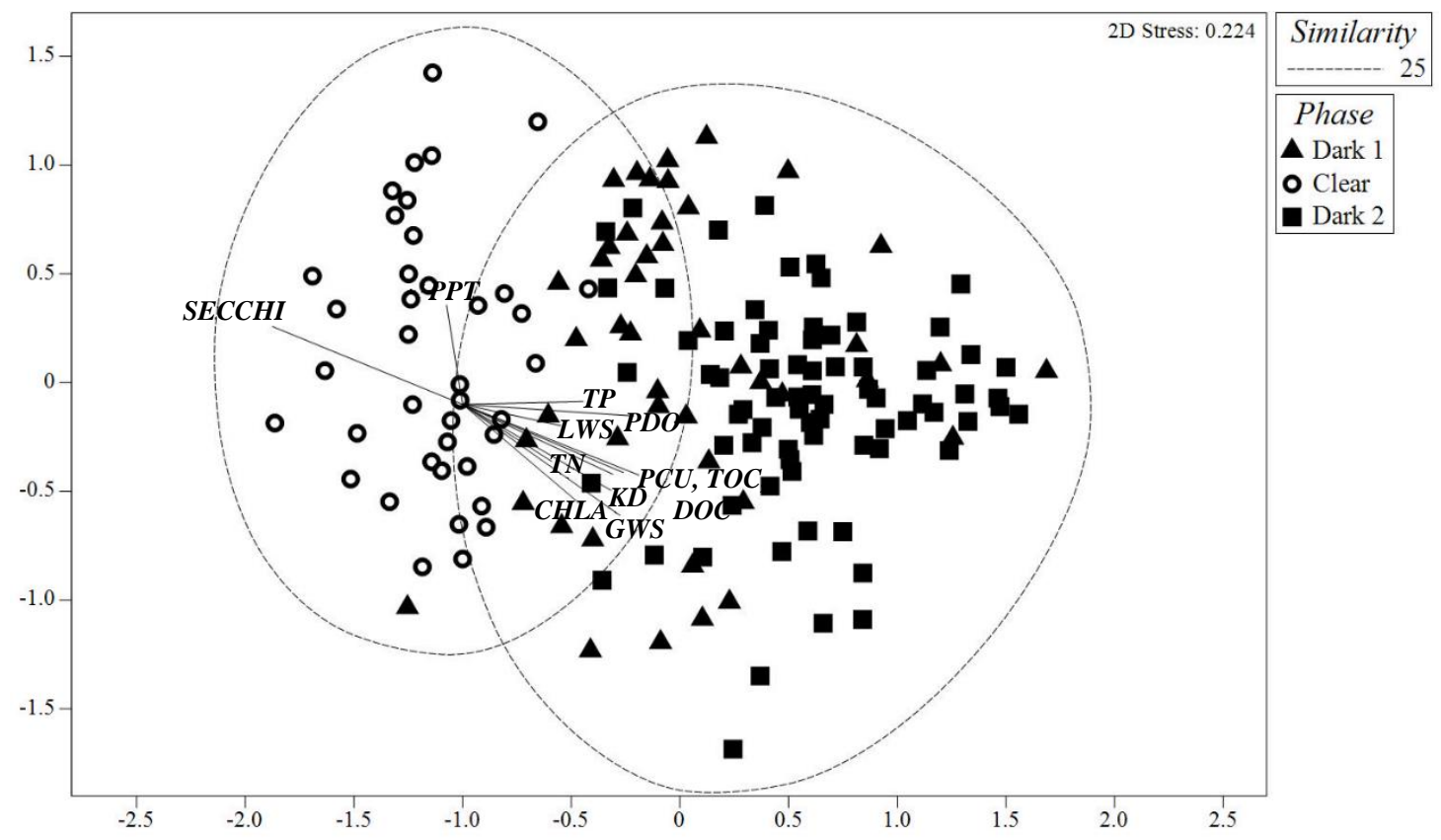


Figure 6: Change in Bray-Curtis similarity across sample pairs collected 1 to 170 months apart (October 2005-December 2019). The first datapoint indicates the average similarity of samples collected 1 month apart (162 comparisons), while the last datapoint indicates the average similarity of samples collected 170 months apart (just one comparison). Error bars indicate $95 \%$ confidence intervals of similarity.

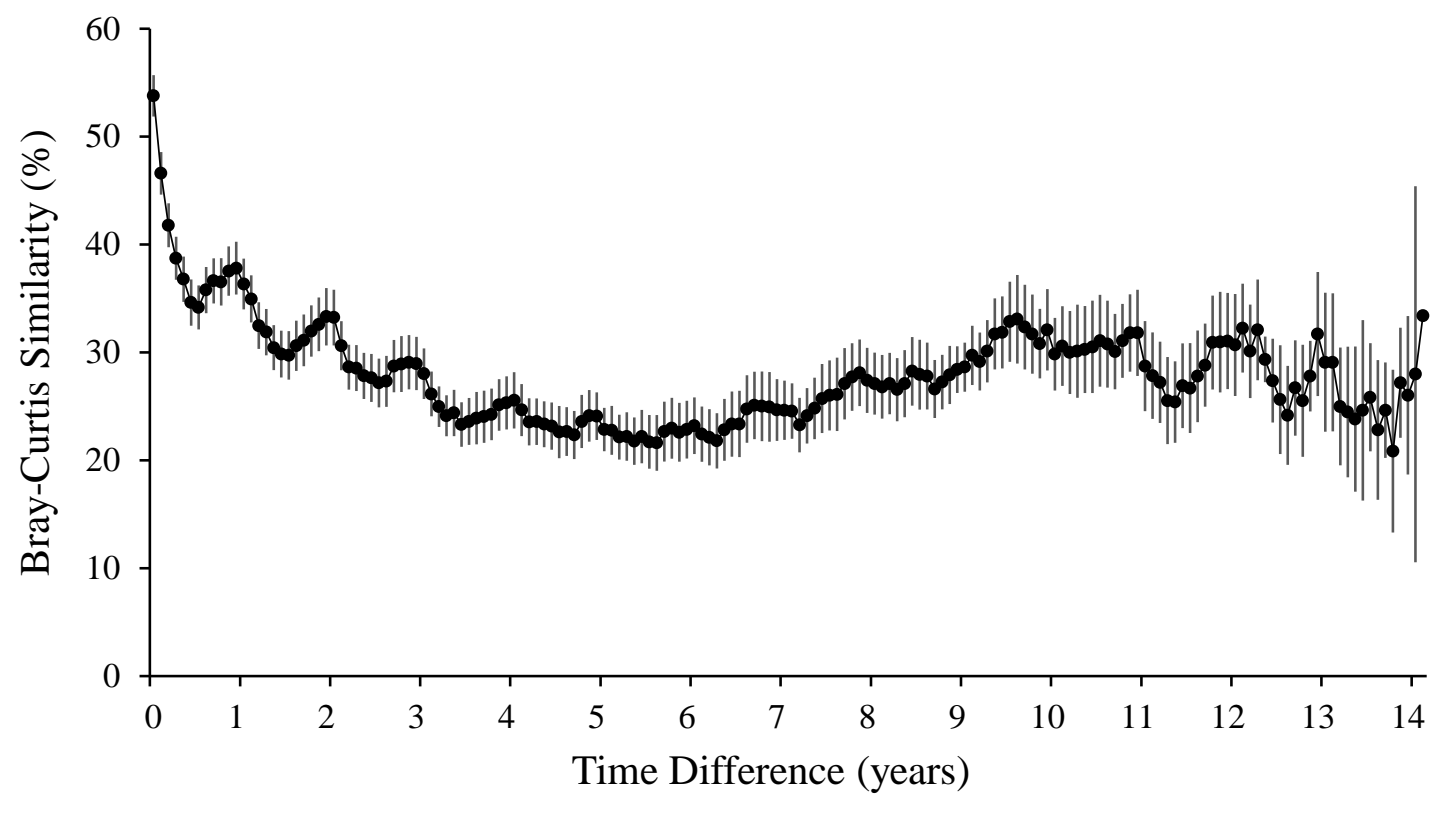


Figure 7: Decomposed time series showing the trend of water color (solid line) and phytoplankton relative biovolume NMDS axis 1 score (dashed line) from January 2005December 2019.

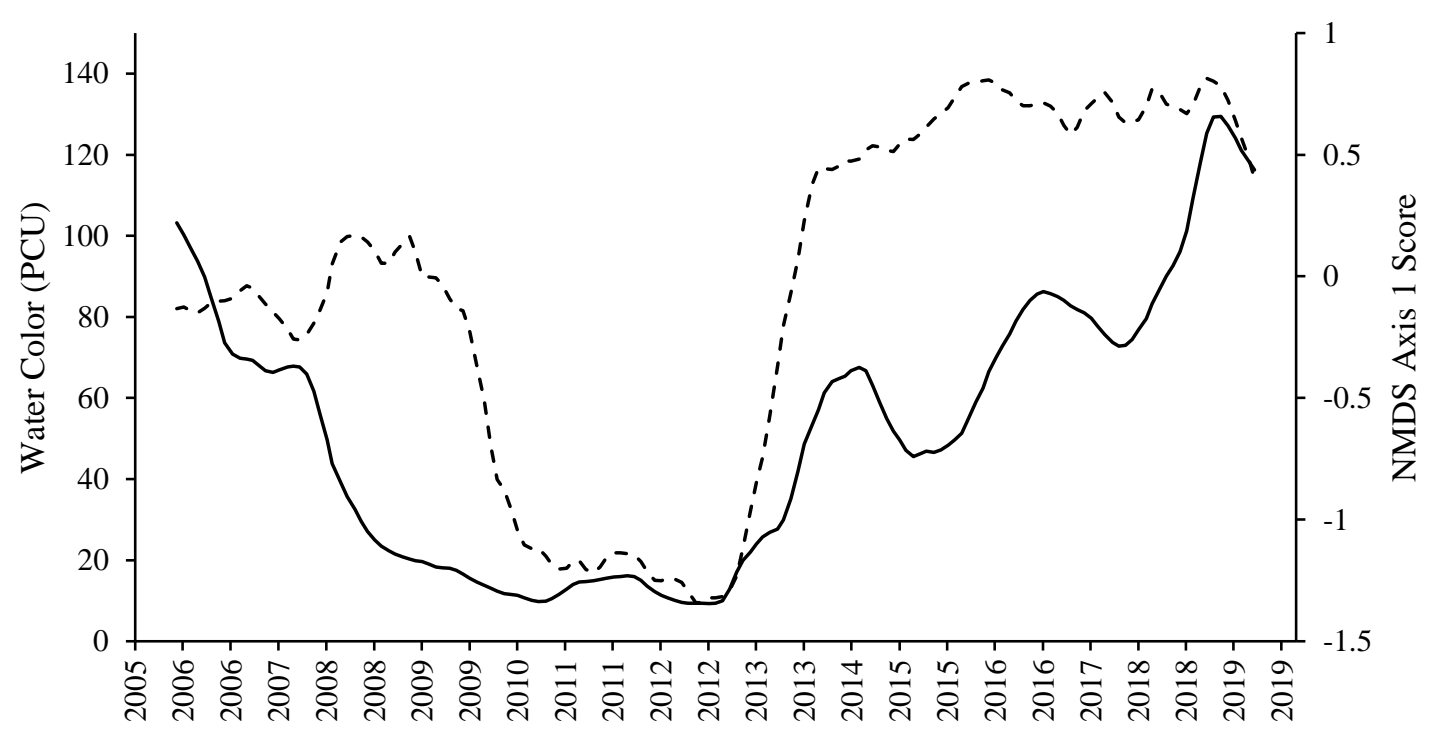


Figure 8: Two-dimensional NMDS ordination biplot of monthly phytoplankton relative taxon biovolume for dark phases 1 and 2 combined (a) and clear phase (b) coded by season. Diamond $=$ spring, circle $=$ summer, triangle $=$ fall, and square $=$ winter . Vectors are provided for physicochemical variables with $R^{2}>0.3$ for one or both phases. Vectors include Pacific Decadal Oscillation index (PDO), Southern Oscillation Index (SOI), monthly mean ground water stage (GWS), monthly mean lake water stage (LWS), Secchi disk depth (SECCHI), monthly surface water pH (PH), surface water total nitrogen (TN), surface water total phosphorus (TP), surface water color (PCU), surface water total organic carbon (TOC), surface water dissolved organic carbon (DOC), photosynthetically active radiation extinction rate $(K D)$, and surface water chlorophyll-a (CHLA). Dashed circles contain samples with >25\% similarity.
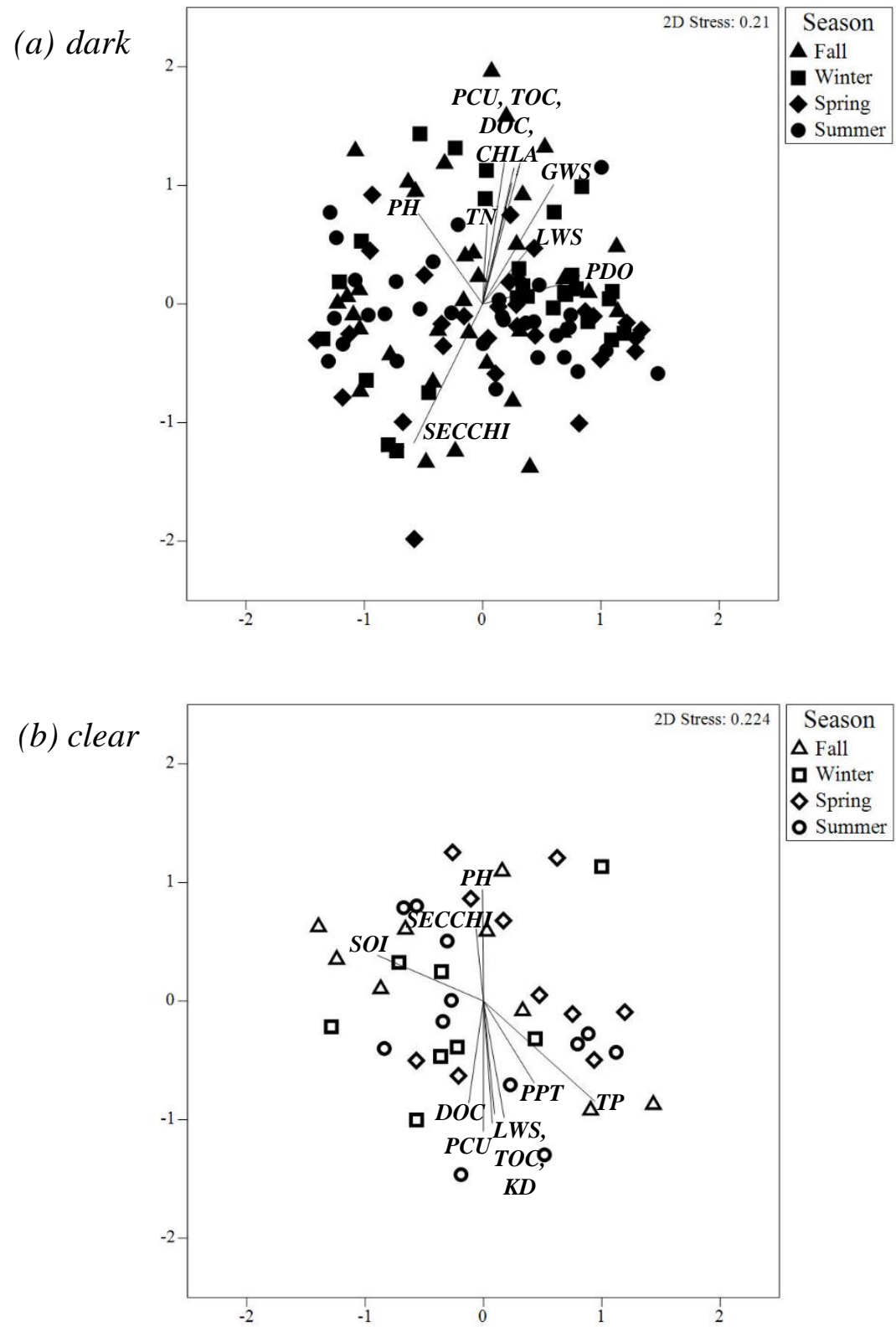
Figure 9: Example two-dimensional NMDS ordination biplots of phytoplankton relative taxon biovolume with monthly trajectories during a dark year $(a, 2017)$ and a clear year $(b, 2011)$.
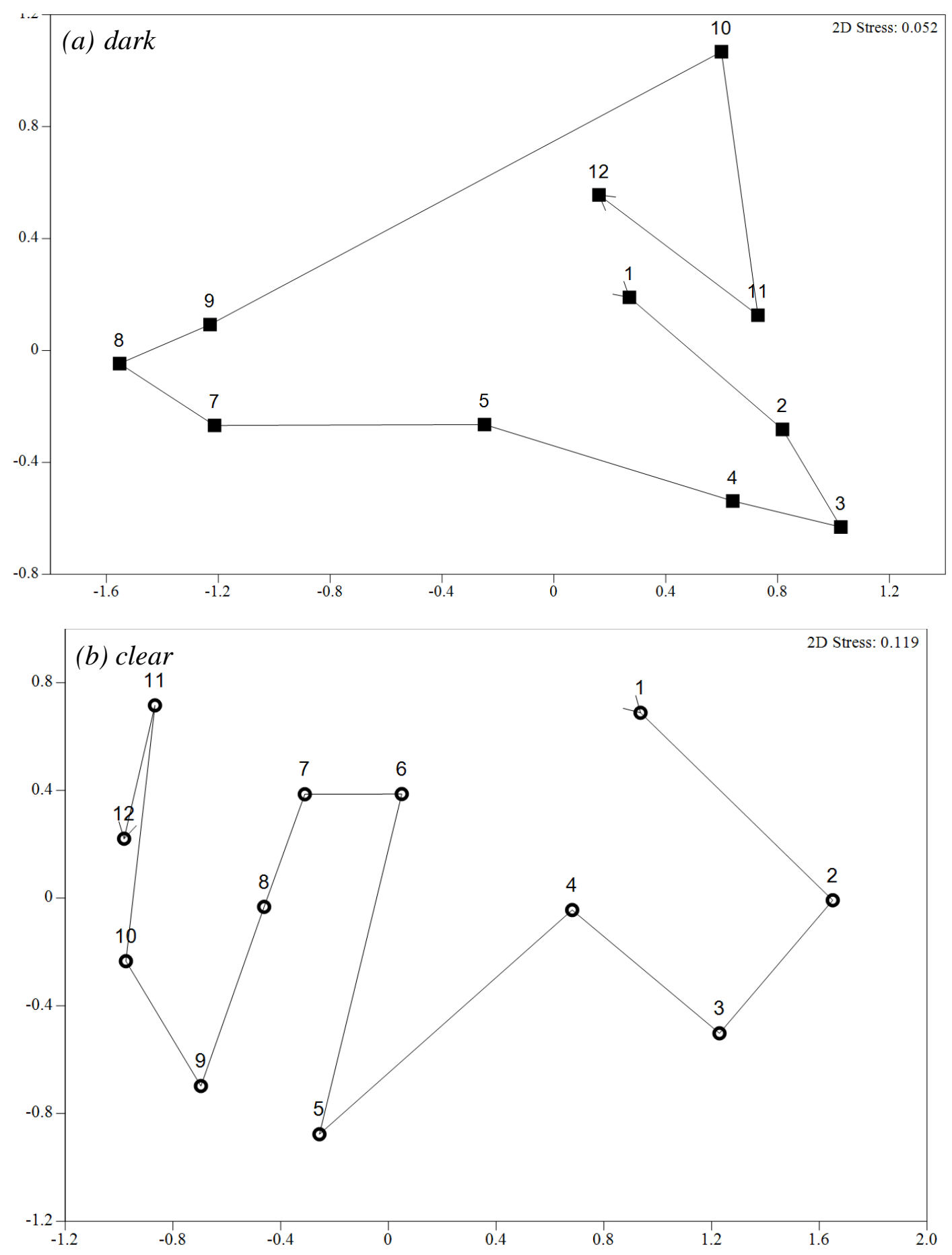
Figure 10: Mean percent contribution to relative biovolume of each morphology-based functional group $(M B F G)$ in dark (a) and clear $(b)$ phase years. Functional groups are: 1) small organisms with high surface area to volume ratio, 2) small flagellated organisms with siliceous exoskeletal structures, 3) large filaments with aerotopes, 4) medium size organisms lacking specialized traits, 5) medium to large size unicellular flagellates, 6) non-flagellated organisms with siliceous exoskeletons, 7) large mucilaginous colonies, and 8) large filaments lacking aerotopes. X-axis represents months of the year JanuaryDecember.

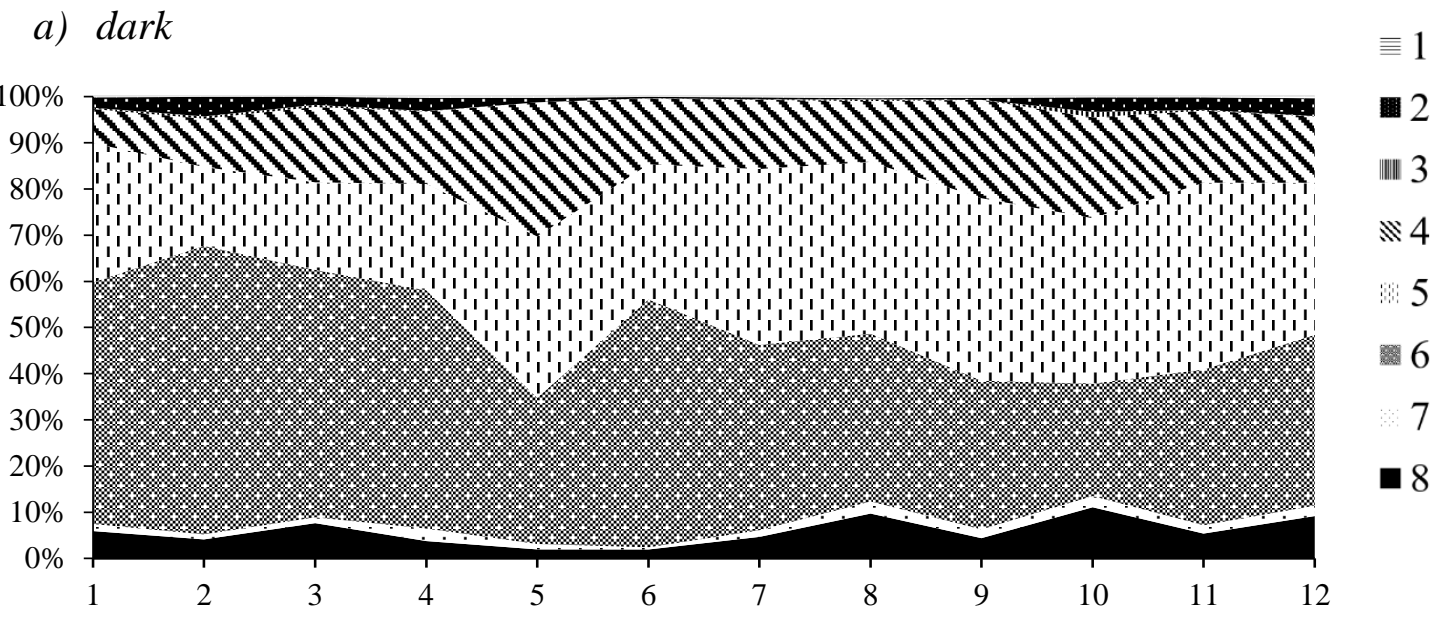

b) clear

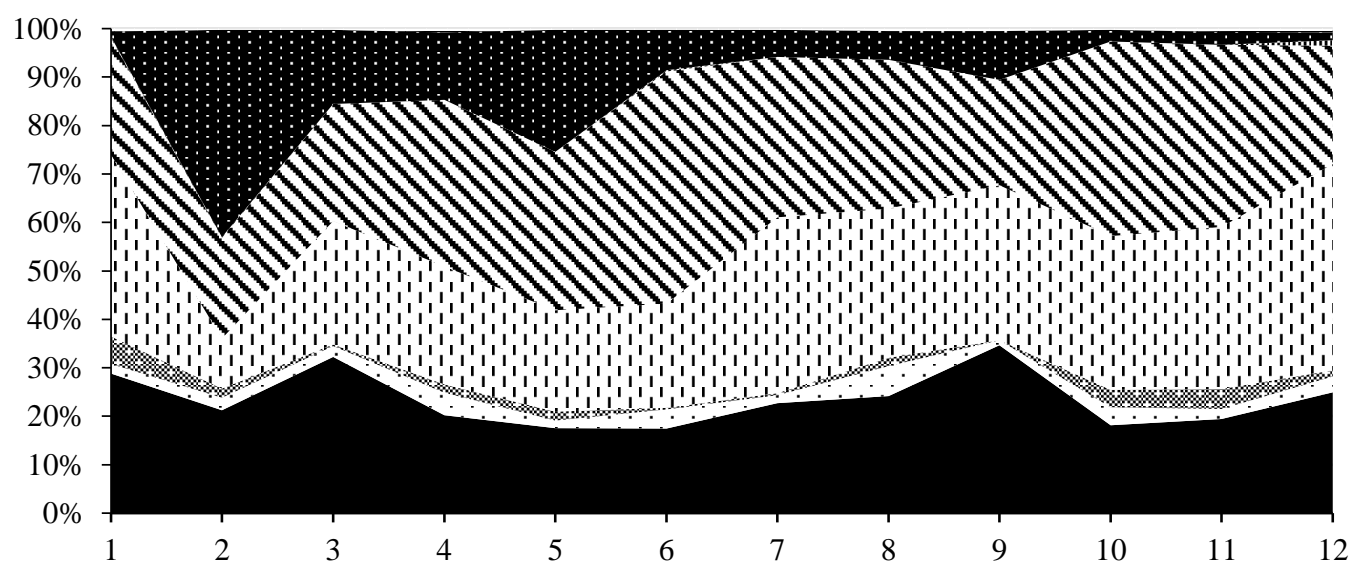


Figure 11: Two-dimensional NMDS ordination biplot of taxon relative biovolumes with bubbles scaled to the percent contribution of each functional group to total sample biovolume in dark (black bubbles) and clear (light grey bubbles) phases. Dotted lines contain samples with $25 \%$ compositional similarity. Morphology-based functional groups (MBFGs) include: 1) small organisms with high surface area to volume ratio, 2) small flagellated organisms with siliceous exoskeletal structures, 3) large filaments with aerotopes, 4) medium size organisms lacking specialized traits, 5) medium to large size unicellular flagellates, 6) non-flagellated organisms with siliceous exoskeletons, 7) large mucilaginous colonies, and 8) large filaments lacking aerotopes.

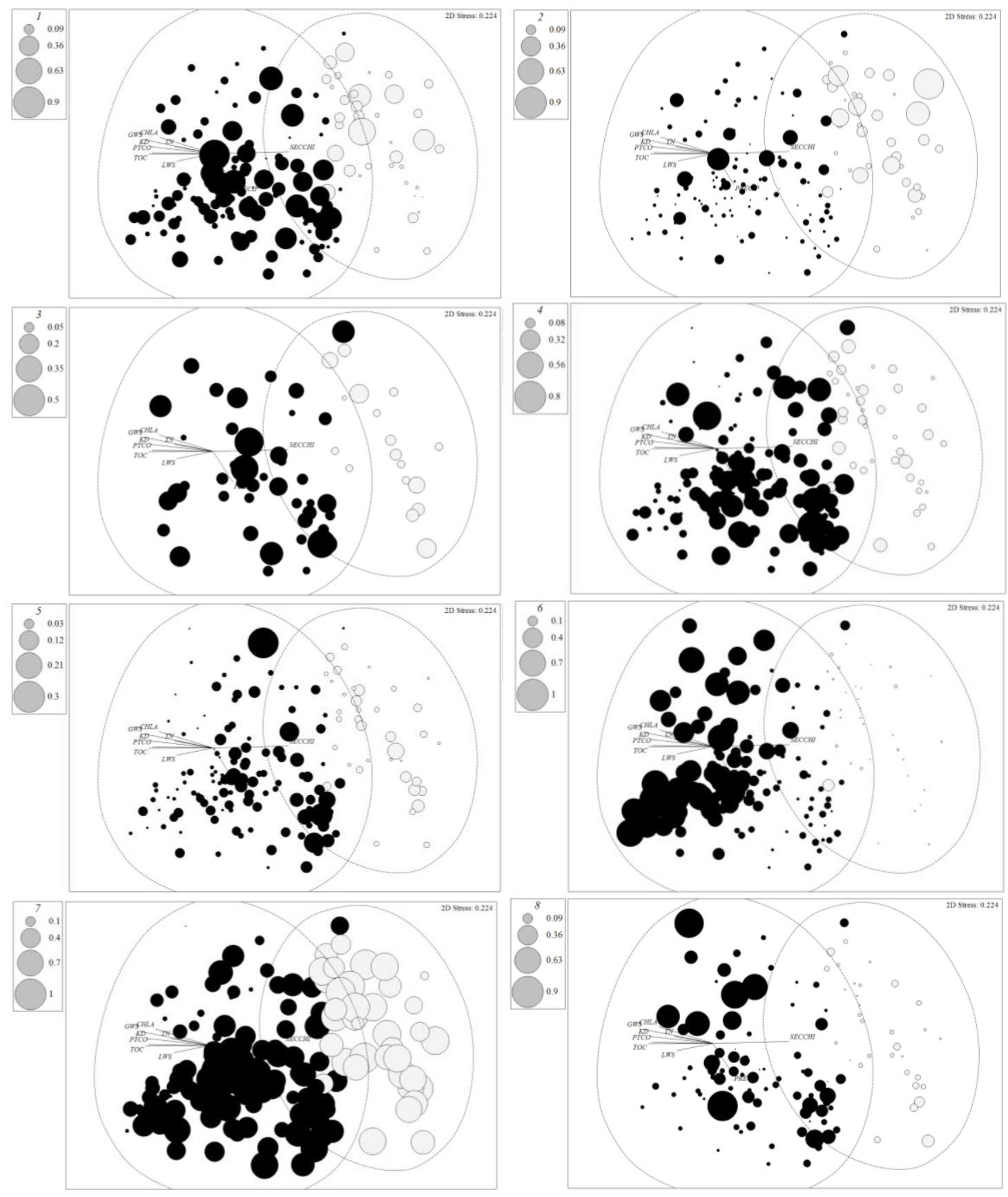




\section{APPENDIX:}

Images of select species.

1. Bacillariophyta

Achanthes chsp01 Bory, 1822

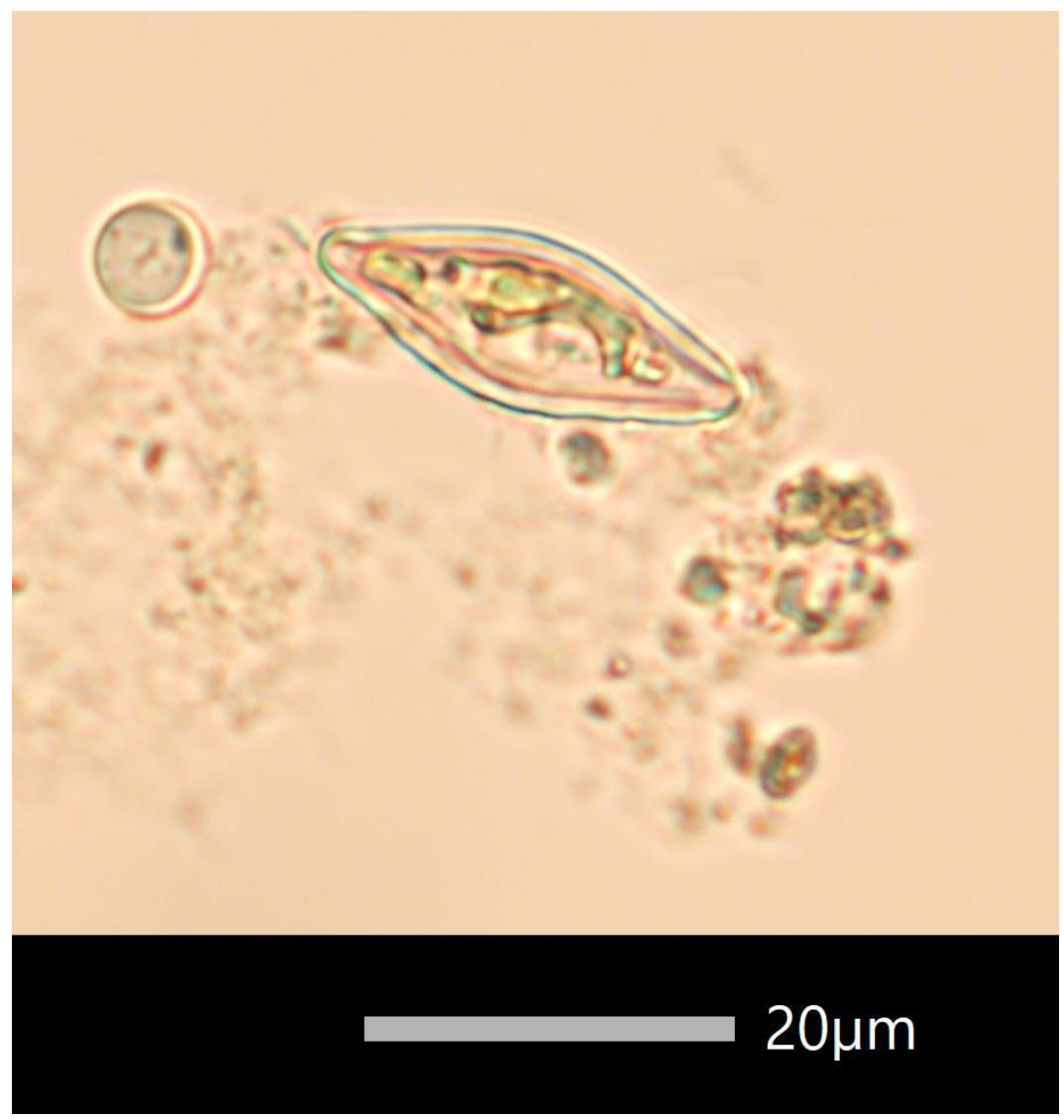


Asterionella formosa Hassall, 1850
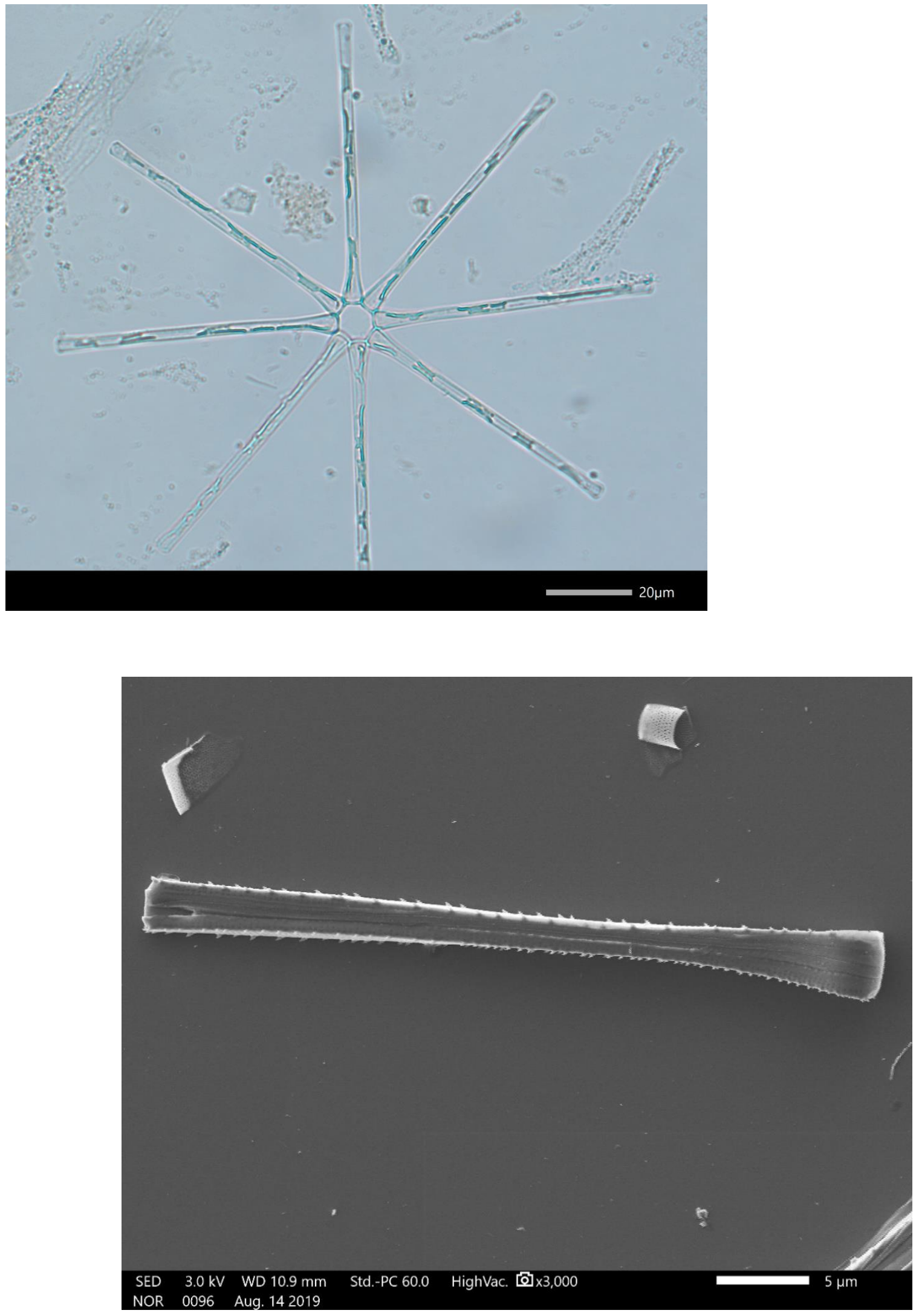
Aulacoseira herzogii (Lemermann) Simonsen, 1979
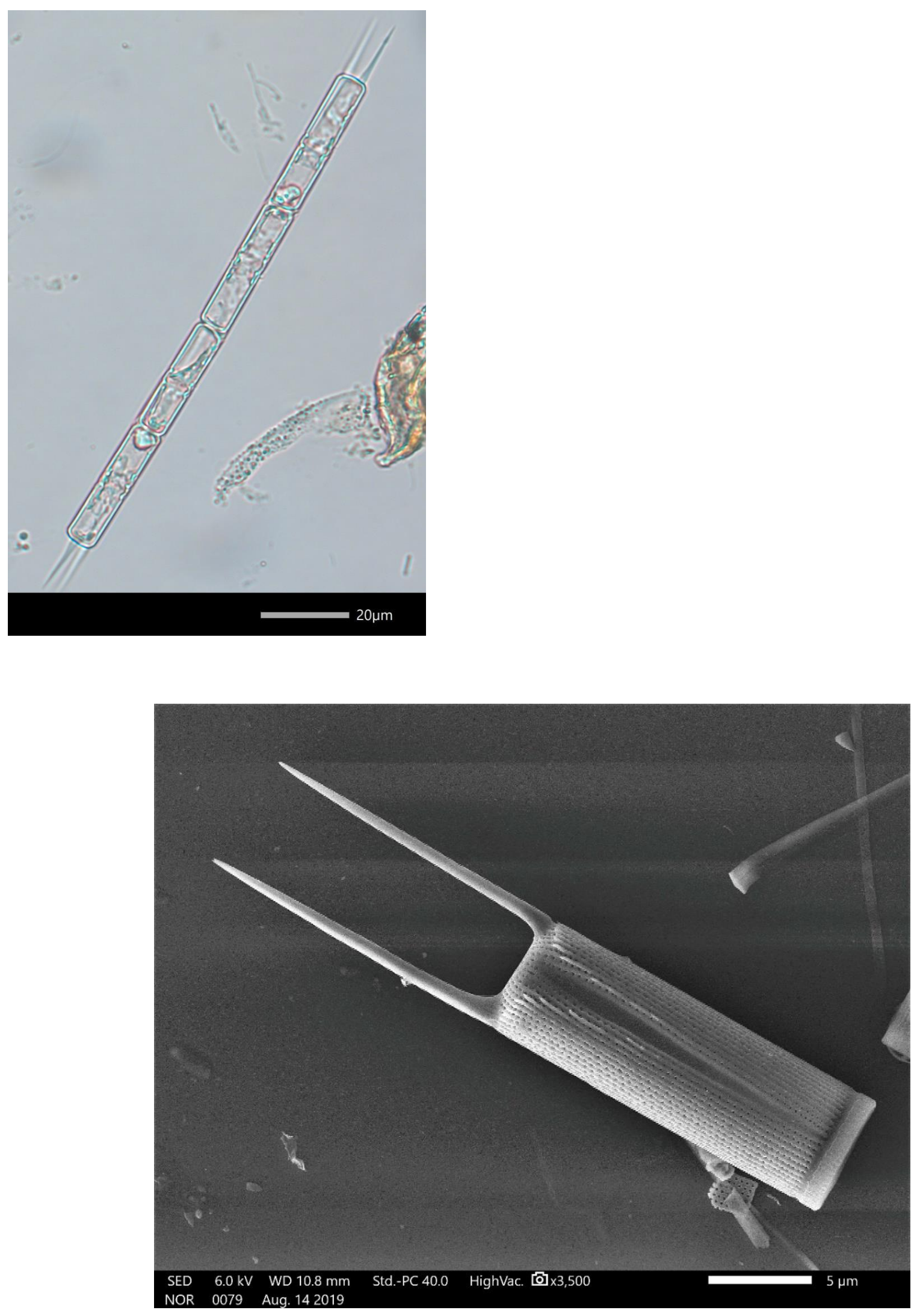
Aulacoseira tenella (Nygaard) Simonsen, 1979
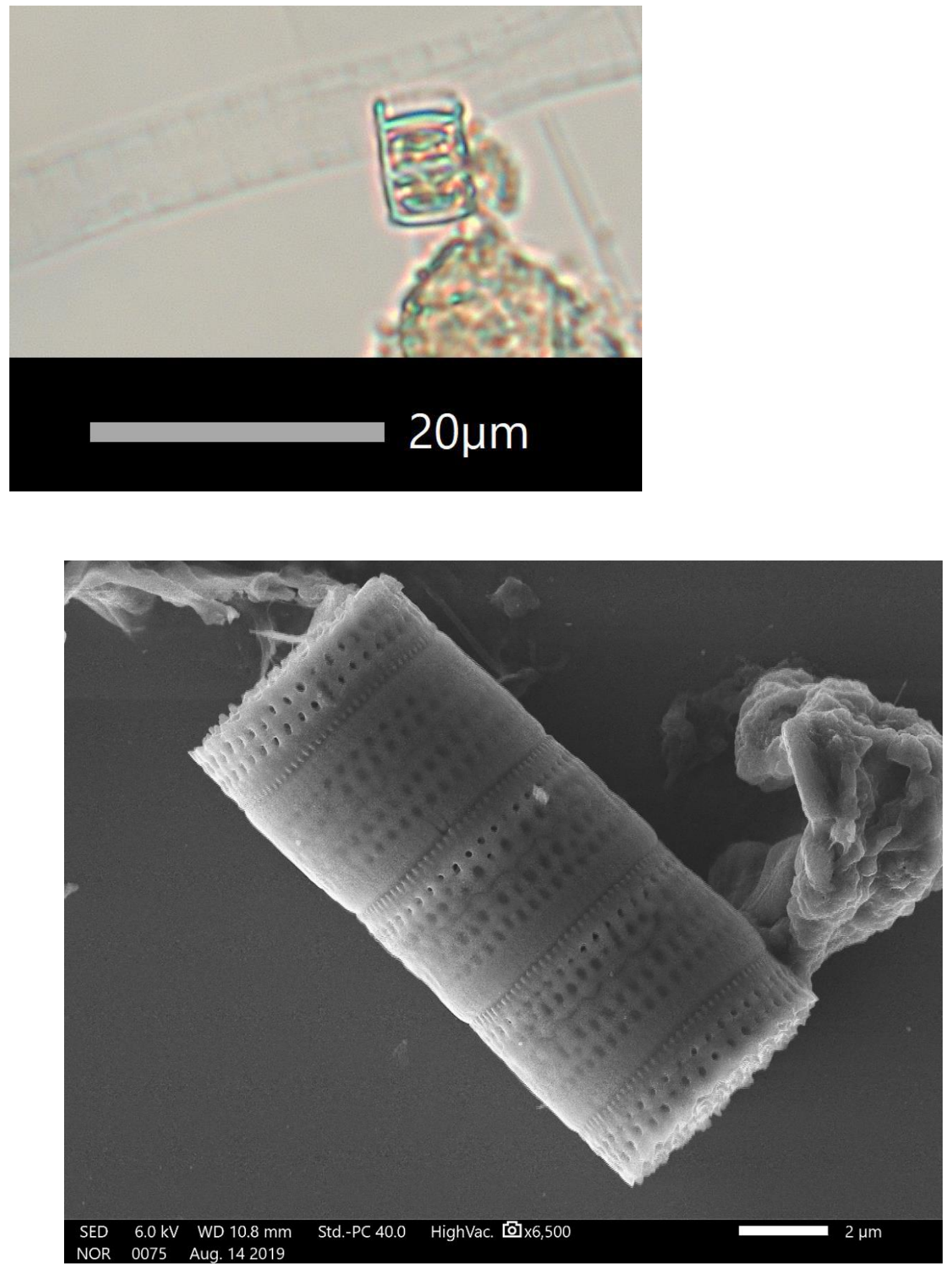
Aulacoseira coroniformis Pearce \& Cremer, 2010

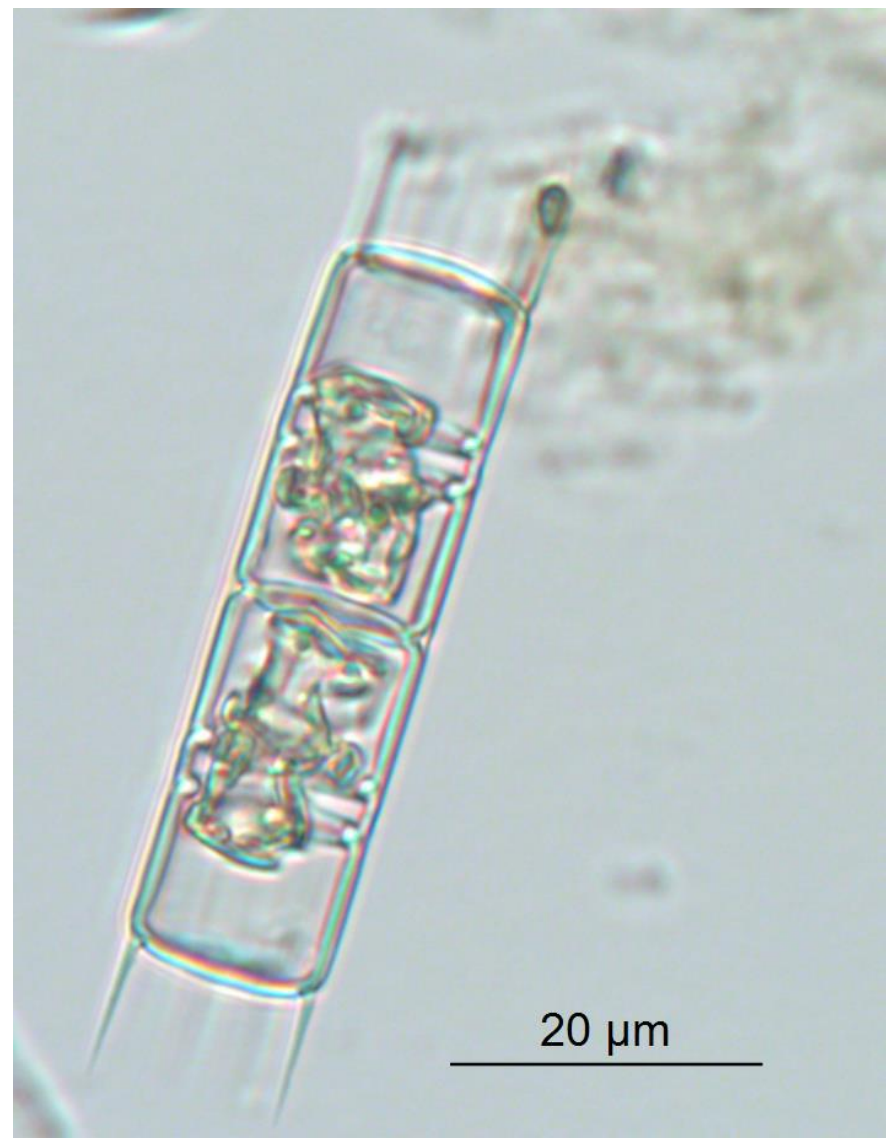

Brachysira cf. microcephala (Grunow) Compère, 1986

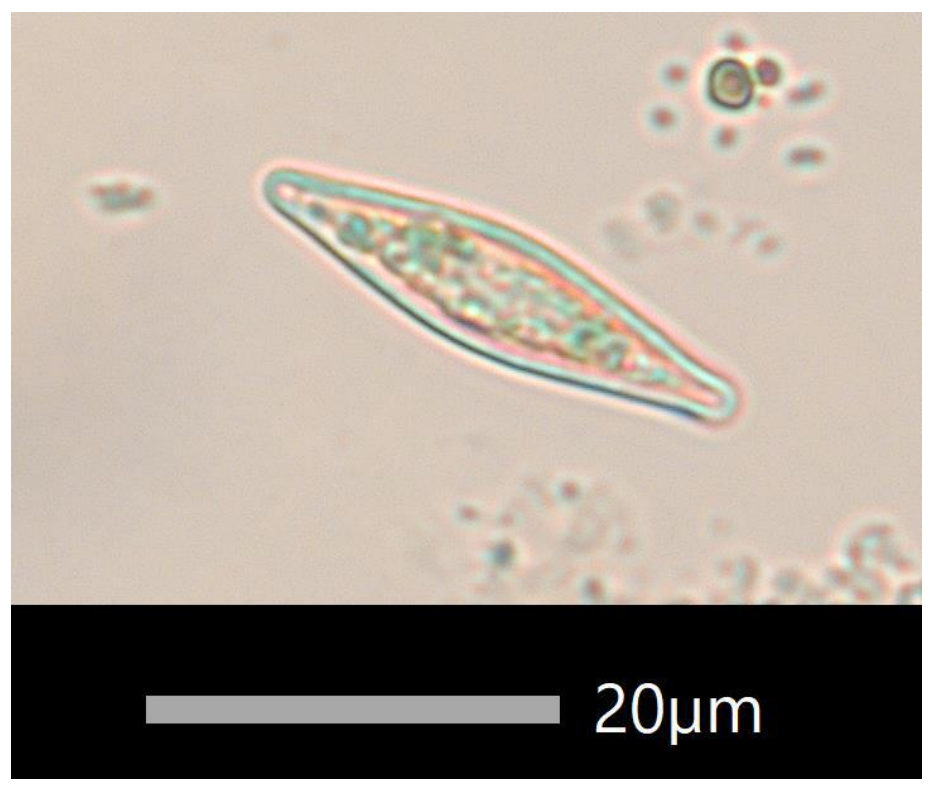


Brachysira serians (Brébisson) Round \& D.G. Mann, 1981

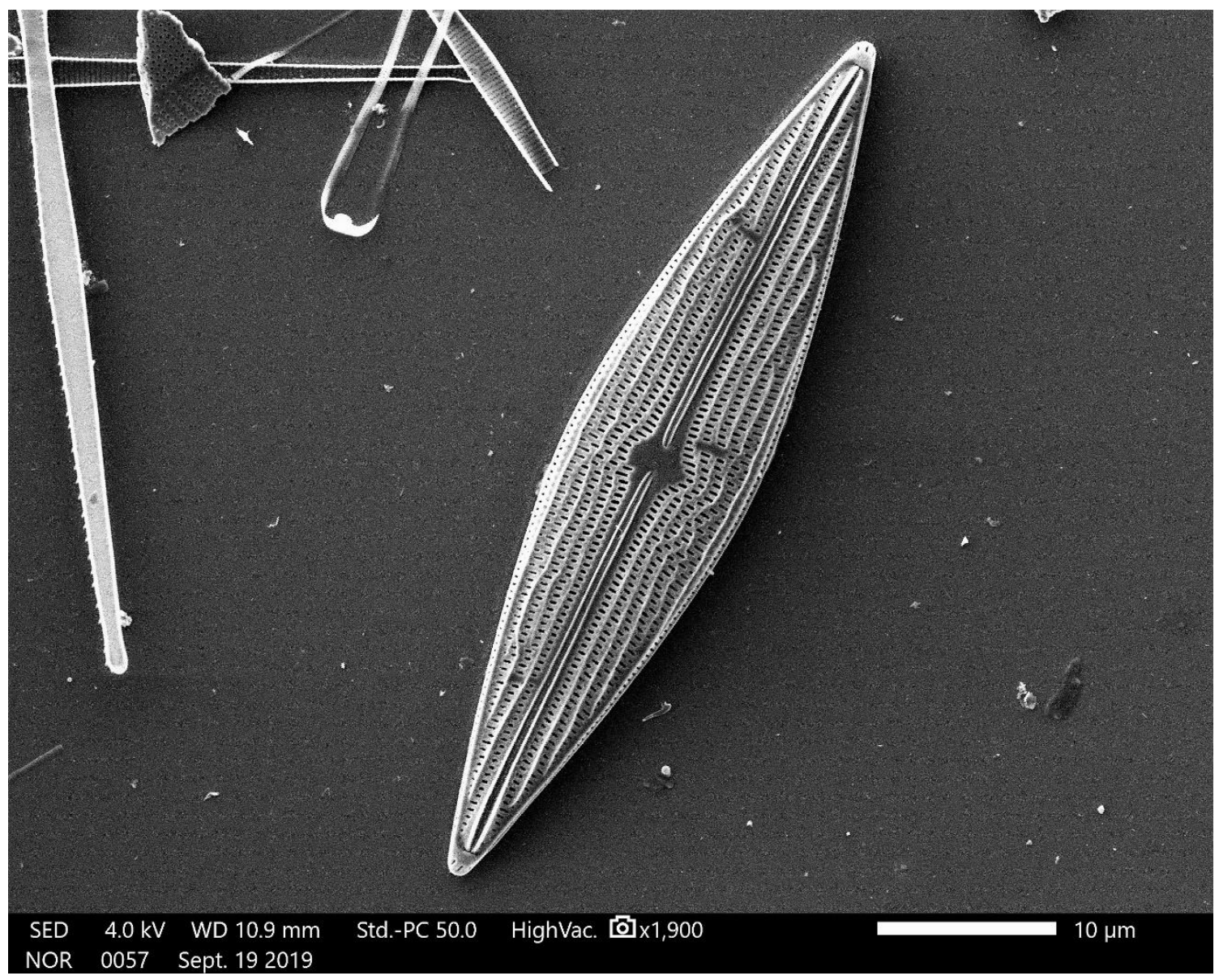

Encyonema lafc01 Kützing, 1833

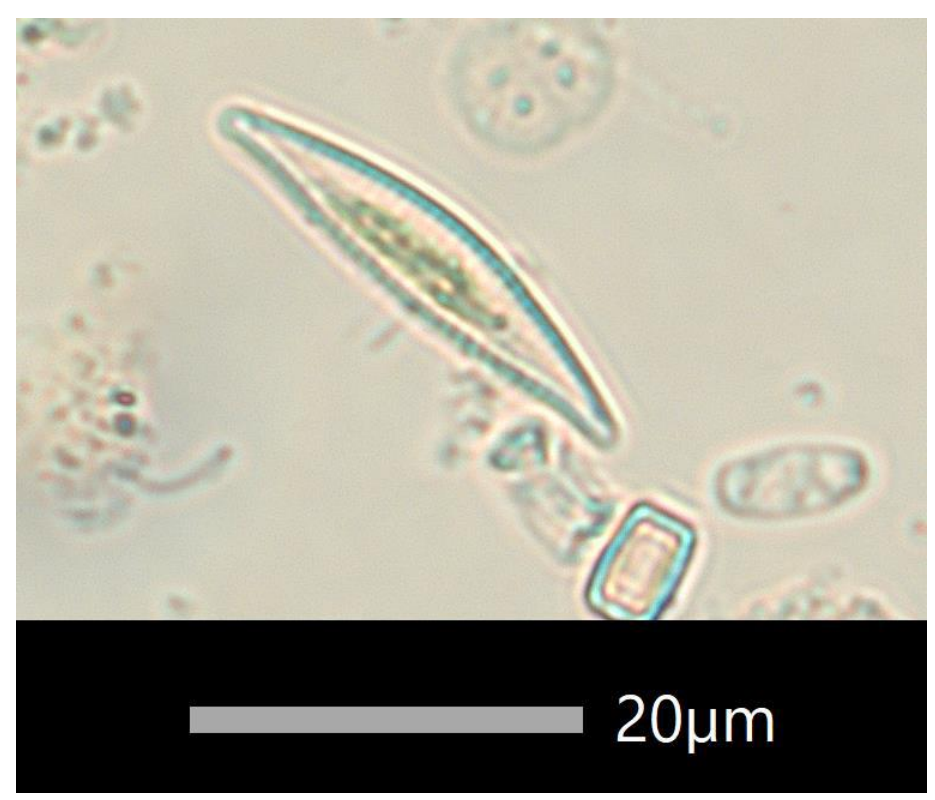


Encyonema lafc02 Kützing, 1833

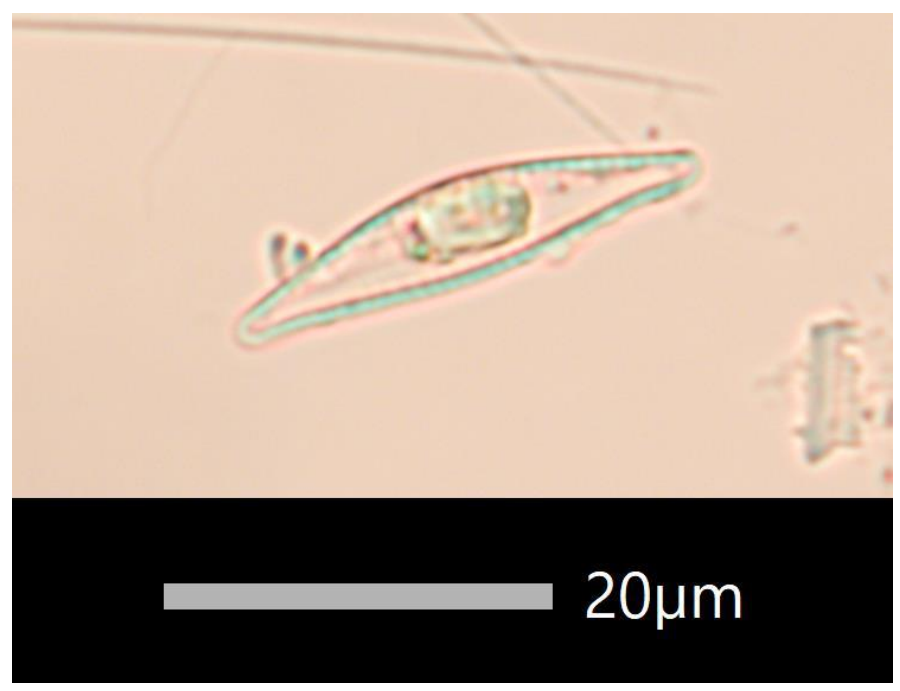

Eunotia carolina R.M. Patrick, 1958

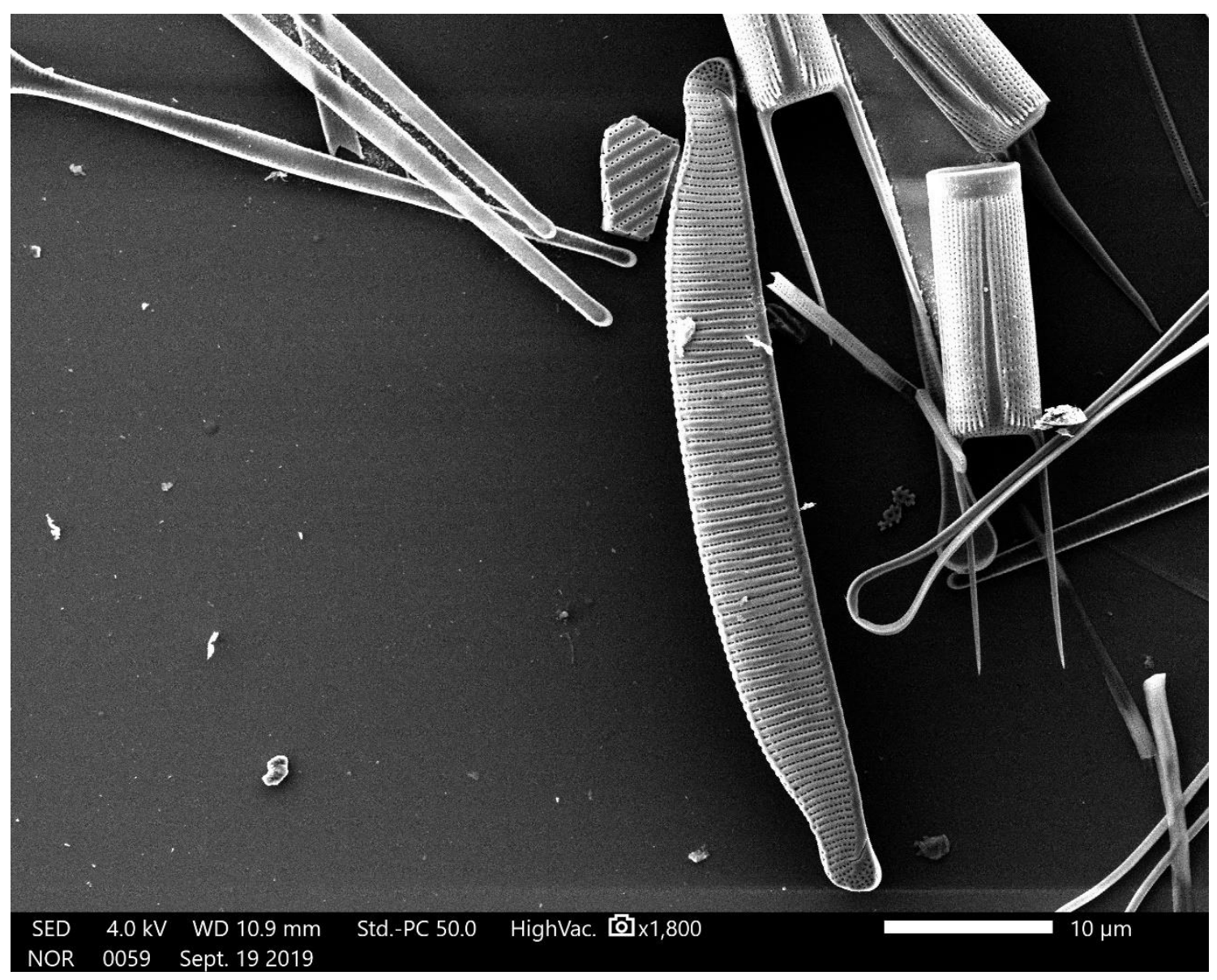


Eunotia diodon Ehrenberg, 1837

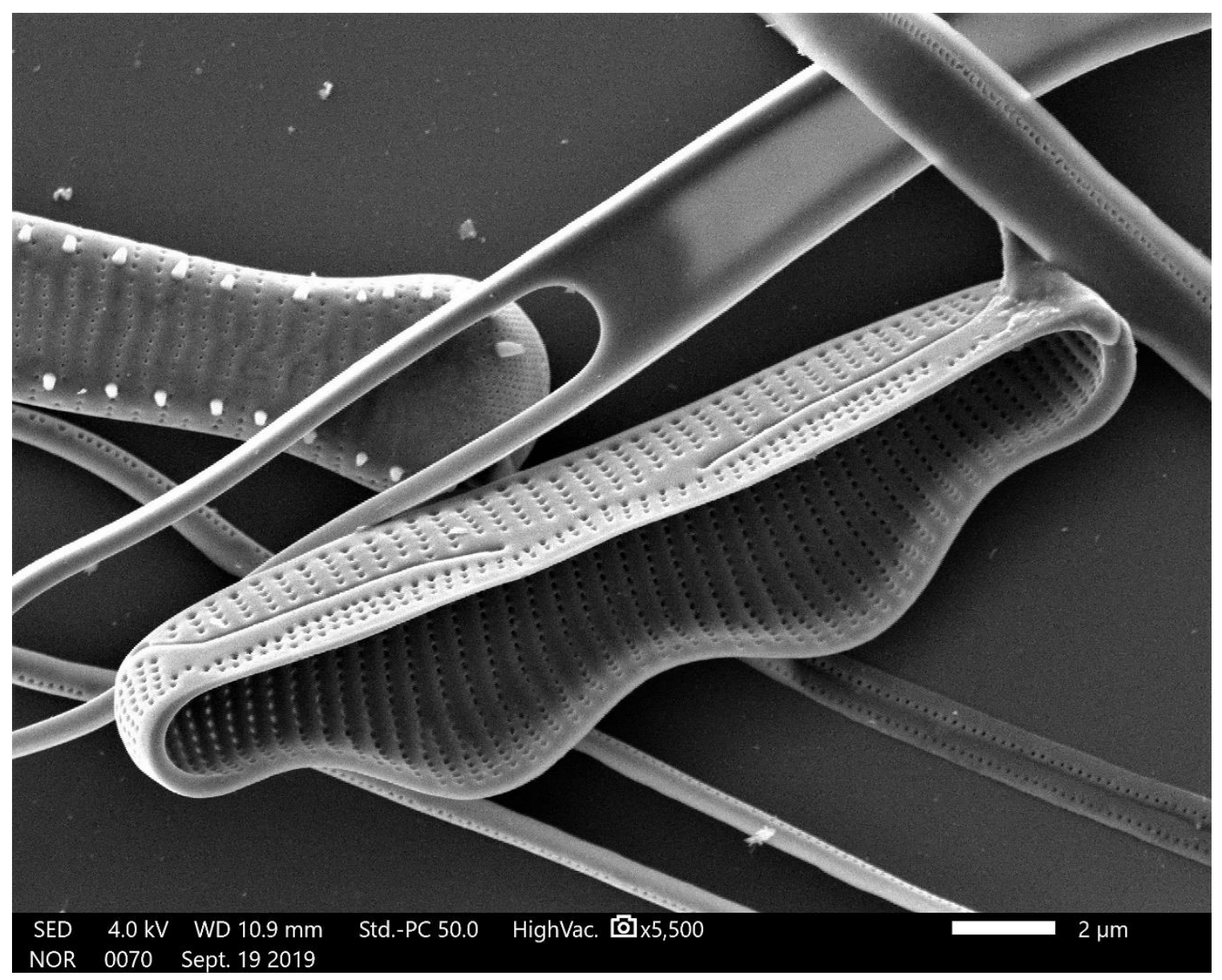


Eunotia flexuosa (Brébisson ex Kützing) Kützing, 1849
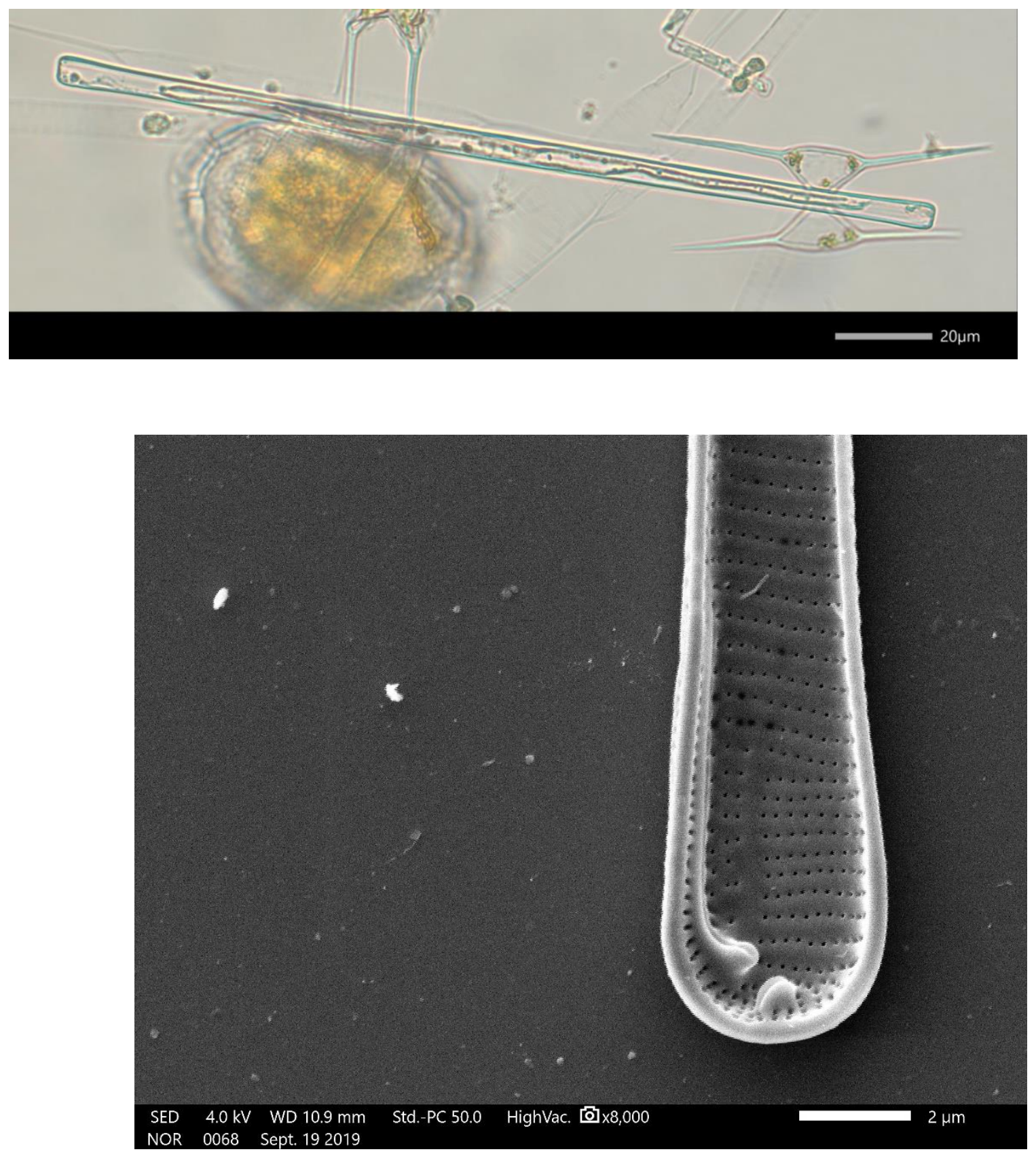
Eunotia zasuminensis (Cabejszekówna) Körner, 1970
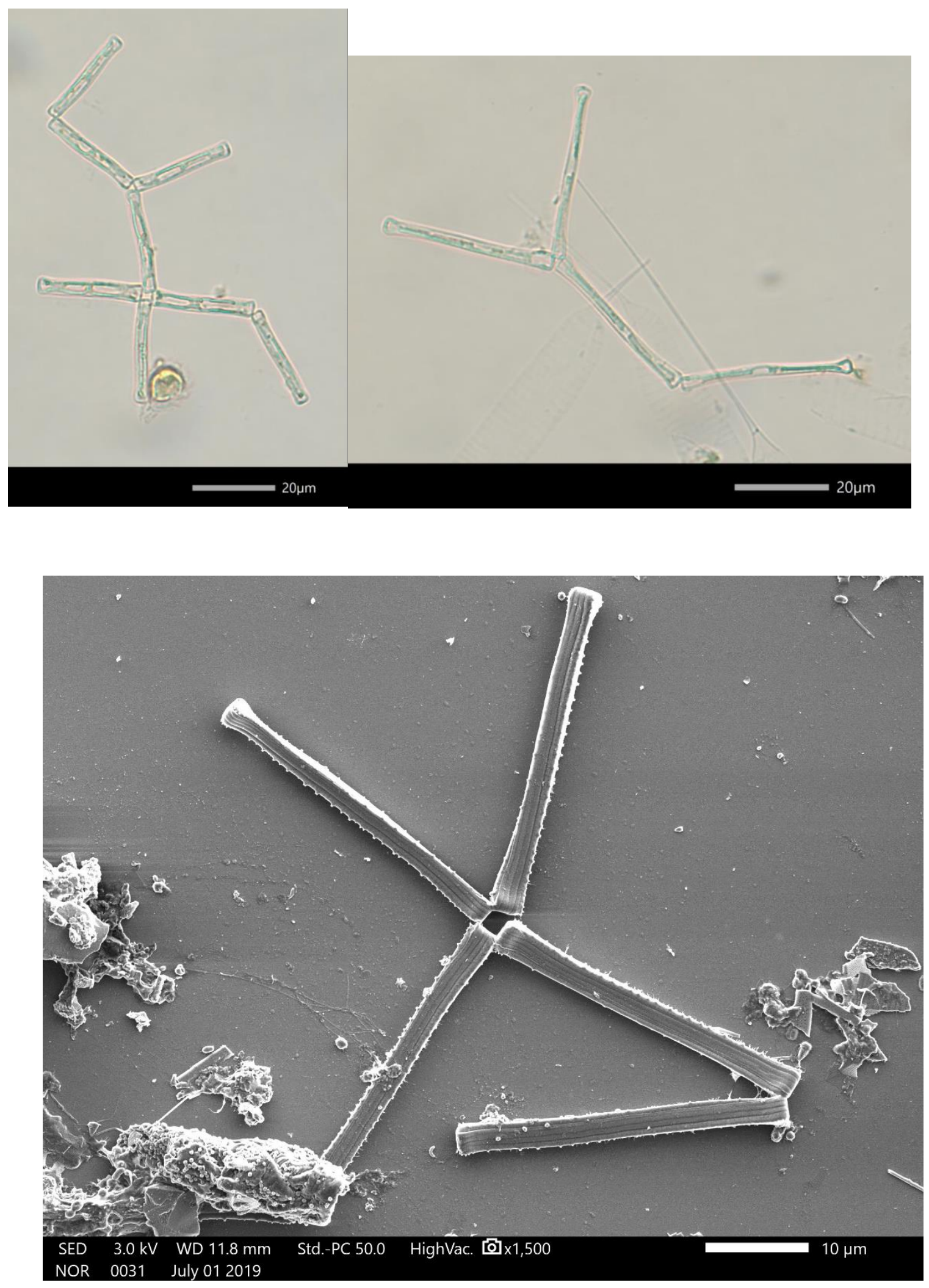
Frustulia crassinervia (Brébisson ex W. Smith) Lang-Bertalot \& Krammer, 1996

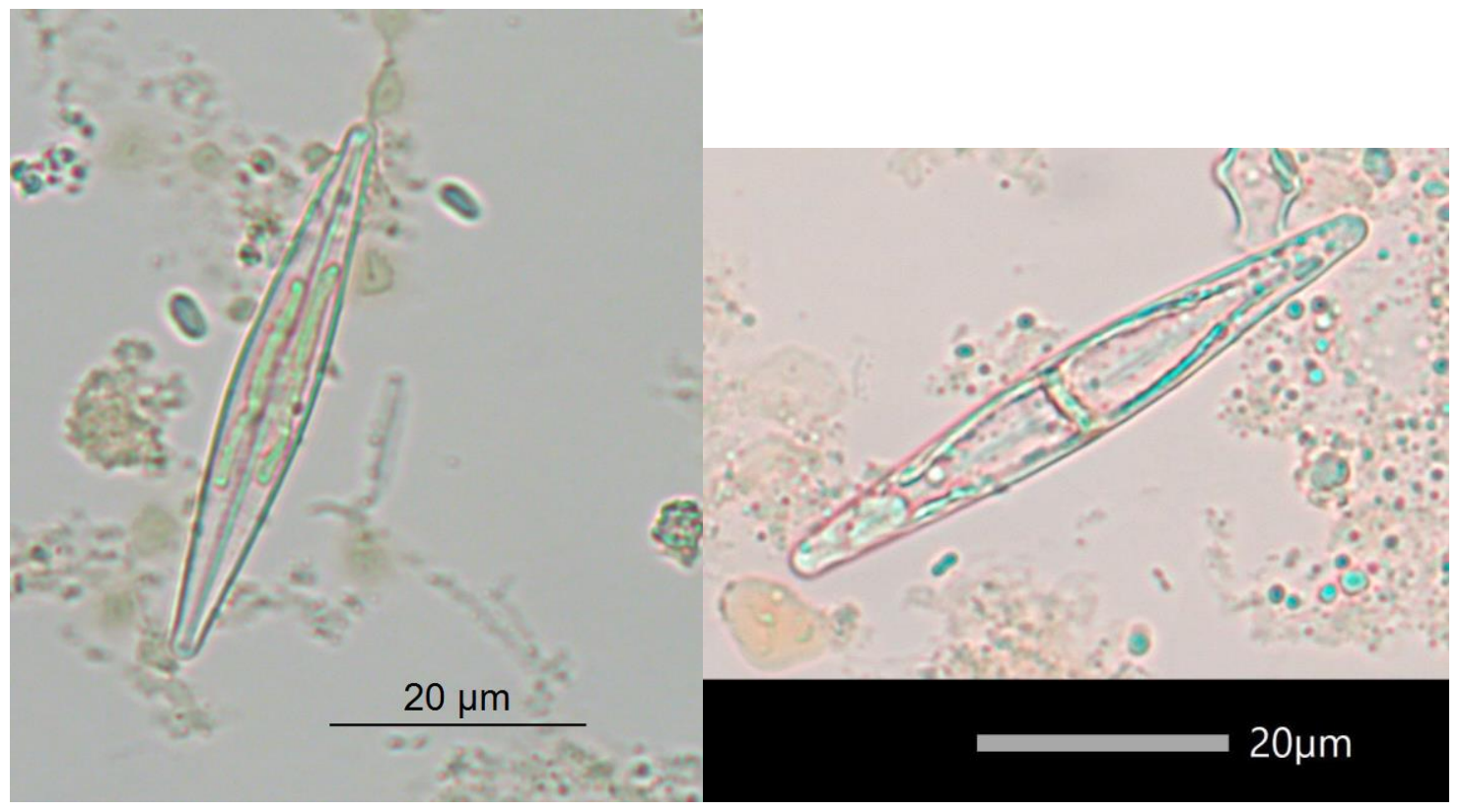

Frustulia pseudomagaliesmontana K.E. Camburn \& D.F. Charles, 2000

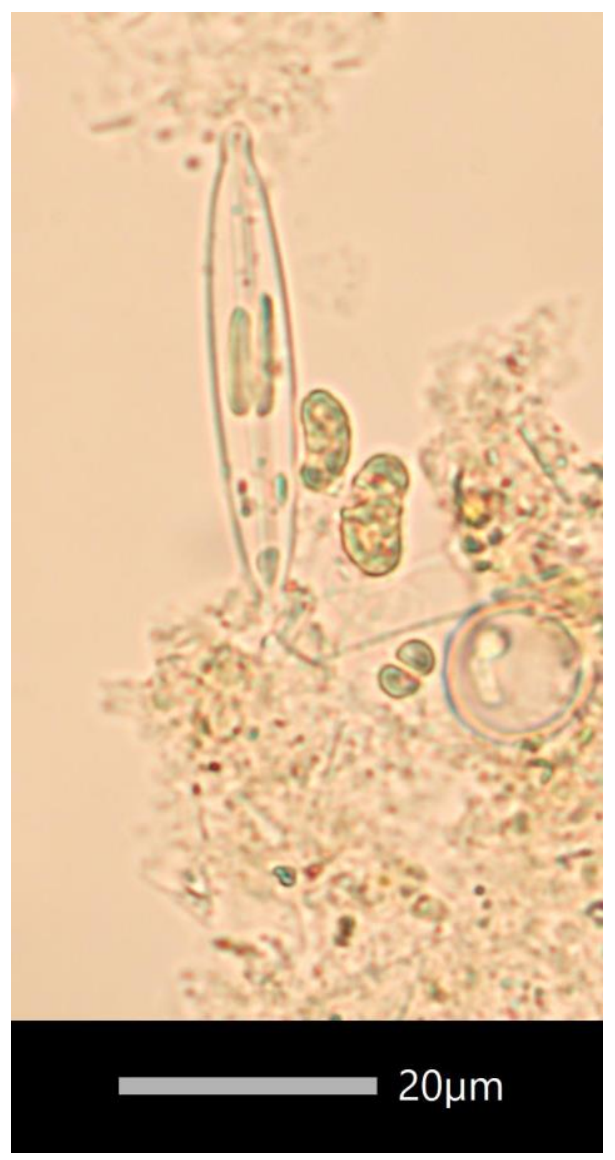


Frustulia saxonica Rabenhorst, 1853
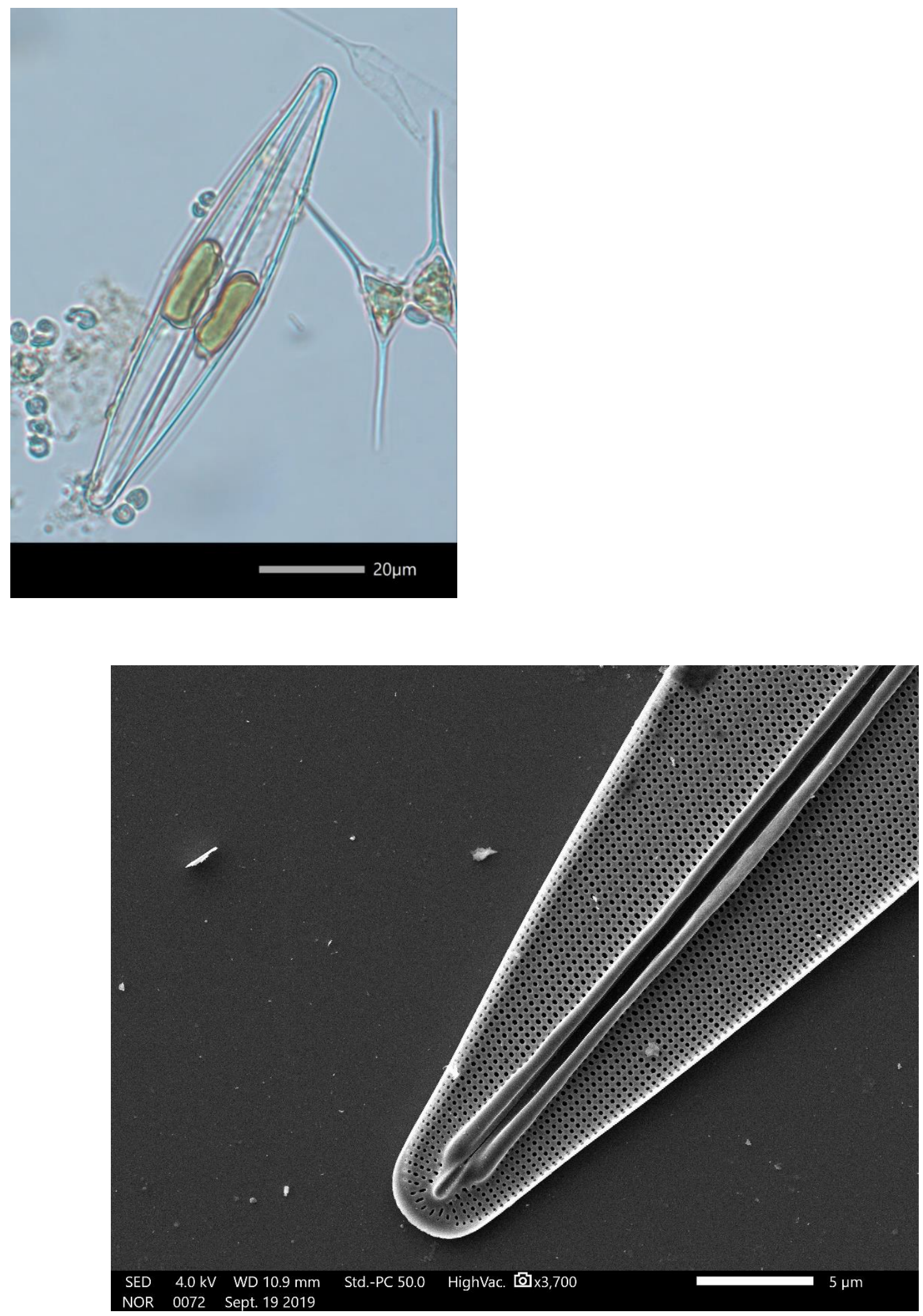
Fragilaria cf. sepes Ehrenberg, 1854

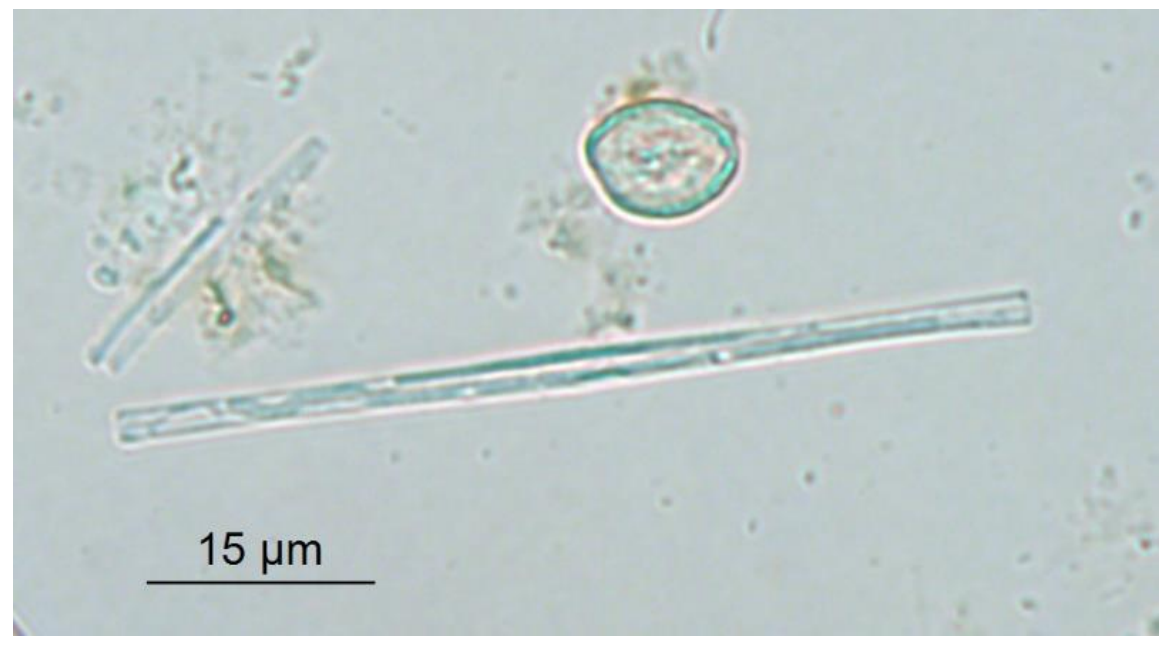

Iconella cuspidata (Hustedt, 1942) D. Kapustin \& Kulikovskiy, 2018

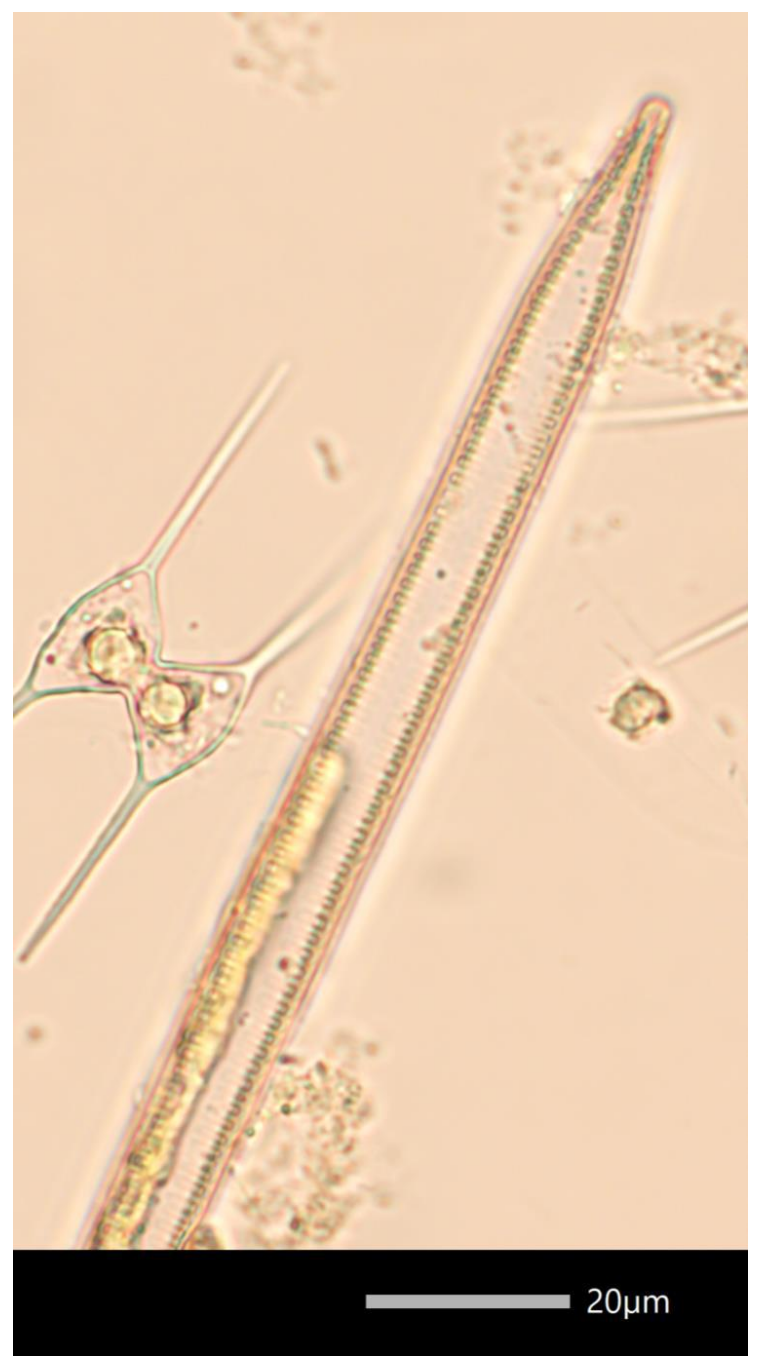


Iconella linearis (W. Smith) Ruck \& Nakov, 2016

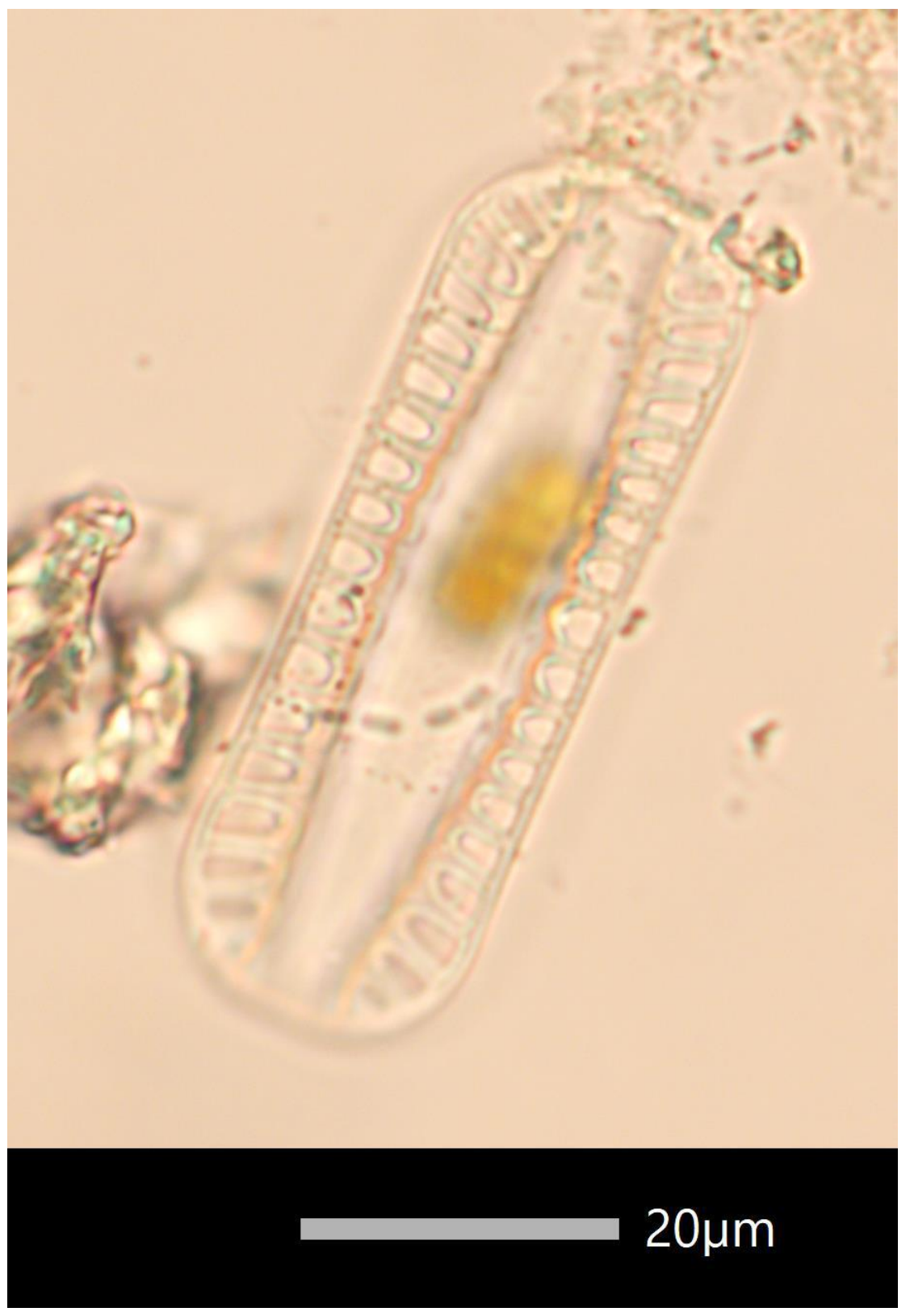


Iconella linearis $f$. constricta (W. Smith) Ruck \& Nakov, 2016

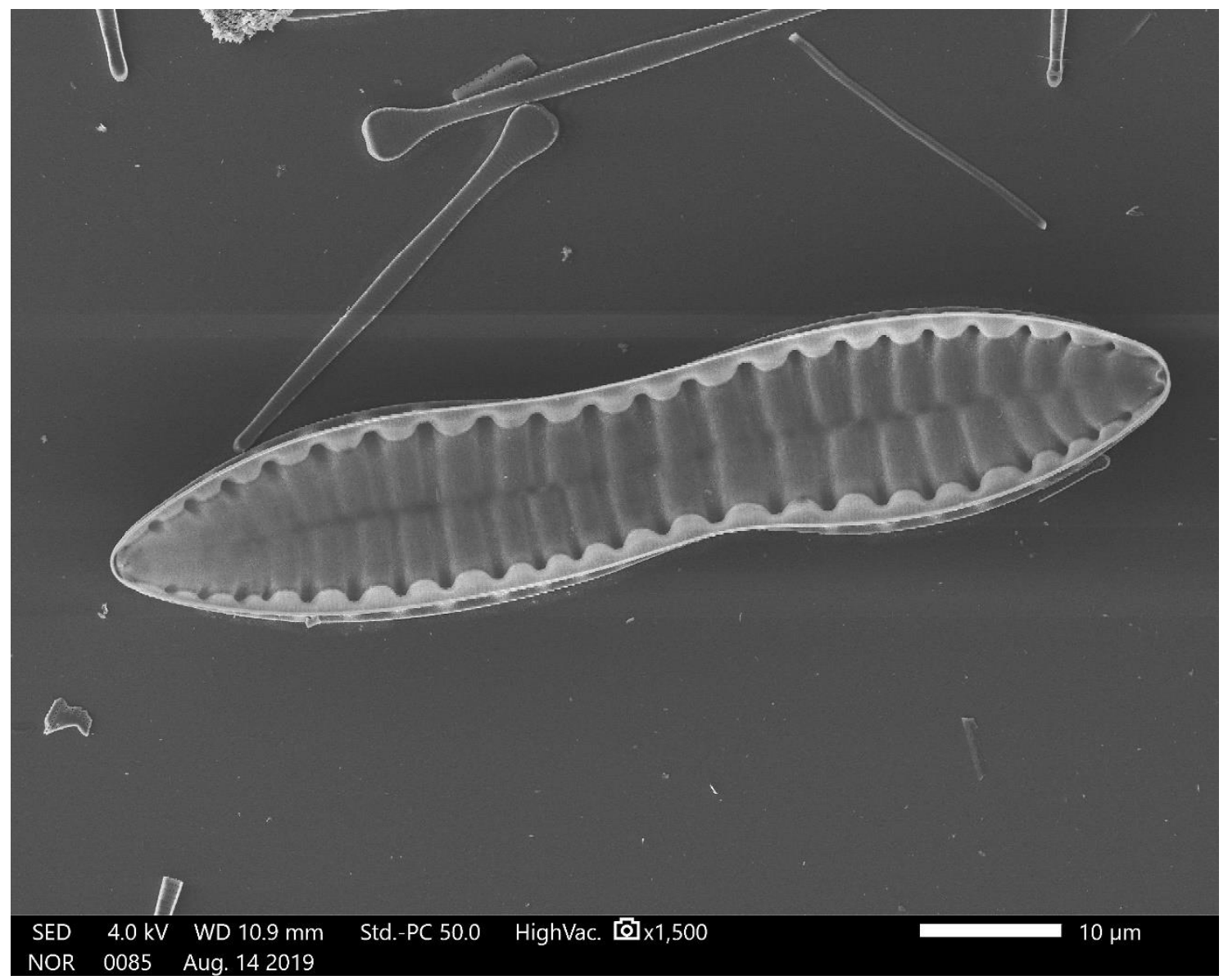

Lemincola exigua (Grunow) Kulikovskiy, Witkowski \& Plinski, 2011

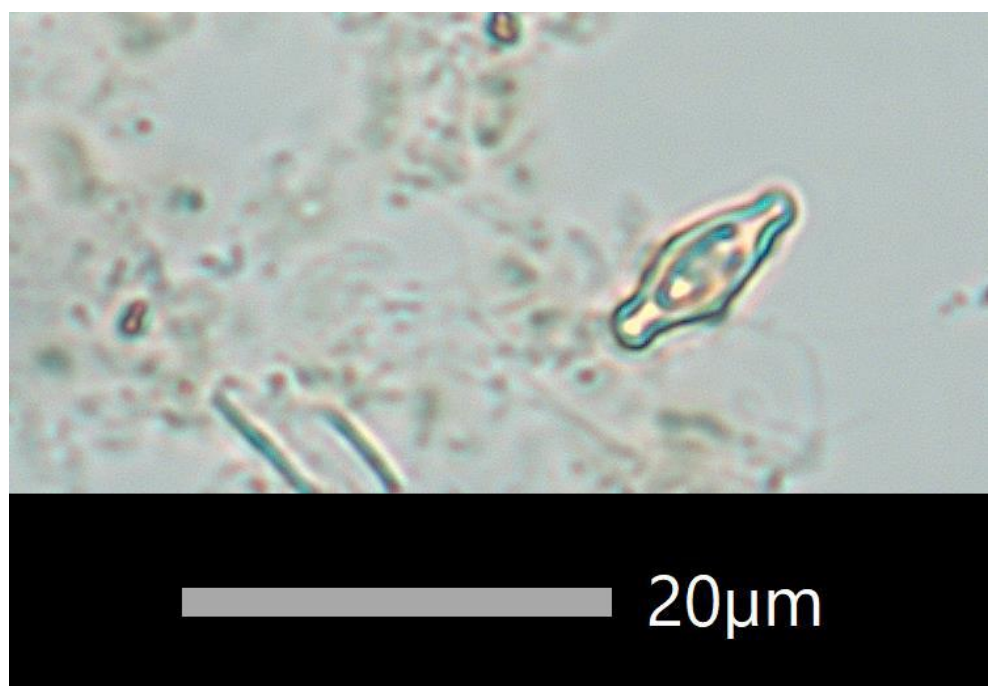


Mastogloia cocconeiformis Grunow, 1860

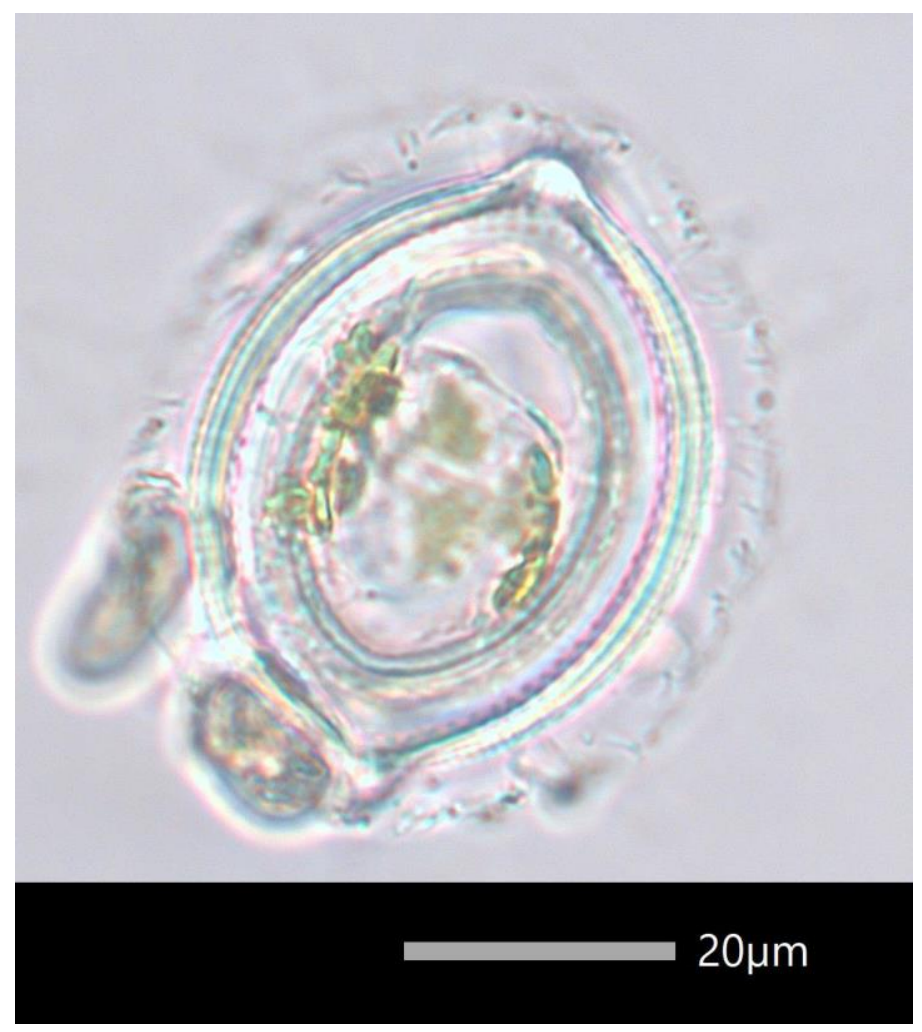

Navicula spp. Bory de Saint-Vincent, 1822

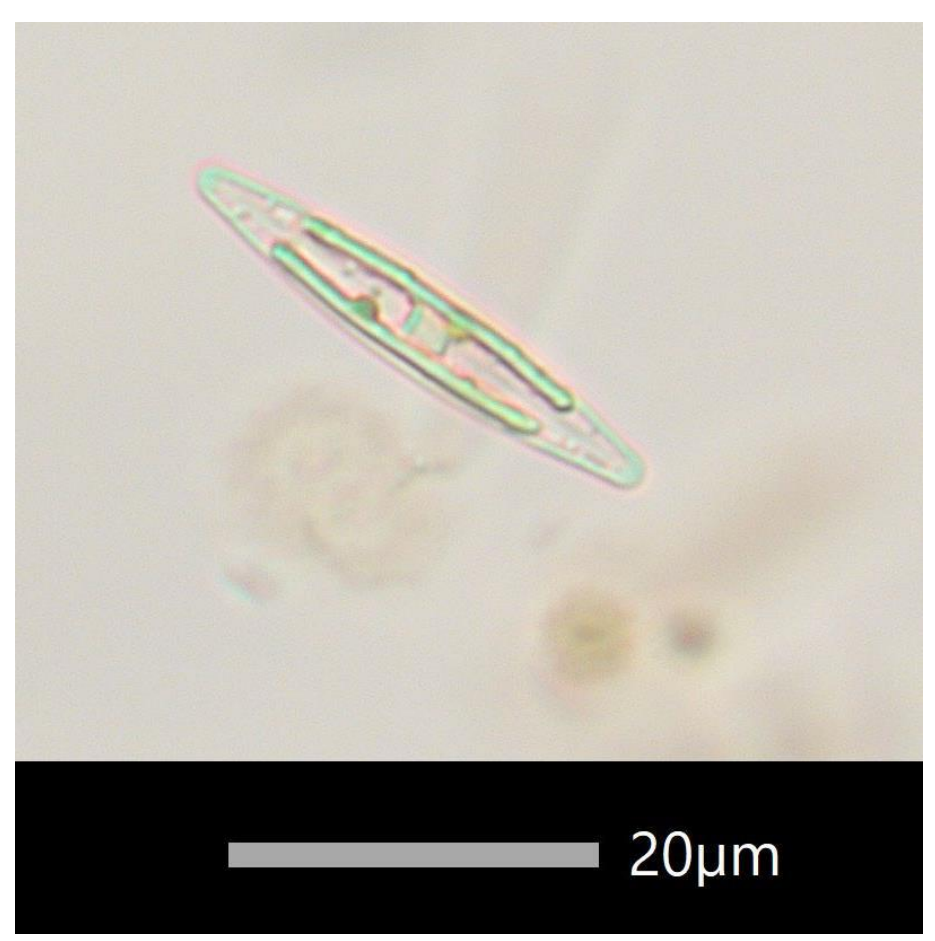


Neidium ampliatum (Ehrenberg) Krammer, 1985

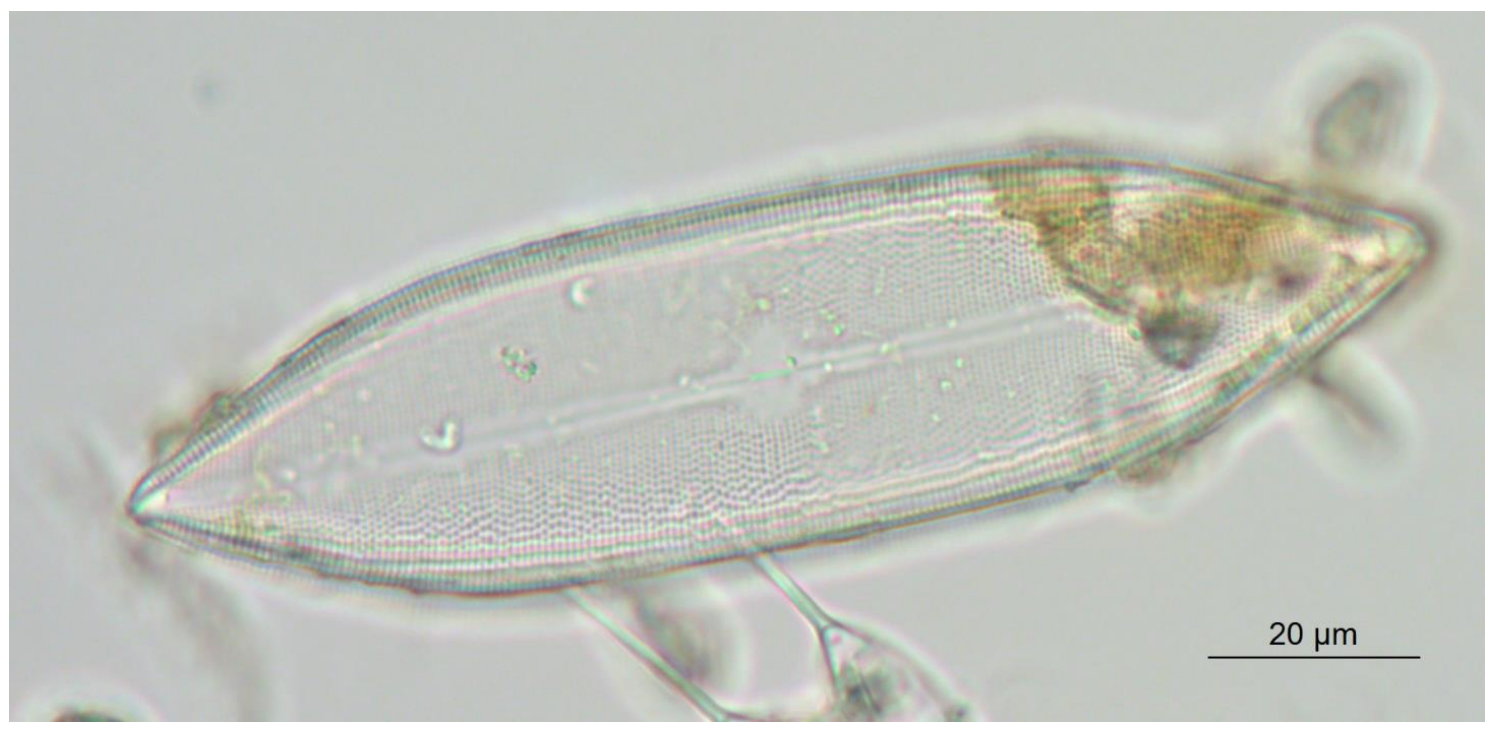


Neidium densestriatum (Østrup) Krammer, 1985
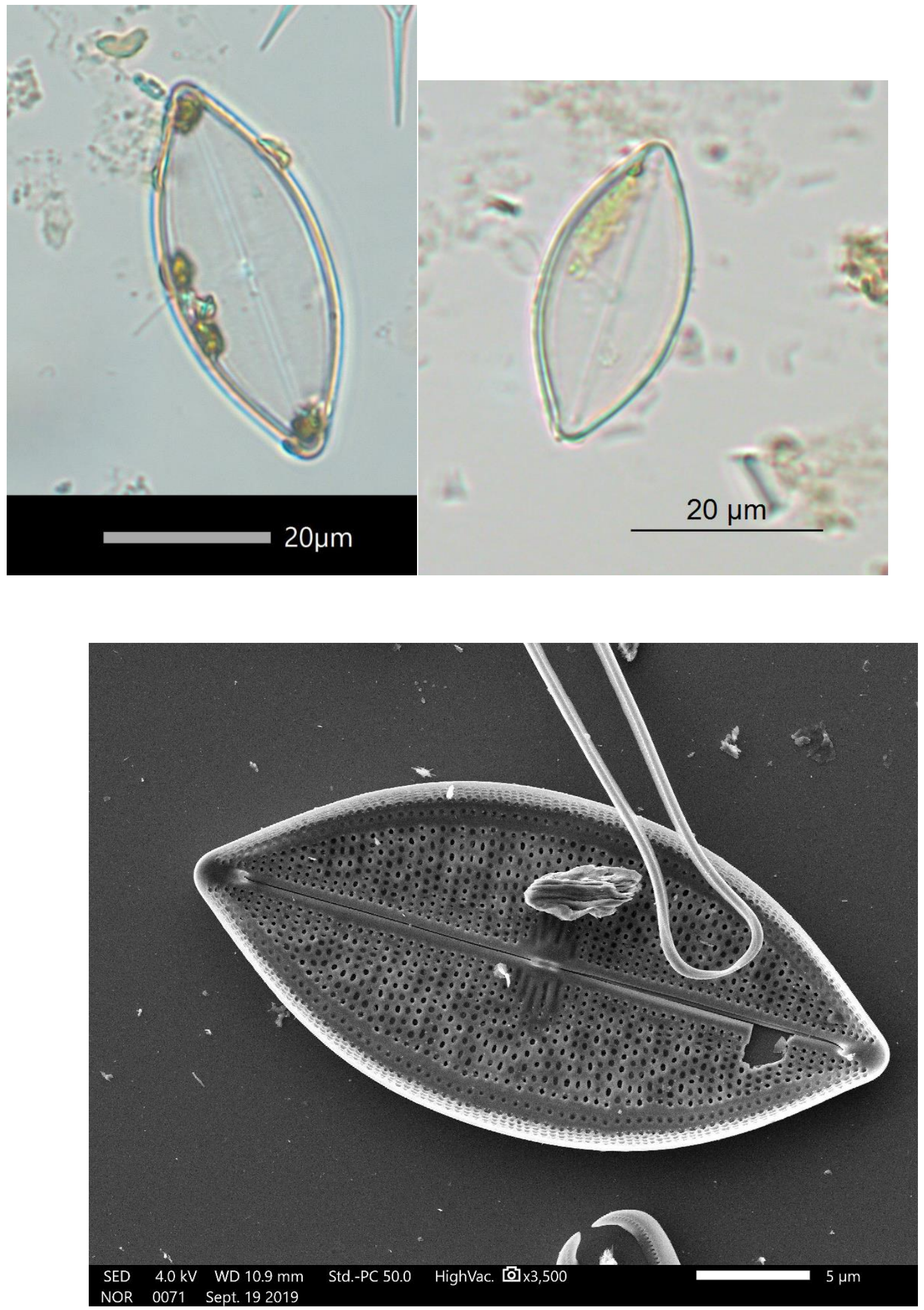
Pinnularia brauniana (Grunow) Sudnicka, 1888

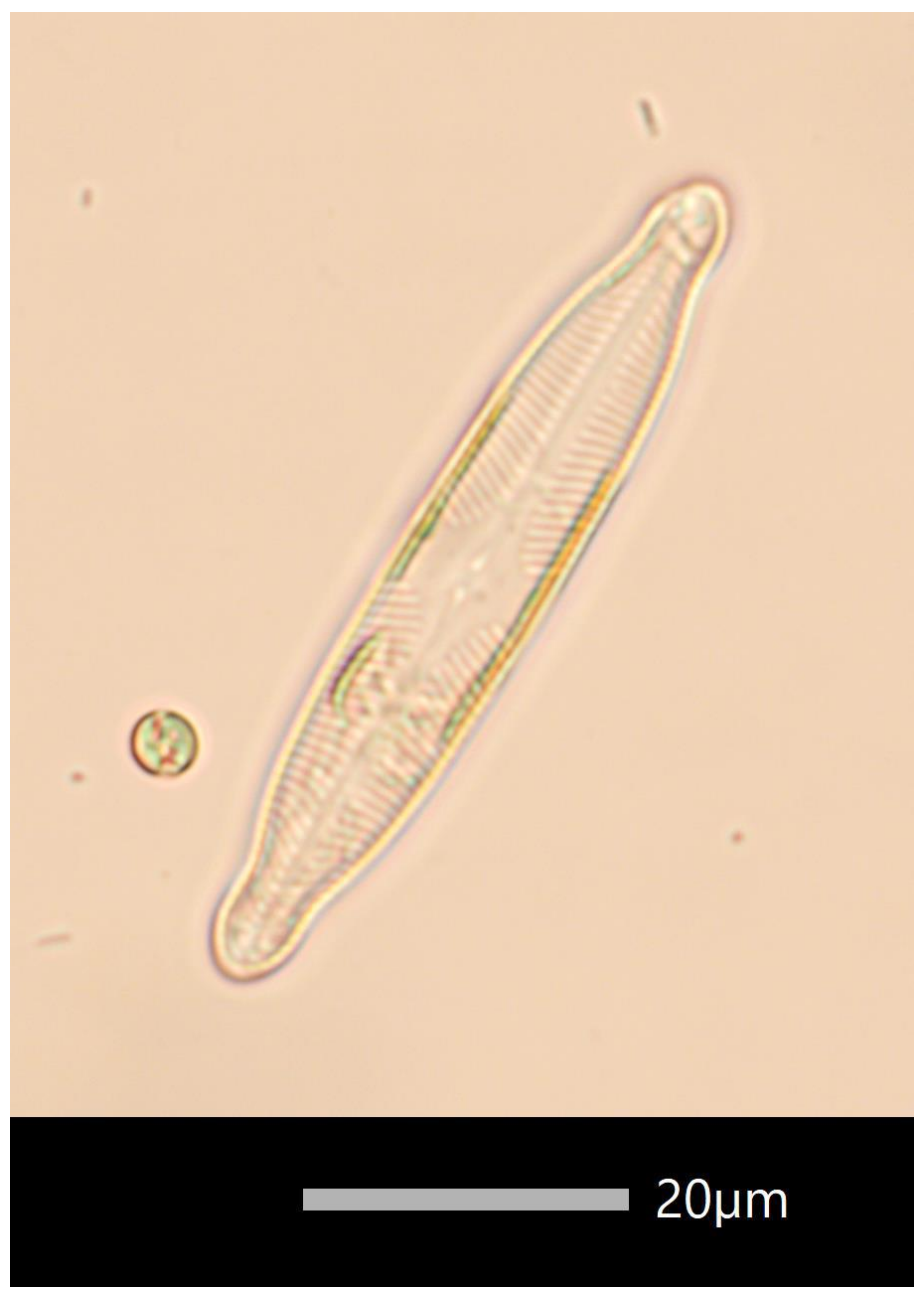


Tabellaria flocculosa (Roth) Kützing, 1844
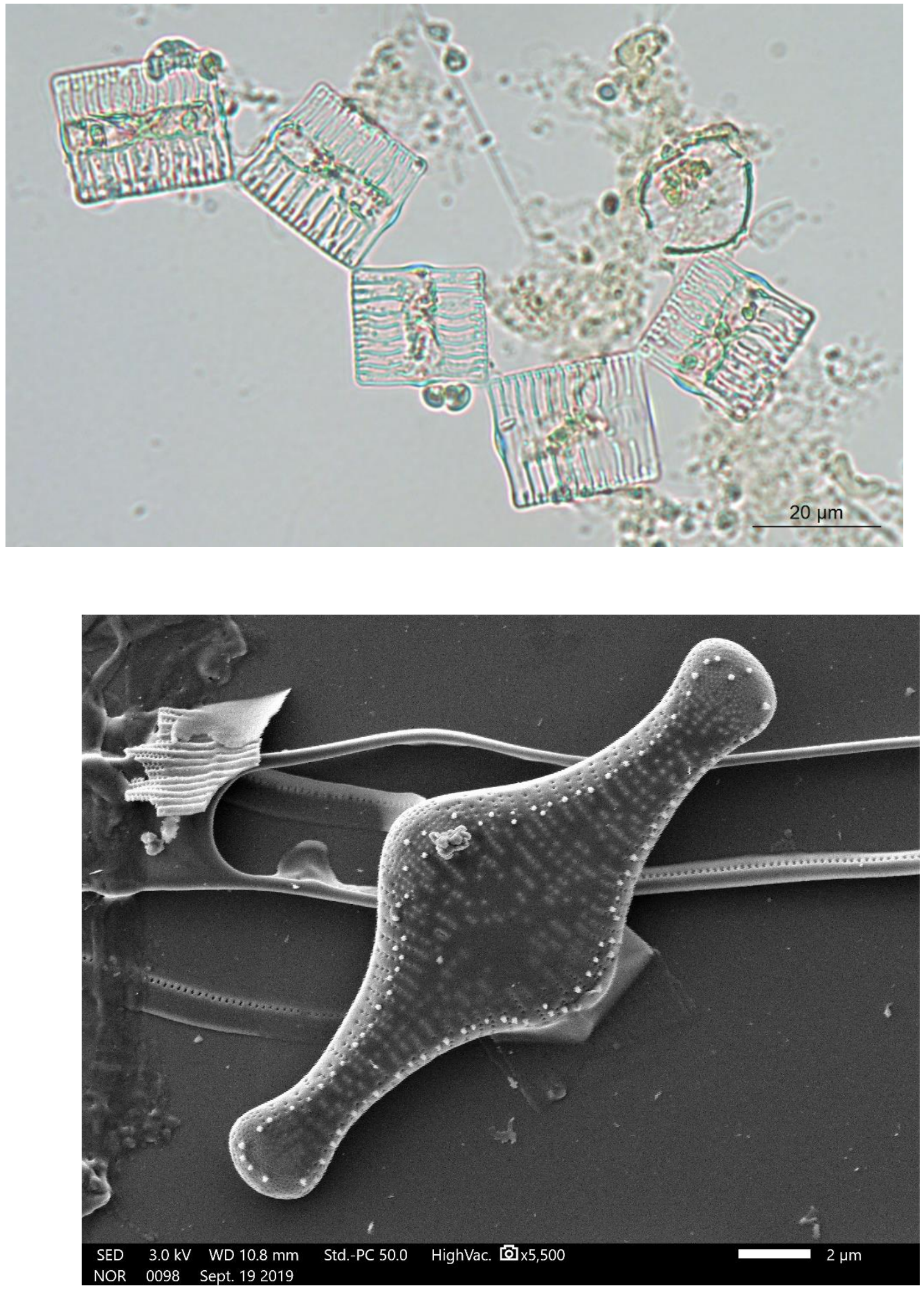
Tabellaria flocculosa v. linearis J.D. Koppen, 1975

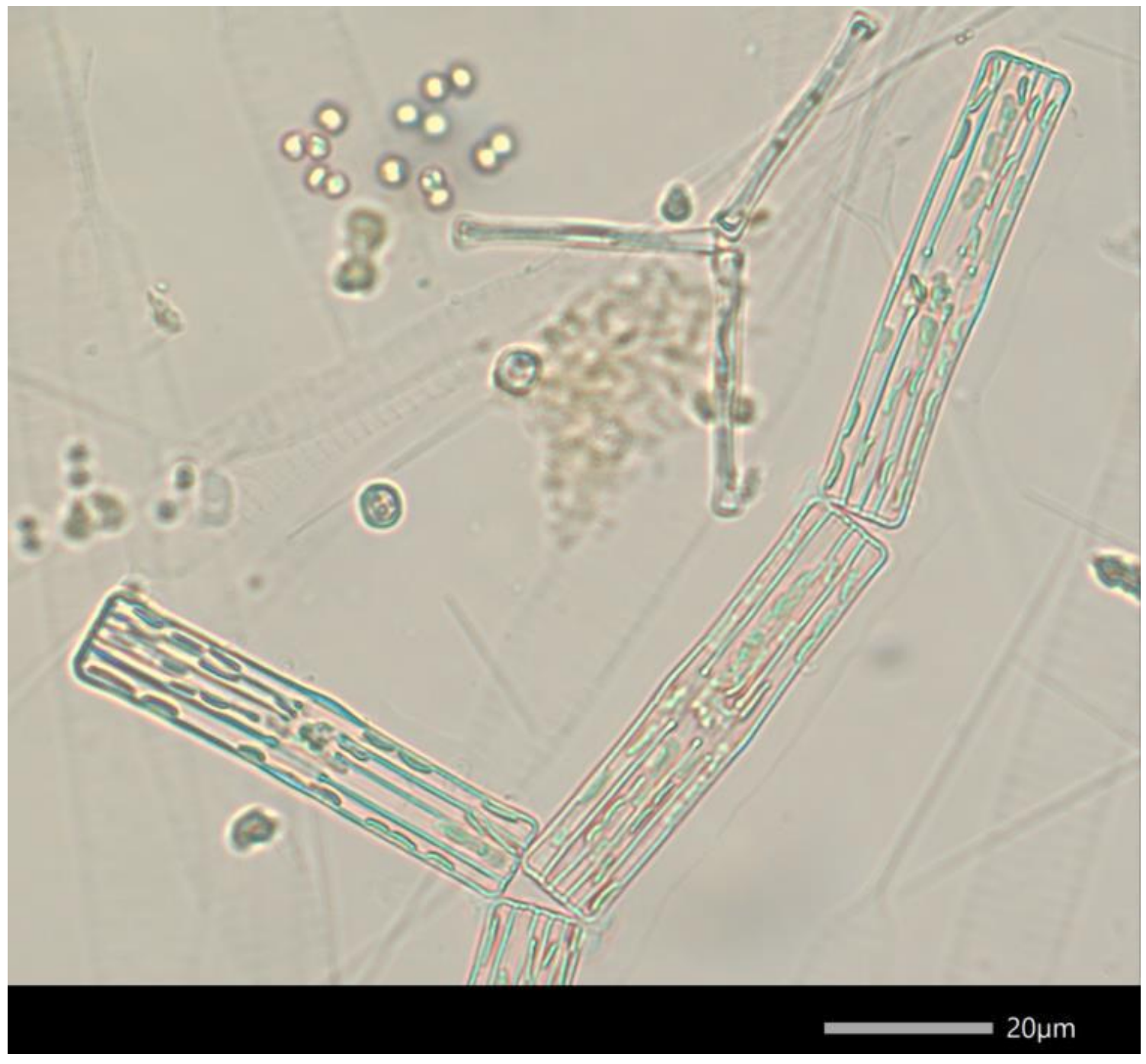


Urosolenia spp. Round \& R.M. Crawford, 1990
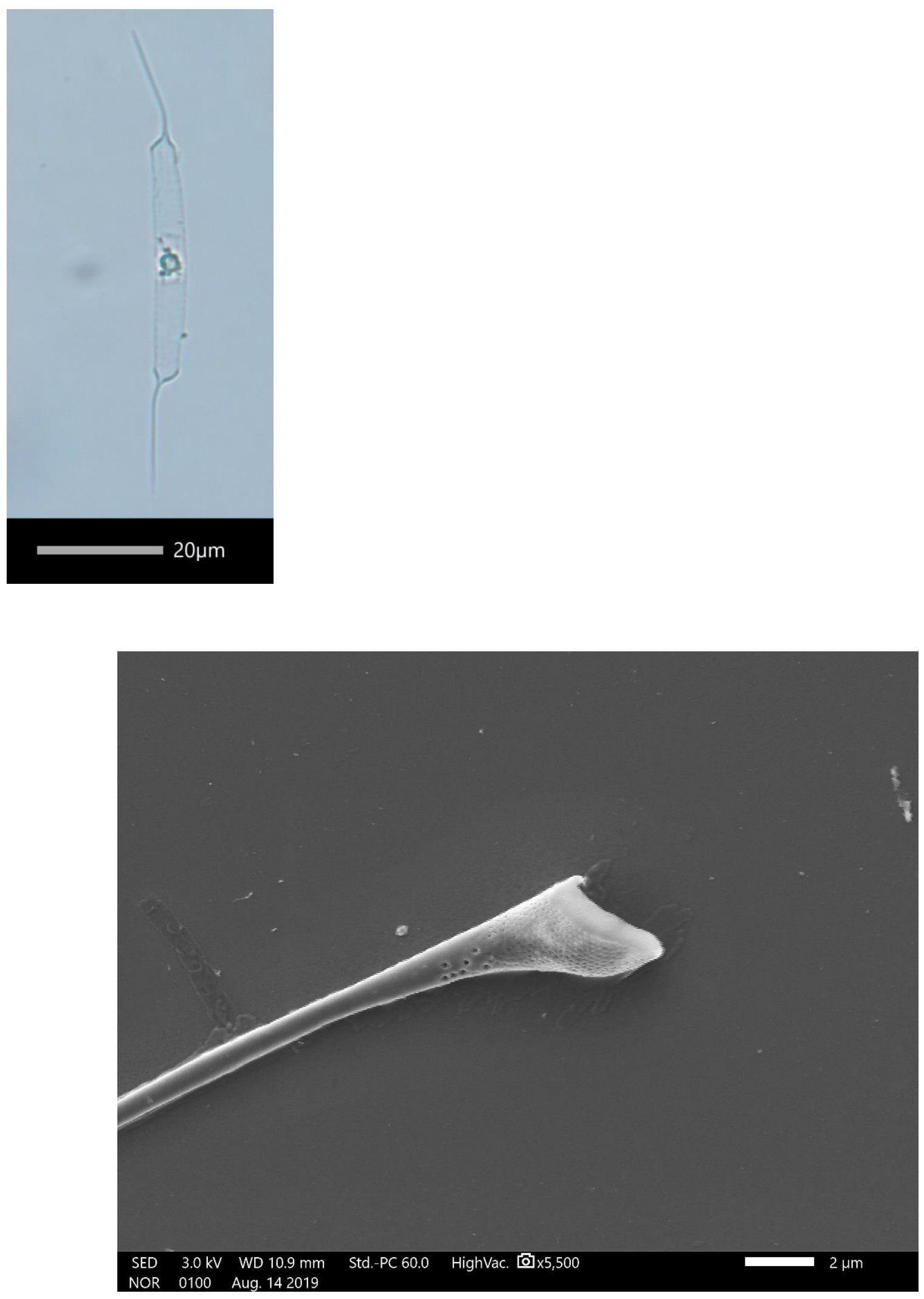
Urosolenia spp. (wide morph) Round \& R.M. Crawford, 1990
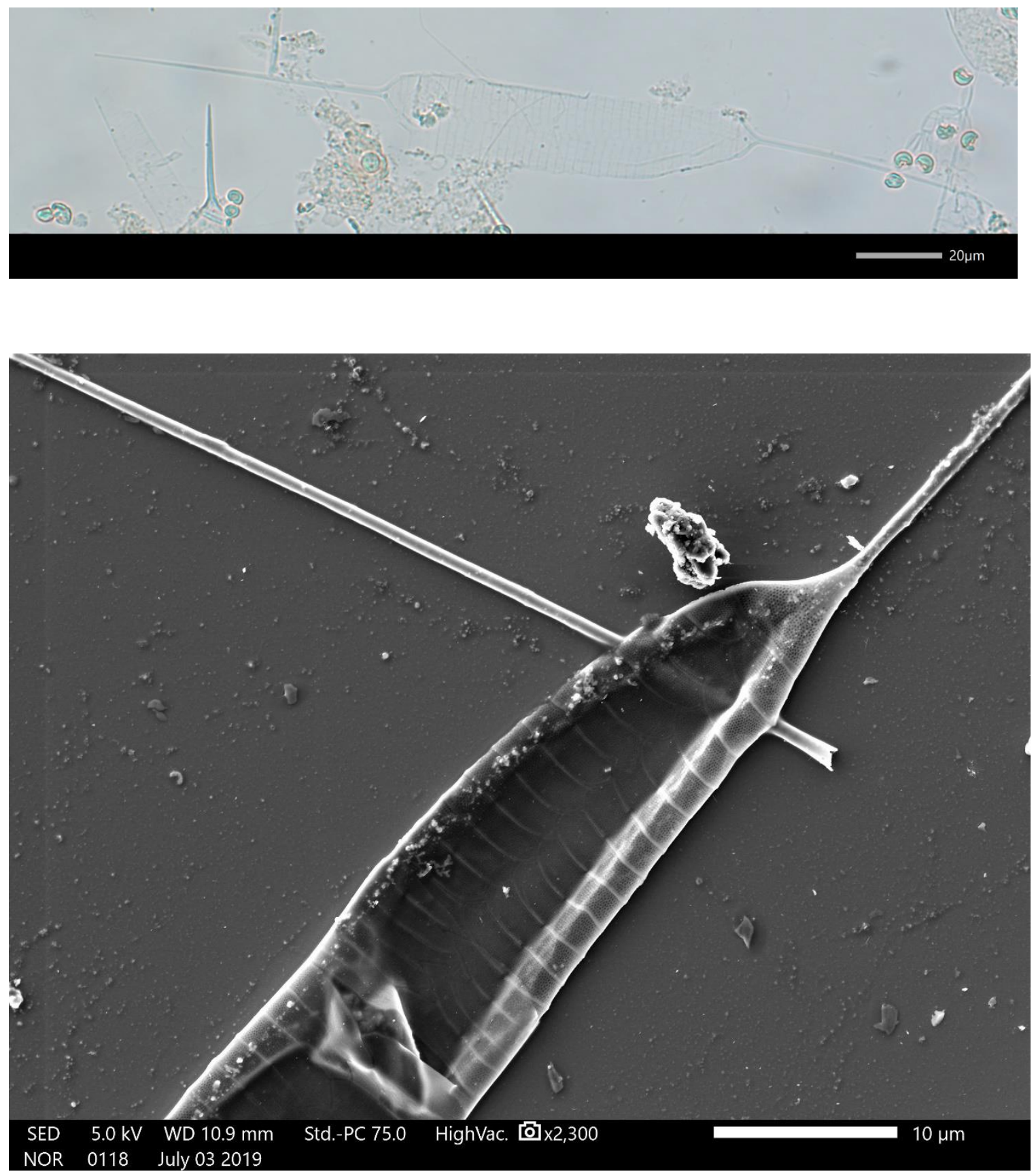


\section{Charophyta}

Actinotaenium cf. rufescens (Cleve) Teiling, 1954

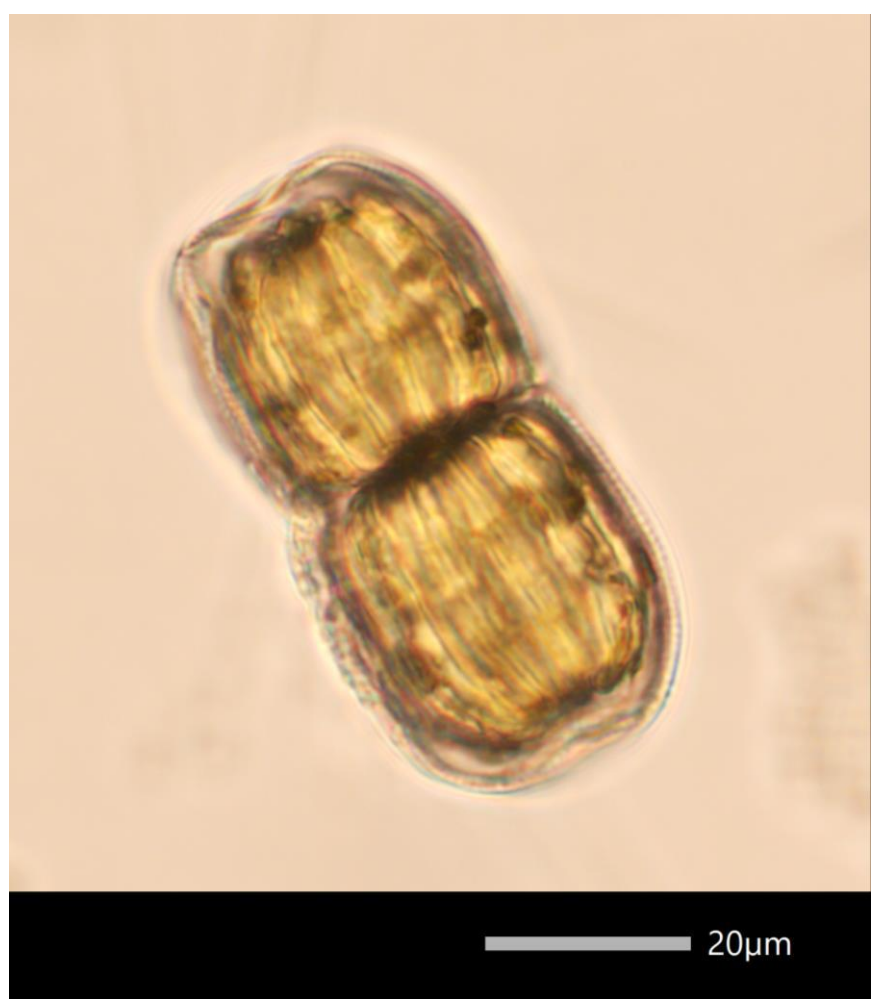

Bambusina brebissonii f. constricta A.M. Scott \& Prescott, 1961

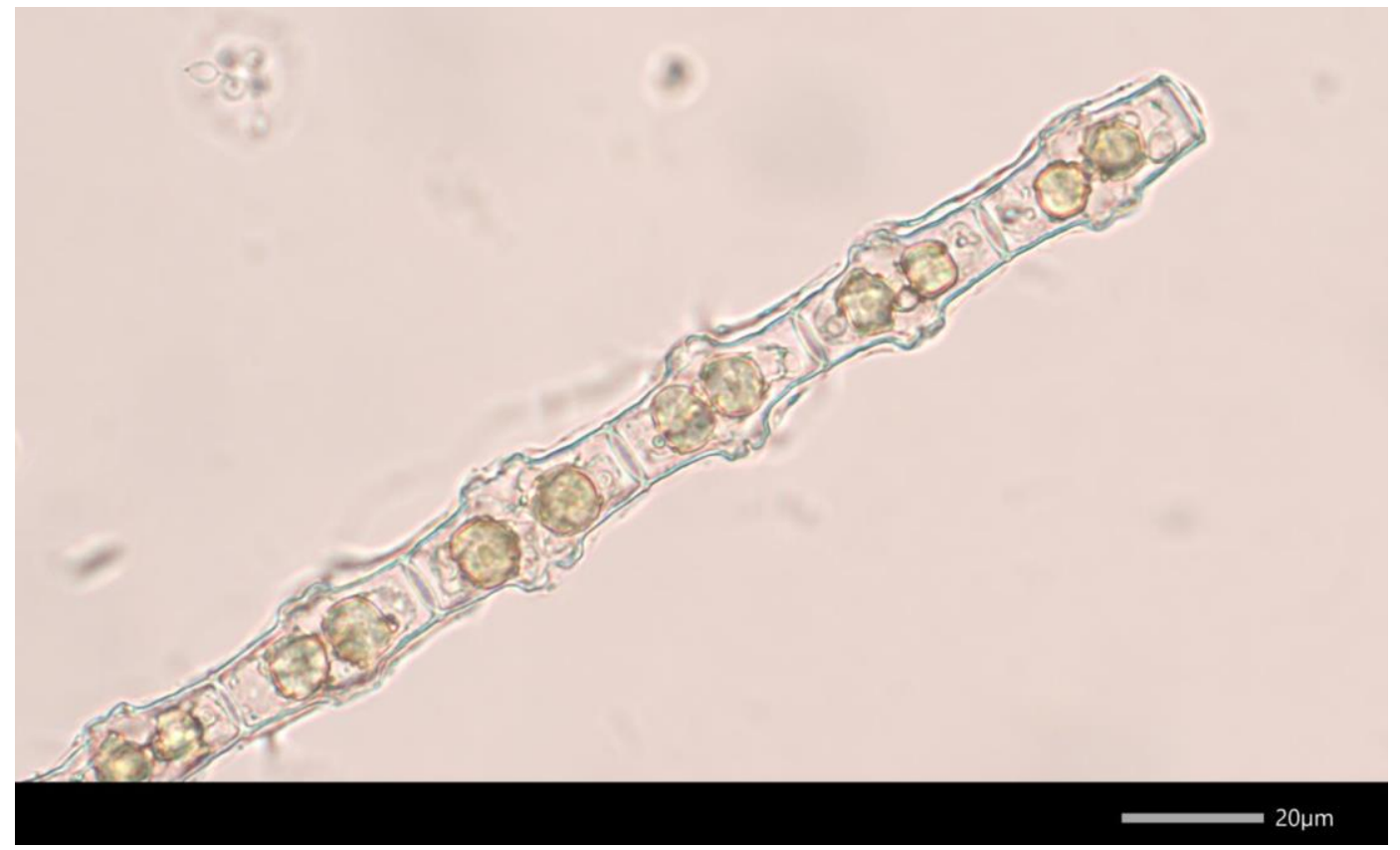


Closterium cf. angustatum Kützing ex Ralfs, 1848

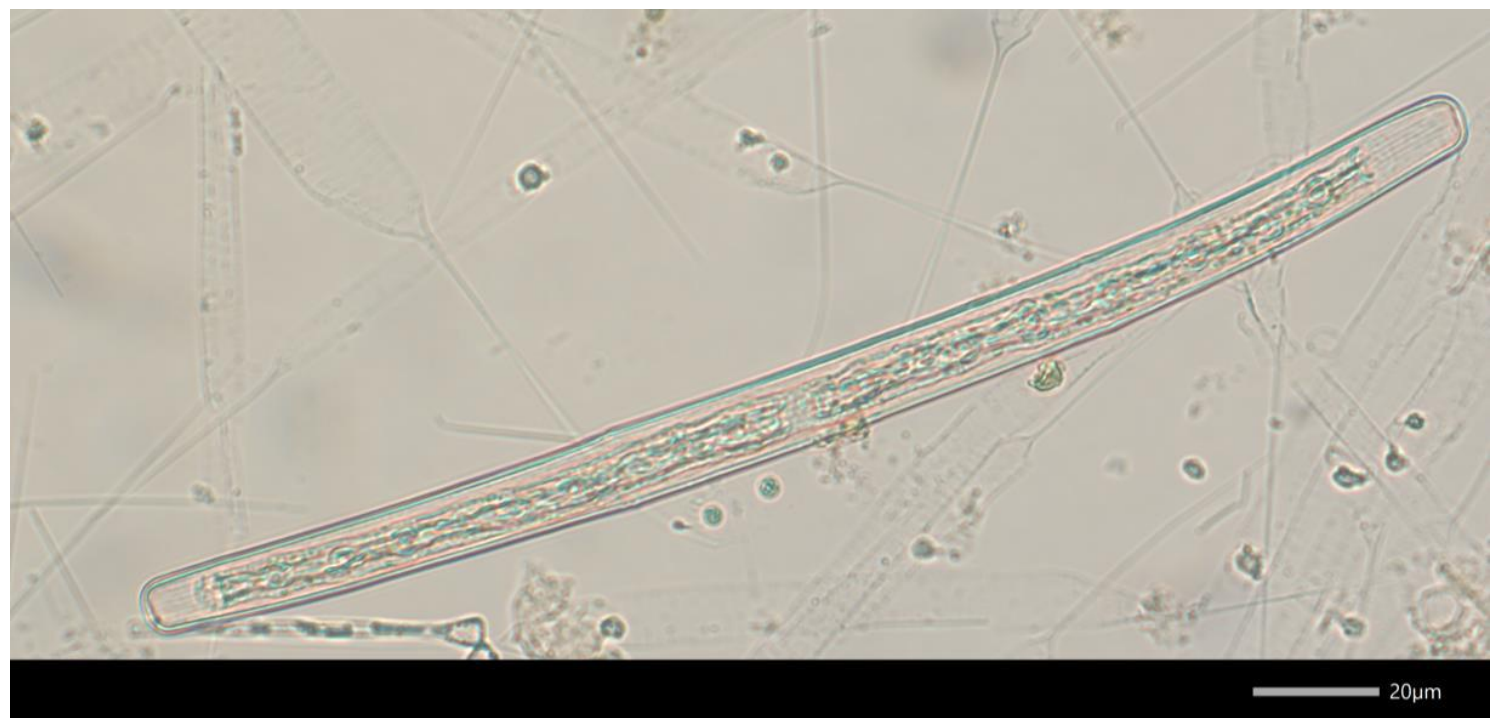

Closterium dianae Ehrenberg ex Ralfs, 1848

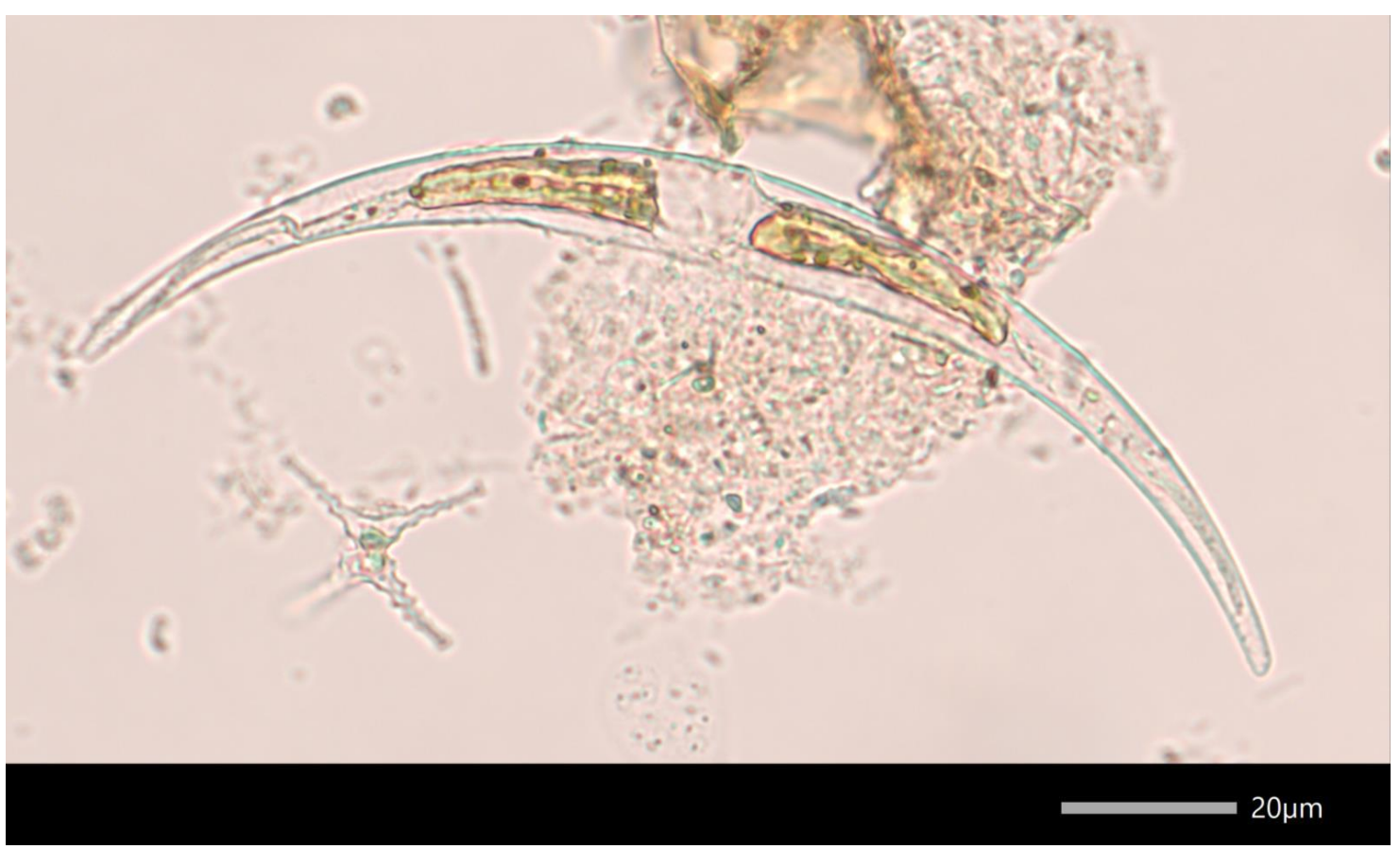


Closterium cf. gracile Brébisson et Ralfs, 1848

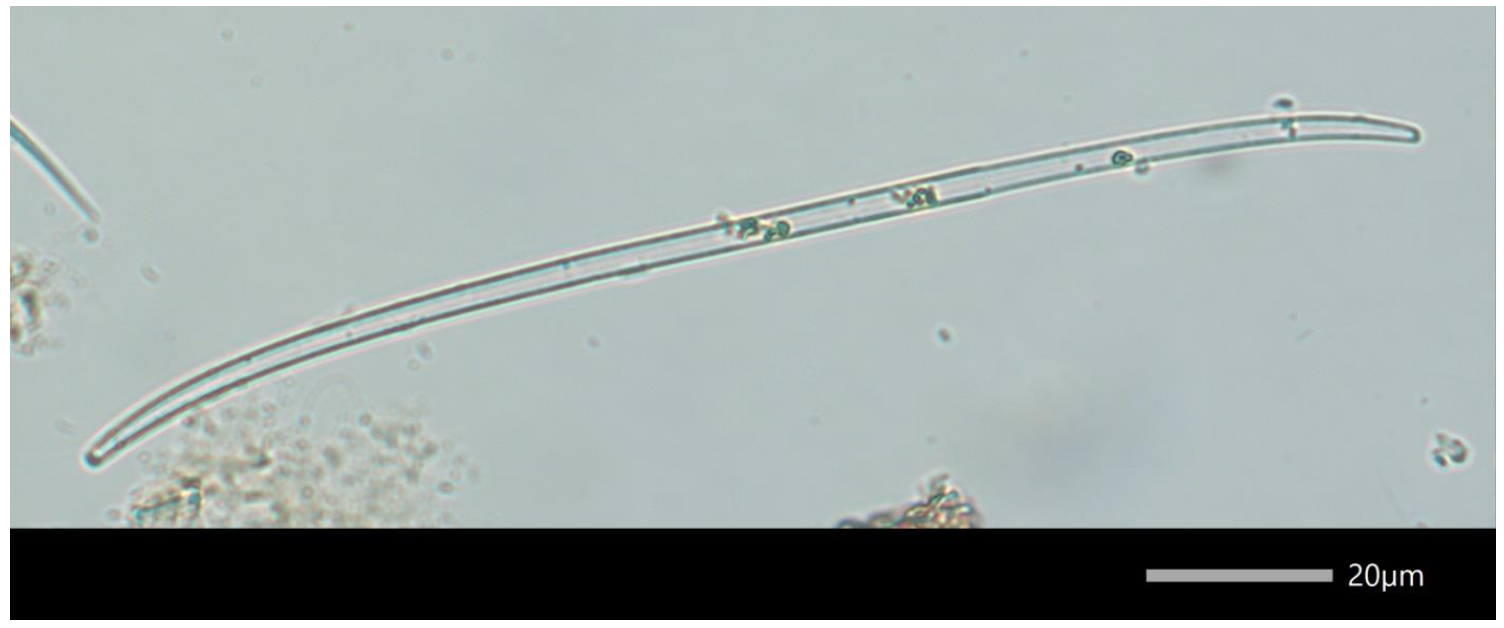

Closterium setaceum Ehrenberg ex Ralfs, 1848

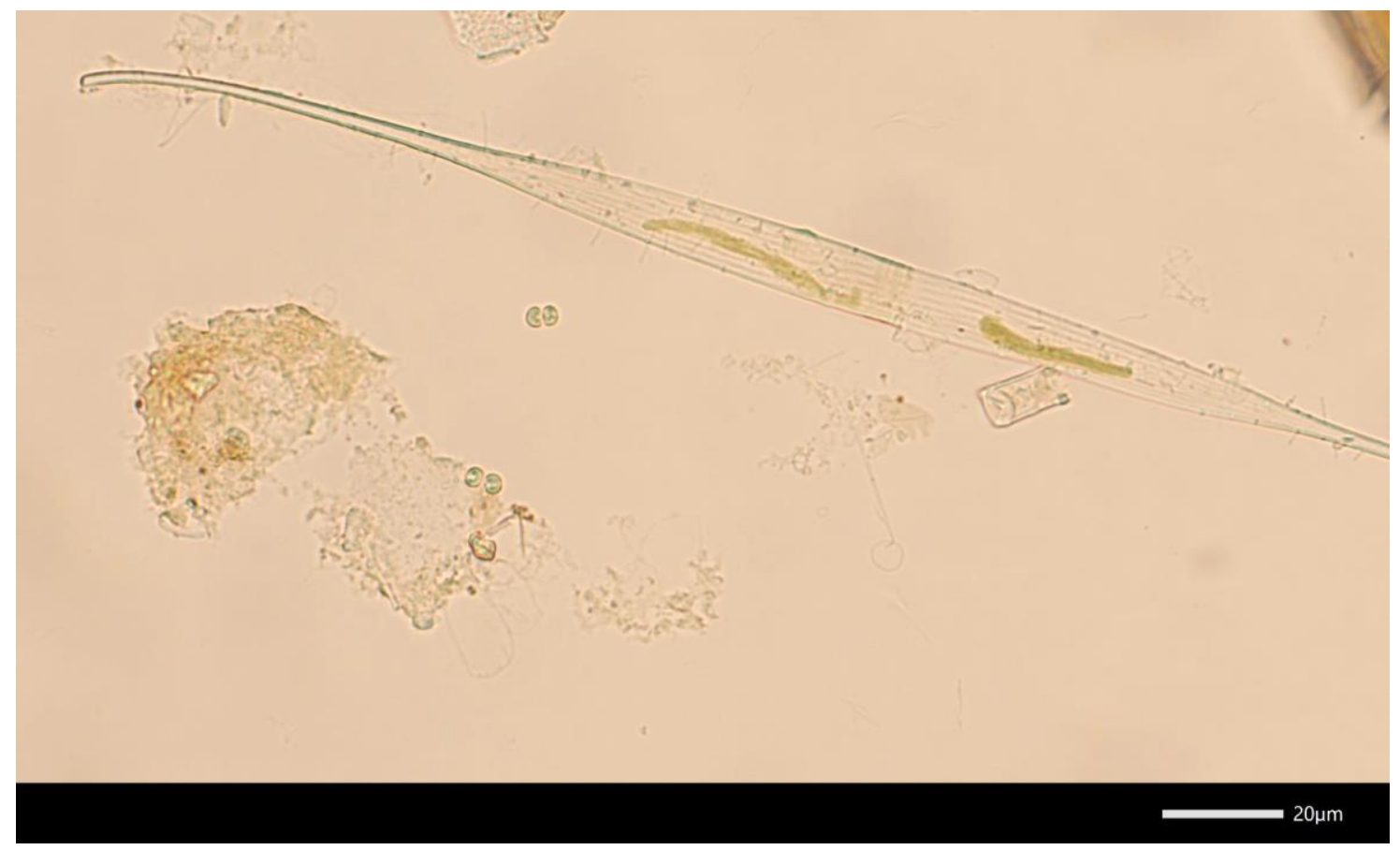


Closterium setaceum v. elongatum West \& G.S. West, 1905

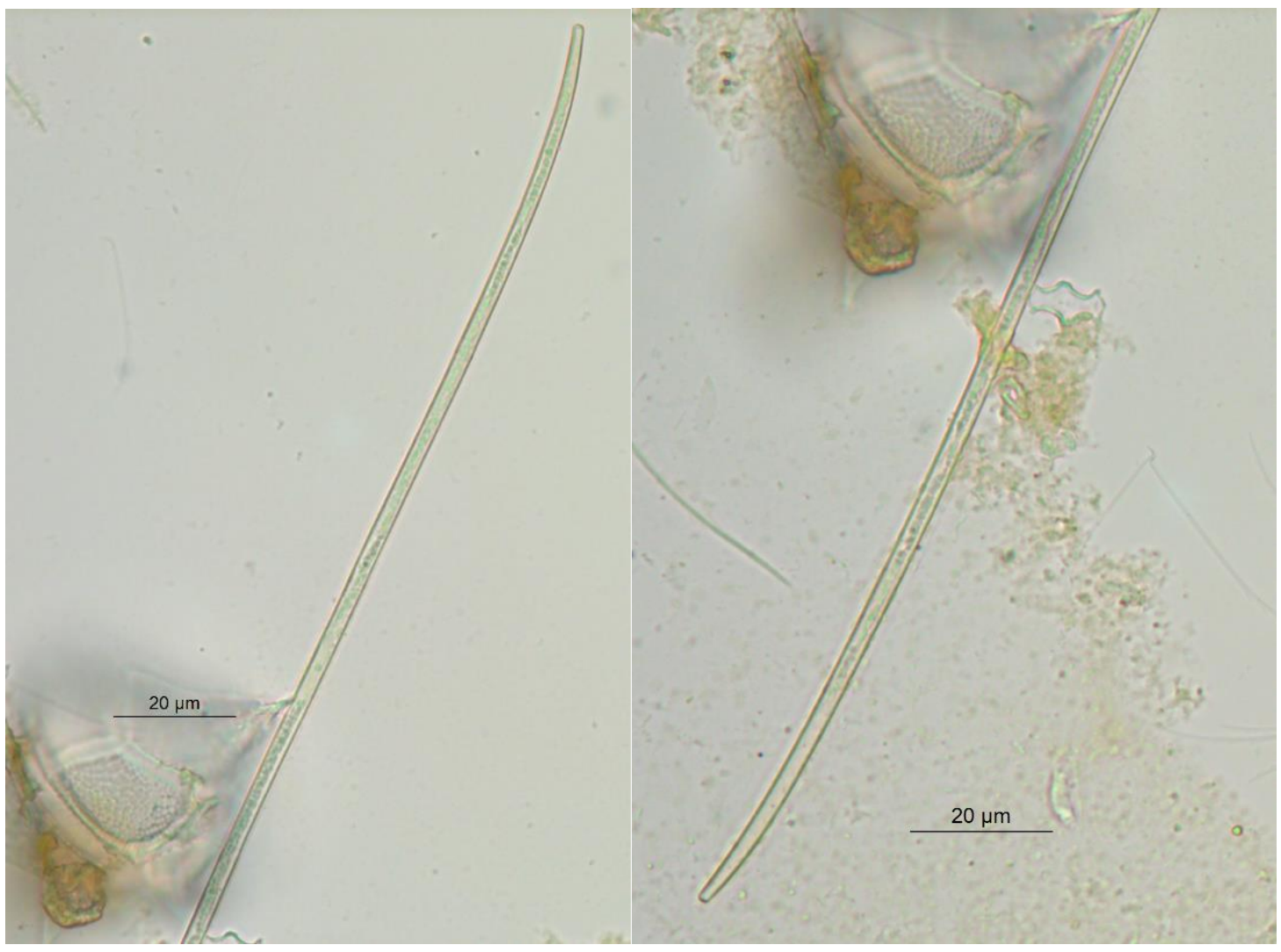

Closterium setaceum v. vittatum Grönblad, 1945

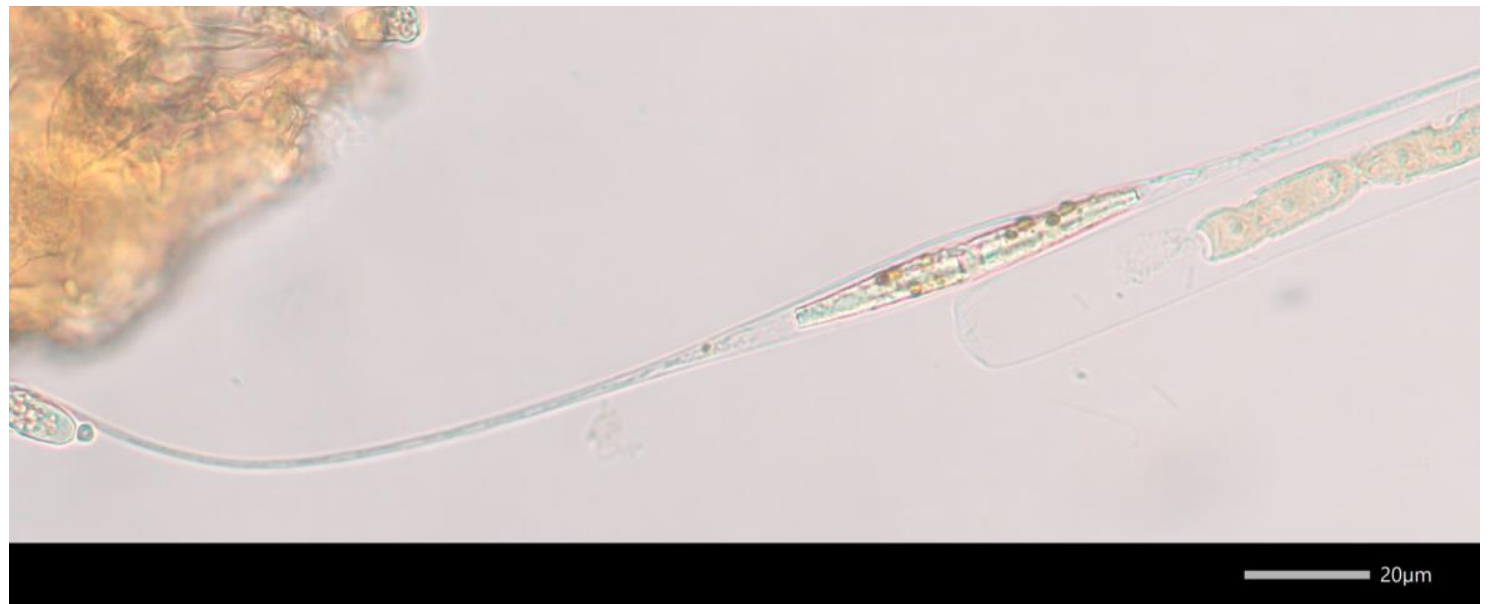


Cosmarium contractum v. ornatum Kurt Förster, N.D.

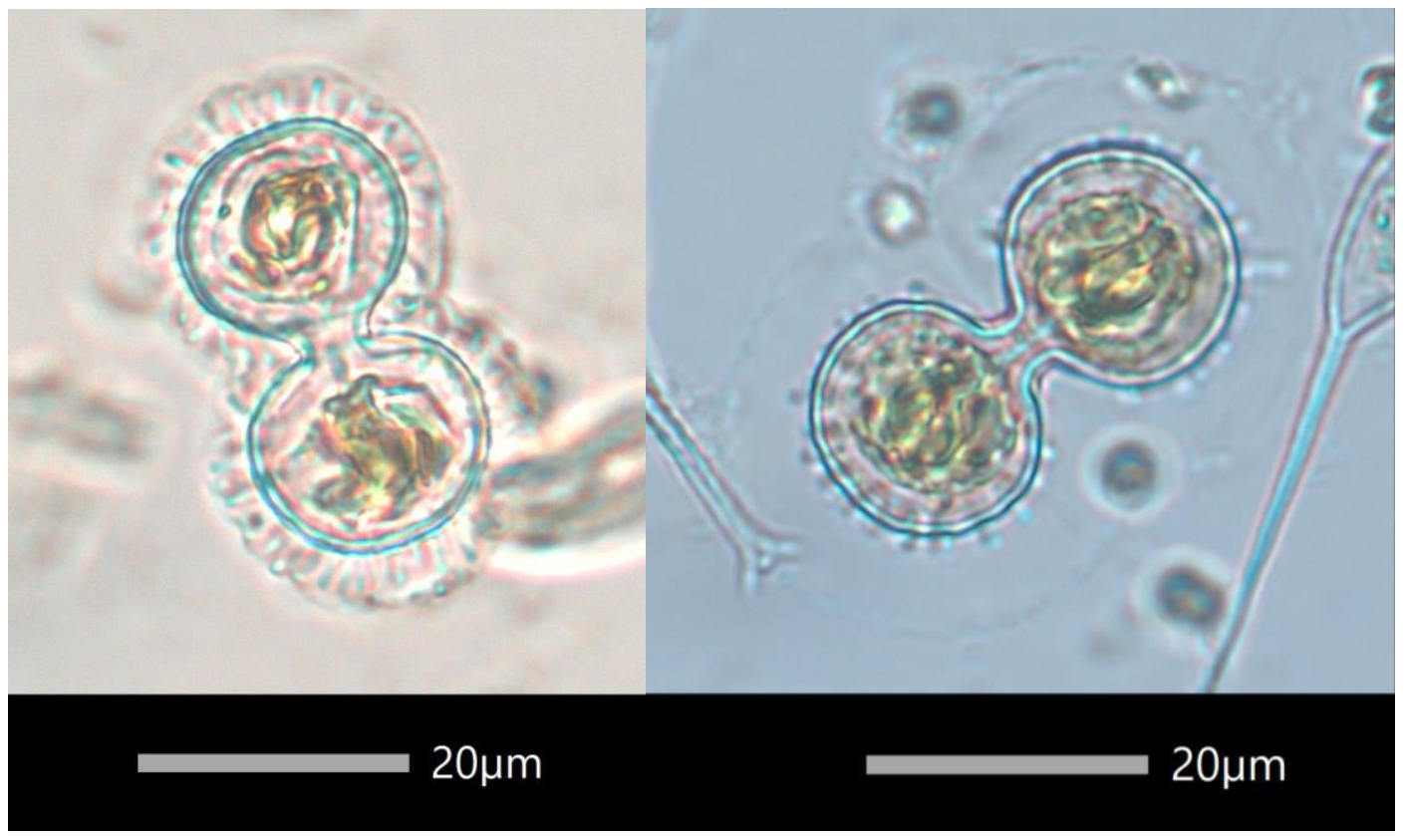

Cosmarium margaritatum f. minus (Boldt) West \& G.S. West, 1897

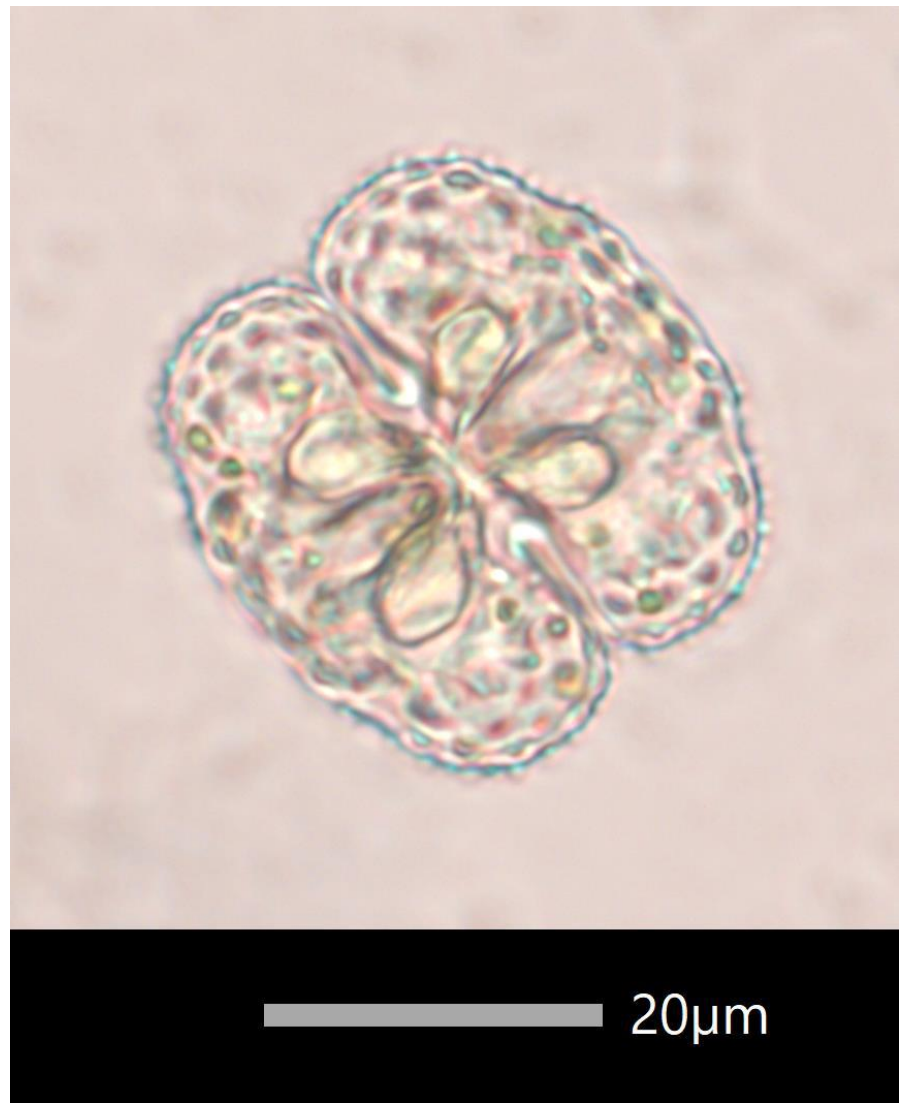


Cosmarium ocellatum v. incrassatum West \& G.S. West, 1897

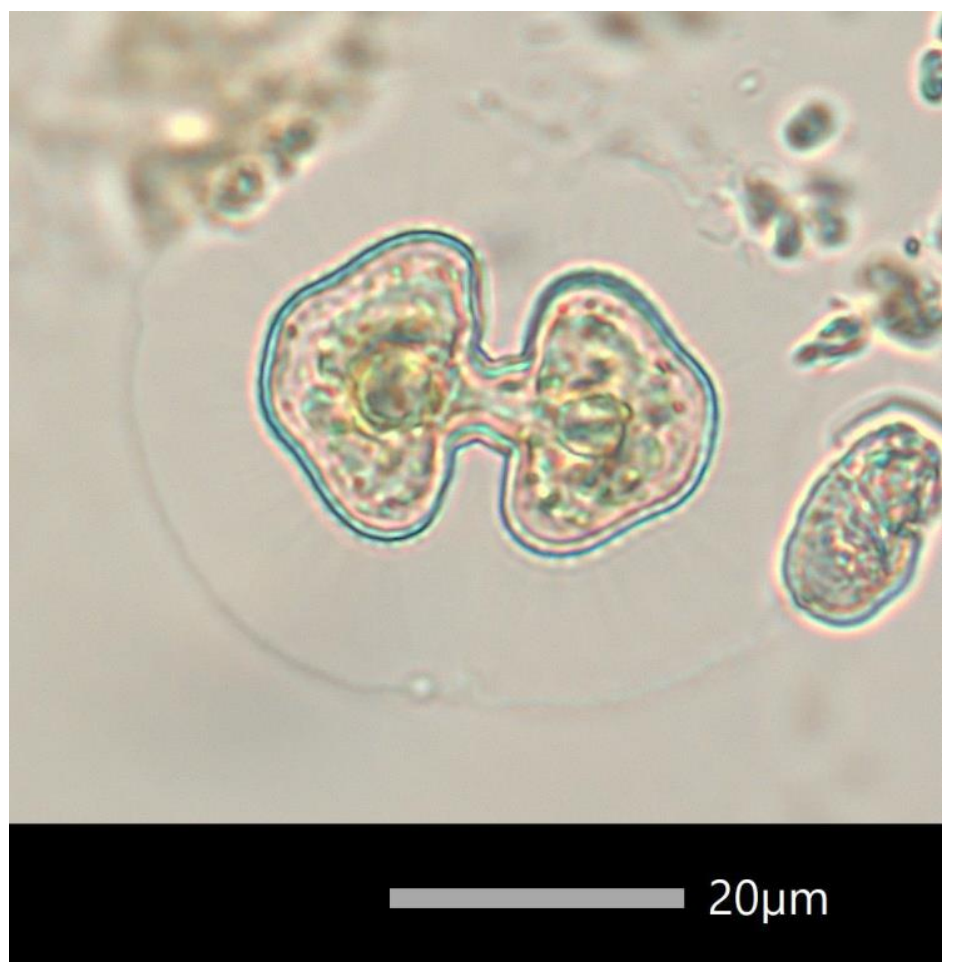

Cosmarium panamense Prescott, 1936

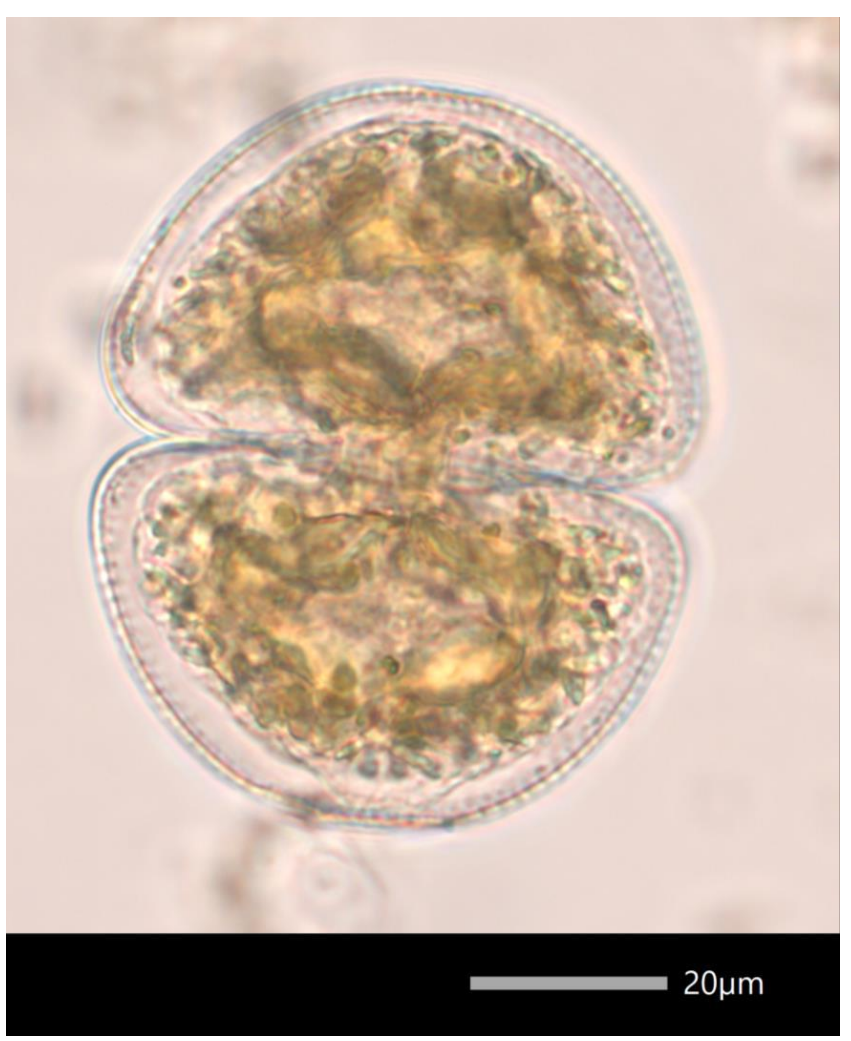


Cosmarium cf. pseudotaxichondrum v. scottii Kurt Förster, 1974
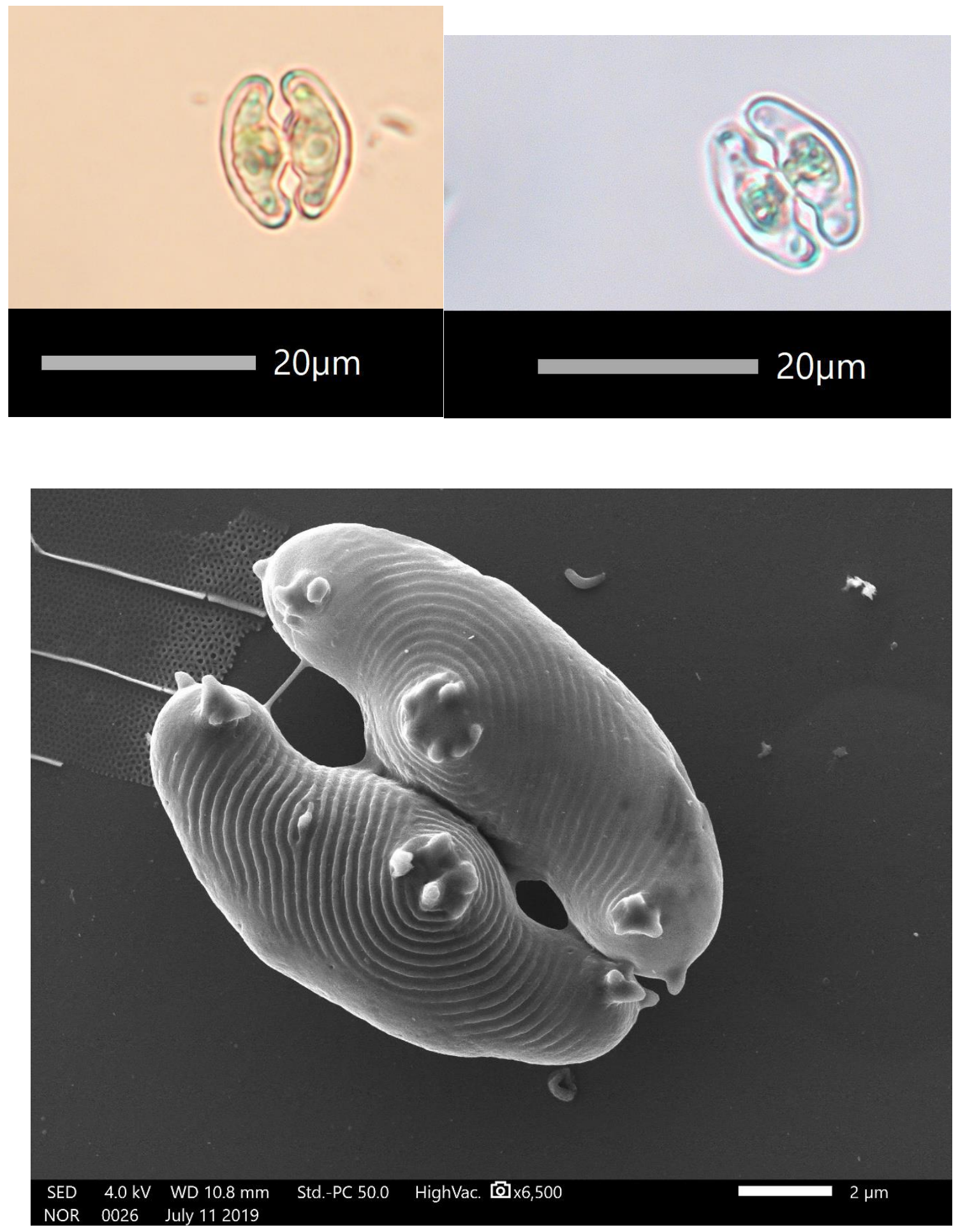
Desmidium aptogonum v. constrictum Brébisson ex Kützing, 1849

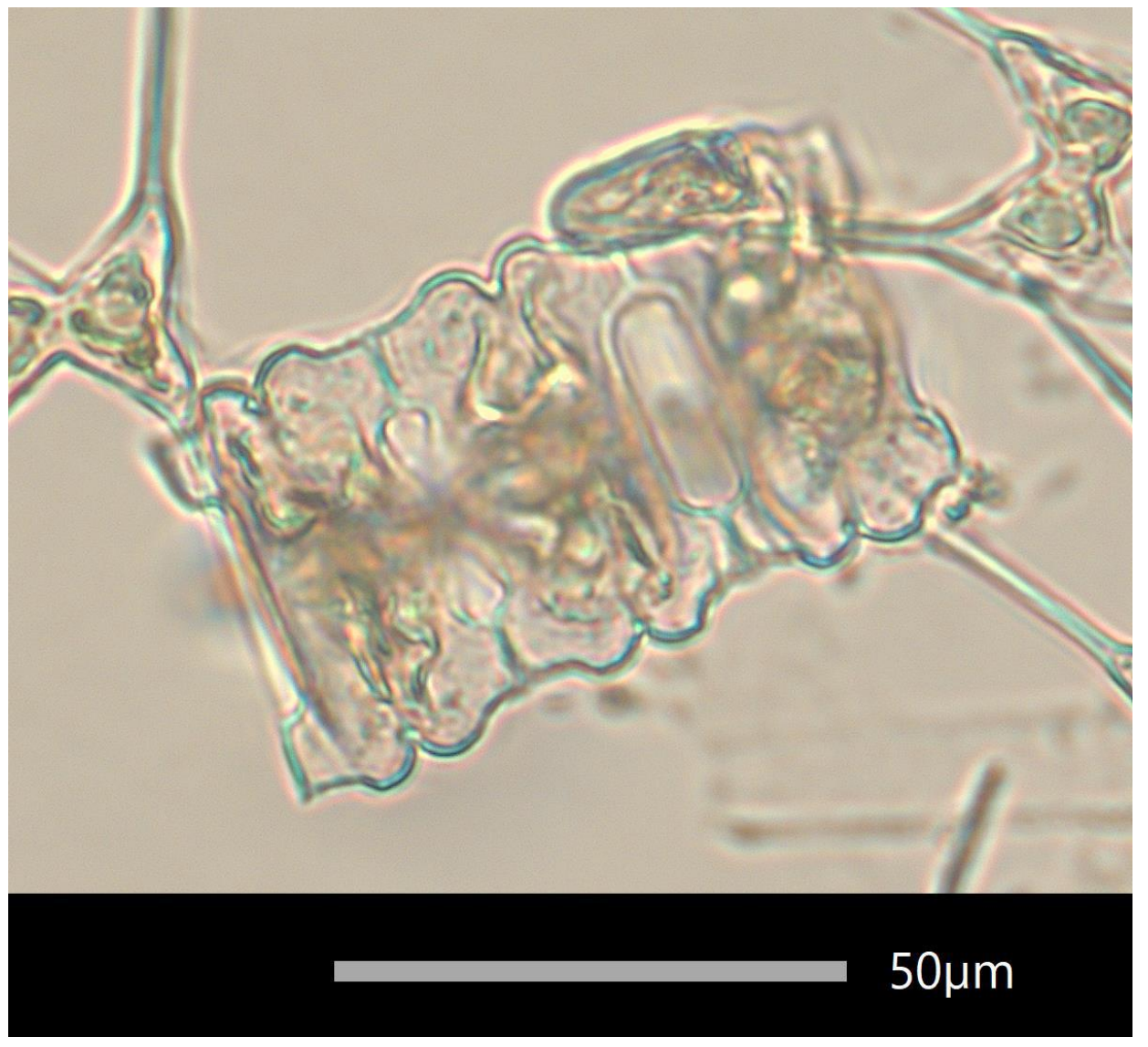


Desmidium baileyi v. subcirculare A.M. Scott \& Grönblad, N.D.
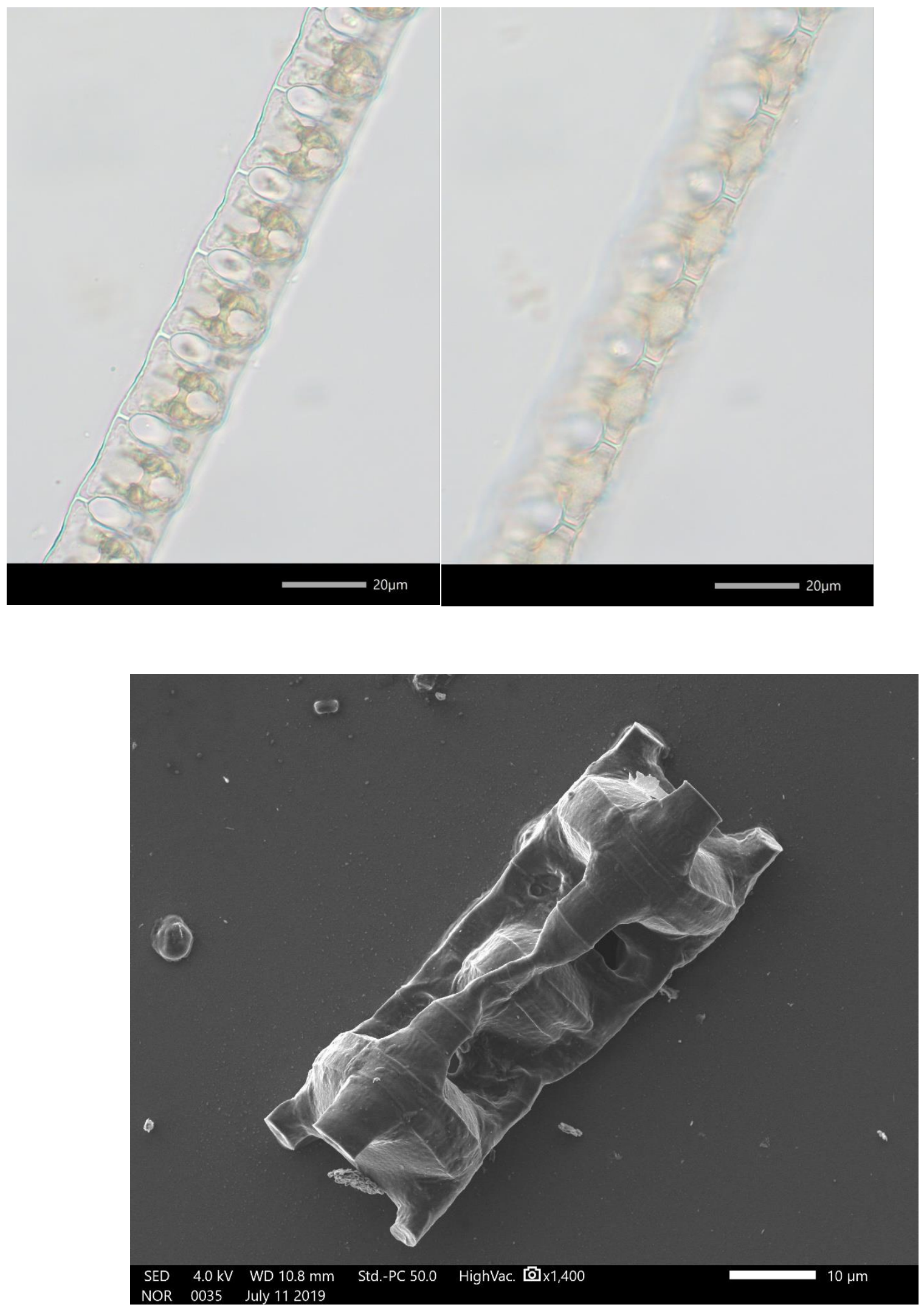
Desmidium quadrangulatum Ralfs ex Ralfs, 1848

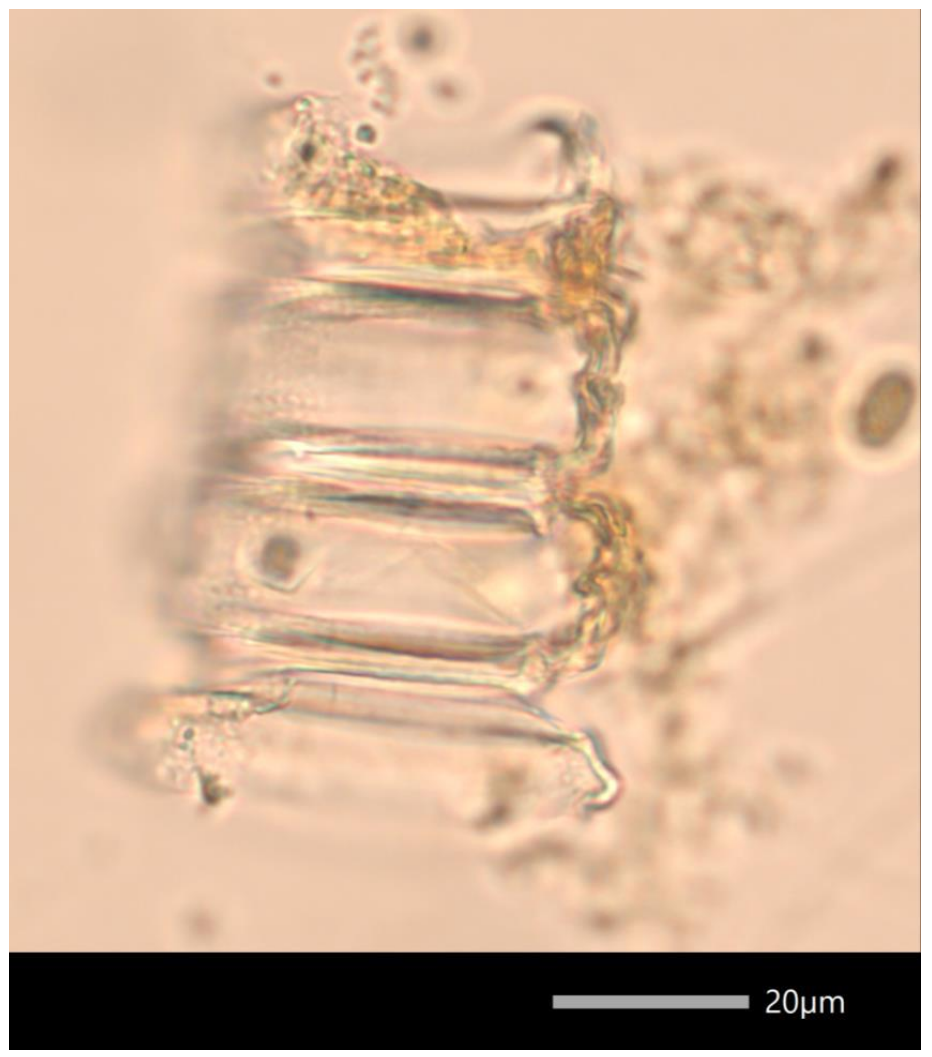

Desmidium swartzii C. Agardh ex Ralfs, 1848

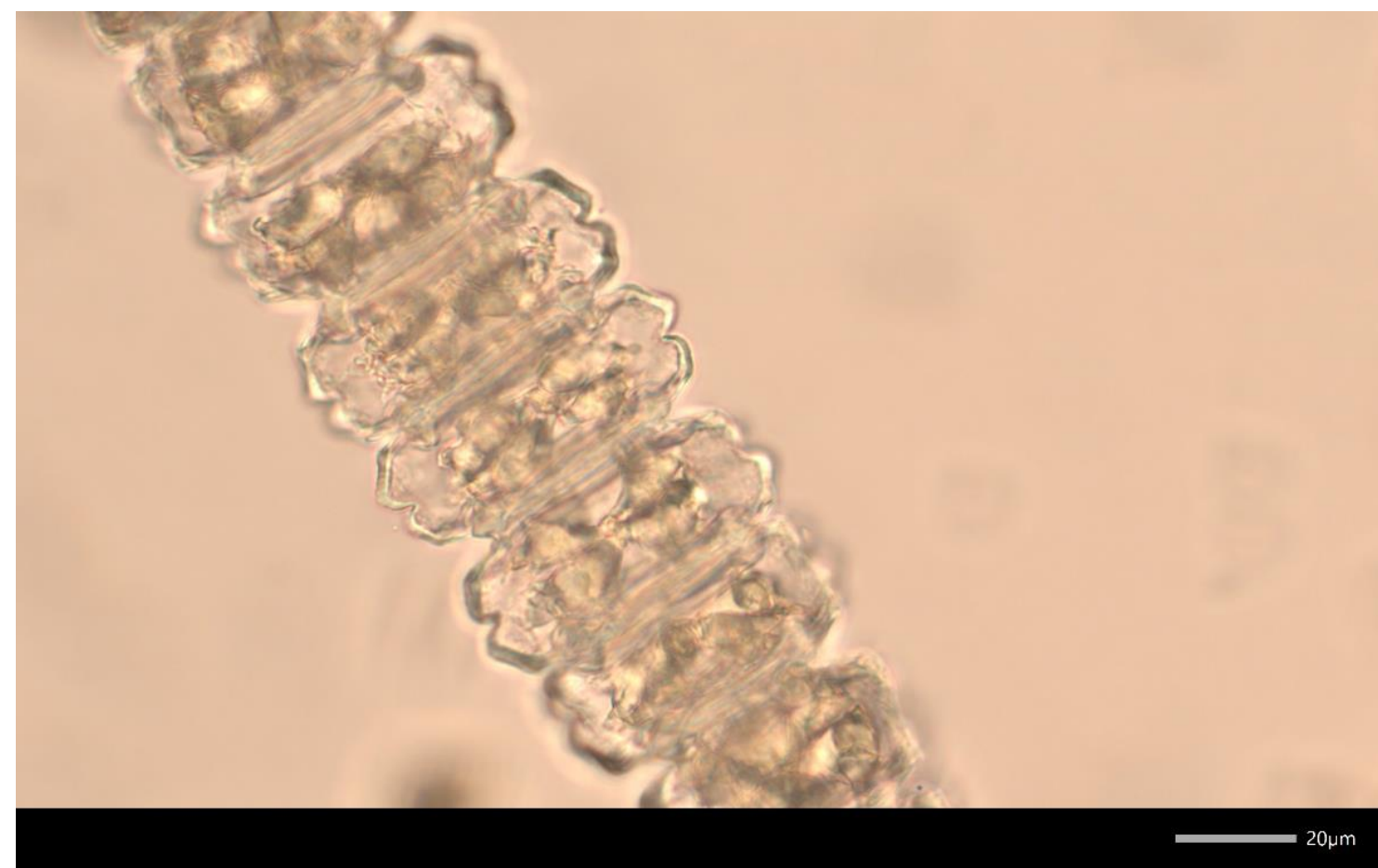


Docidium cf. baculum Brébisson ex Ralfs, 1848

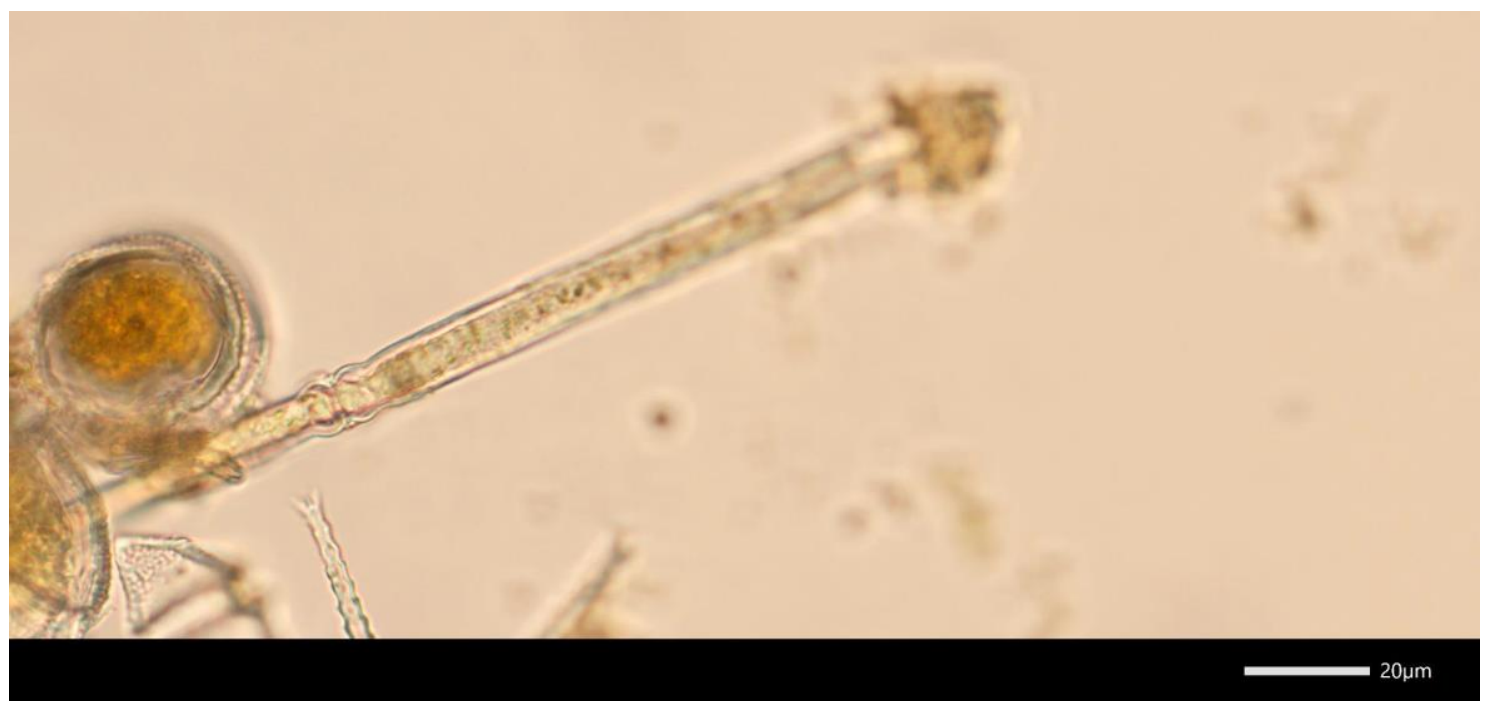

Docidium pleurotaenoides A.M. Scott \& Croasdale, 1975

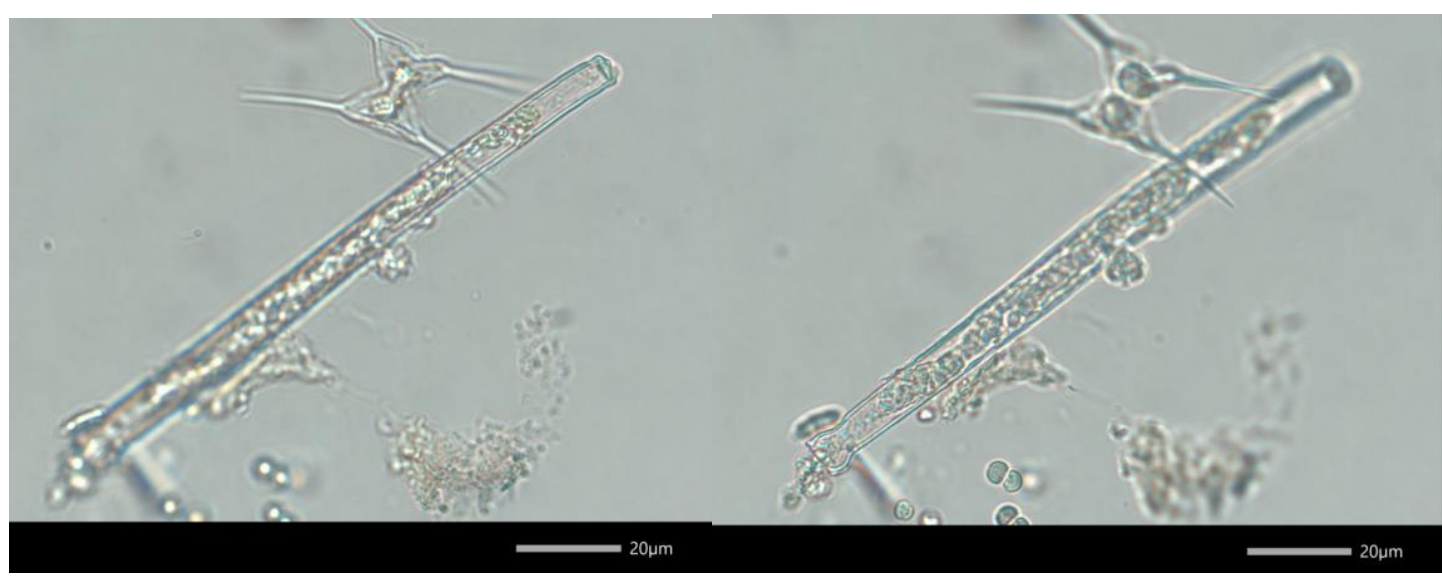


Elakatothrix gelatinosa Wille, 1898

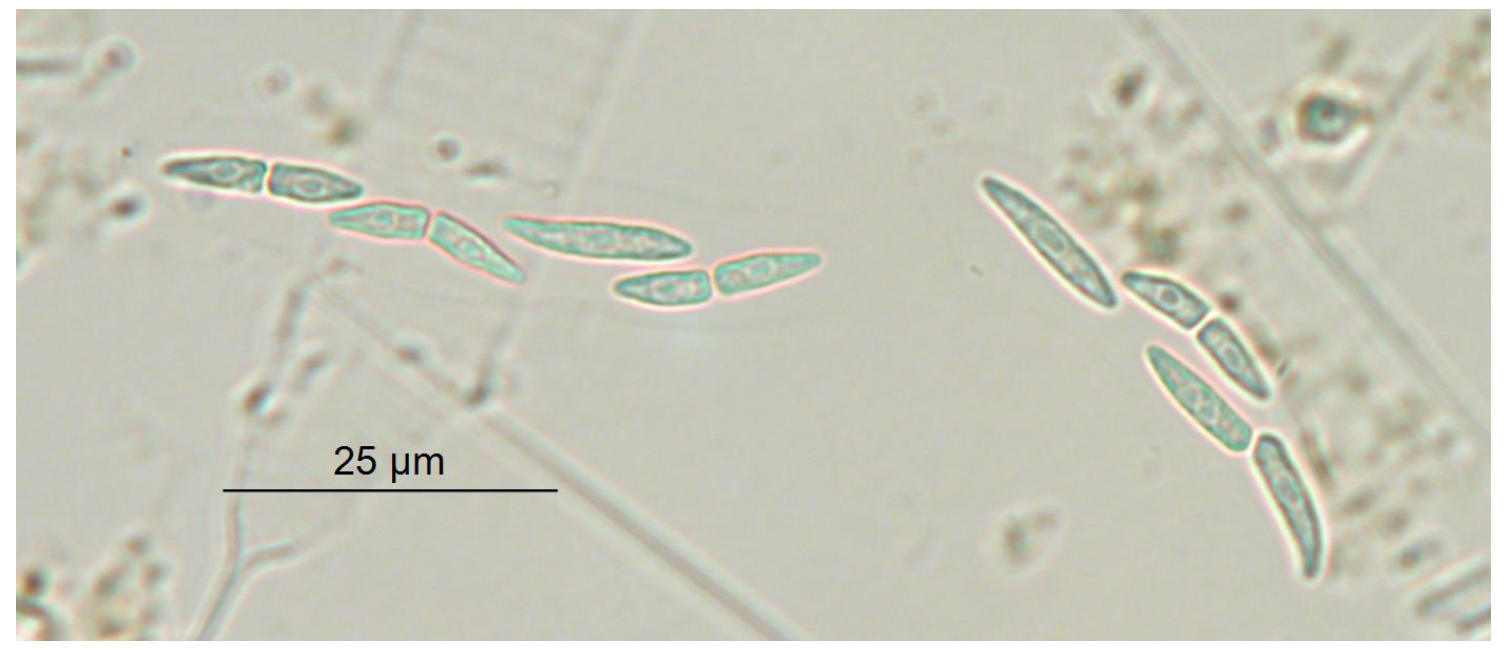

Euastrum informe O.F. Borge, 1925

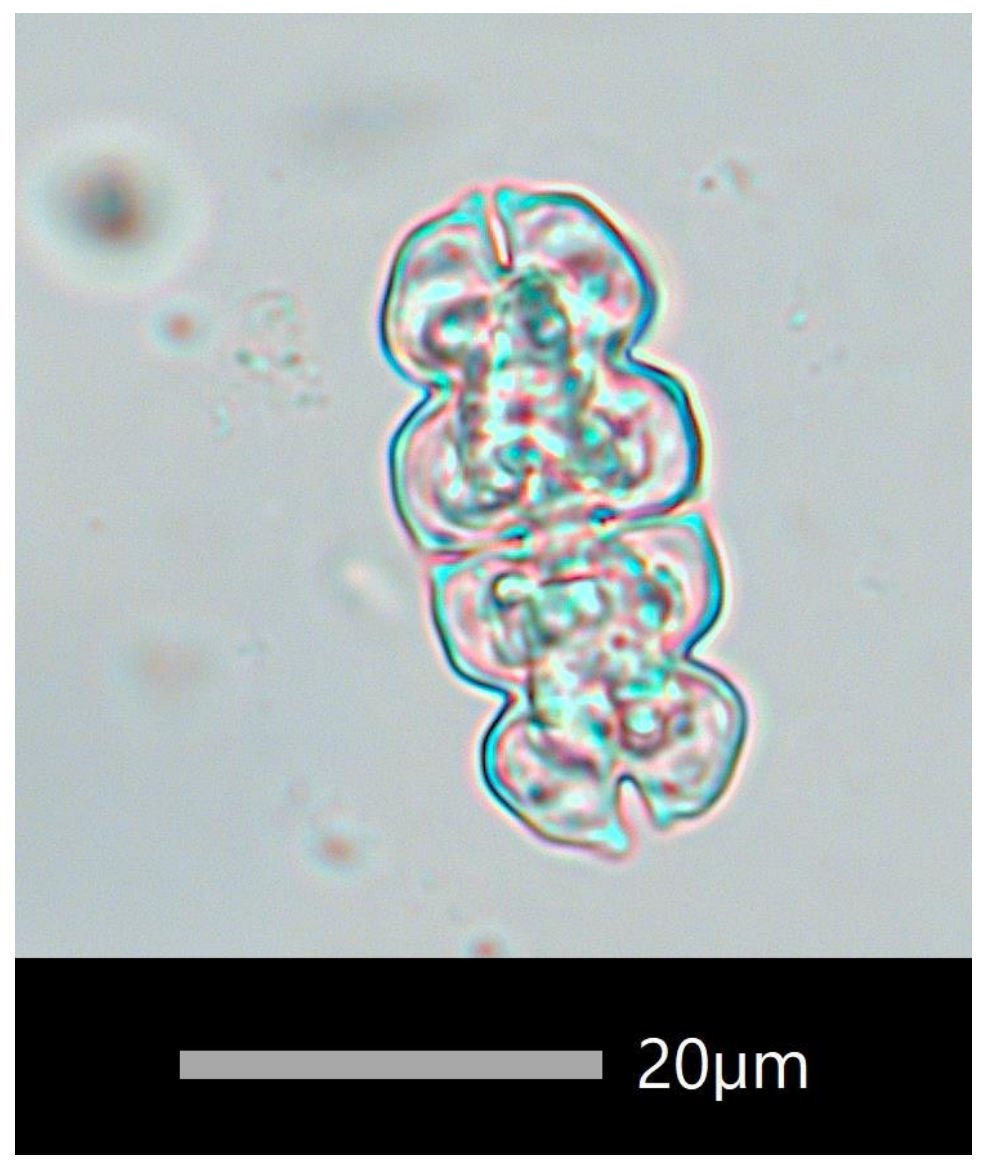


Euastrum intermedium Cleve, 1864

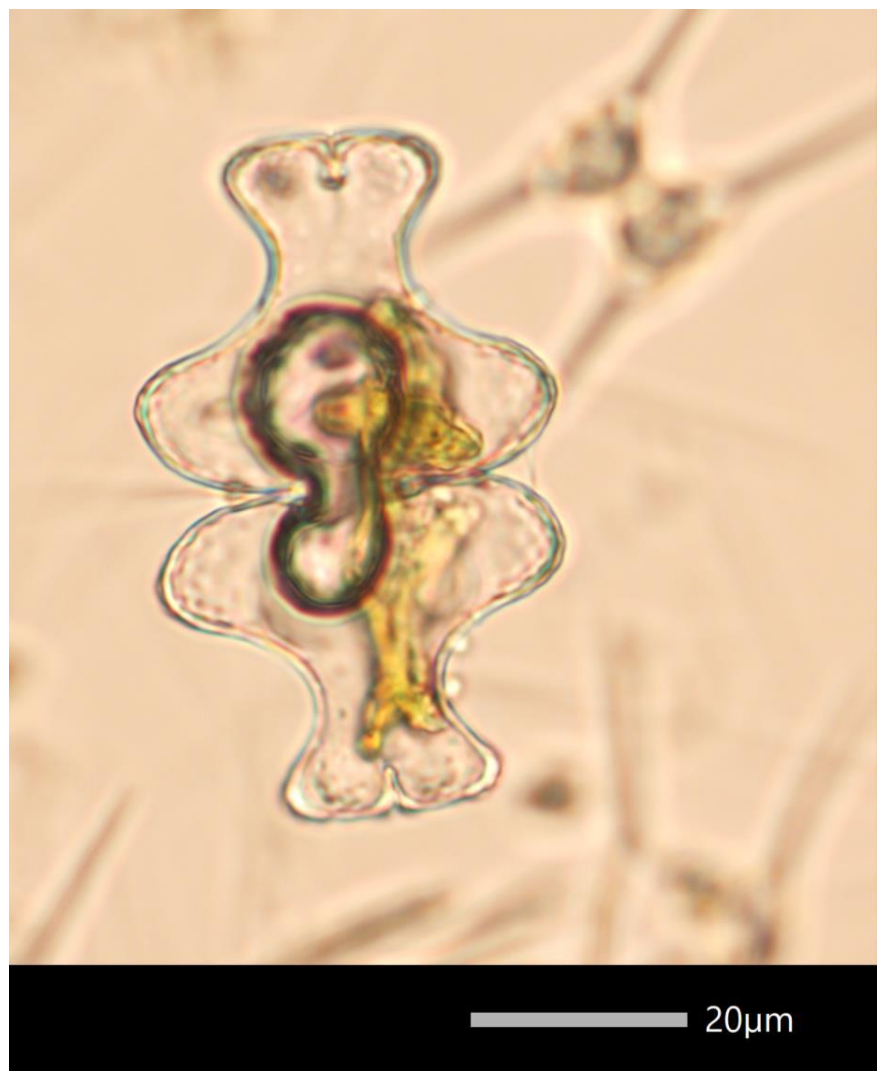

Euastrum ventricosum v. rectangulare Prescott \& A.M. Scott, 1945

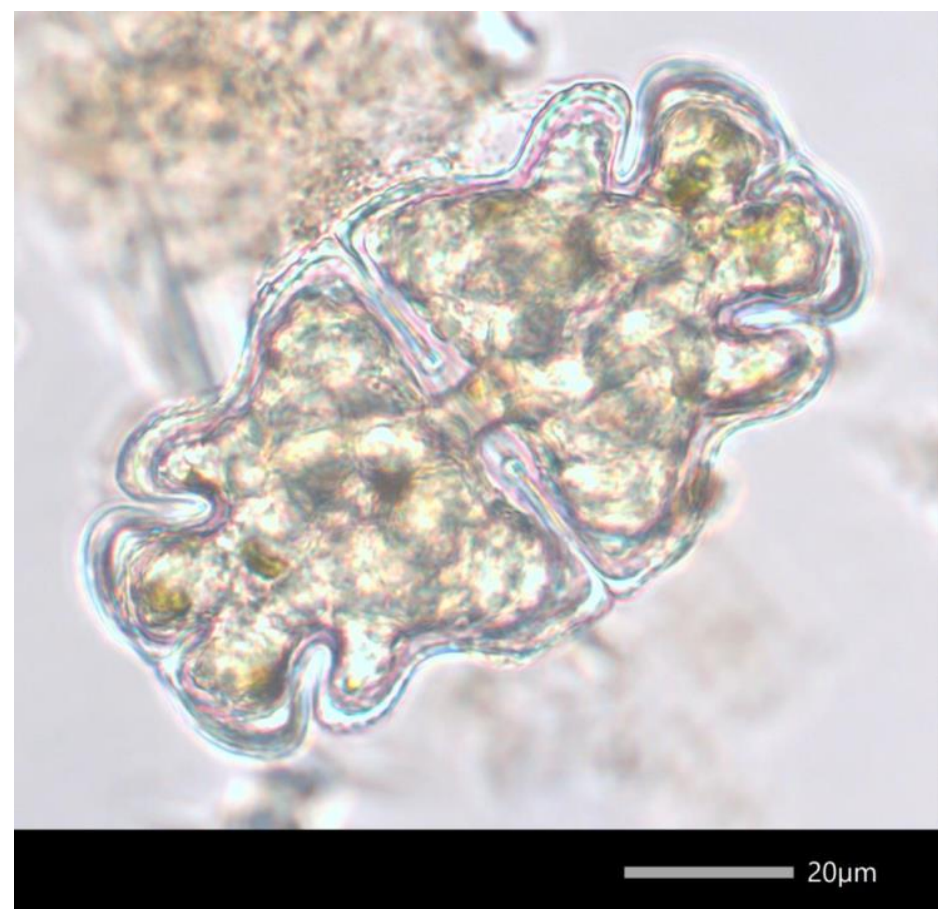


Euastrum wollei v. pearlingtonense Prescott \& A.M. Scott, N.D.

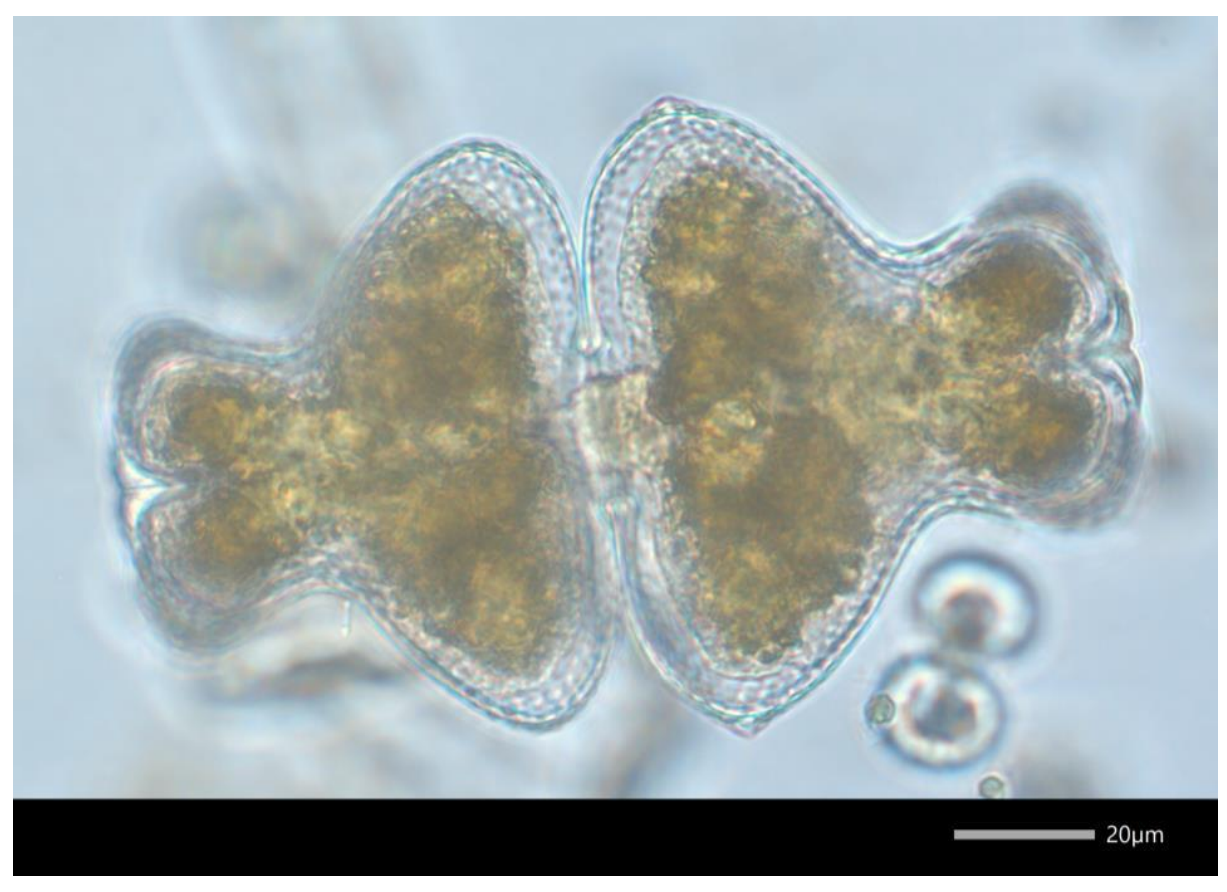

Gonatozygon cf. aculeatum W.N. Hastings, 1892

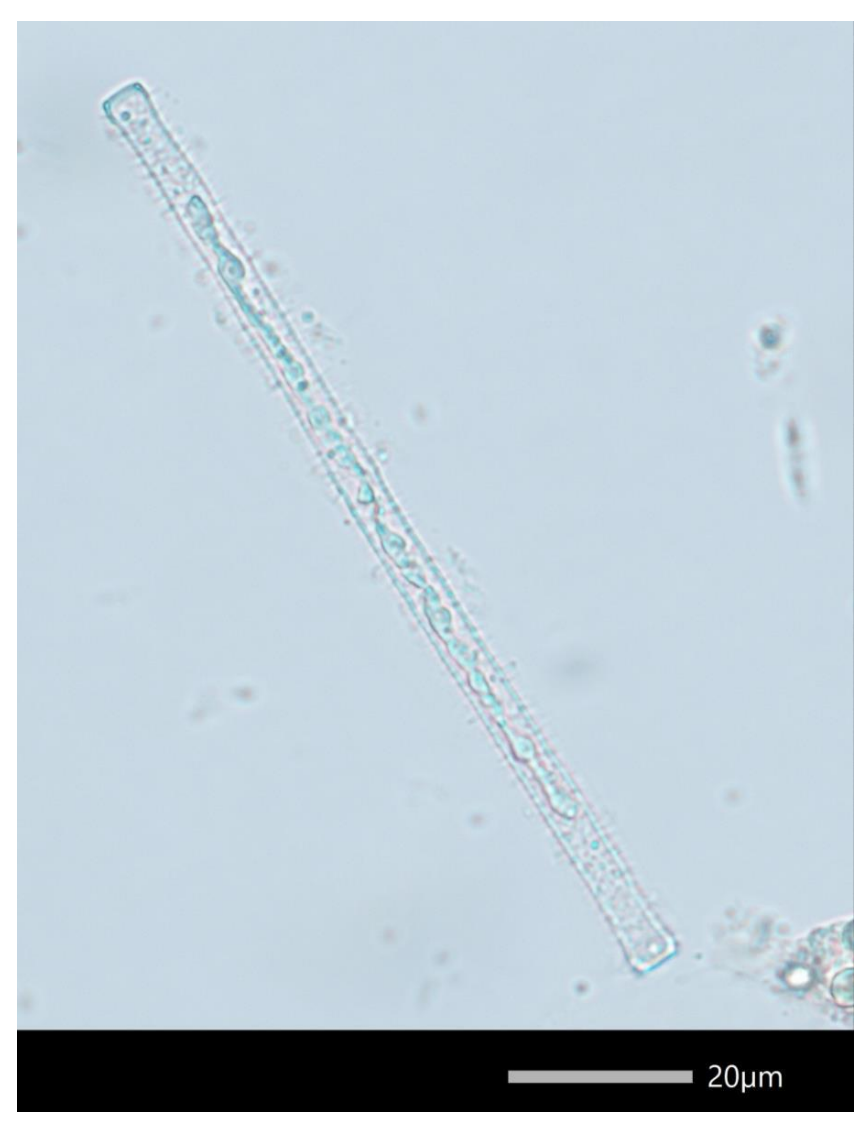


Groenbladia neglecta Teiling, 1952

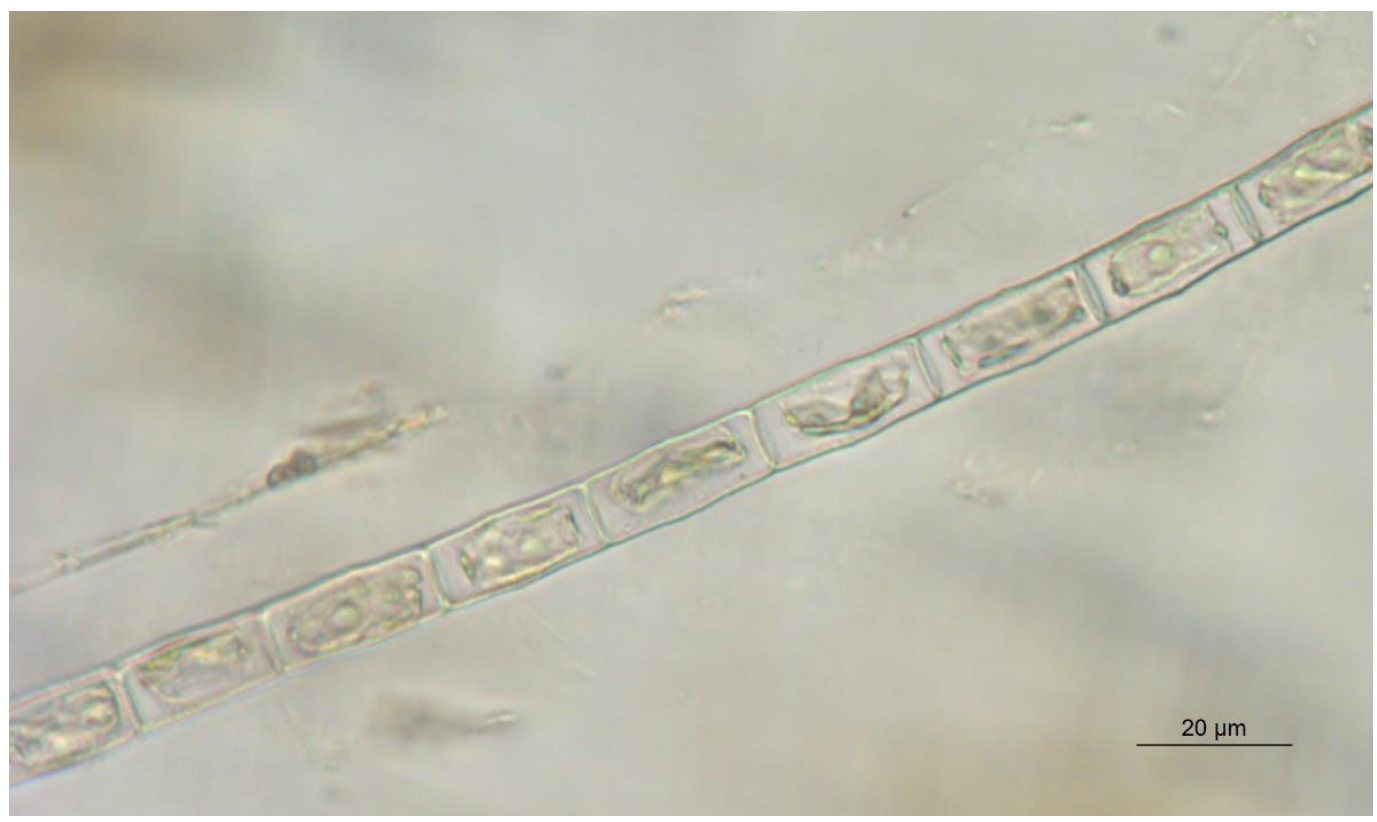

Groenbladia taylorii Scott \& Grönblad, 1957

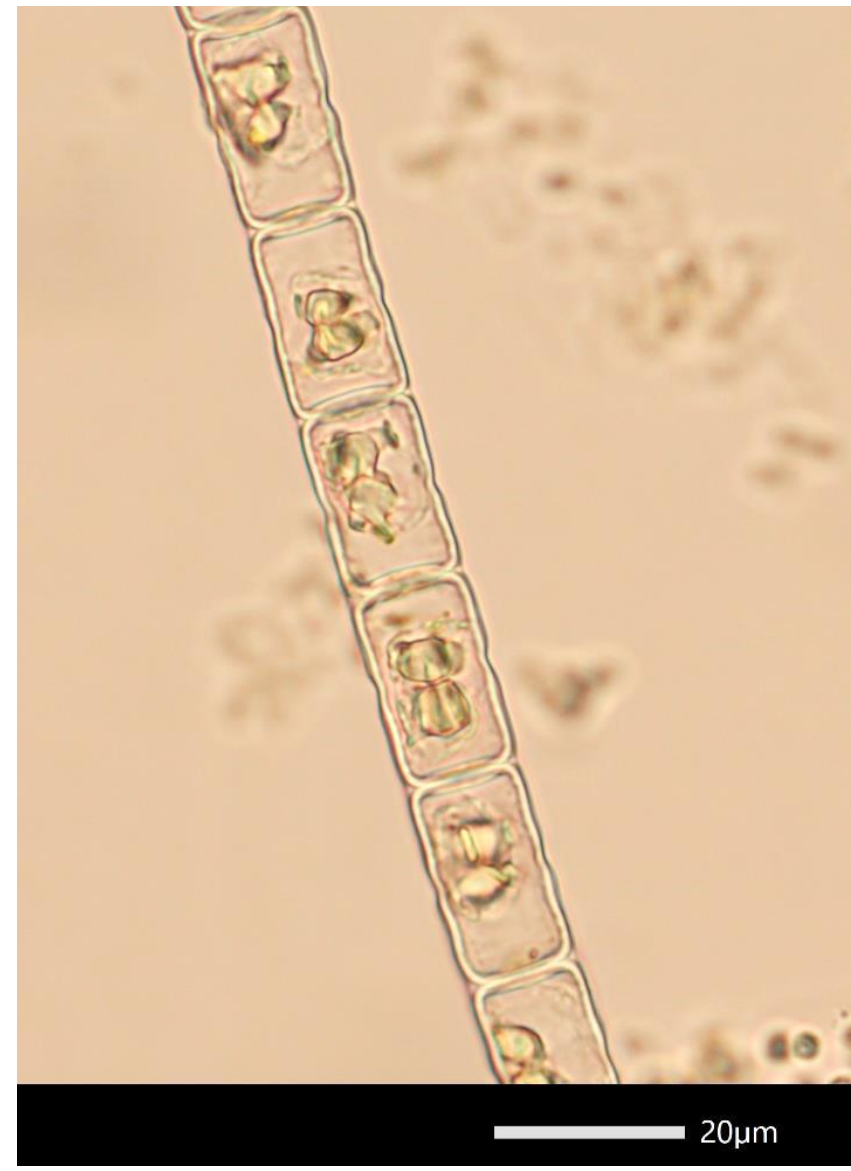


Groenbladia undulata (Nordstedt) Kurt Förster, 1973

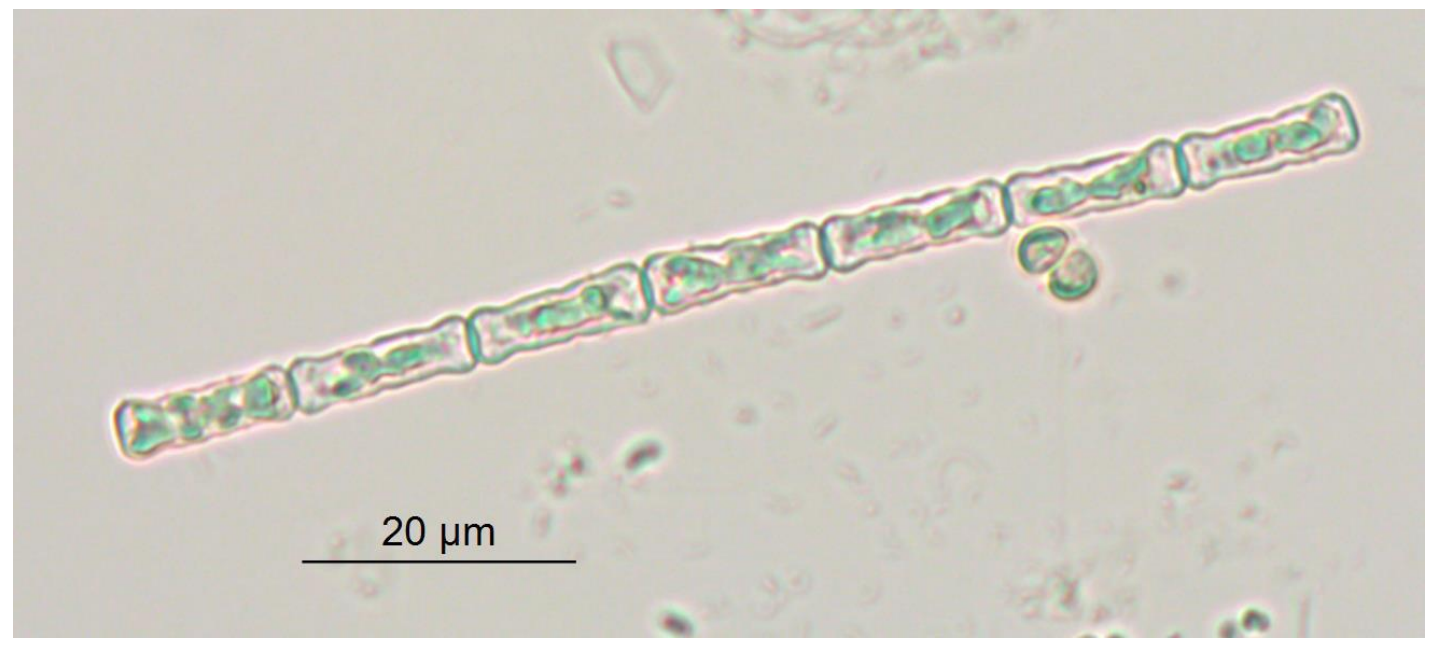

Hyalotheca dissiliens Brébisson ex Ralfs, 1848

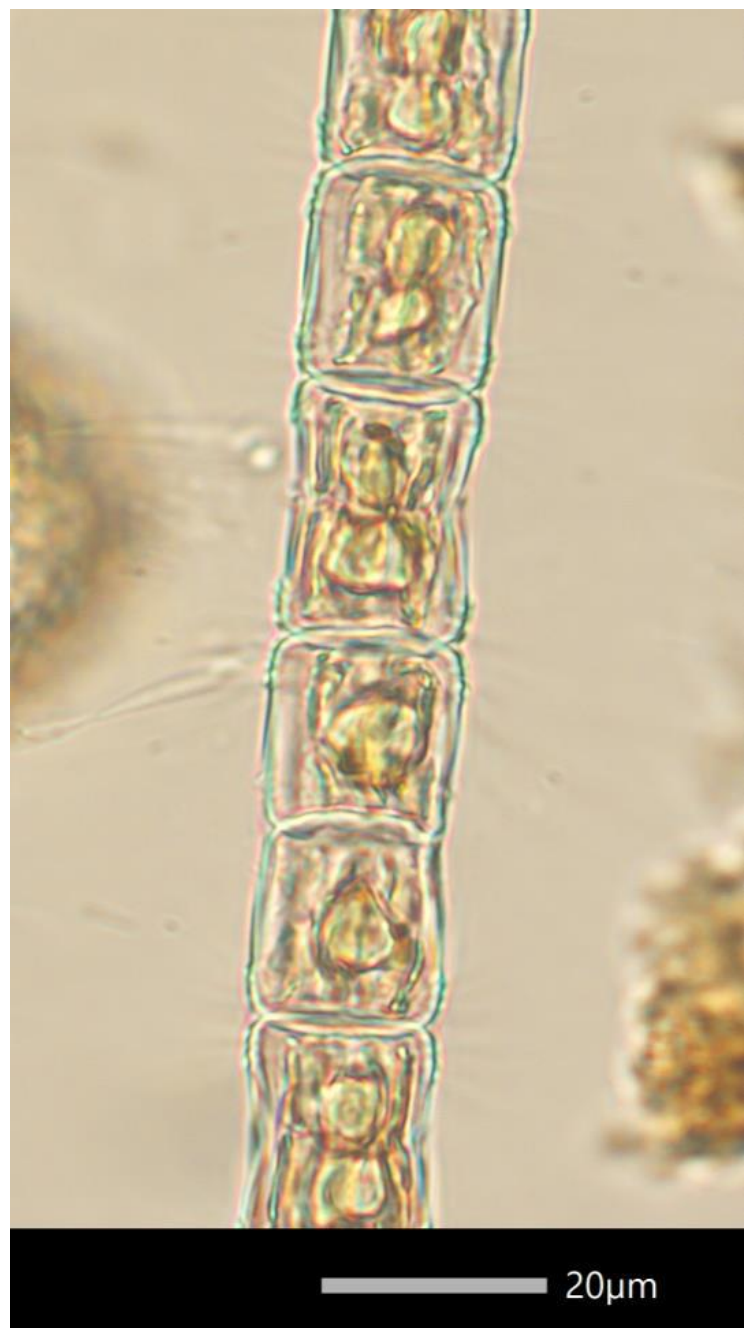


Micrasterias foliacea Bailey ex Ralfs, 1848

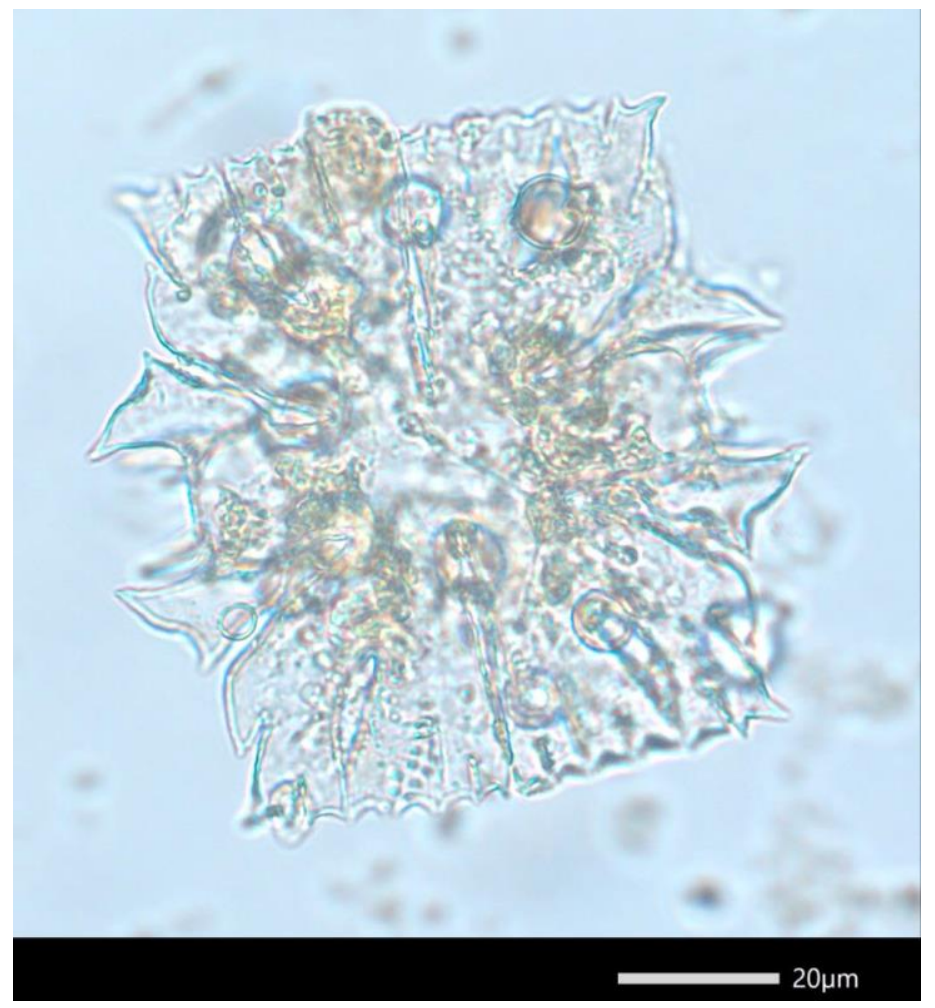

Micrasterias johnsonii West \& G.S. West, 1898

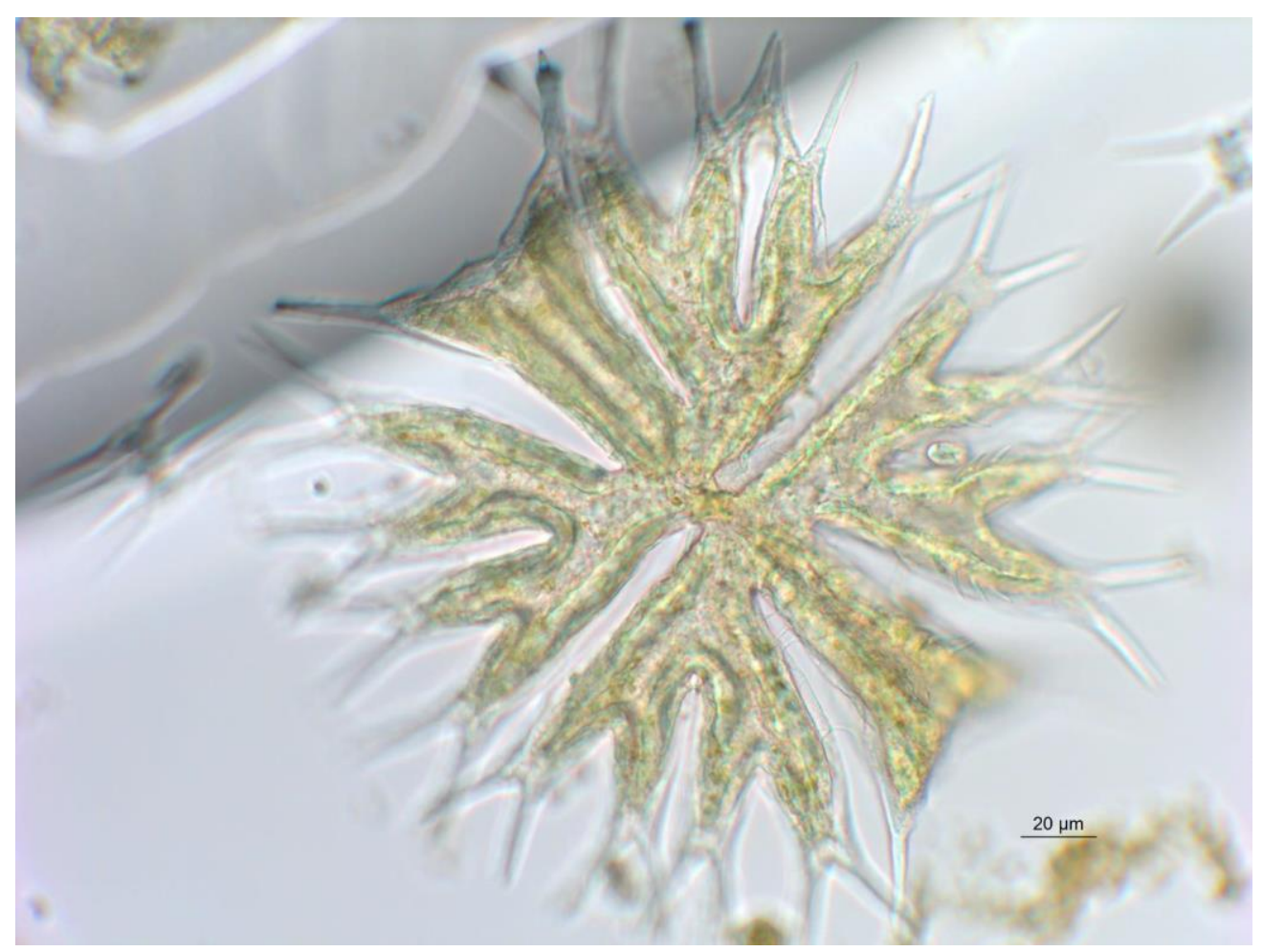


Micrasterias radiata f. parallela Prescott \& A.M. Scott, 1952

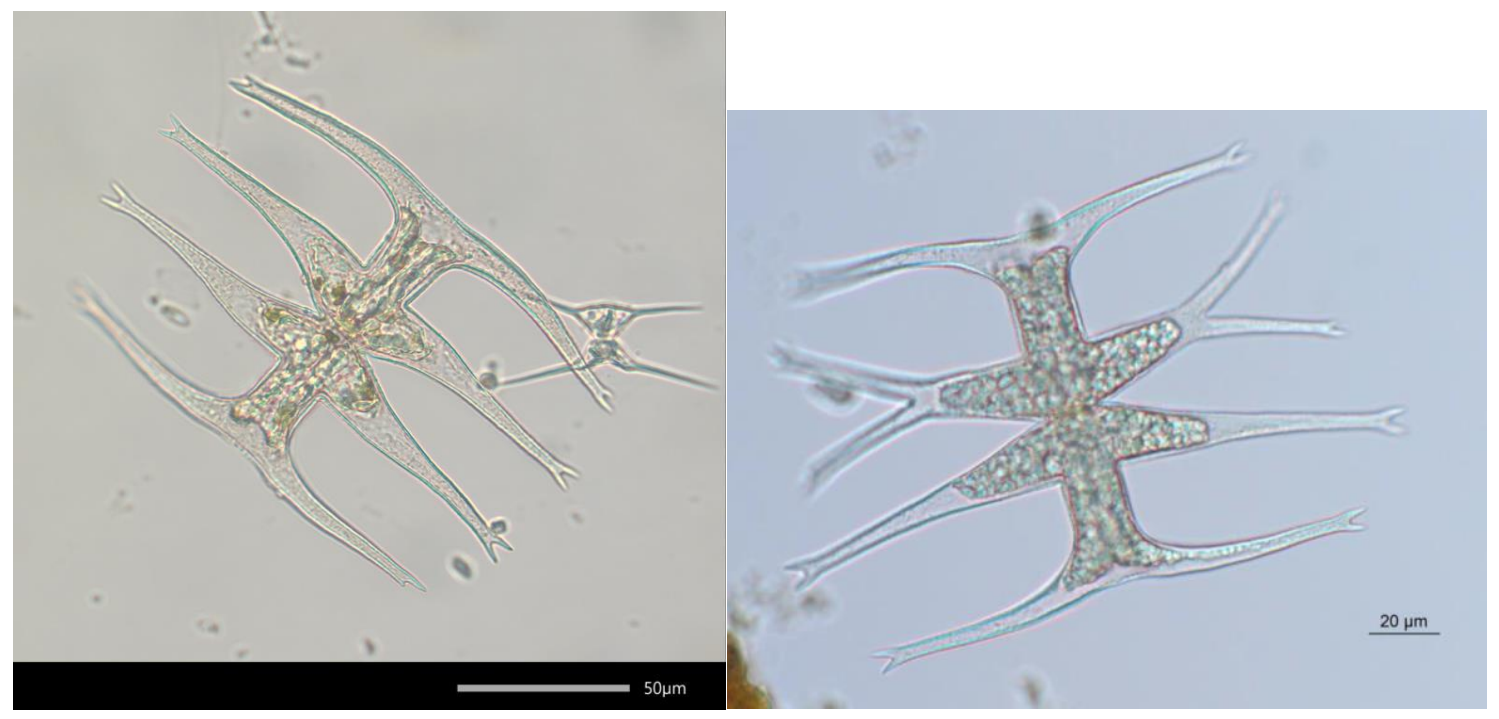

Mougeotia spp. C. Agardh, 1824

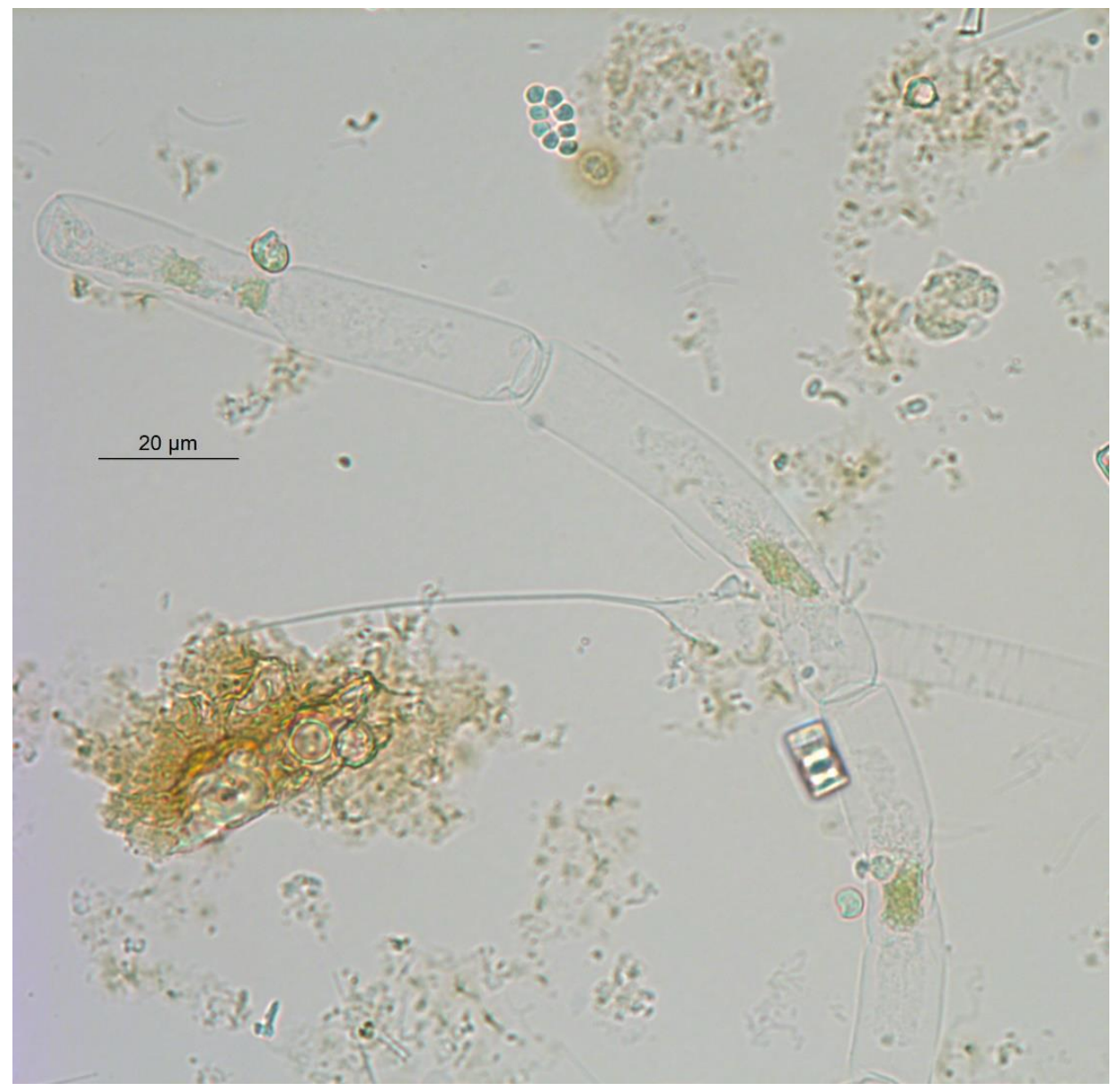


Pleurotaenium trochiscum West \& G.S. West, 1896

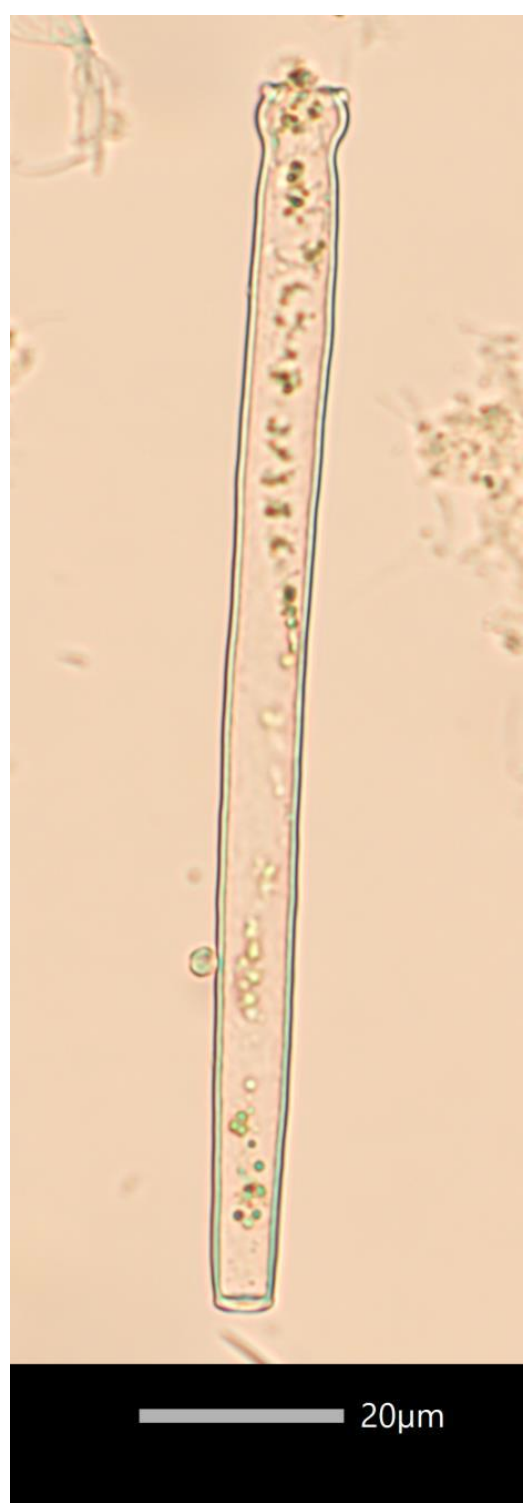


Spondylosium planum (Wolle) West \& G.S. West, 1912

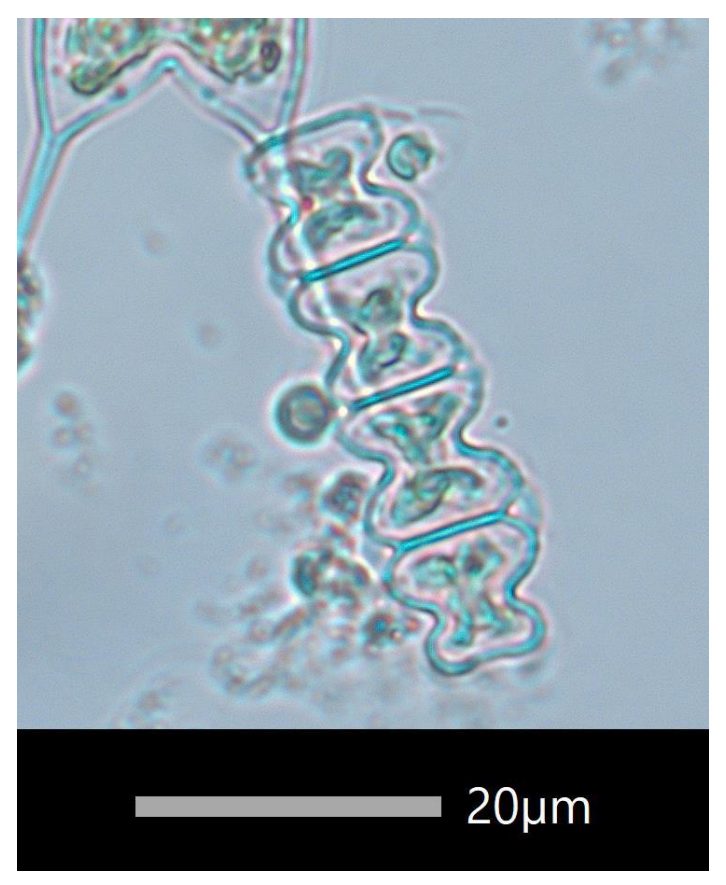

Staurastrum cf. anatinum Cooke \& Wills, 1881

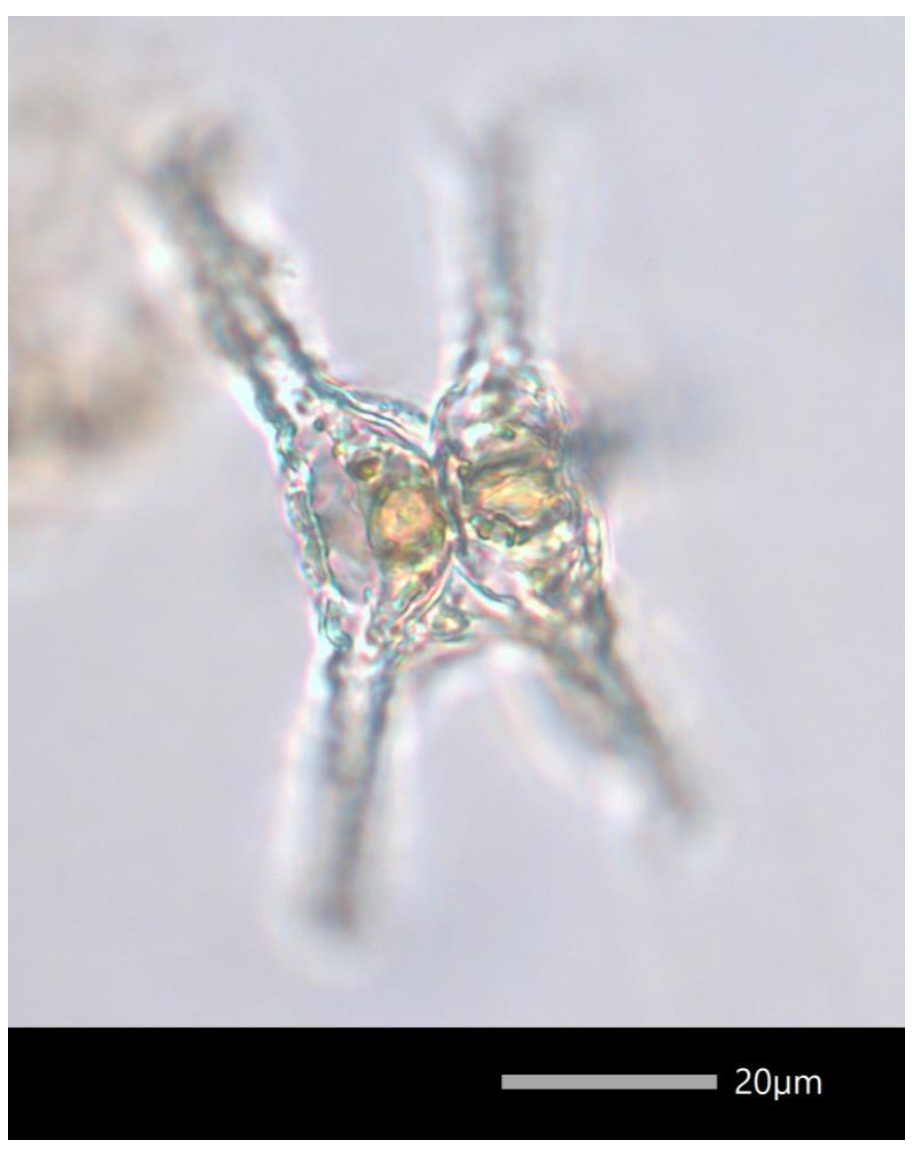


Staurastrum ankyroides Wolle, 1884

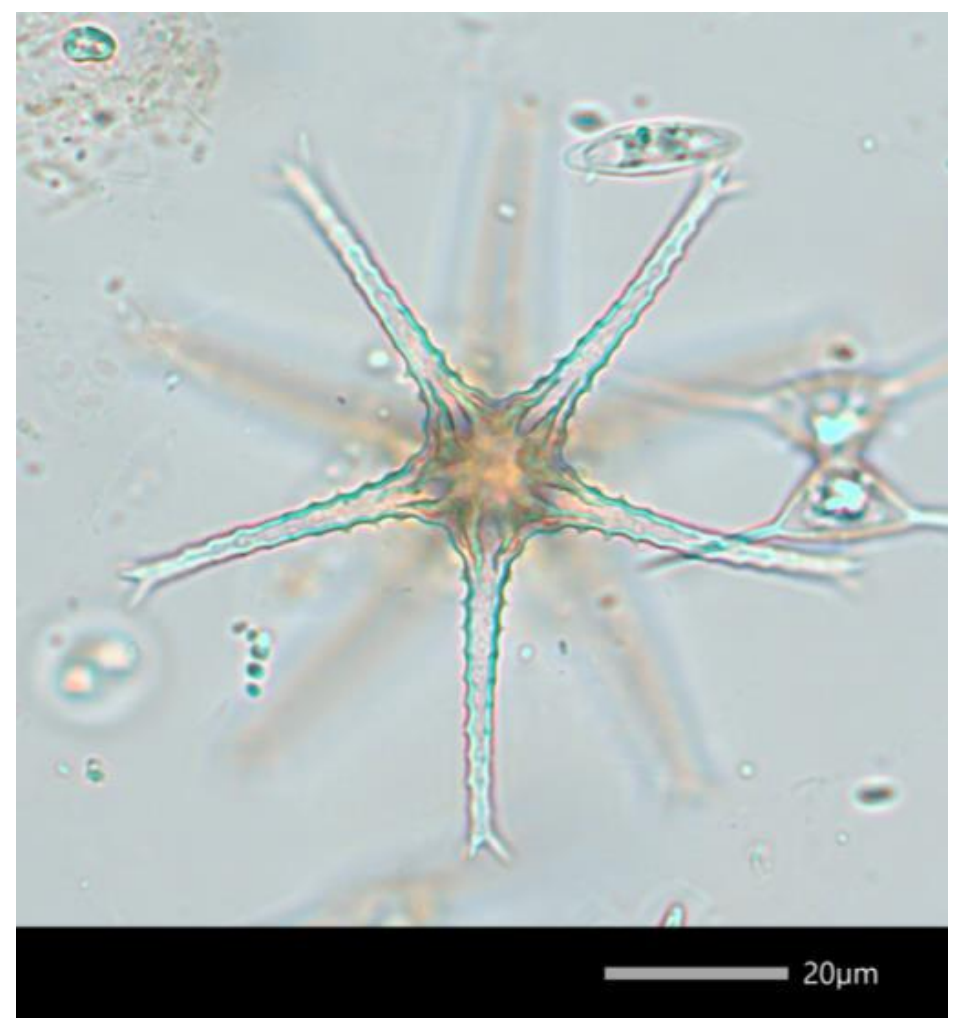

Staurastrum arachne Ralfs ex Ralfs, 1848

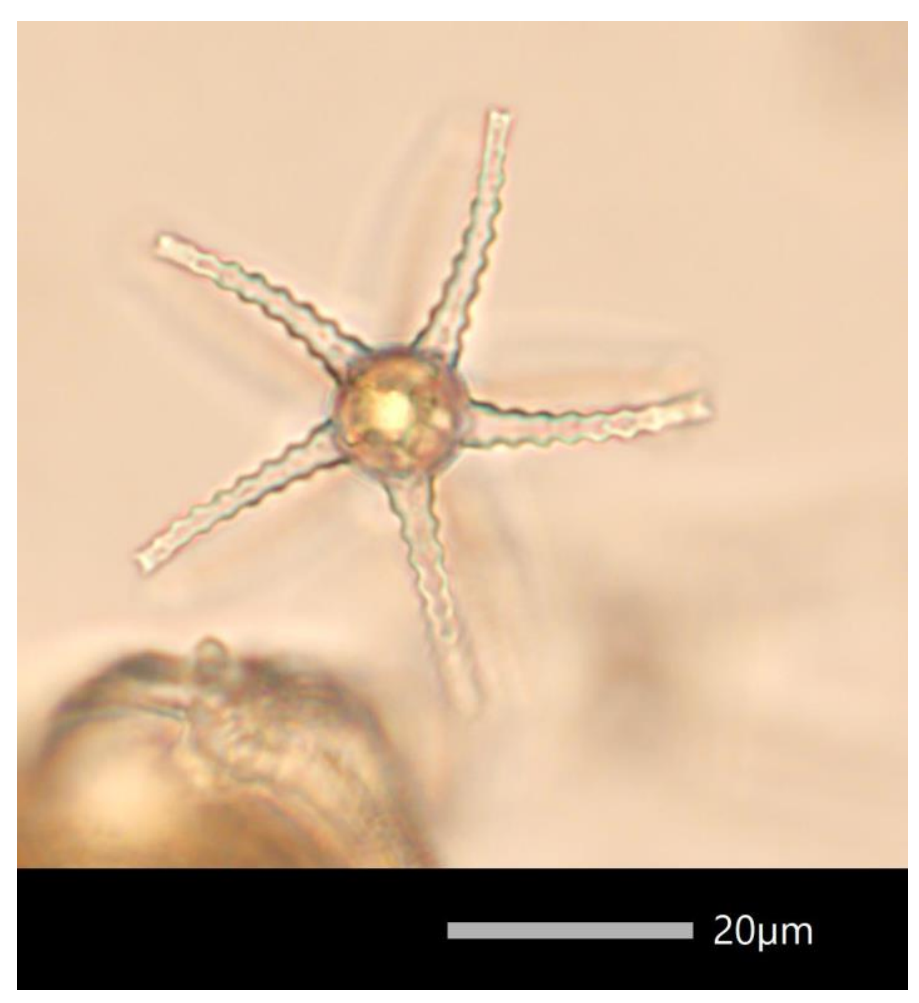


Staurastrum brachiatum Ralfs ex Ralfs, 1848

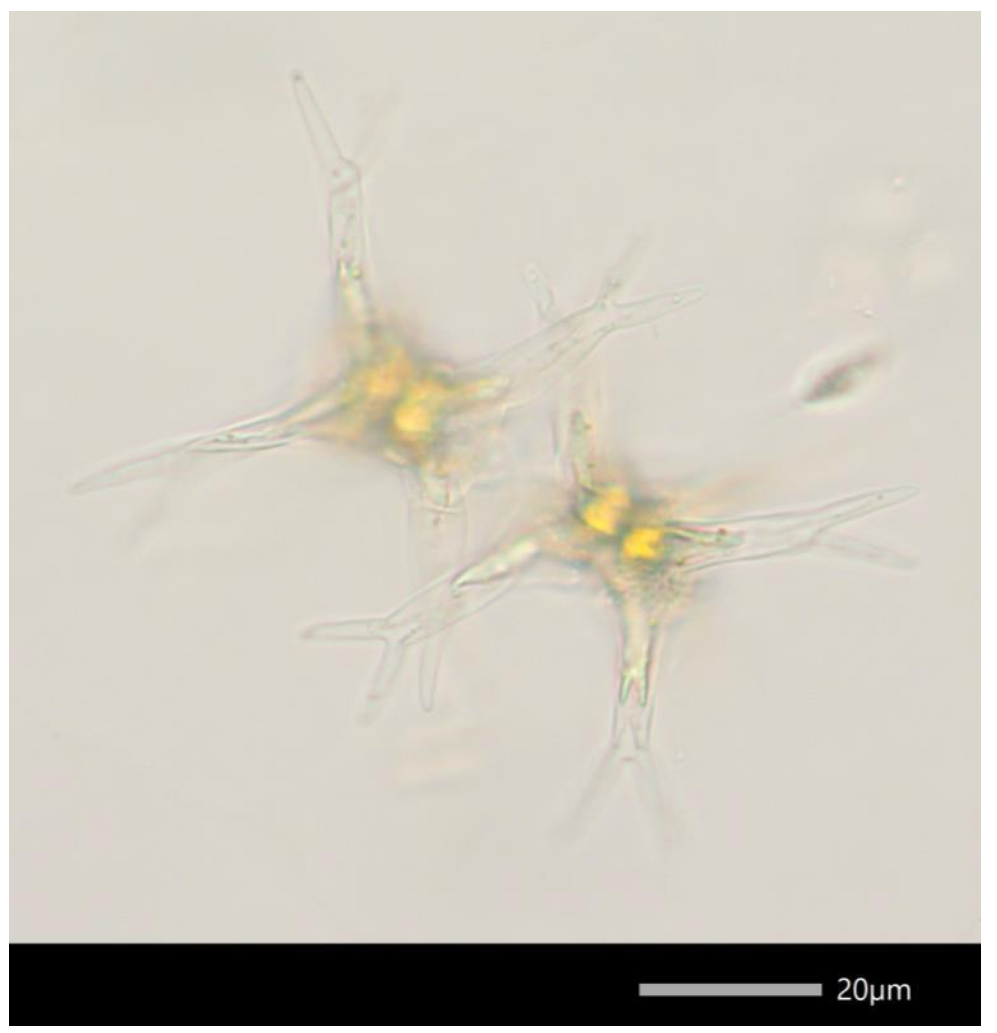

Staurastrum cf. brachioprominens v. africanum P. Bourrelly, N.D.

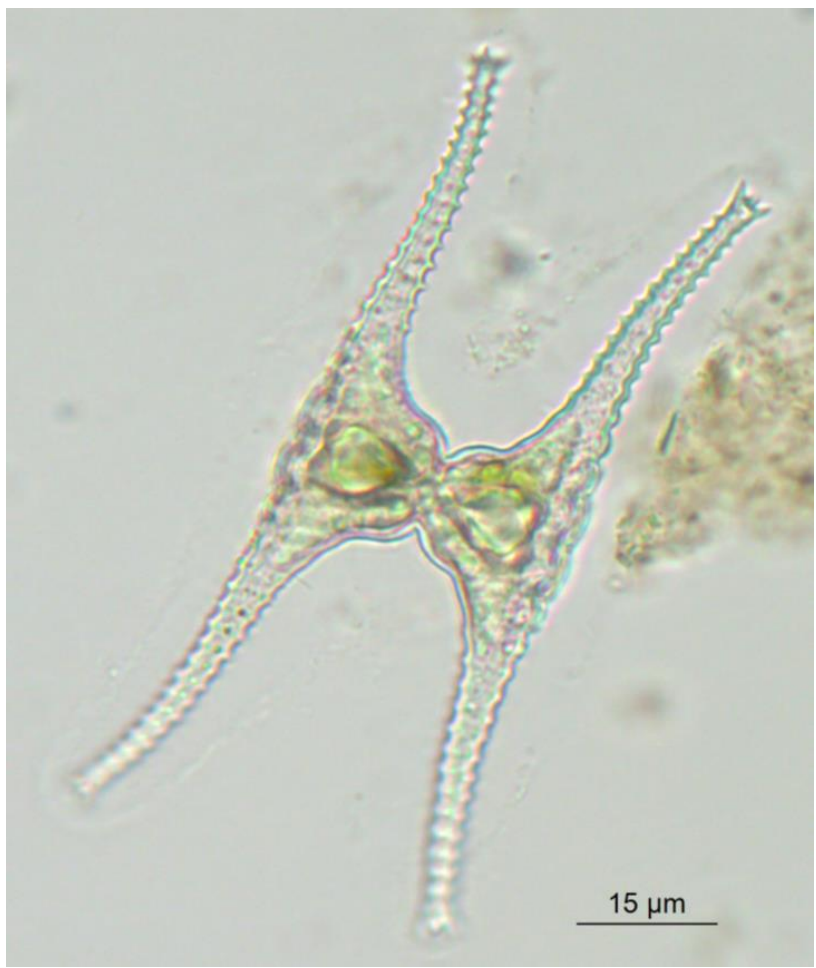


Staurastrum cerastes P. Lundell, 1871
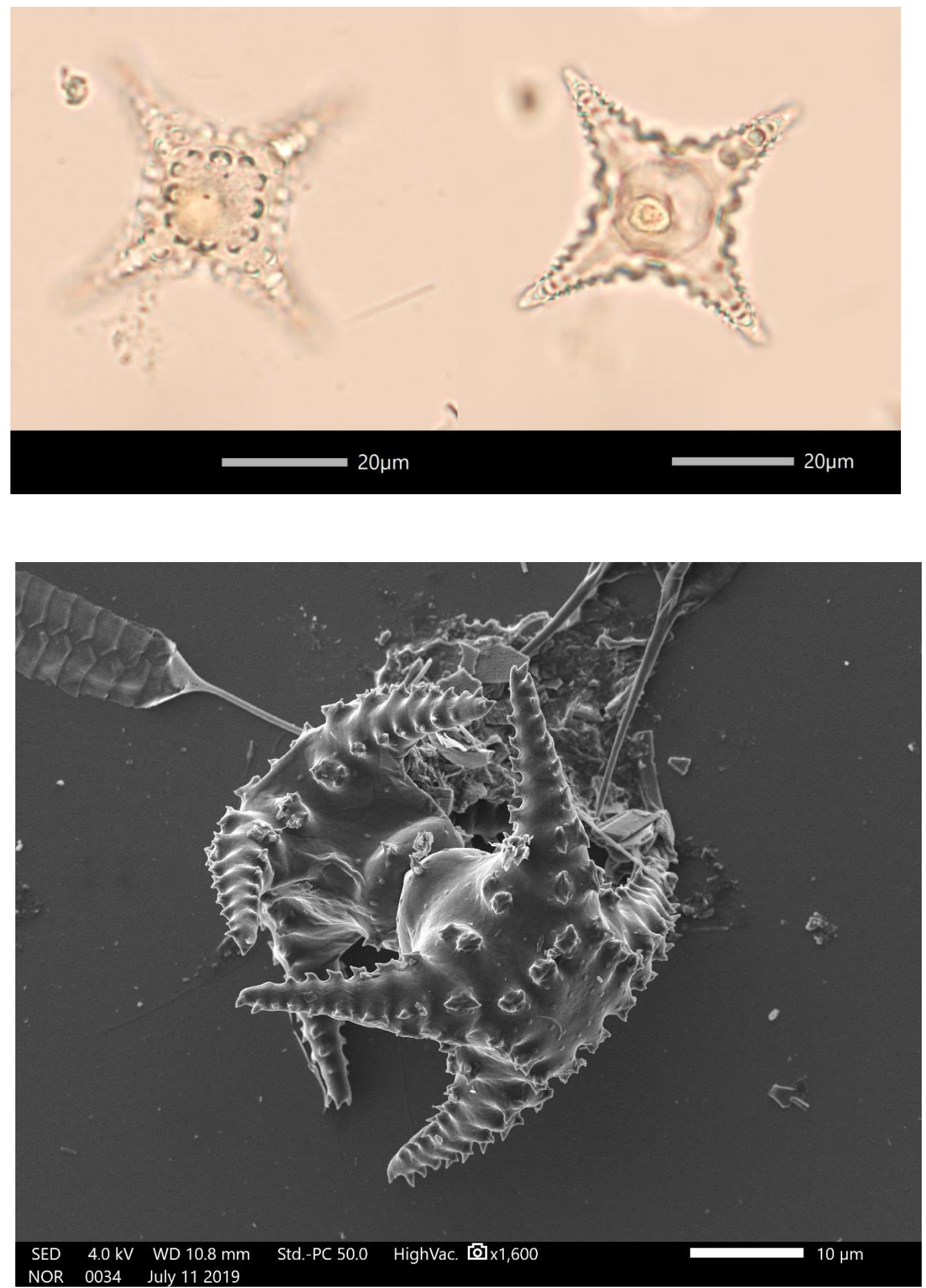
Staurastrum cingulum (West \& G.S. West) G.M. Smith, 1922

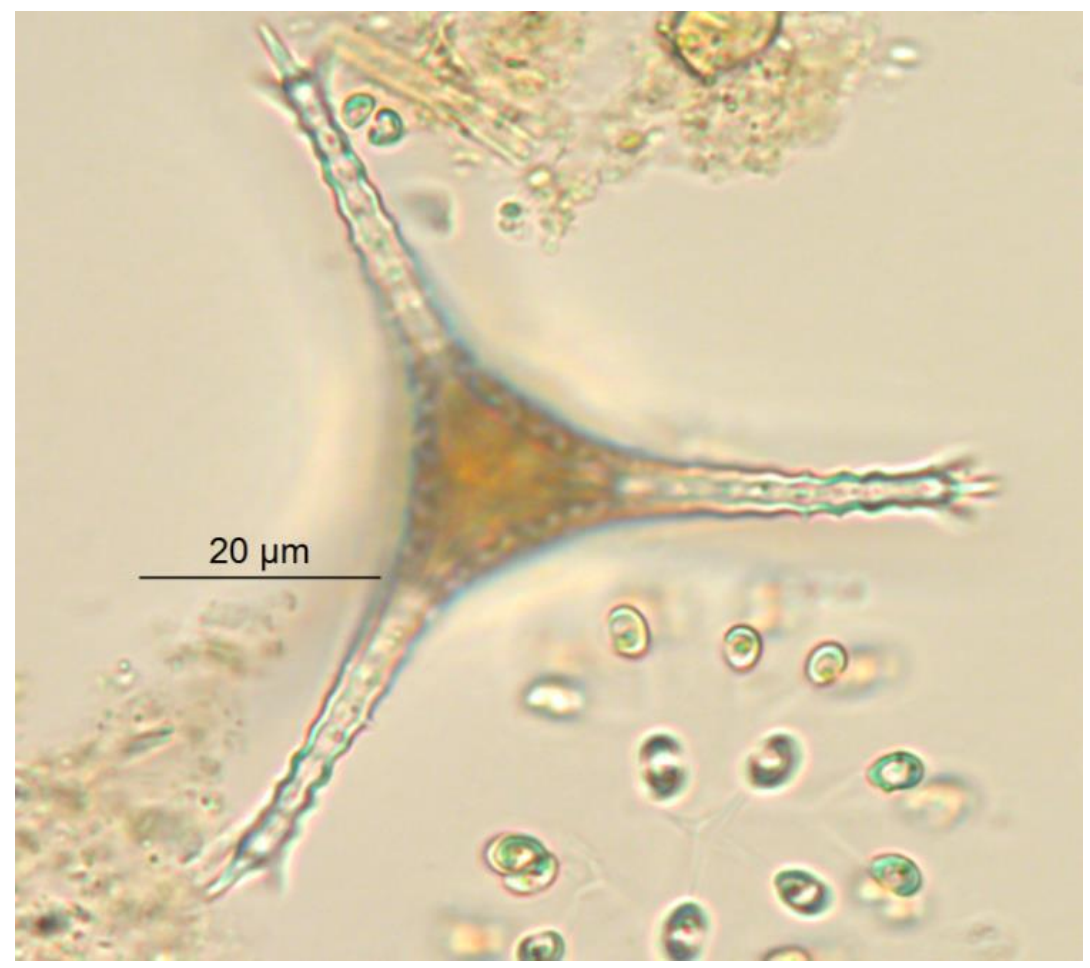

Staurastrum comptum (Wolle, N.D.)

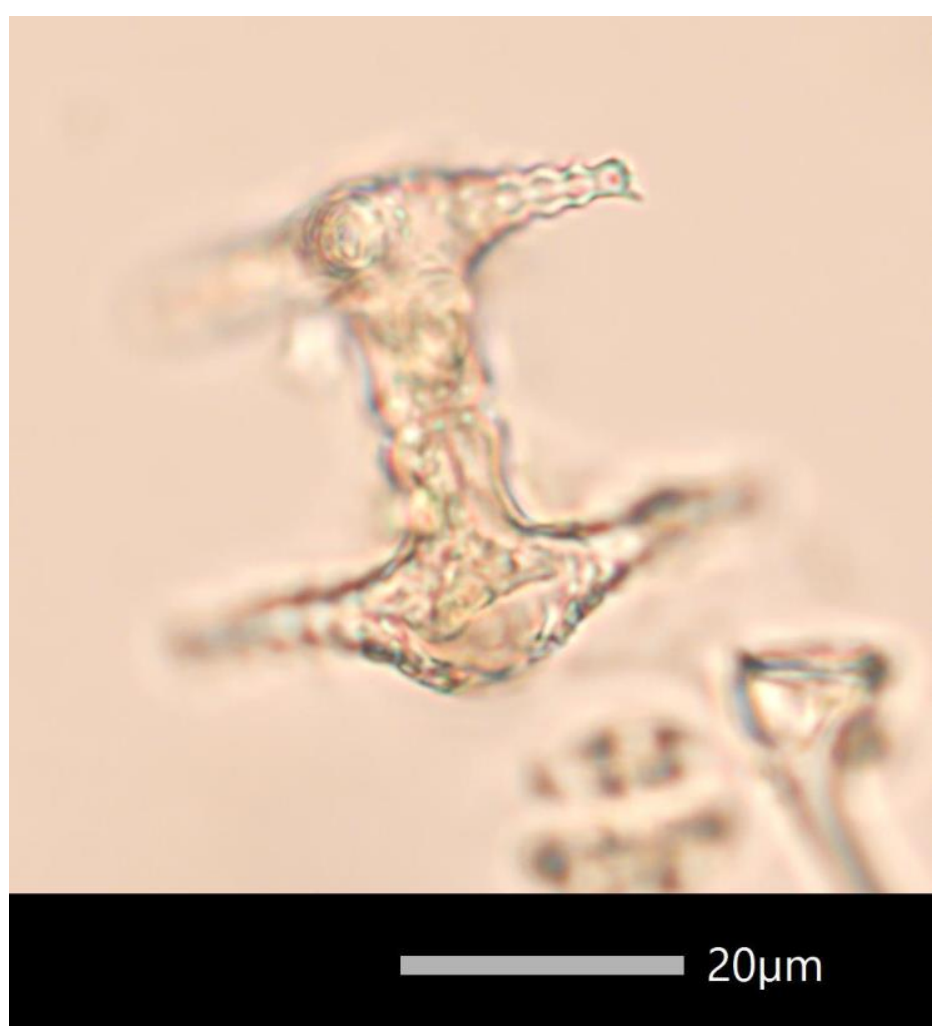


Staurastrum cf. cyclofurcatum A.M. Scott \& Grönblad, 1957

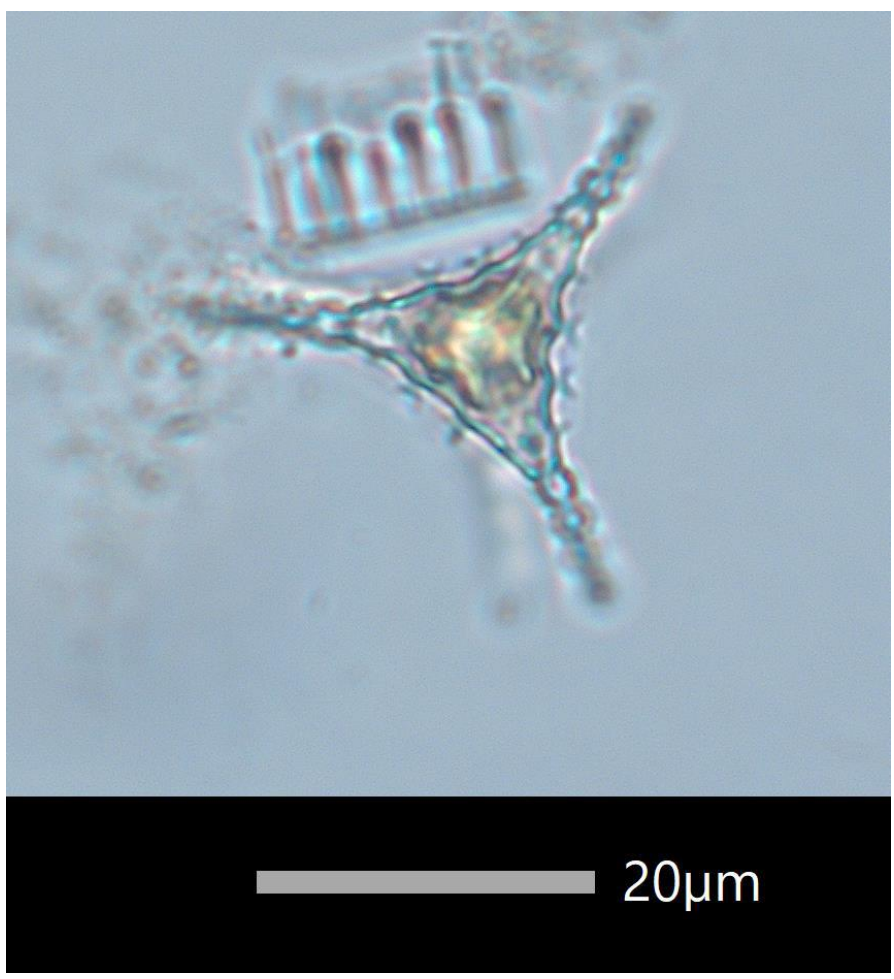

Staurastrum diacanthum v. evolutum Scott \& Grönblad, 1957

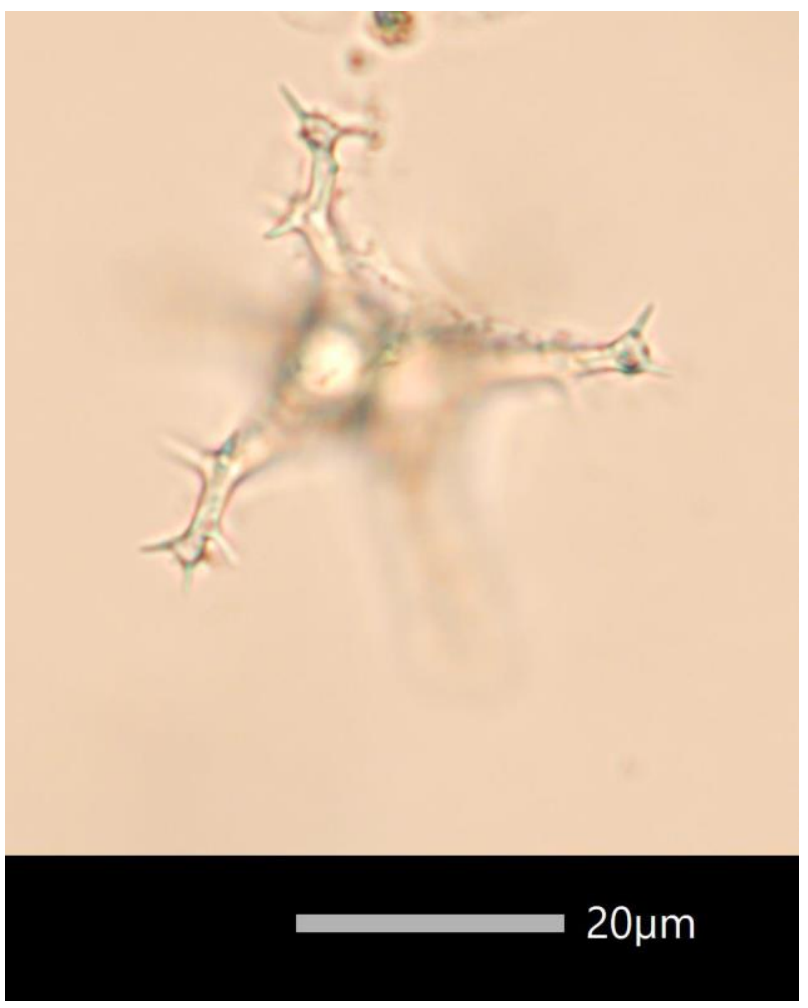


Staurastrum cf. gracile Ralfs ex Ralfs, 1848

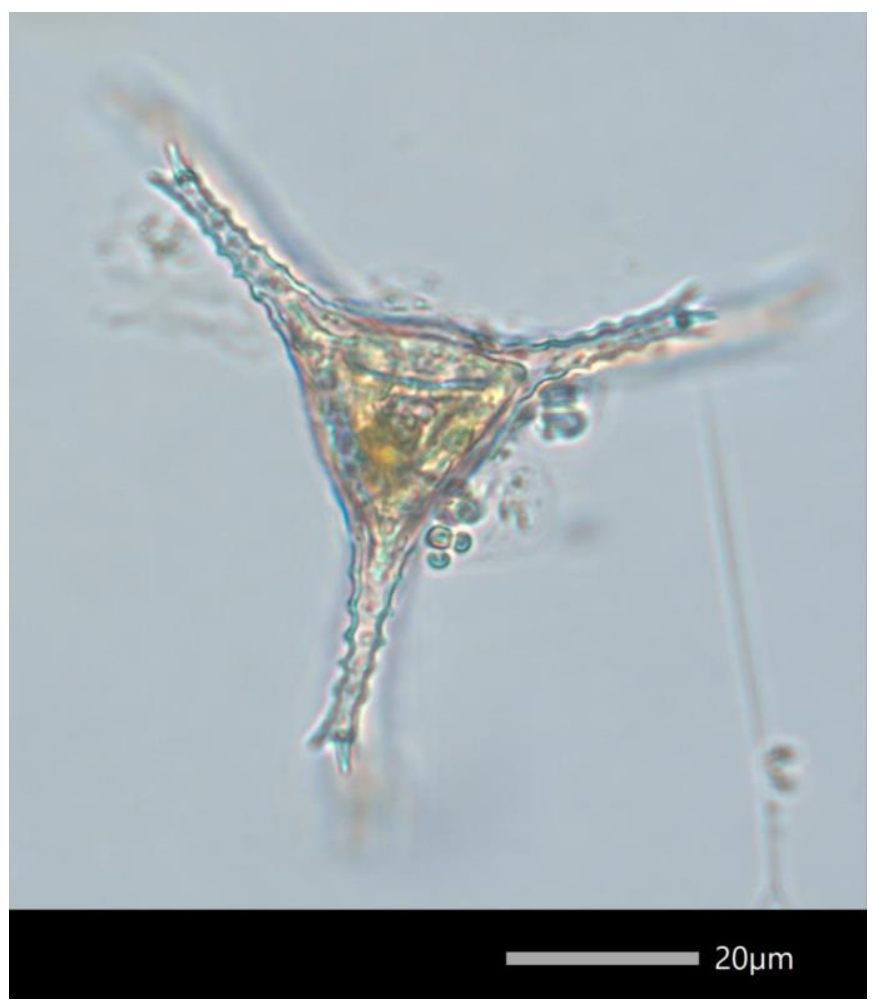

Staurastrum grallatorium Nordstedt, 1870

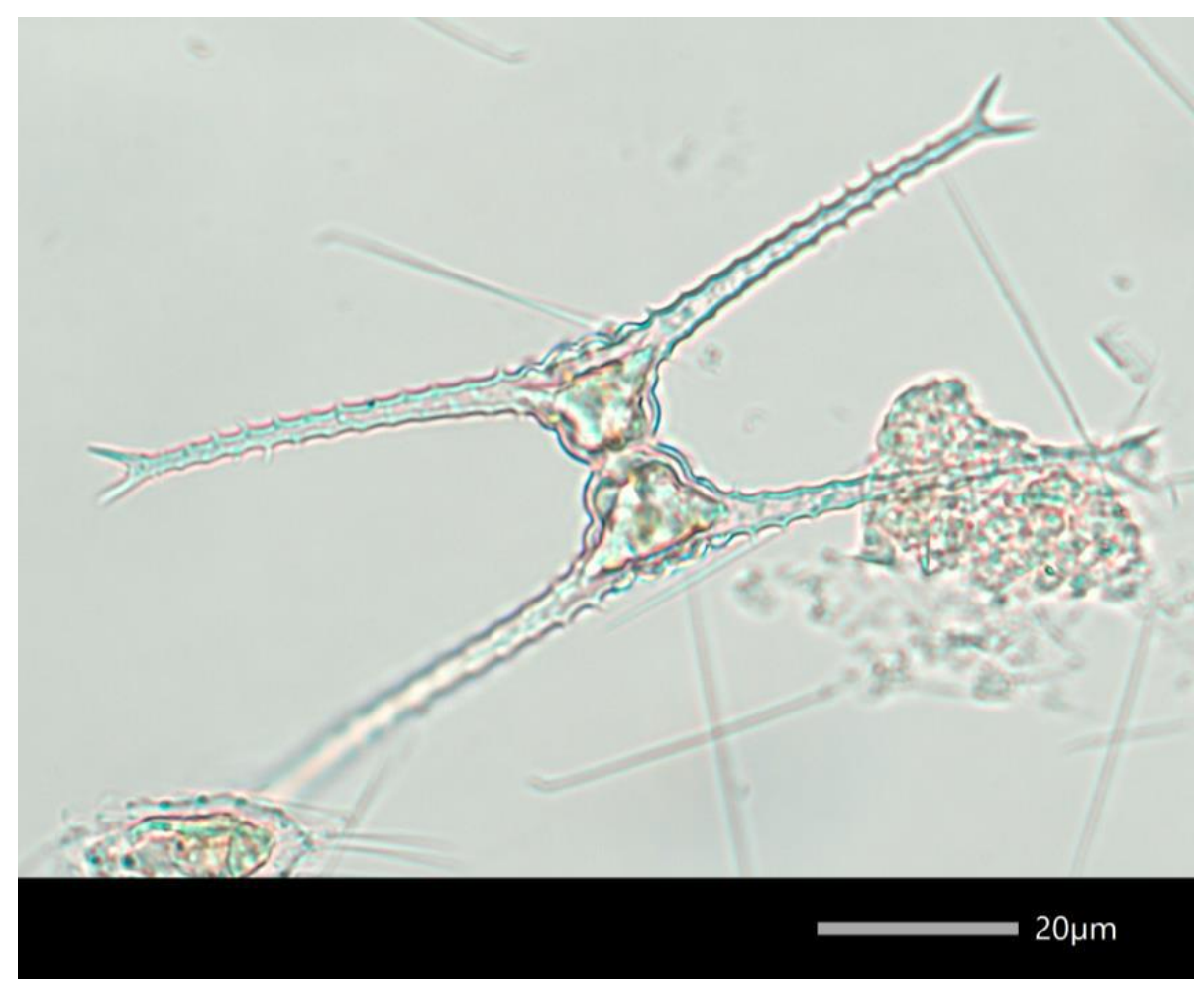


Staurastrum hystrix Ralfs, 1848

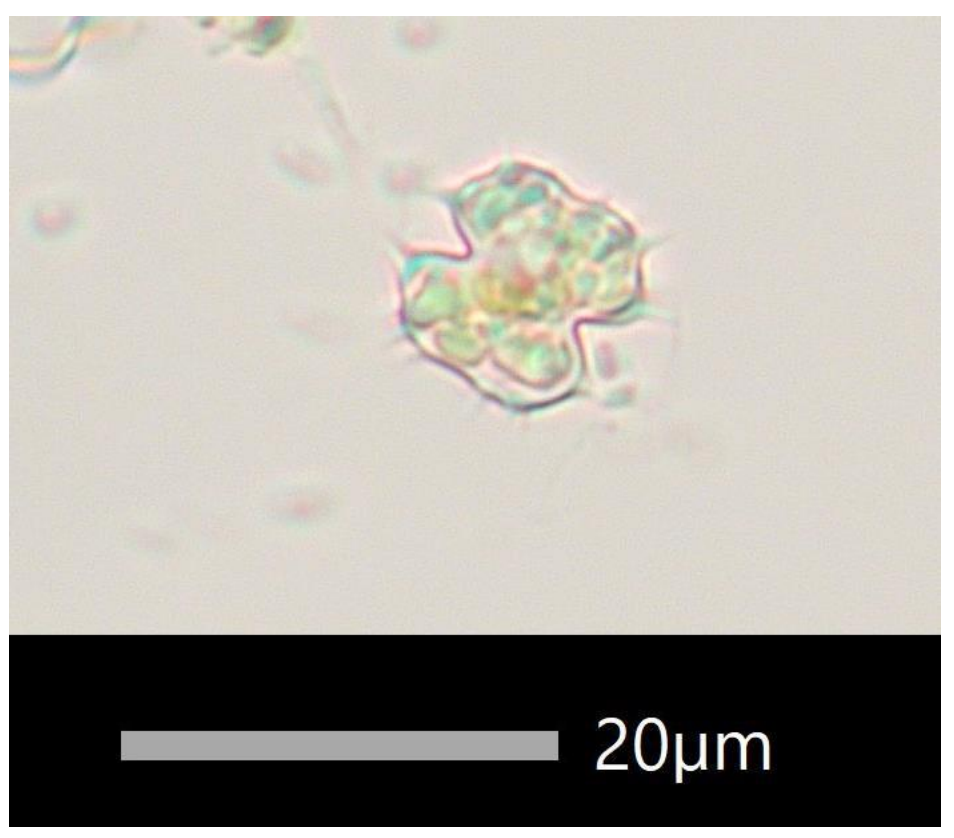

Staurastrum hystrix v. floridense A.M. Scott \& Grönblad, 1957

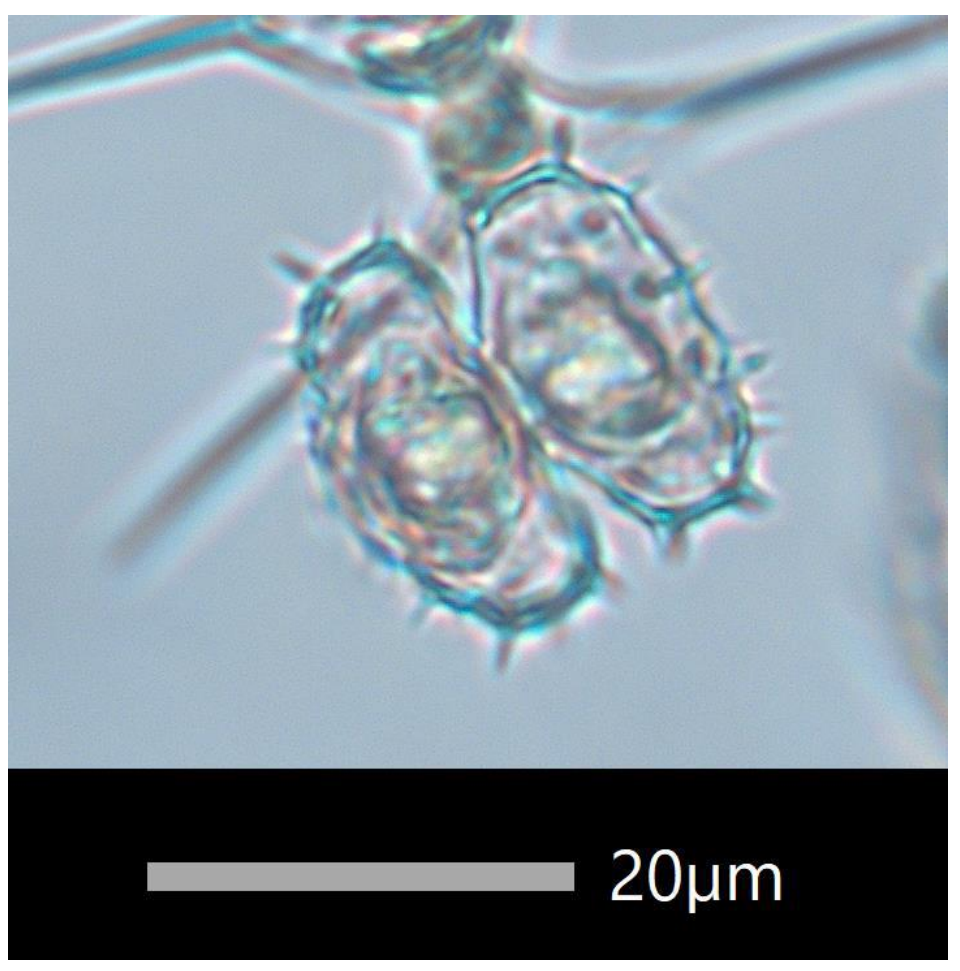


Staurastrum inconspicuum Nordstedt, 1873

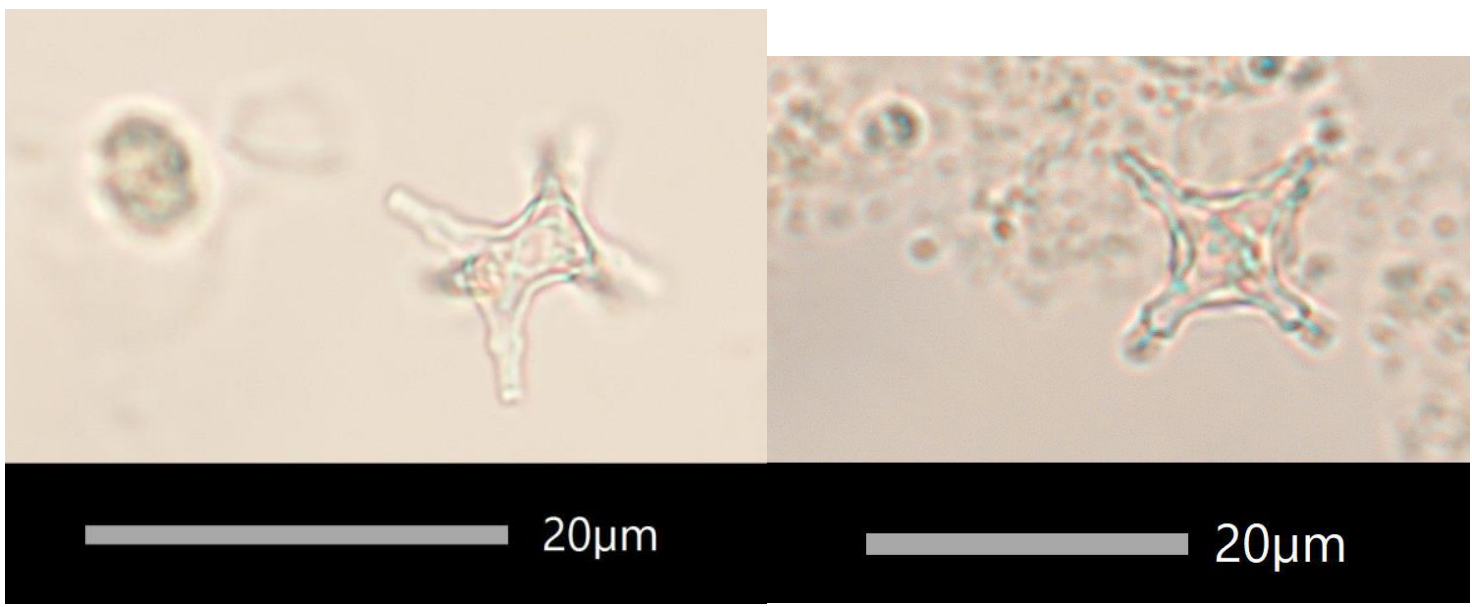

Staurastrum cf. johnsonii v. depauperatum G.M. Smith, 1924

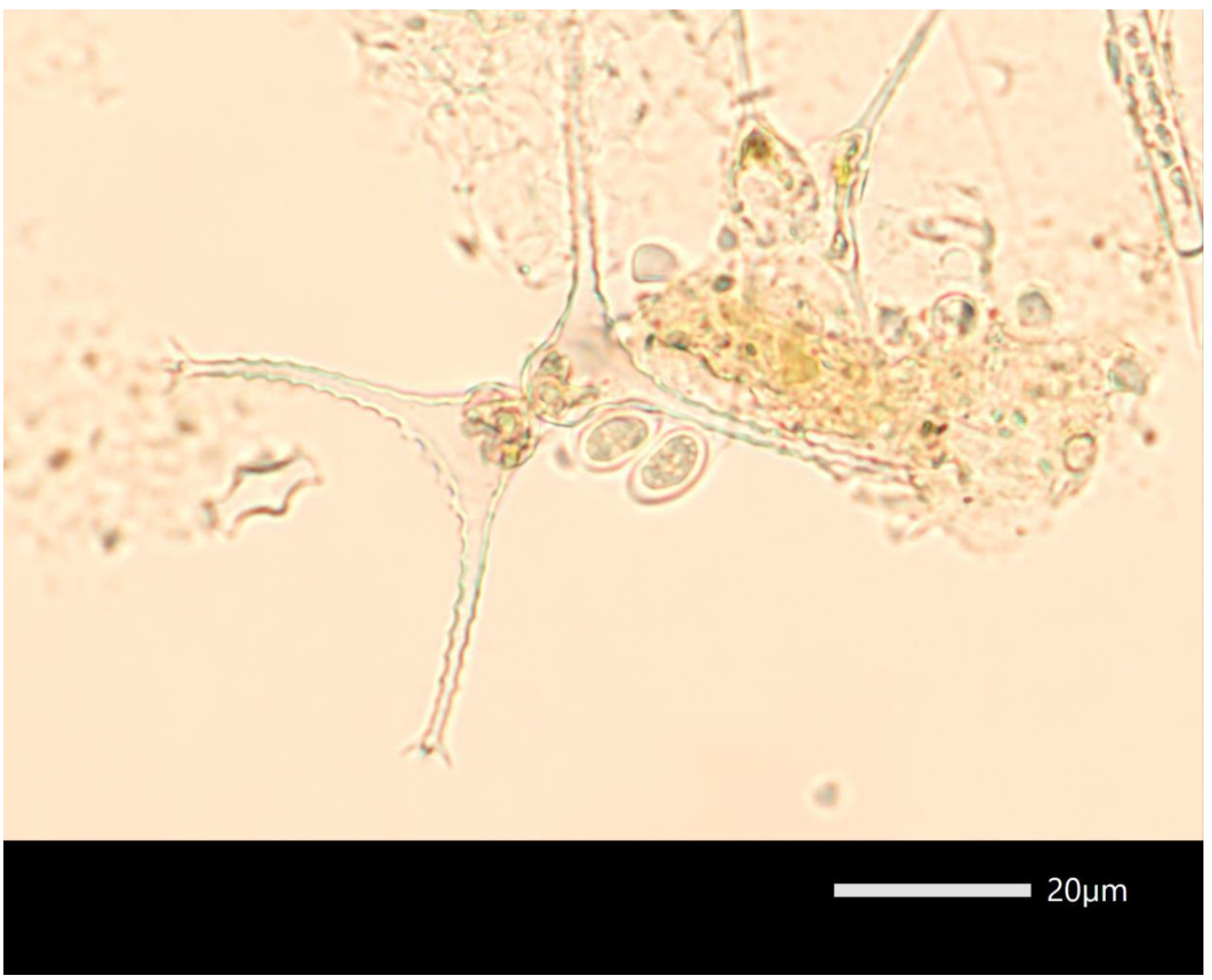


Staurastrum leptocladum Nordstedt, 1870

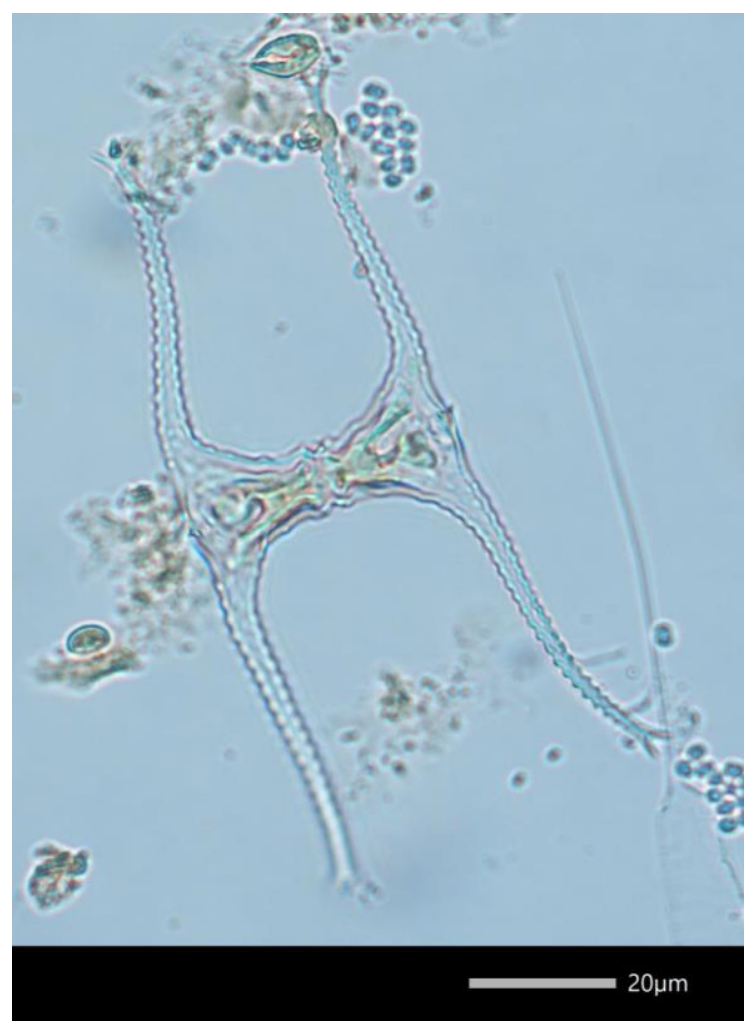

Staurastrum leptocladum v. sinuatum Wolle, 1883

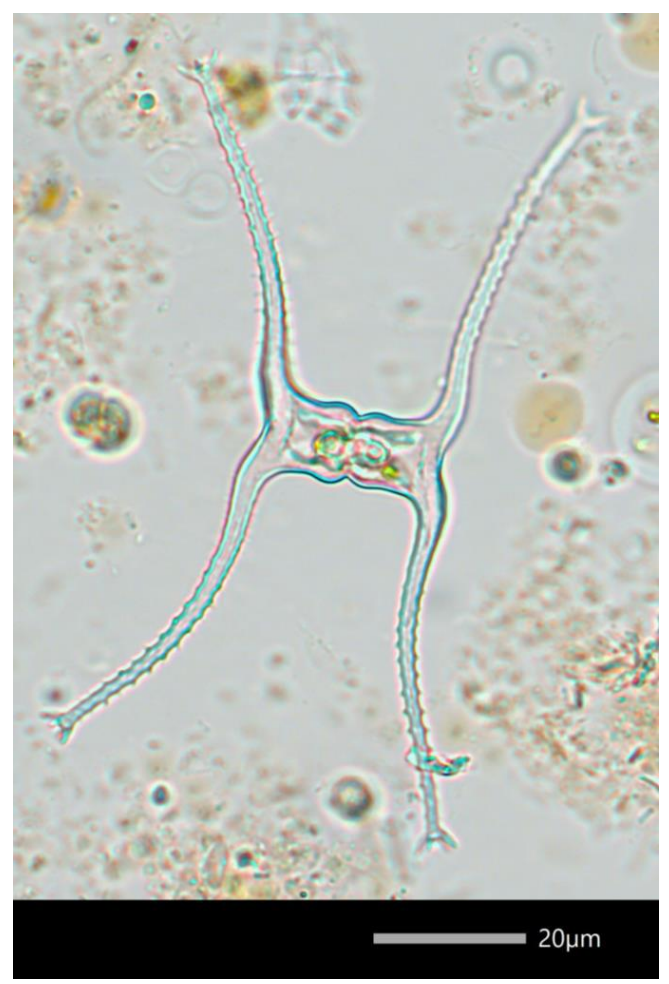


Staurastrum longipes (Nordstedt) Teiling, 1946

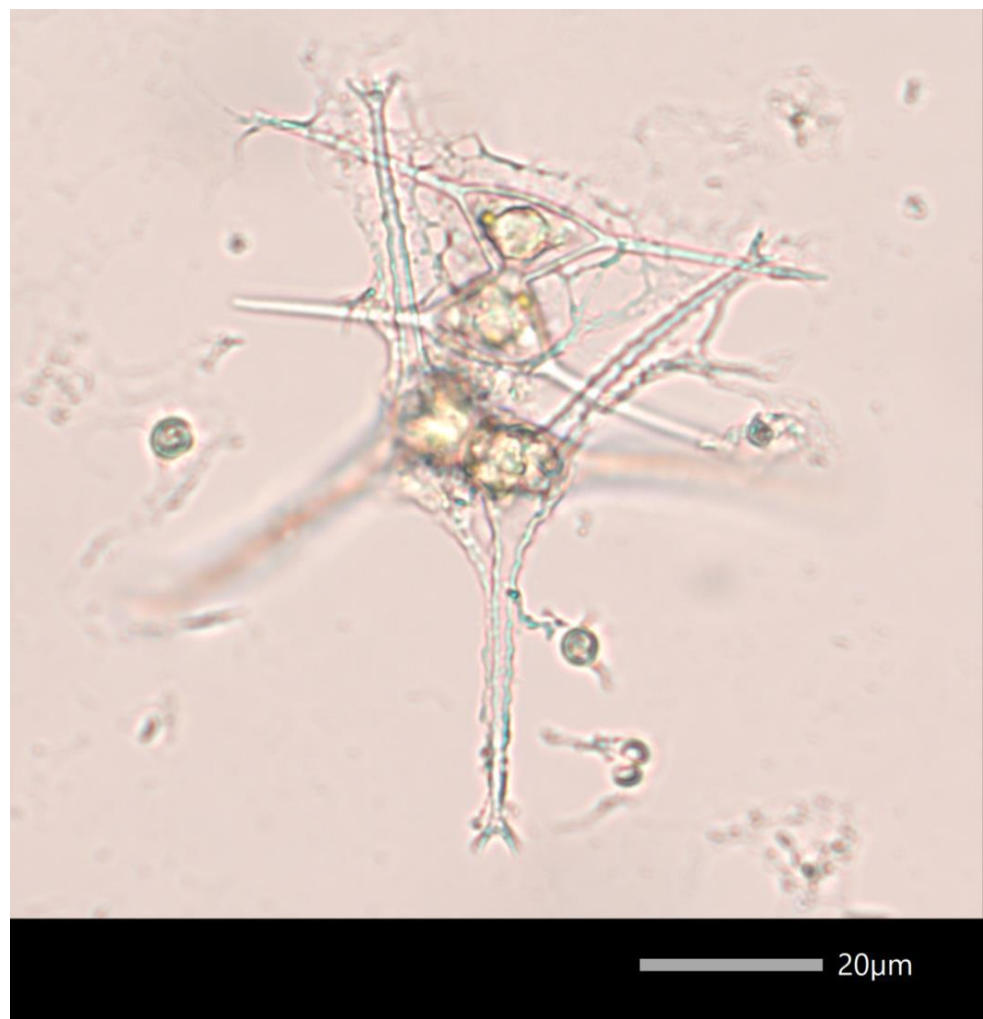

Staurastrum longispinum v. praelongum A.M. Scott \& Grönblad, N.D.

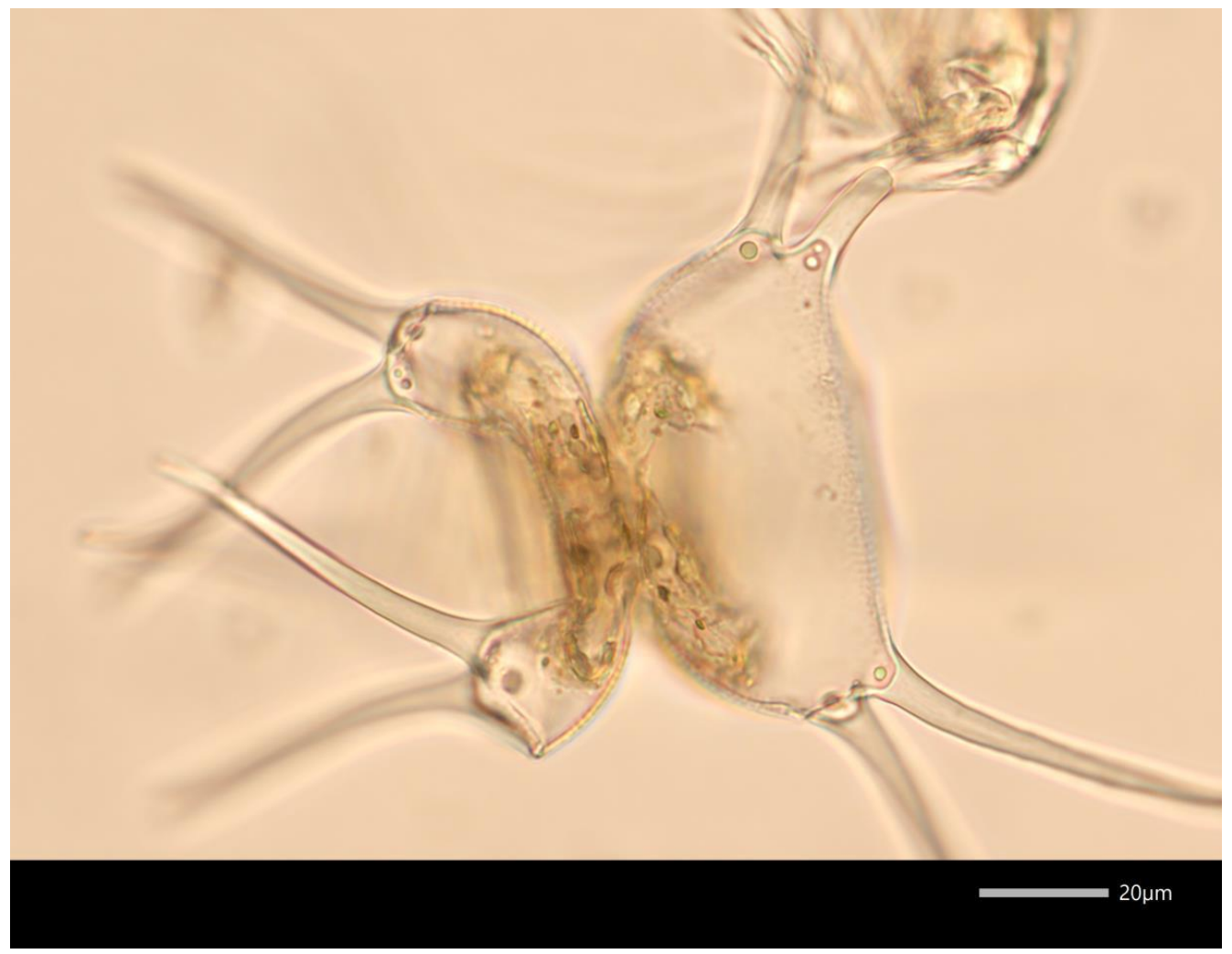


Staurastrum minnesotense Wolle, 1885

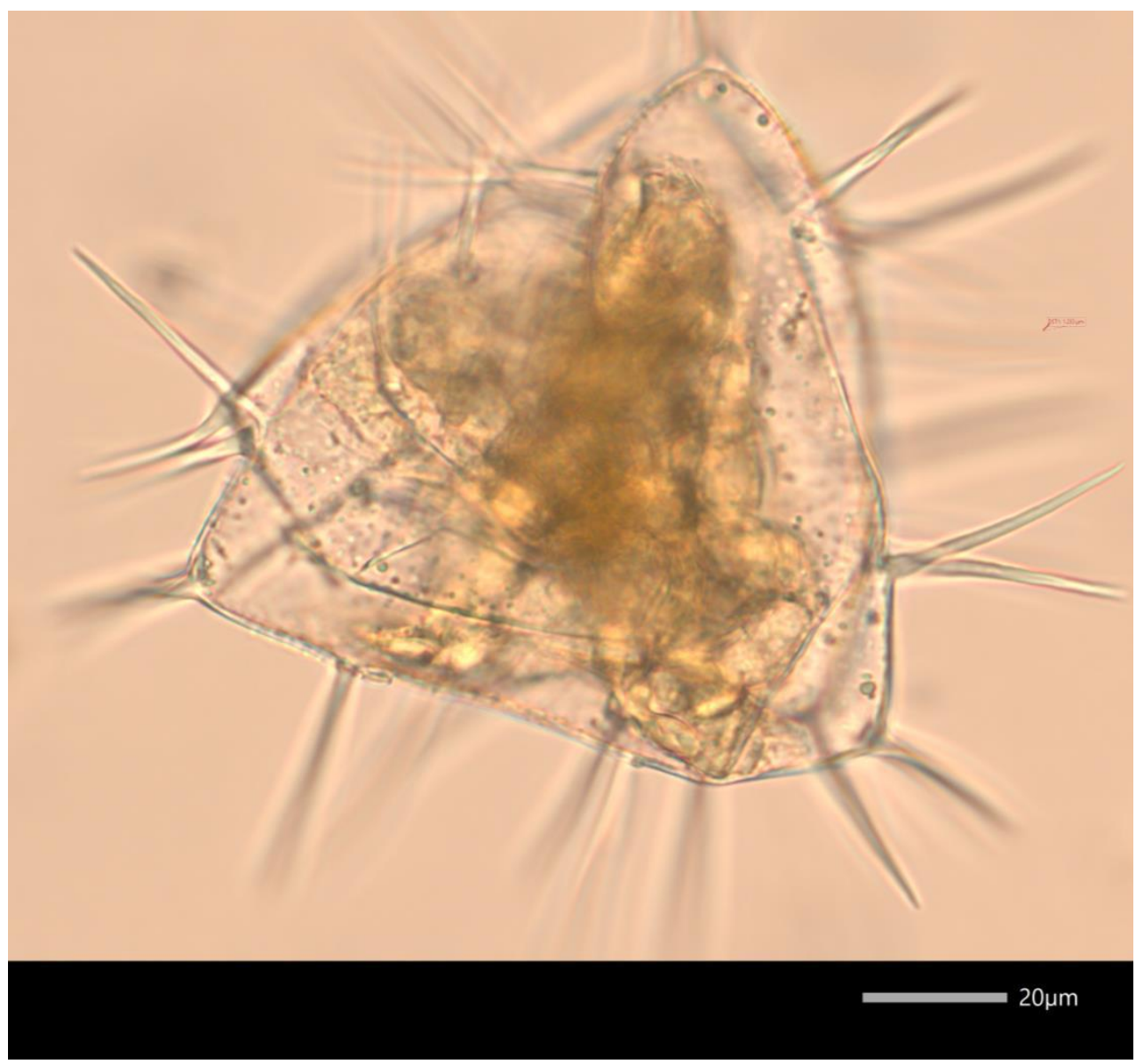


Staurastrum cf. natator v. crassum West \& G.S. West, N.D.
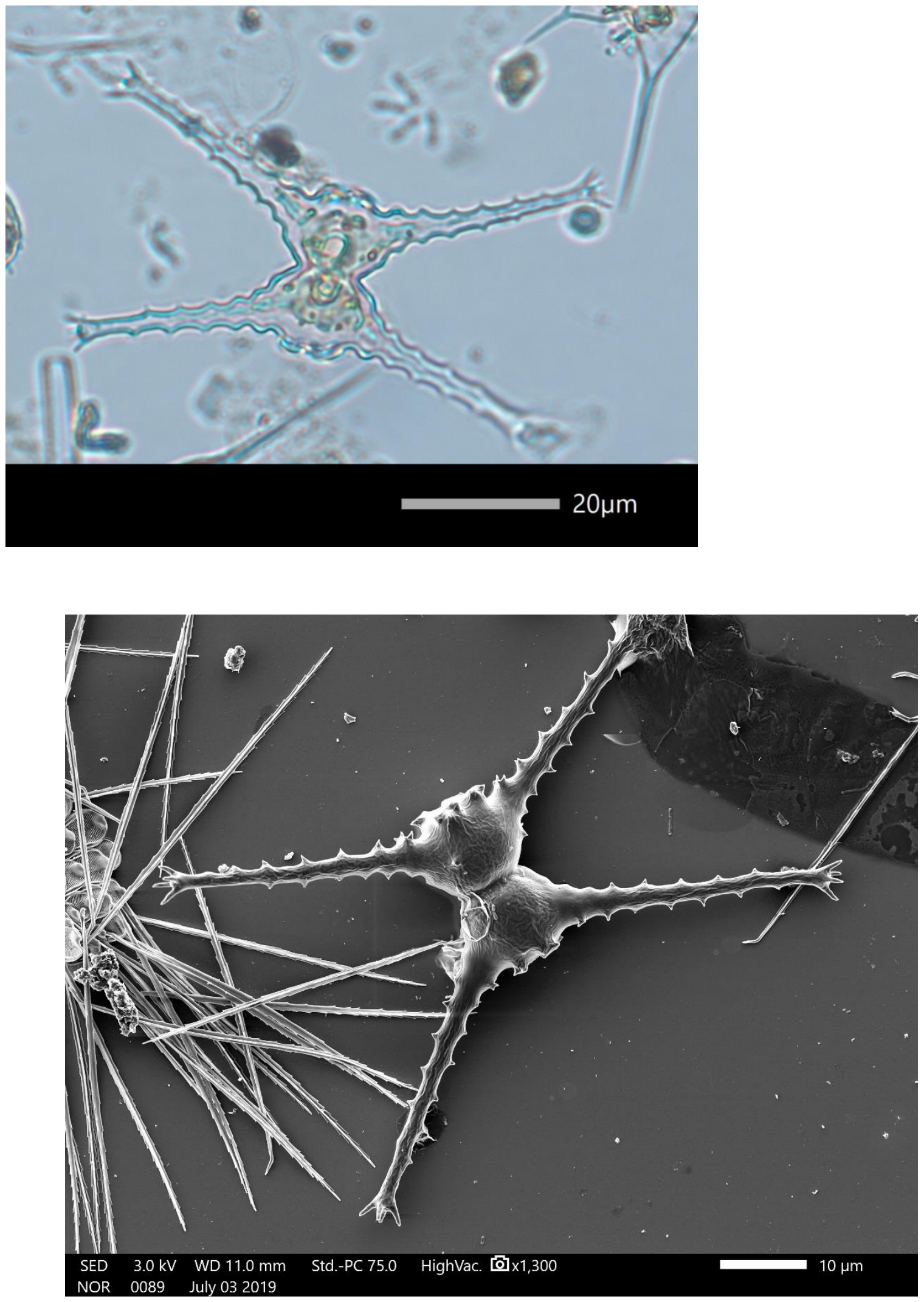
Staurastrum novae-ceasareae Wolle, 1880
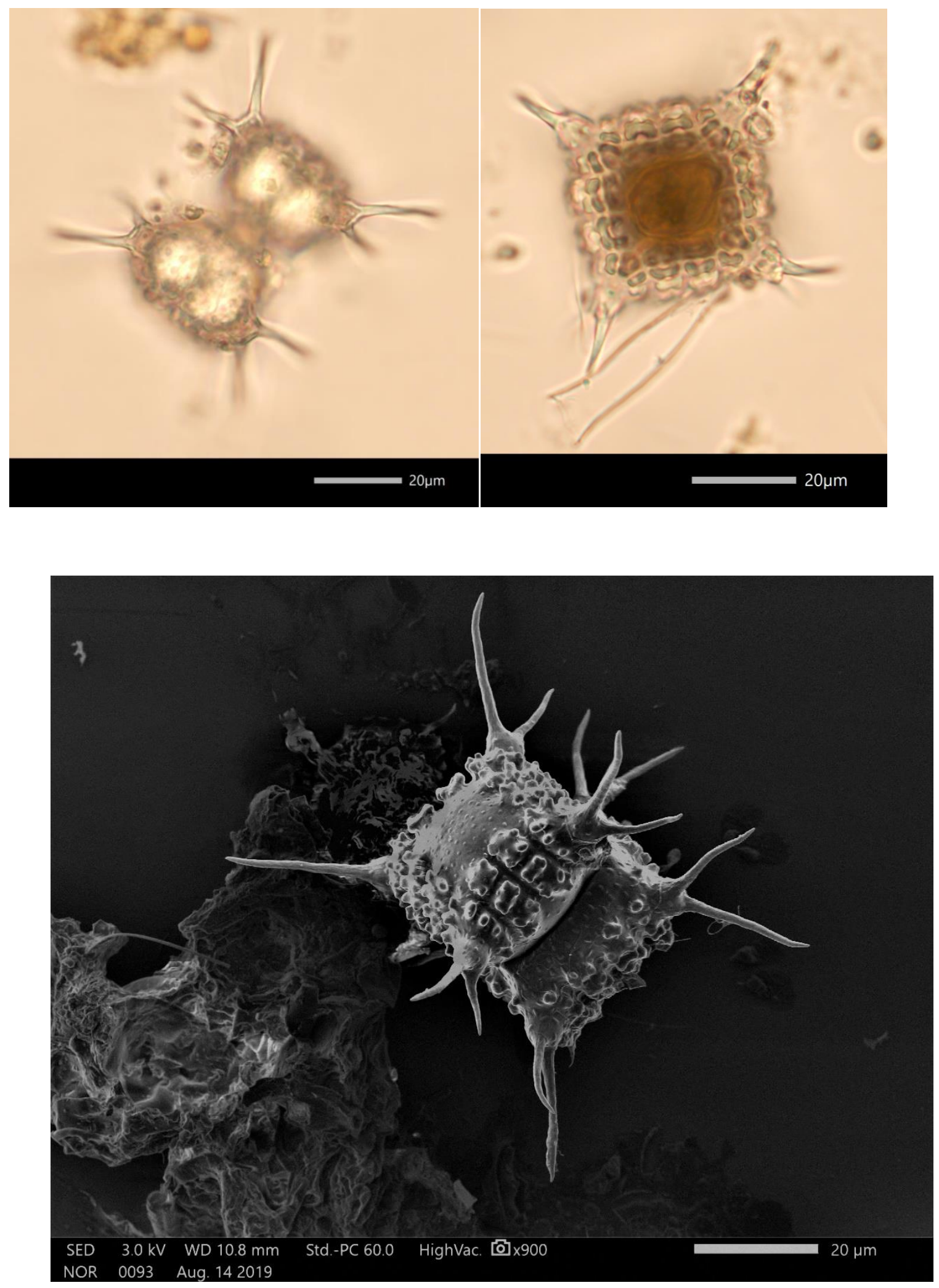
Staurastrum octoverrucosum A.M. Scott \& Grönblad, 1957

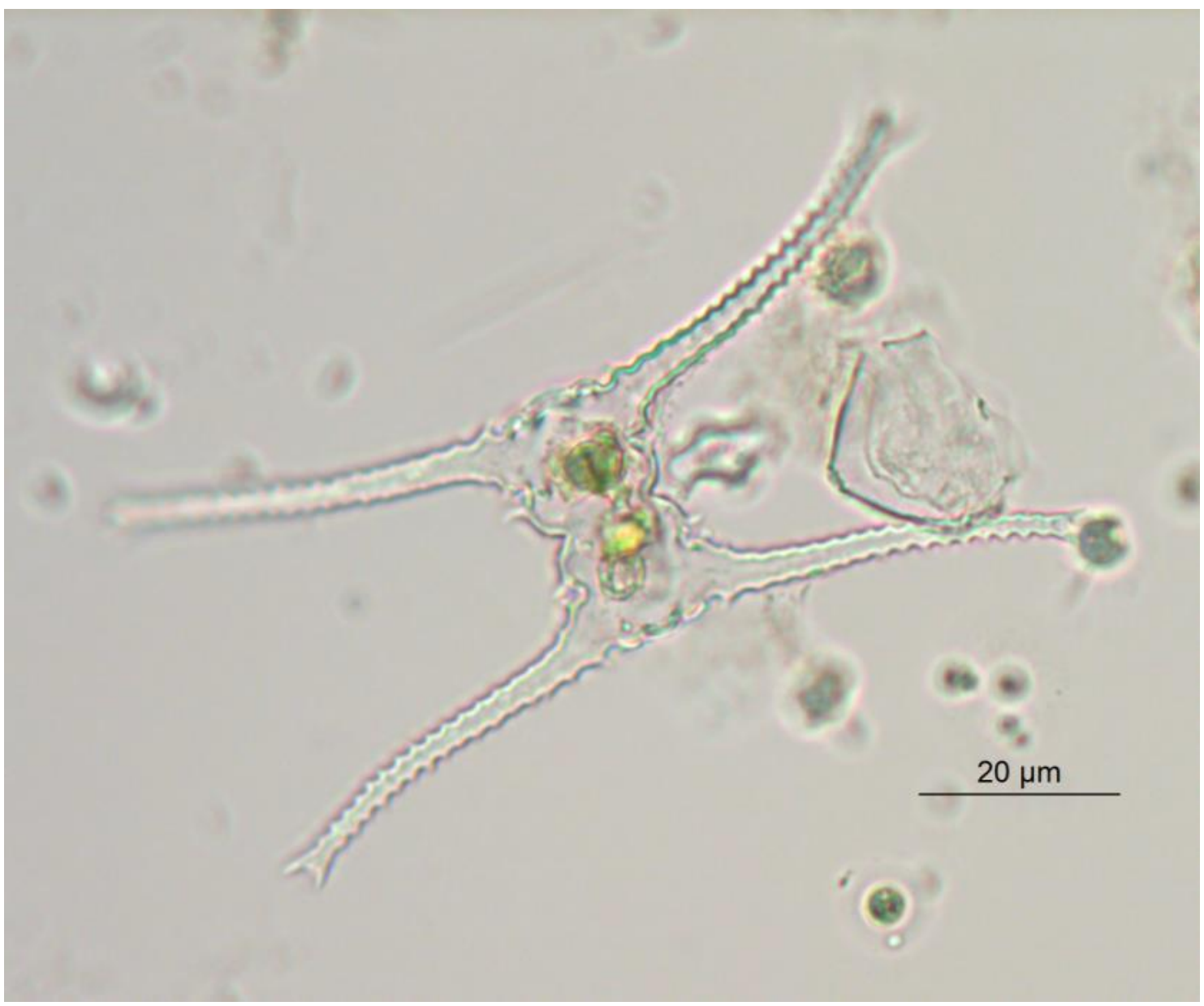


Staurastrum ophiura P. Lundell, 1871
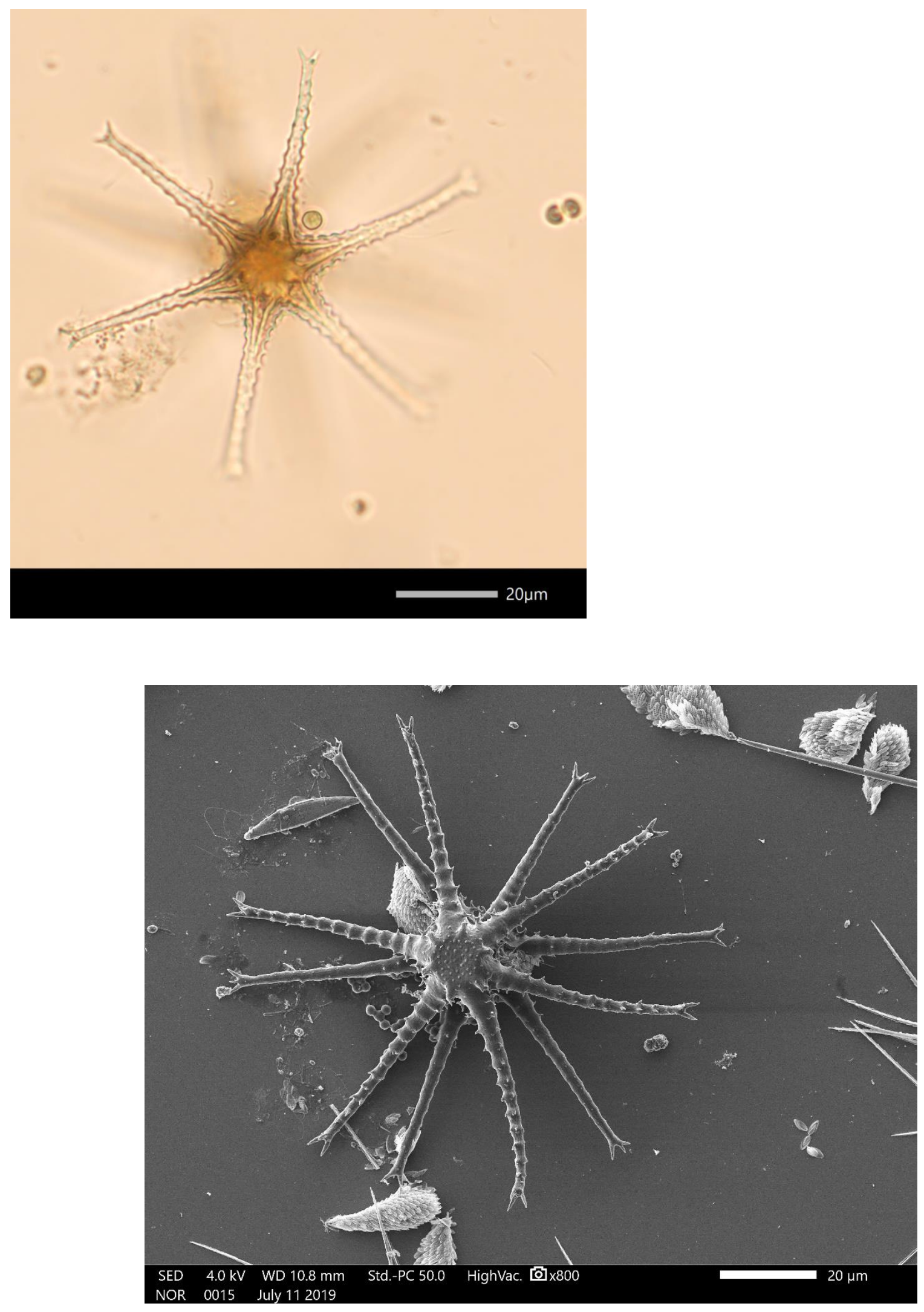
Staurastrum pinnatum v. reductum Willi Krieger, N.D.

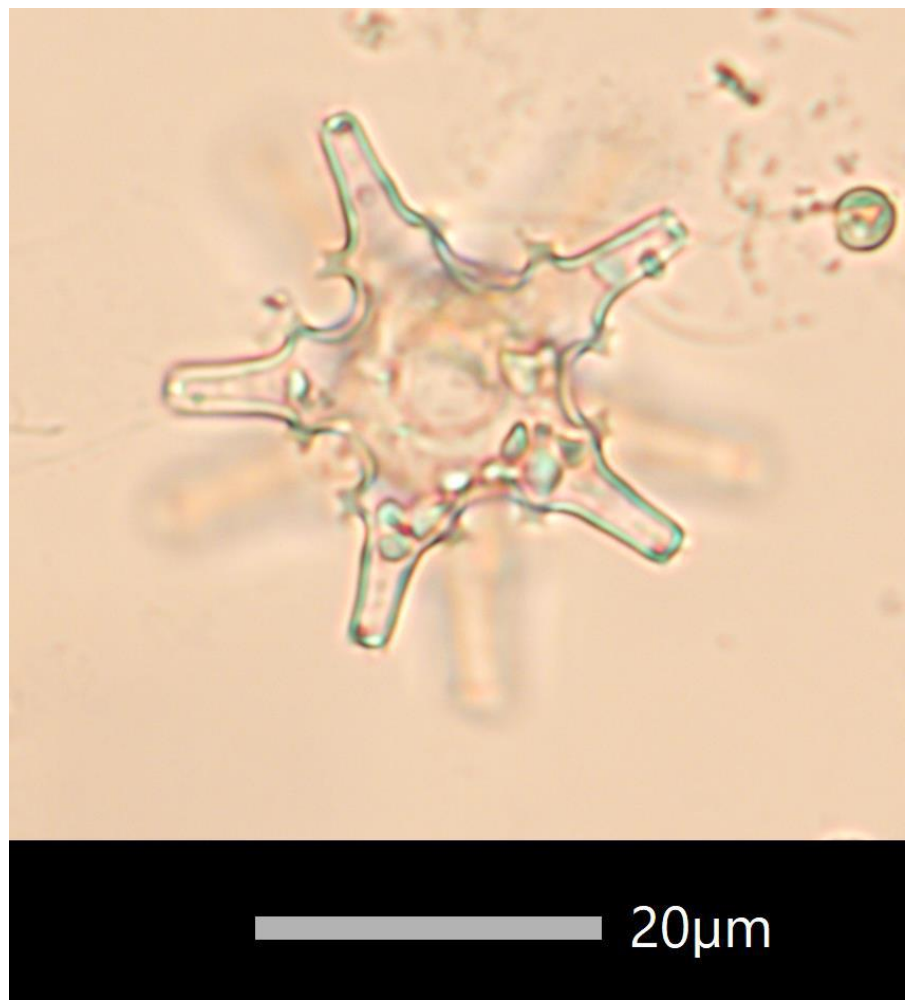

Staurastrum punctulatum Brébisson, 1848

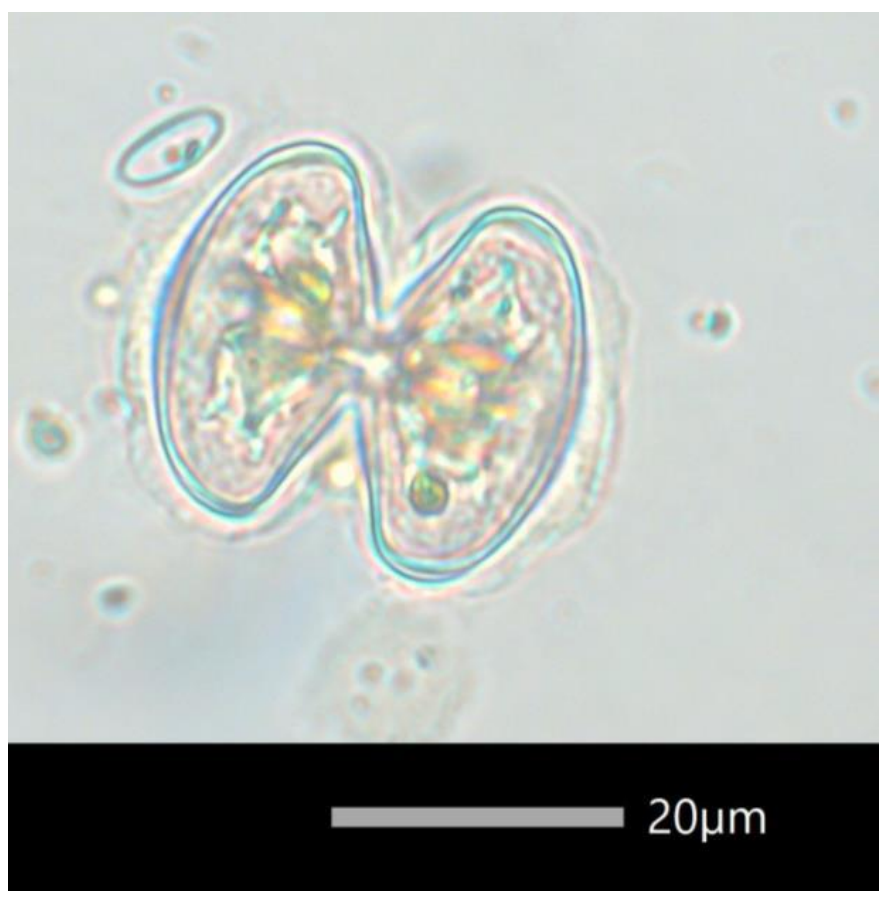


Staurastrum rectangulare Borge, 1896

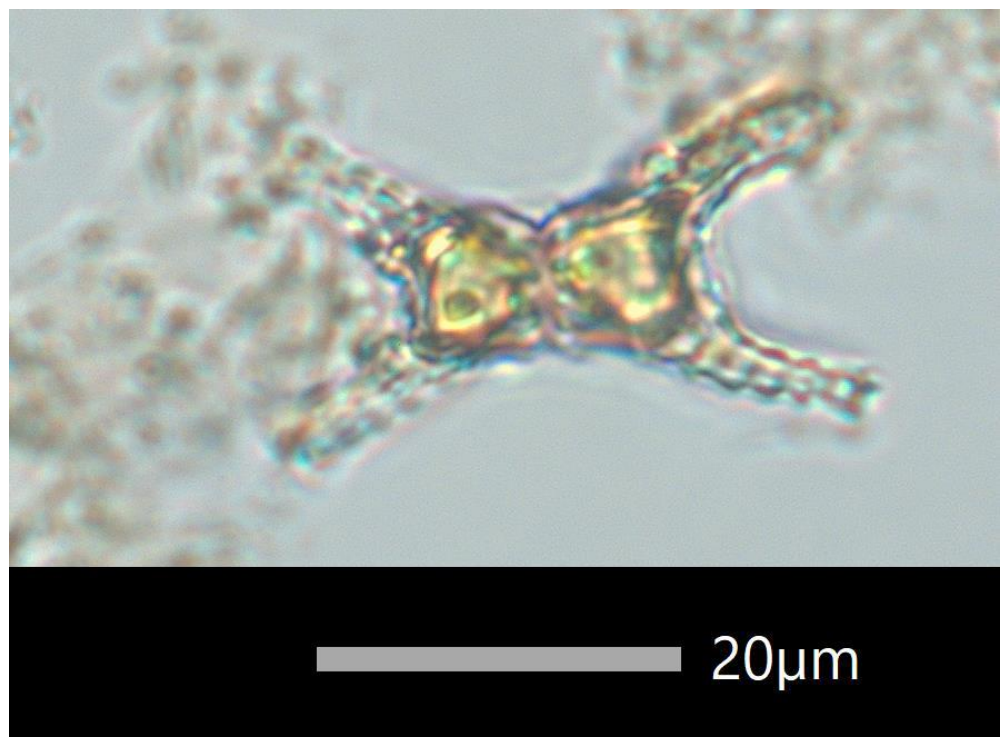

Staurastrum rotula Nordstedt, 1869

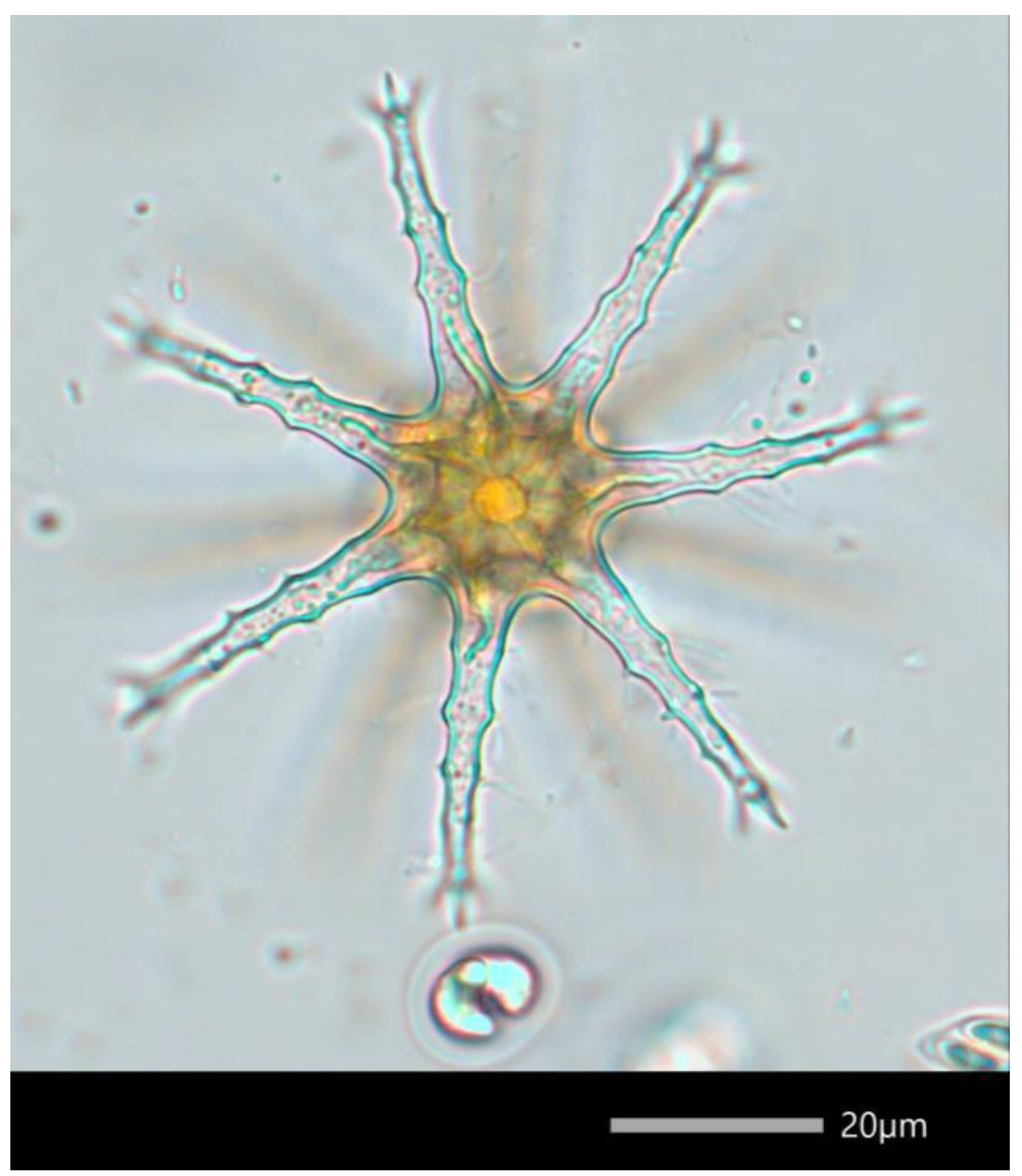


Staurastrum spiculosum A.M. Scott \& Grönblad, 1957

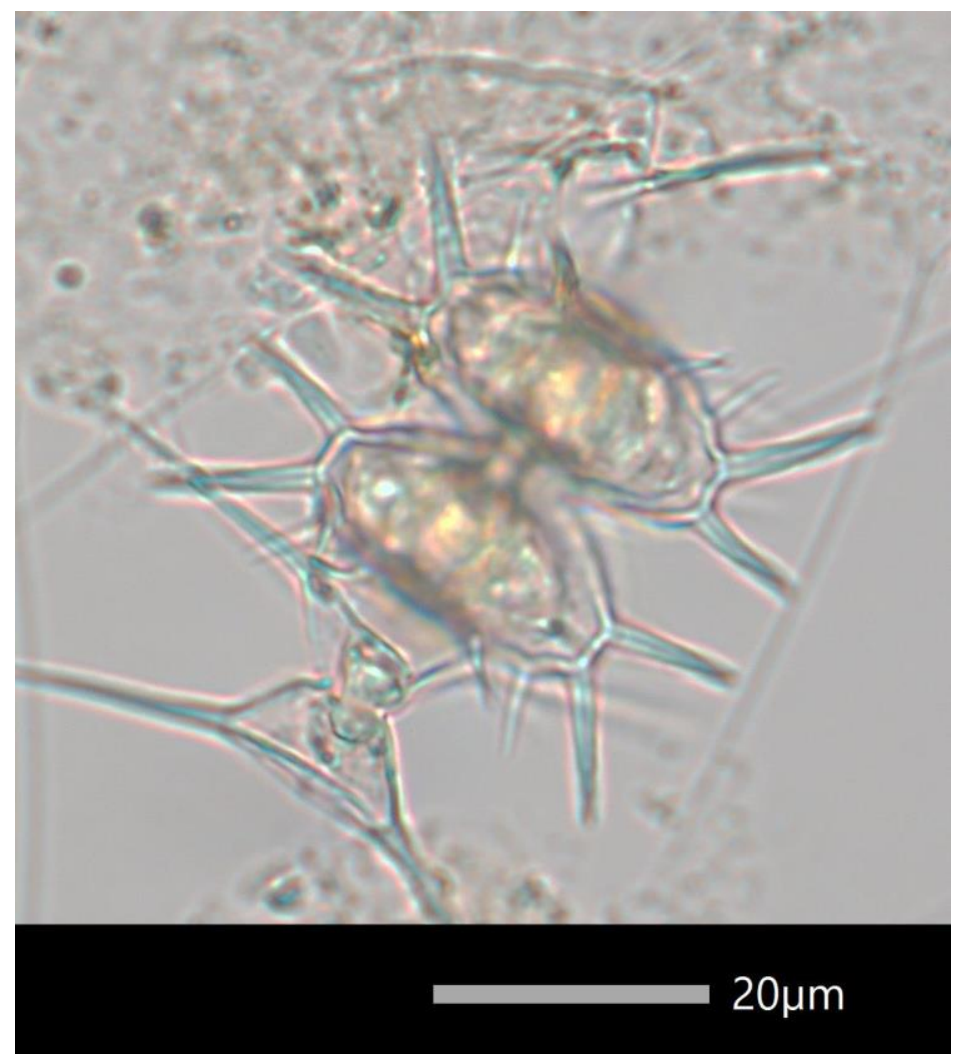

Staurastrum tenuissimum West \& G.S. West, 1895

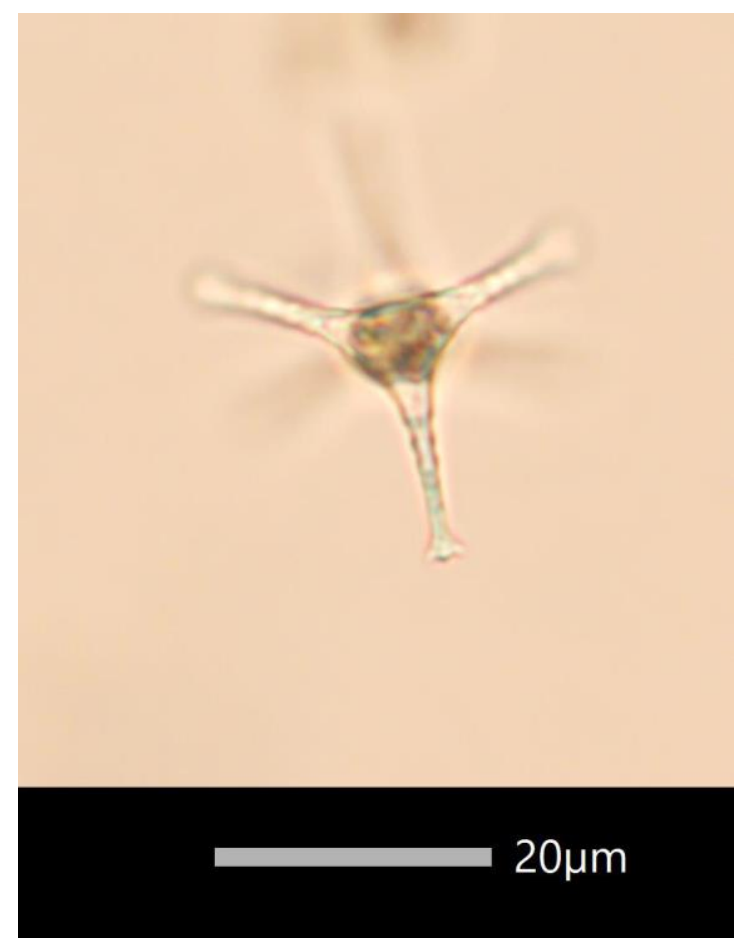


Staurastrum tetracerum Ralfs ex Ralfs, 1848

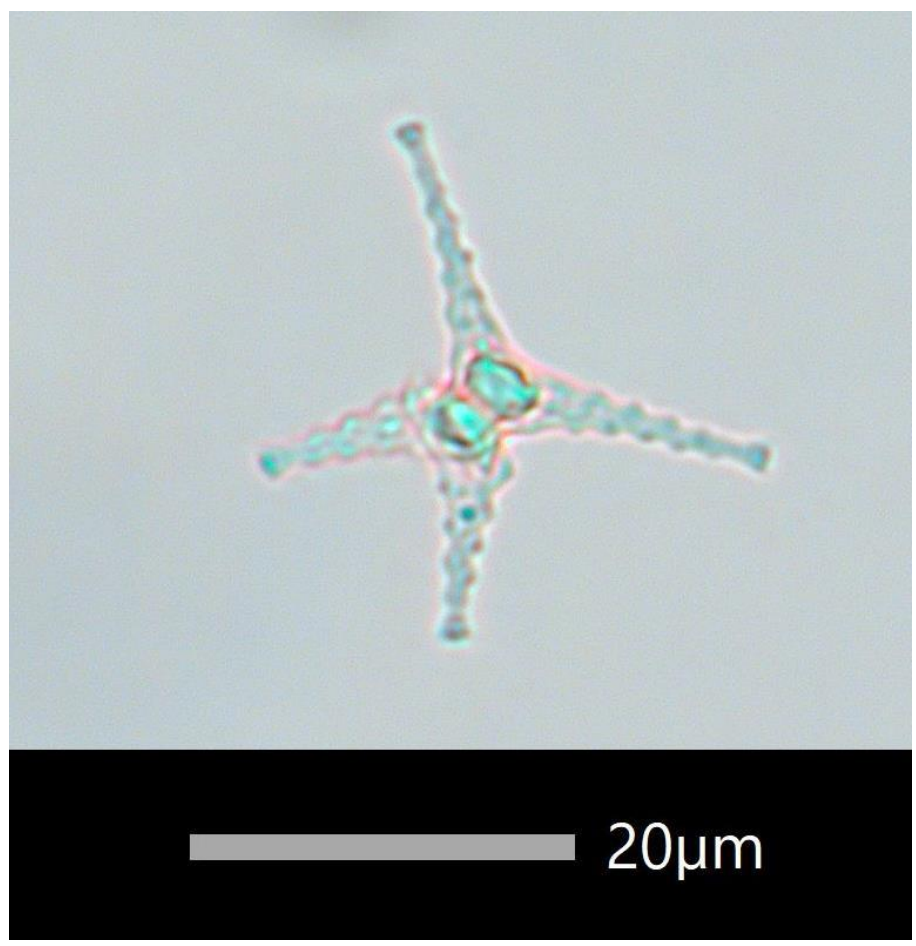

Staurastrum cf. turgescens v. sparsigranulatum A.M. Scott \& Grönblad, 1957

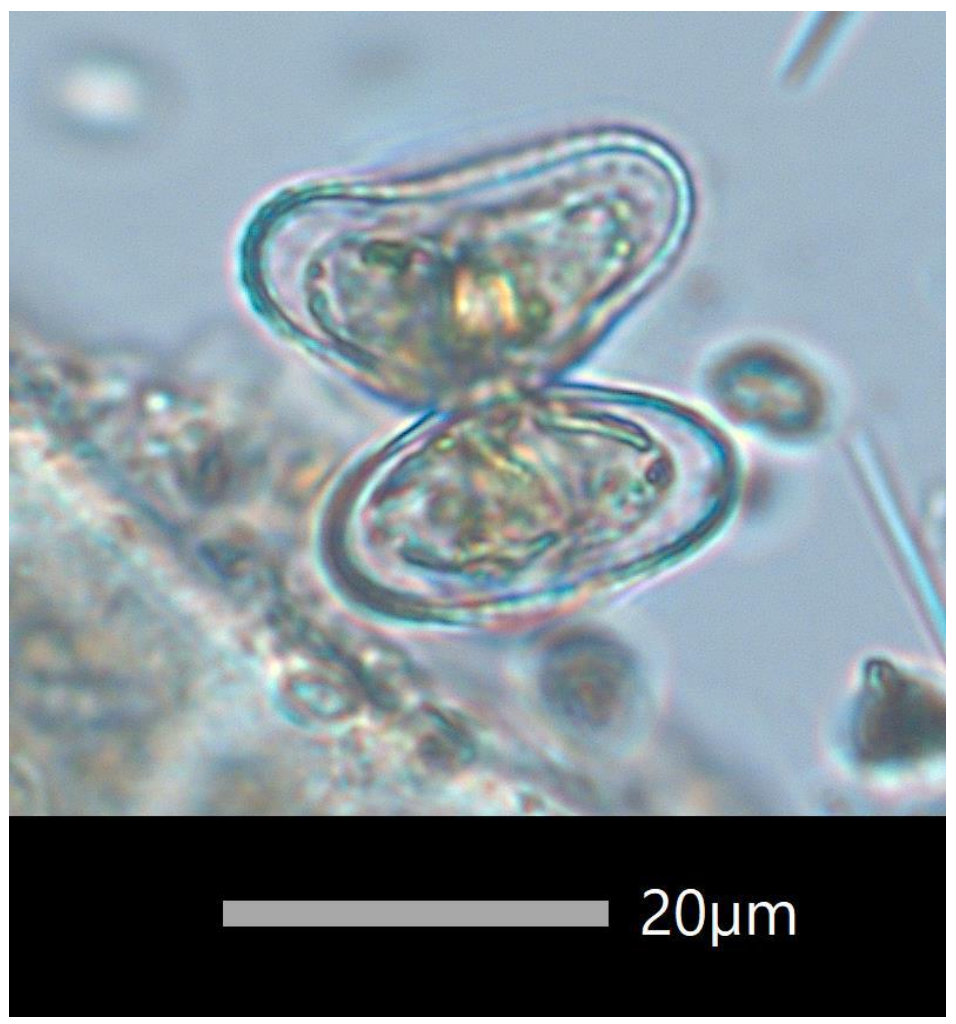


Staurodesmus connatus (P. Lundell) Thomasson, 1960

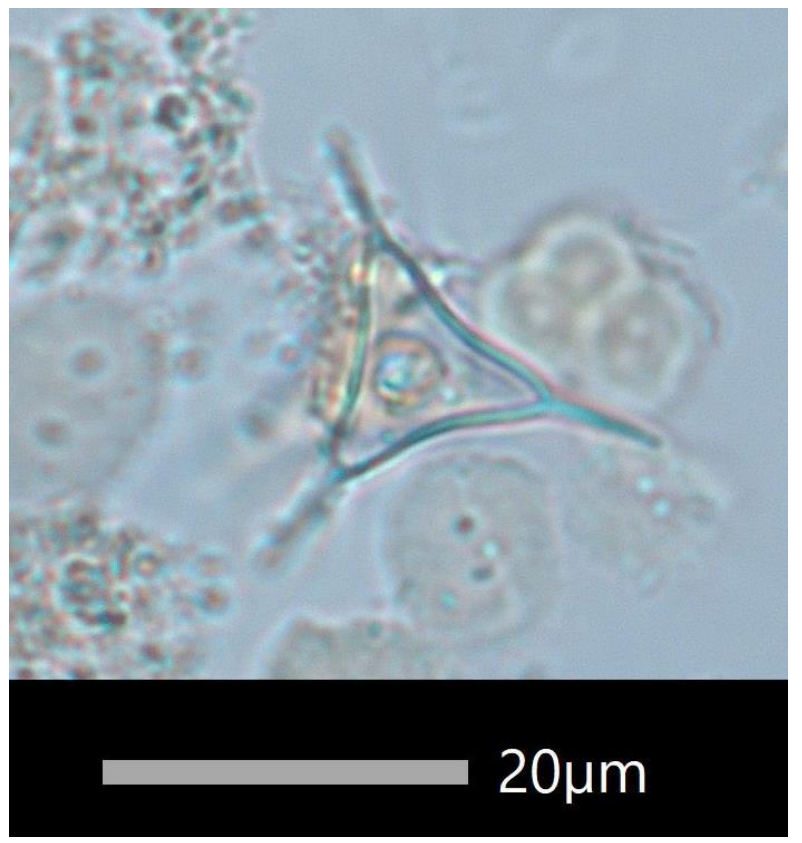

Staurodesmus extensus (O.F. Andersson) Teiling, 1948

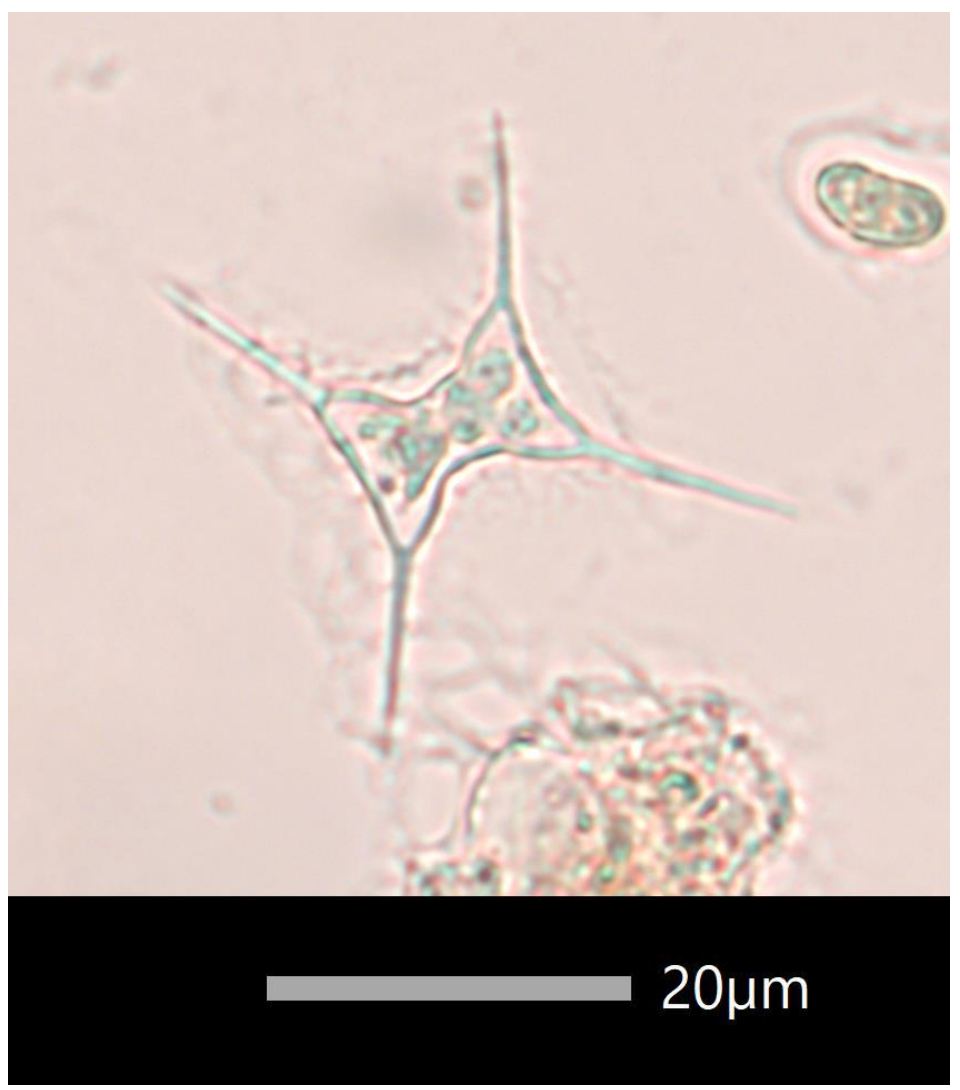


Staurodesmus incus v. indentatus (West \& G.S. West) Coesel, 2007

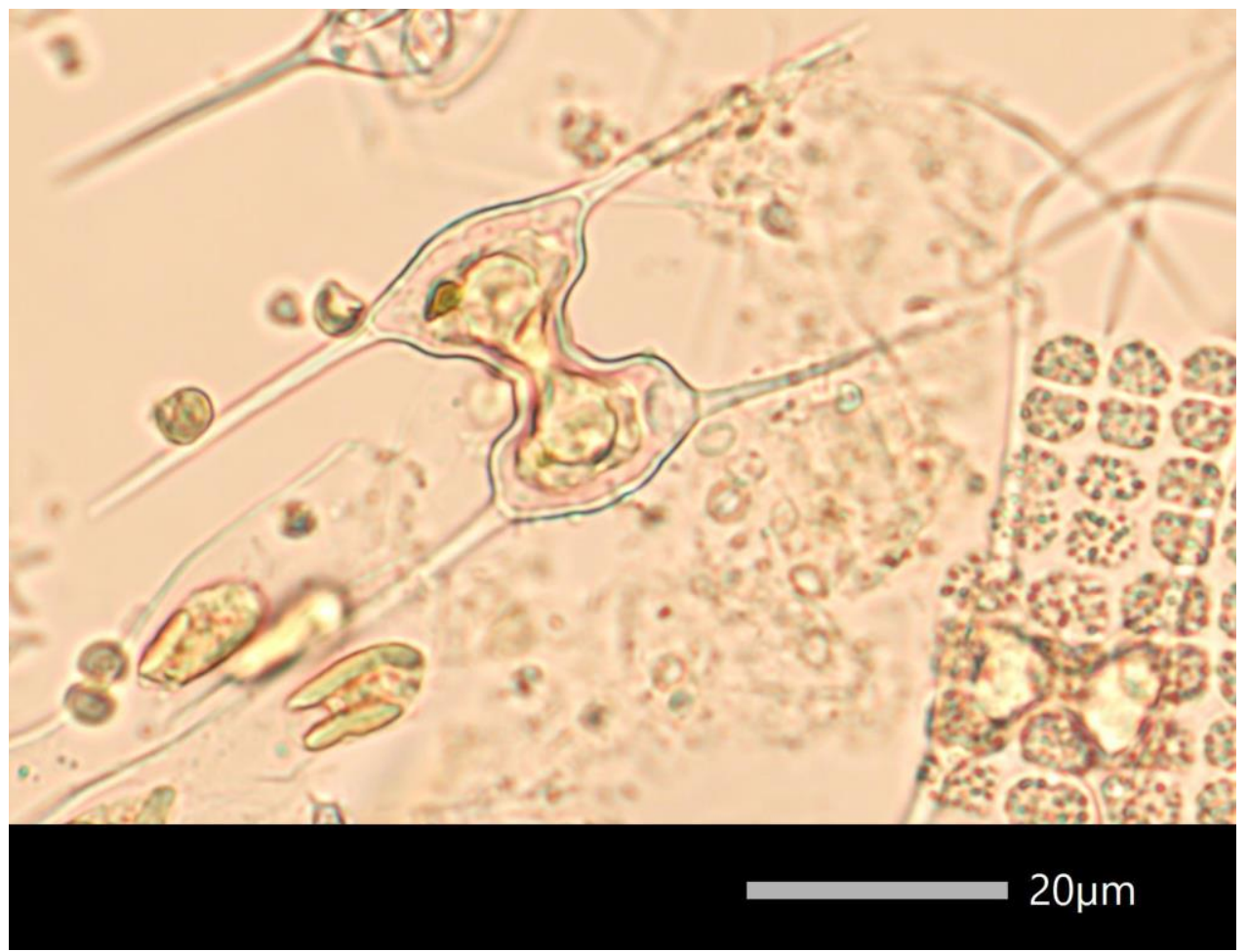

Staurdoesmus maximus v. divergens (Borge) Teiling, 1967

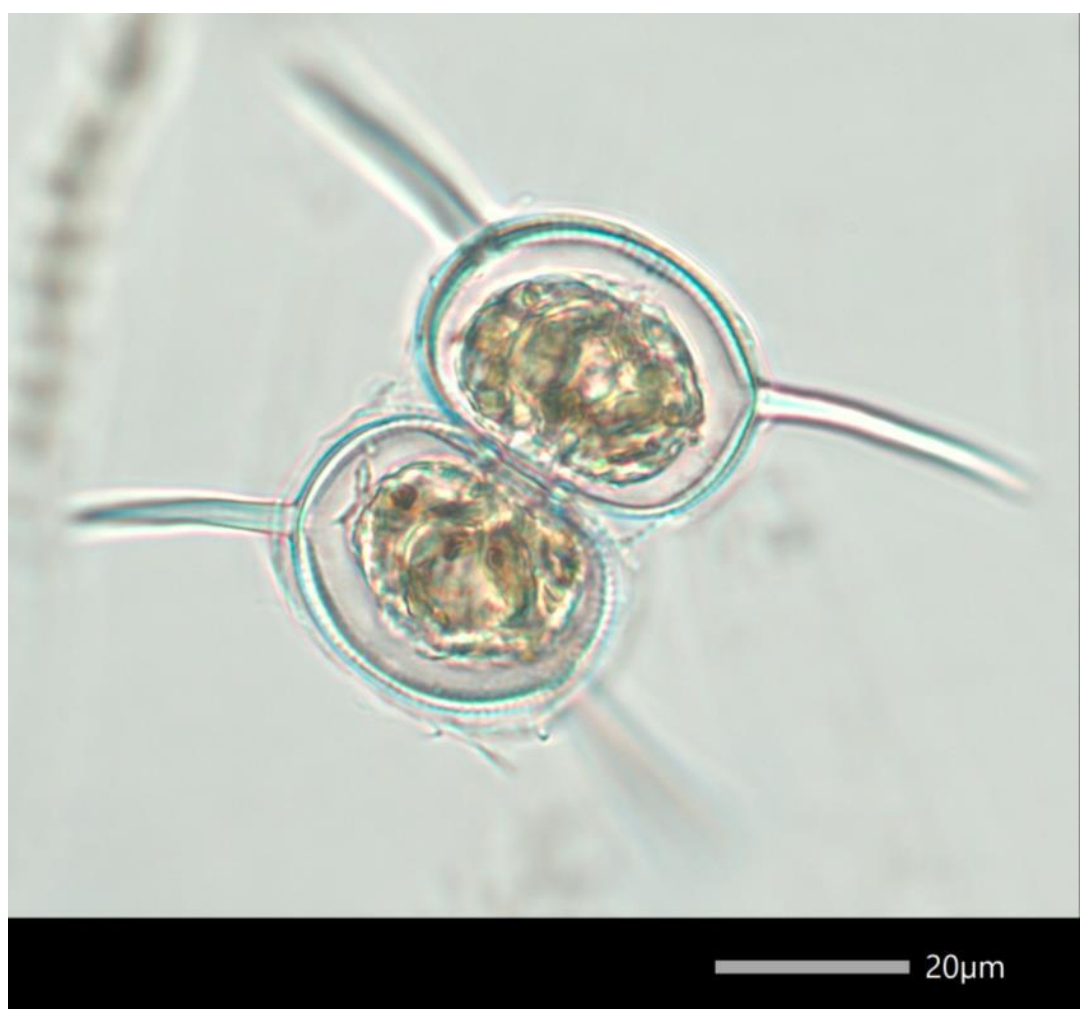


Staurodesmus octocornis (Ehrenberg ex Ralfs) Stastny, Skaloud, \& Neustupa, 2013

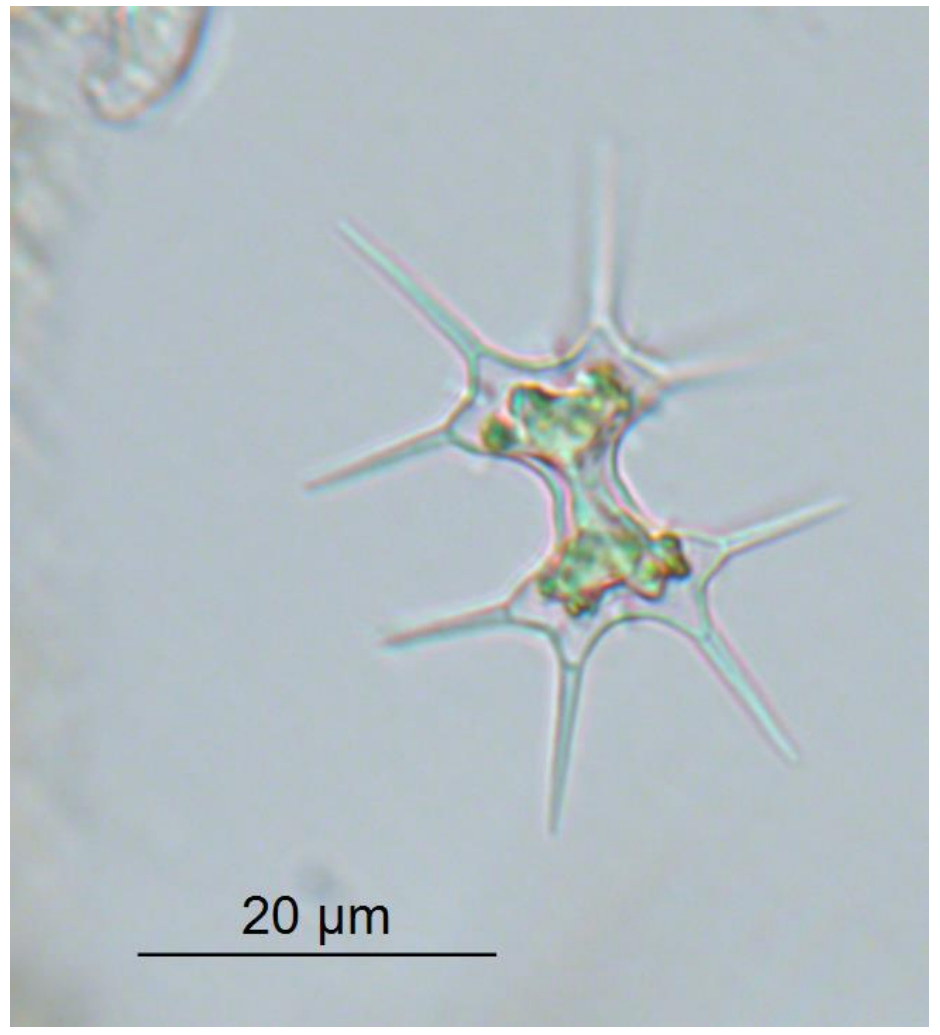


Staurodesmus triangularis v. inflatus (Lagerheim) Teiling, 1948
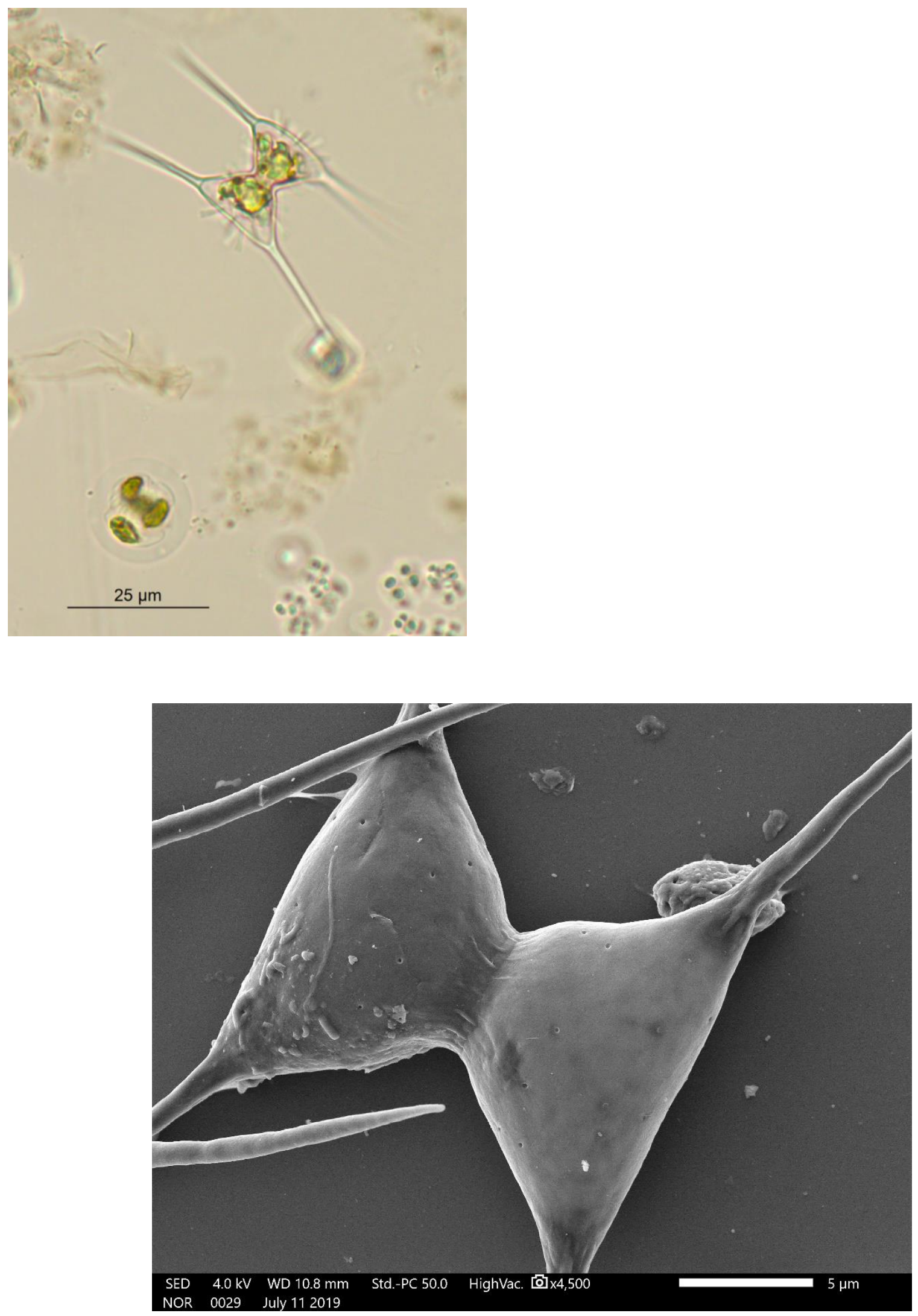
Xanthidium antilopaeum v. americanum A.M. Scott \& Grönblad, N.D.

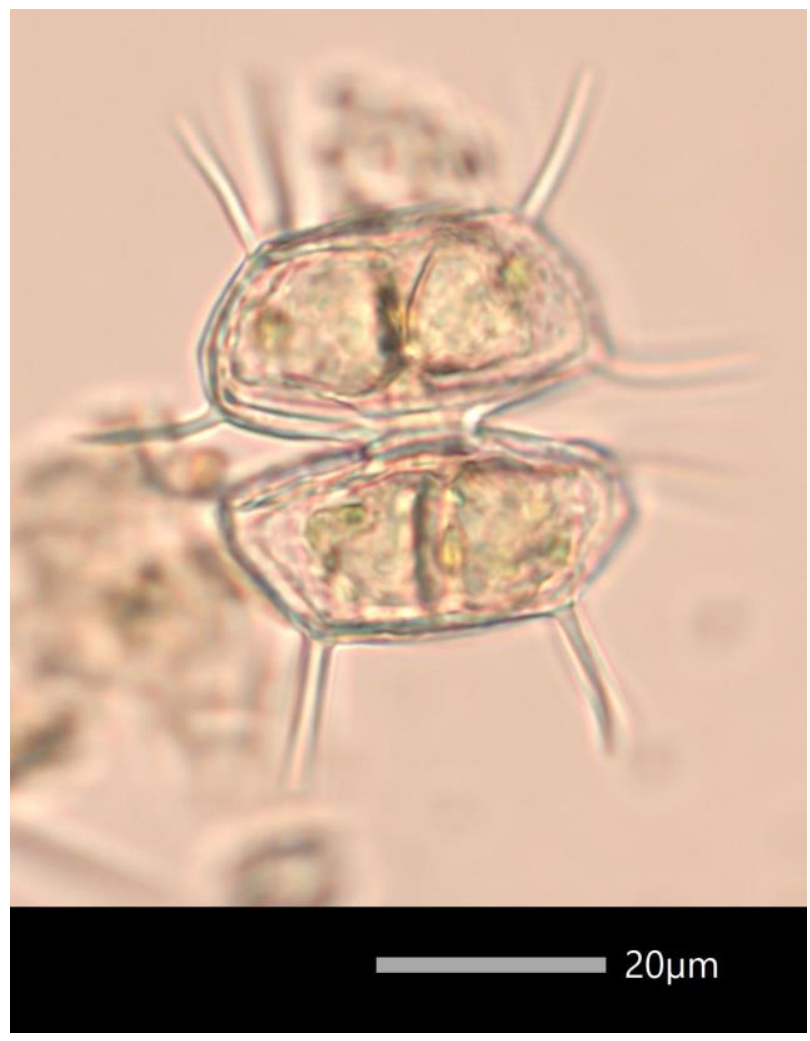

Xanthidium antilopaeum f. javanicum (Nordstedt) Coesel, 2007

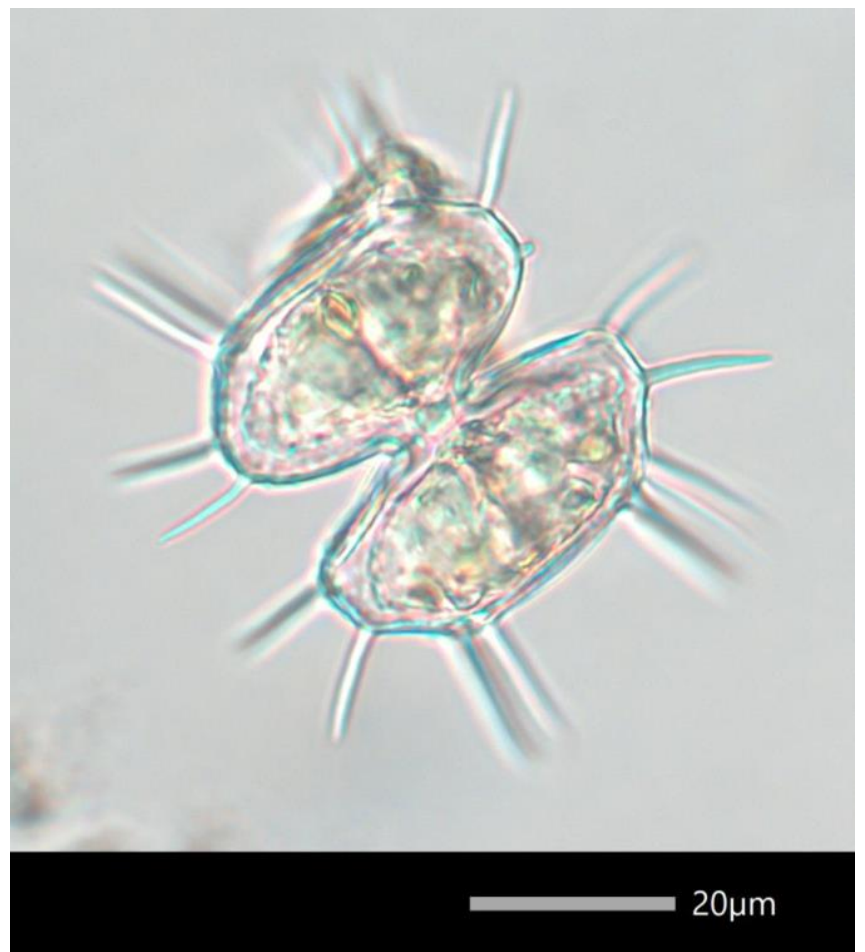


Xanthidium armatum v. cervicorne West \& G.S. West, 1898

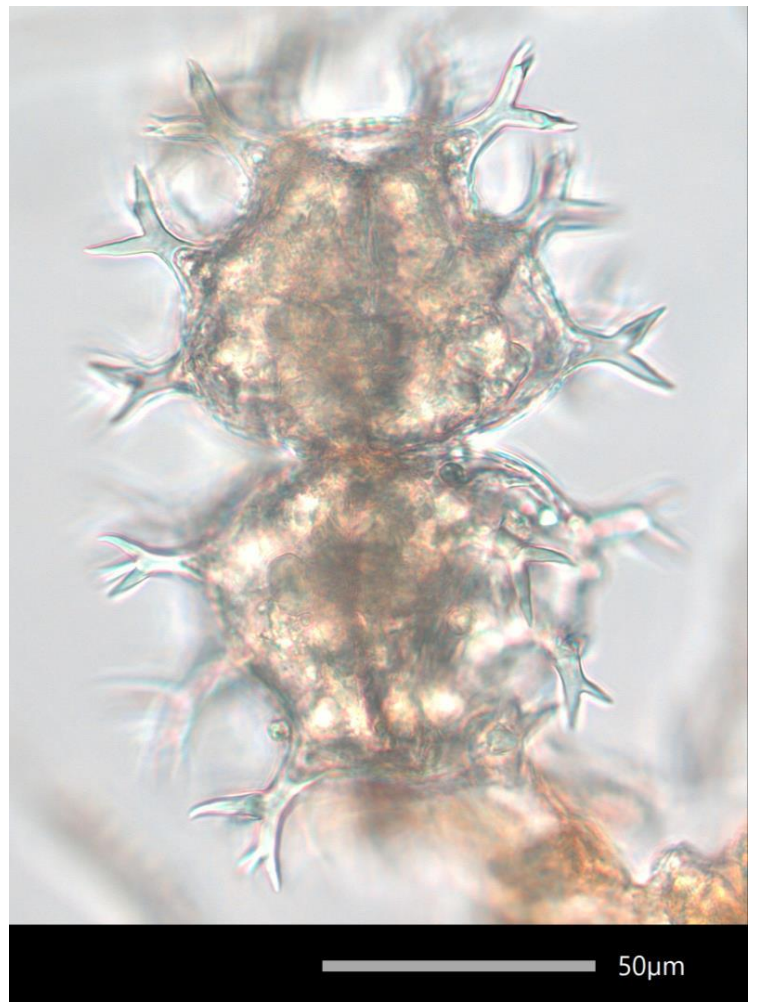

Xanthidium cristatum v. scrobiculatum f. papillatum A.M. Scott \& Grönblad, N.D.

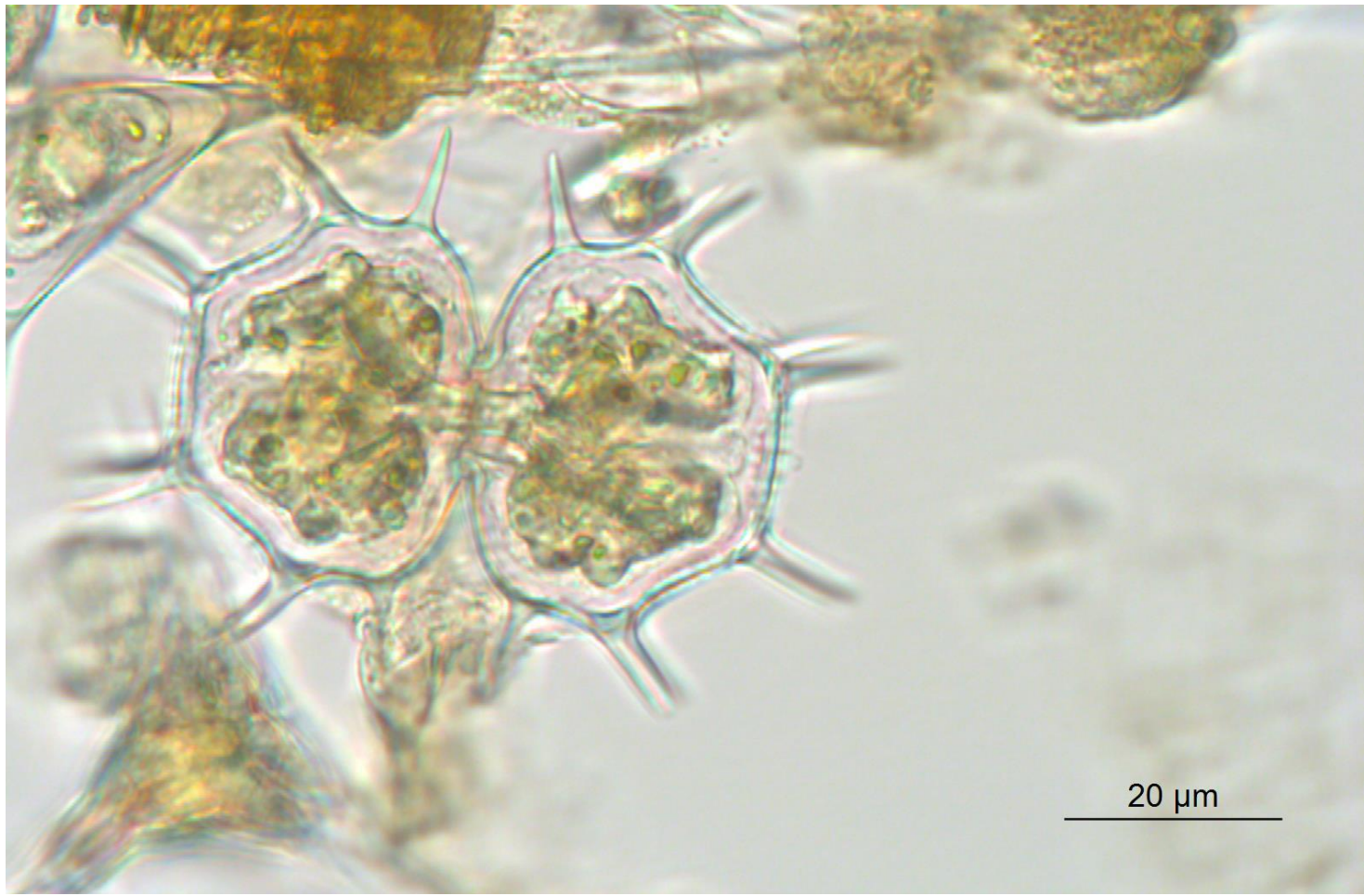


Unknown desmid filament

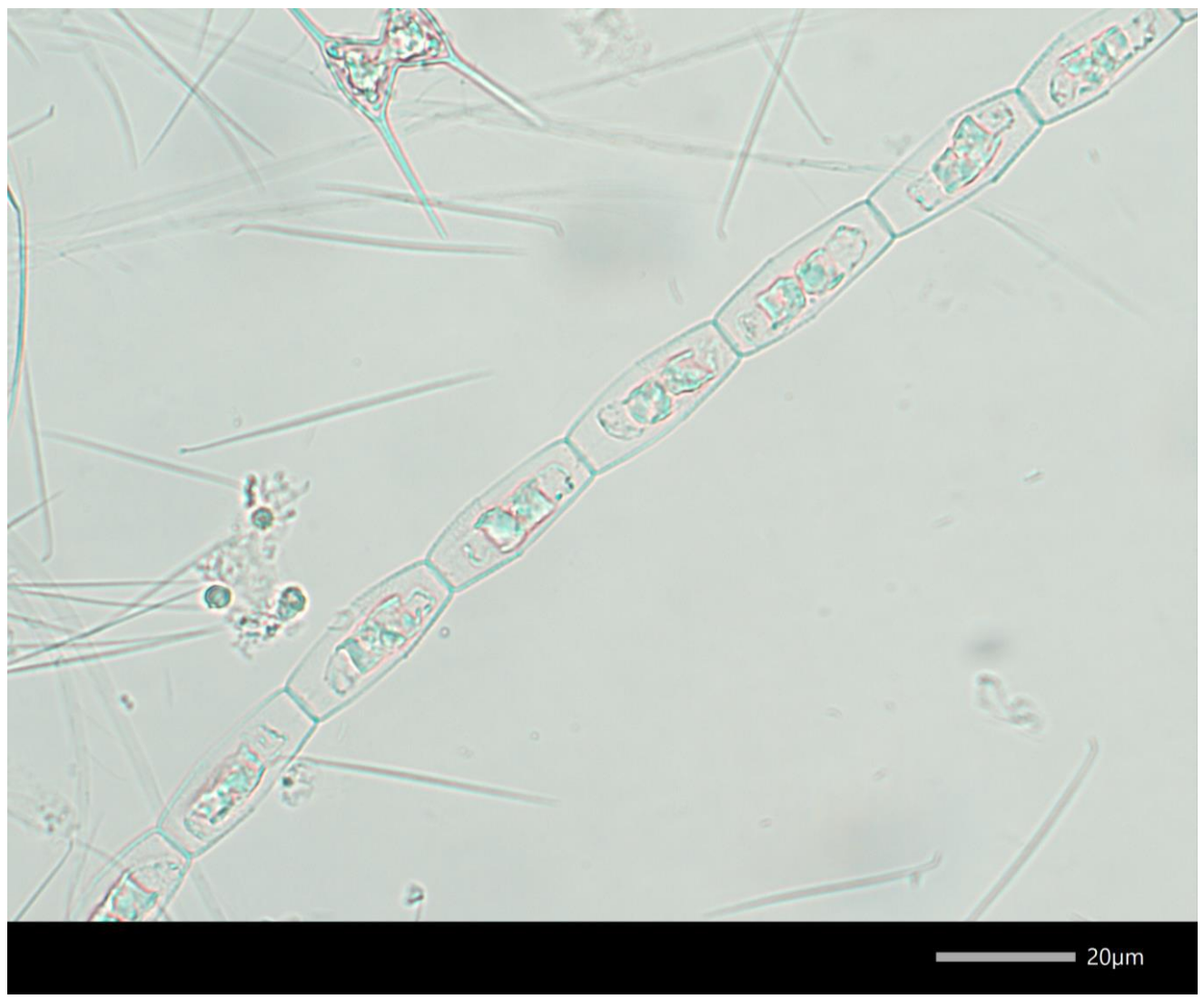

Unknown desmid

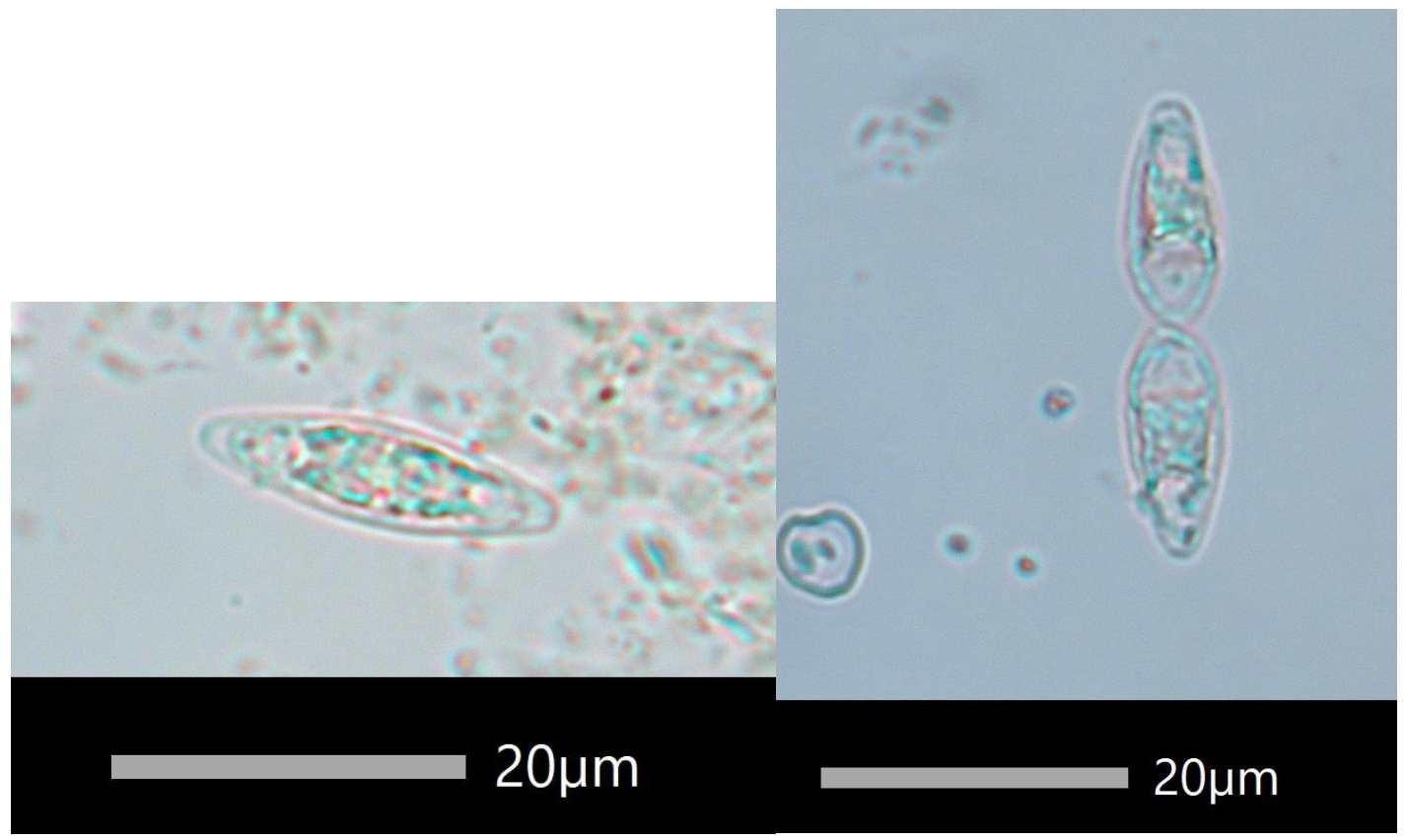




\section{Chlorophyta}

Ankistrodesmus cf. bernardii Komárek, 1983

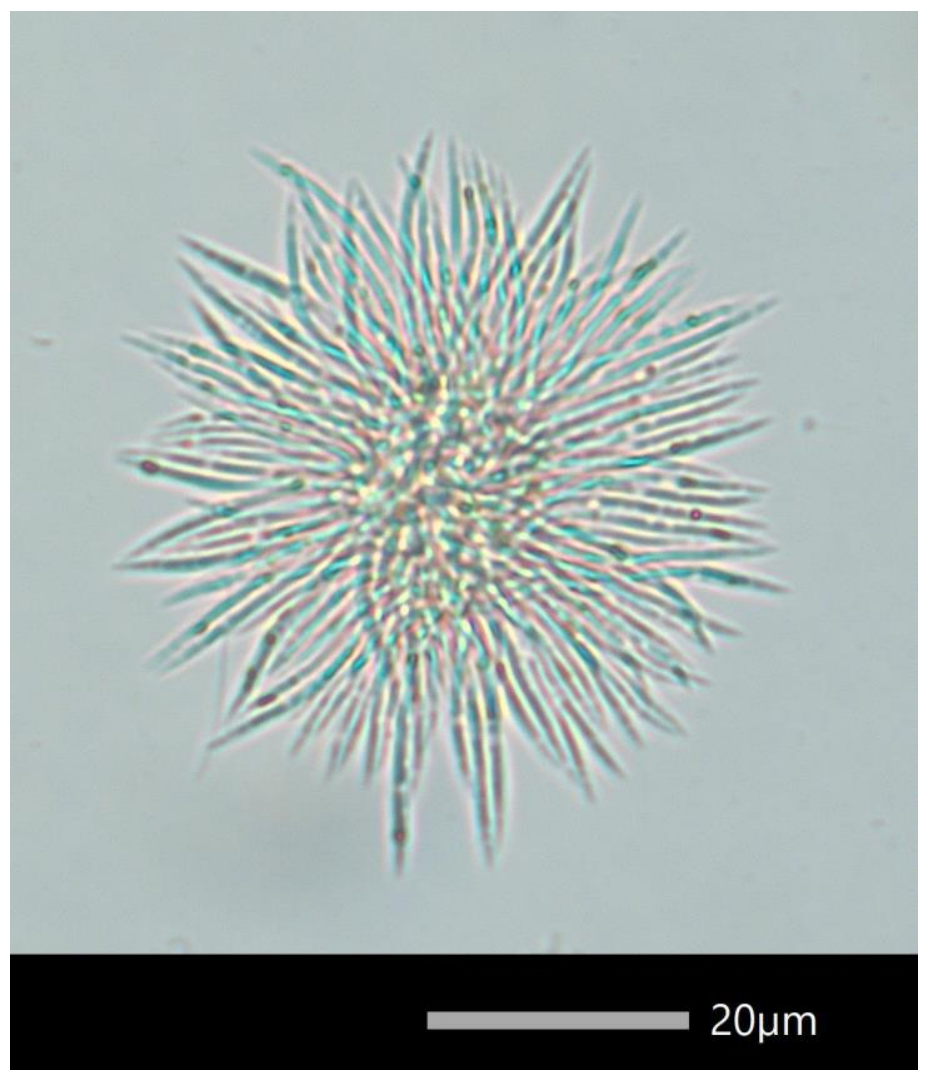

Asterococcus sp. cf. Scherffel, 1908
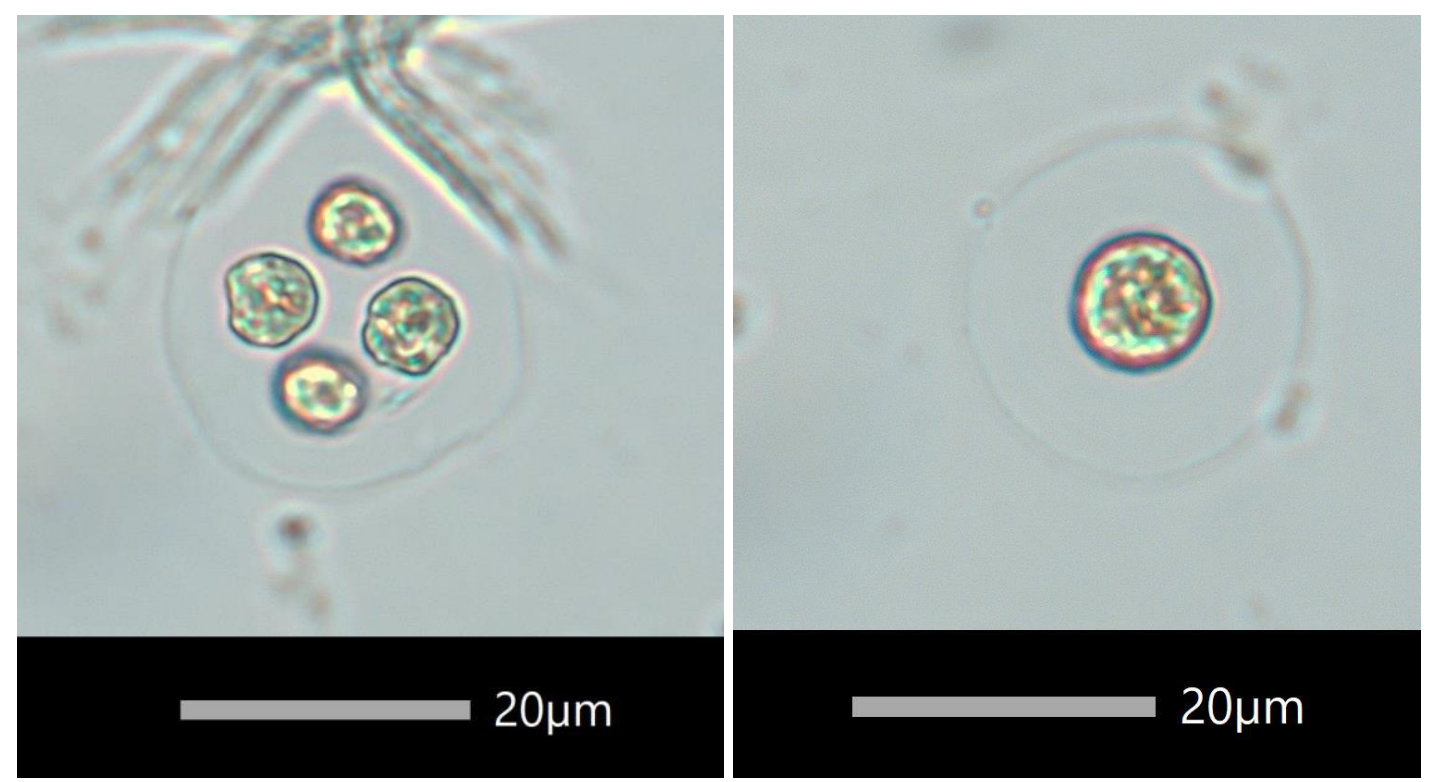
Botryococcus sp. Kützing, 1849

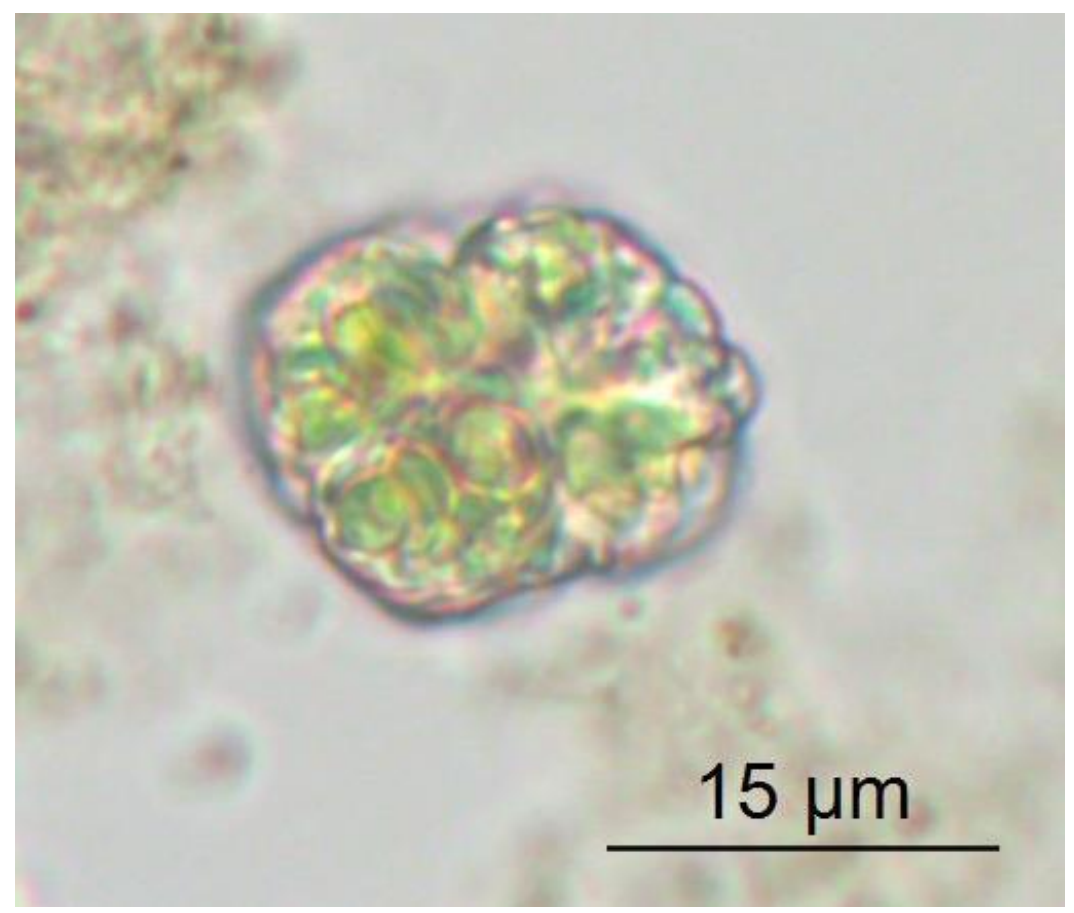


Botryococcus braunii Kützing, 1849
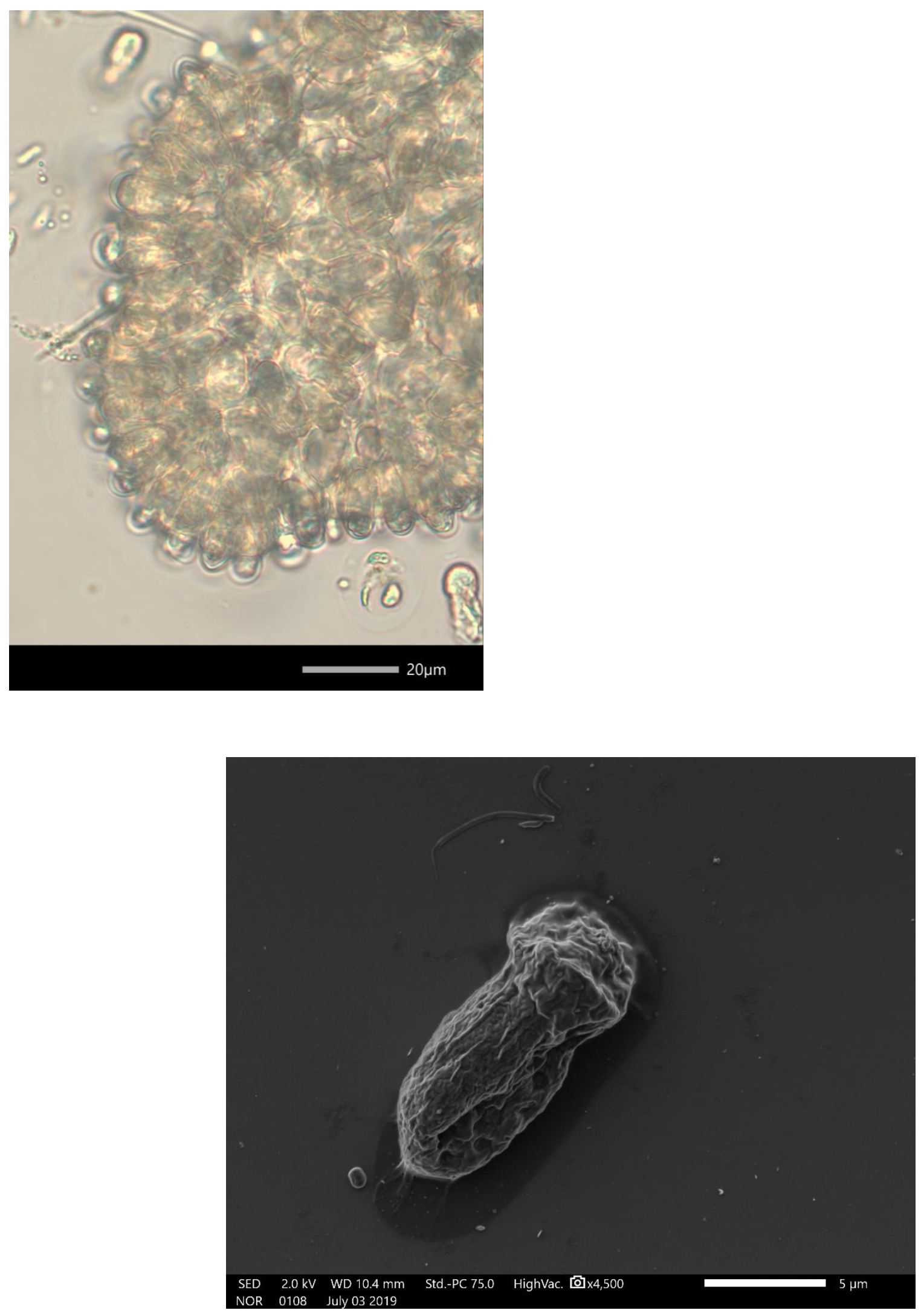
Chlamydomonas spp. Ehrenberg, 1833
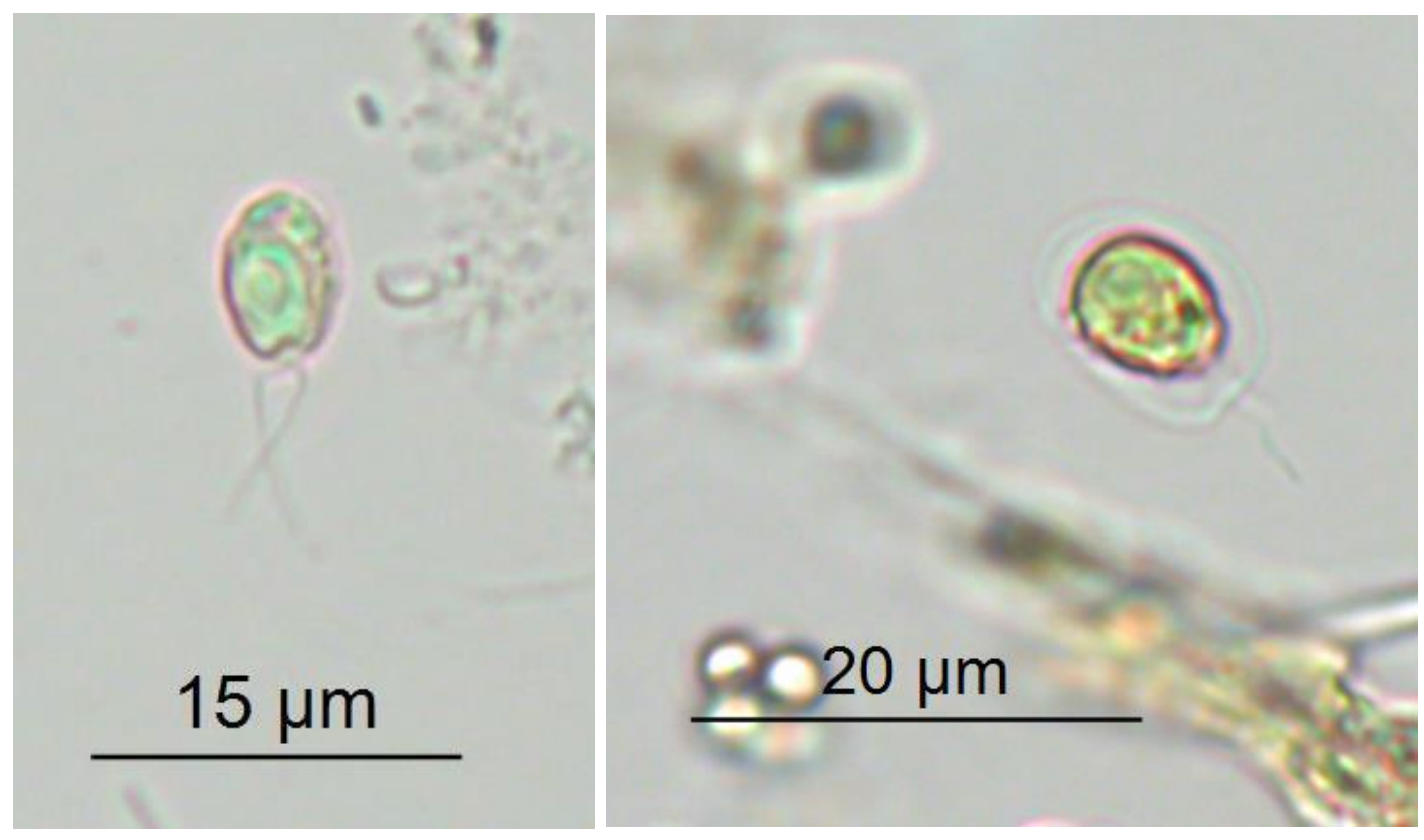

Chlamydomonas fusus Ettl, 1965

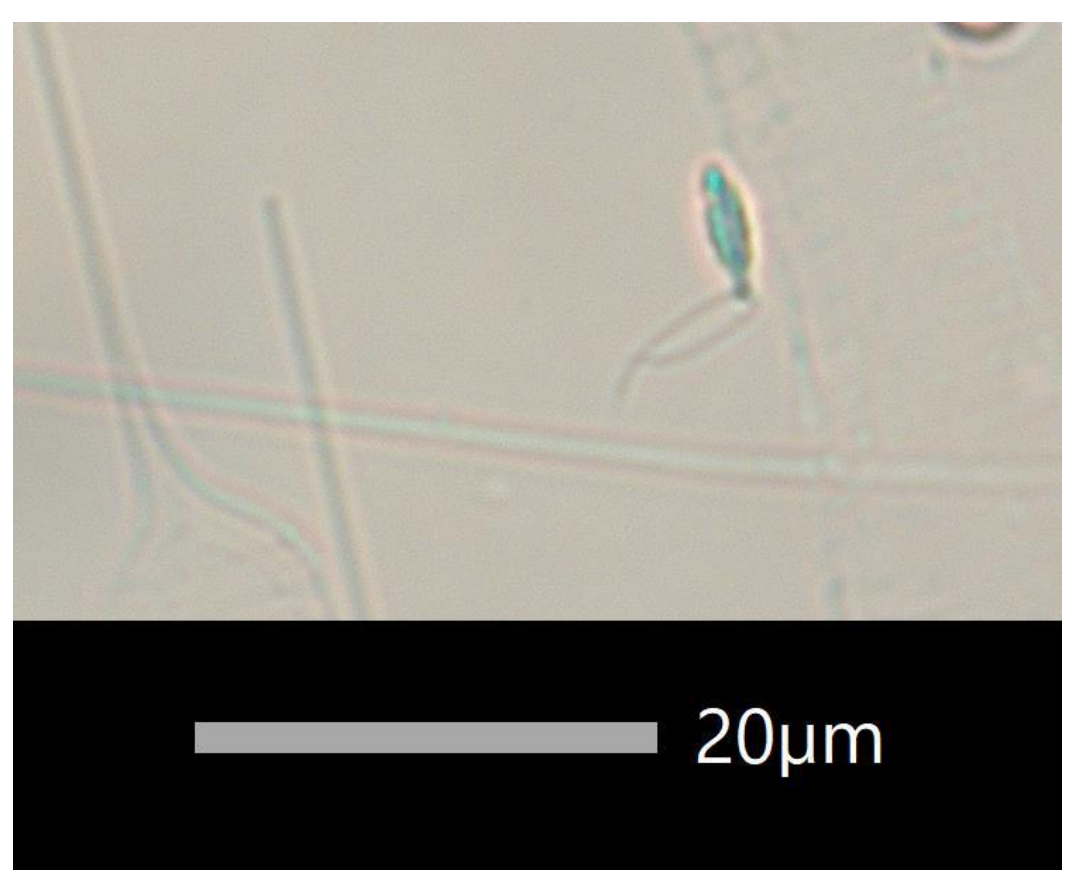


Closteriopsis sp. Lemmerman, 1899

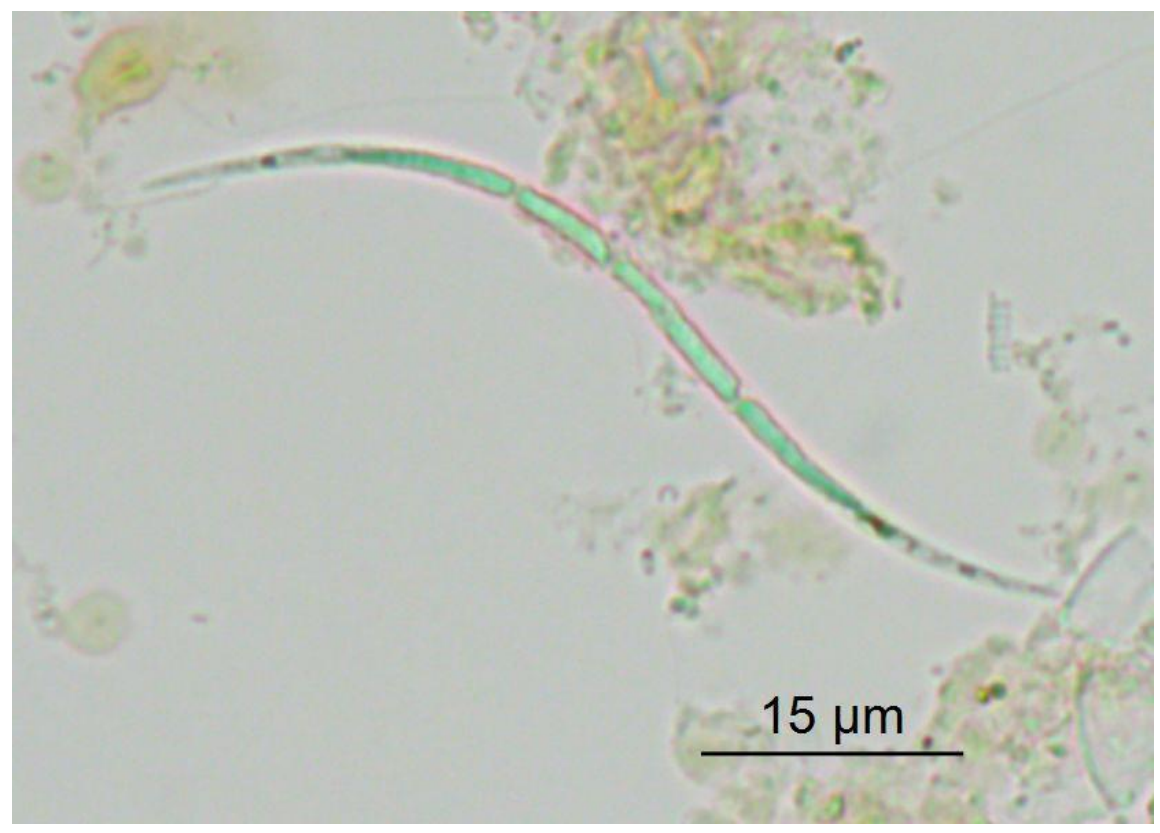

Coelastrum cruciatum Schmidle, 1900

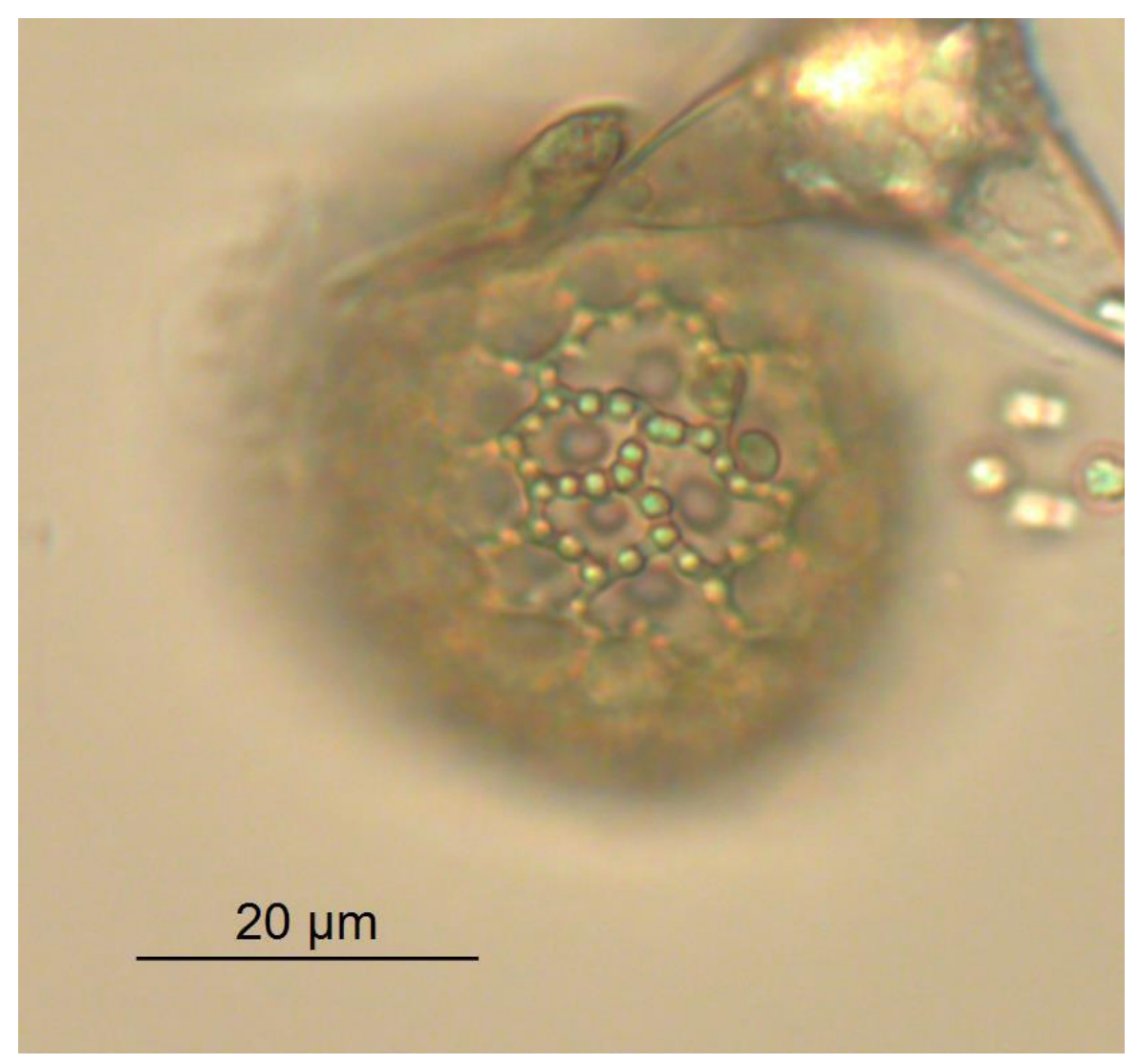


Coelastrum pulchrum v. cruciatum (Kammerer) Komárek, 1983

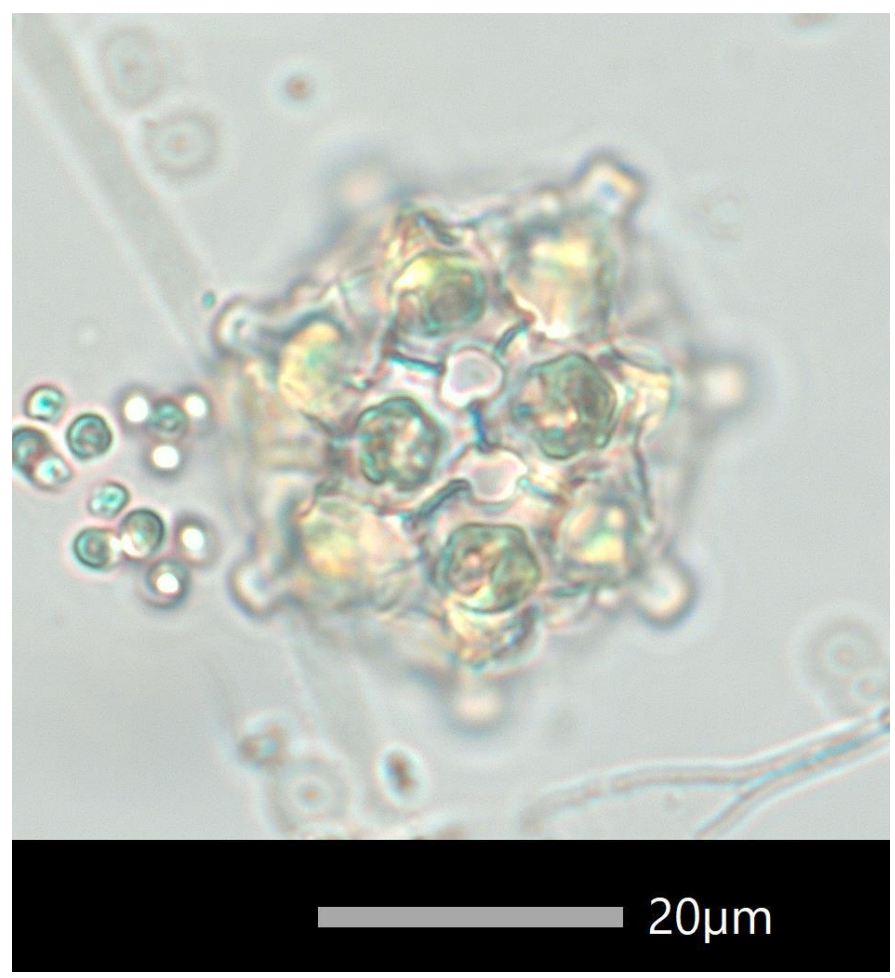

Cylindrocapsa cf. geminella Wolle, 1887

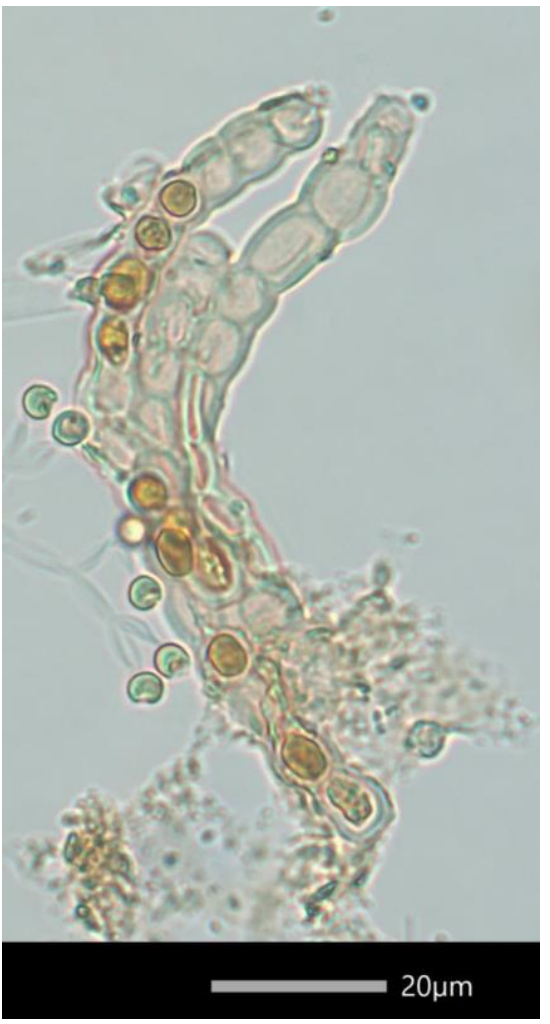


Eudorina spp. Ehrenberg, 1832

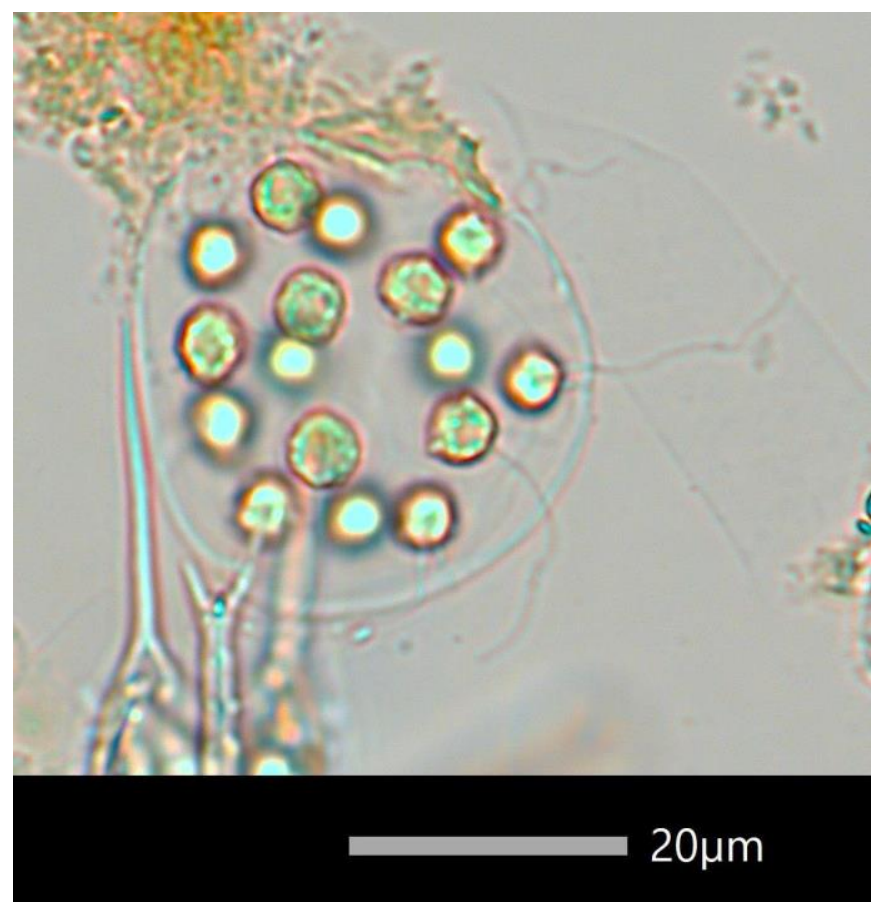

Eudorina elegans Ehrenberg, 1832

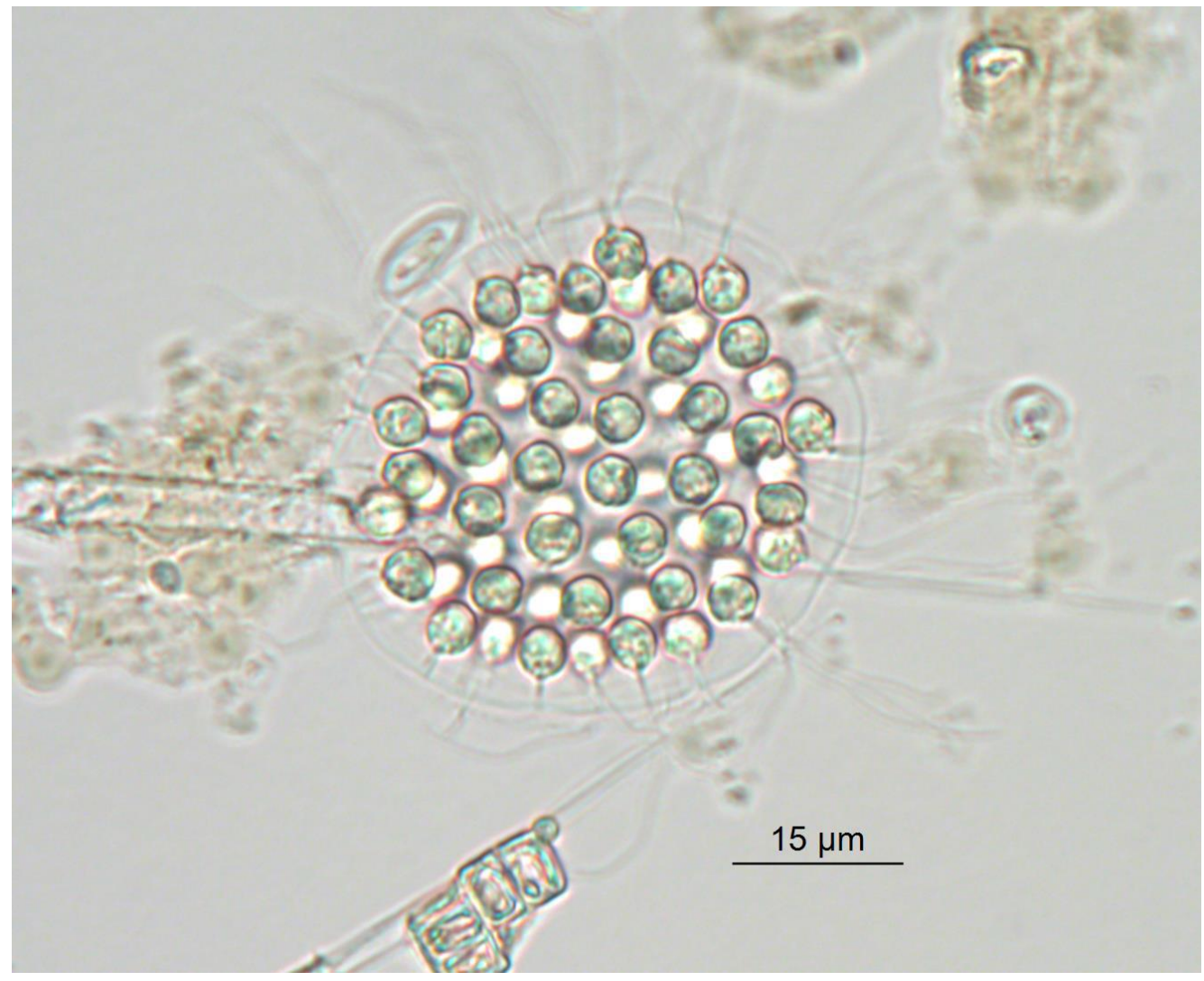


Golenkinia sp. cf. Chodat, 1894

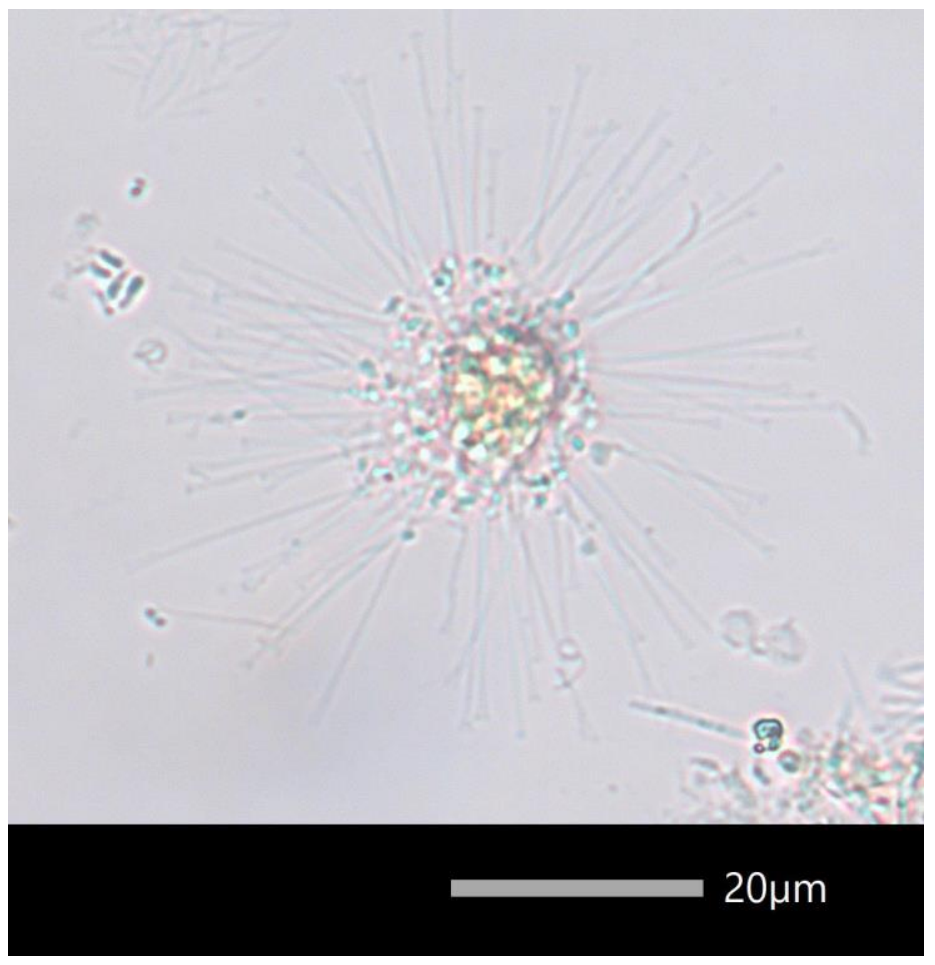

Mucidosphaerium sphagnale (H.C. Wood) C. Bock, Proschold \& Krienitz, 2011

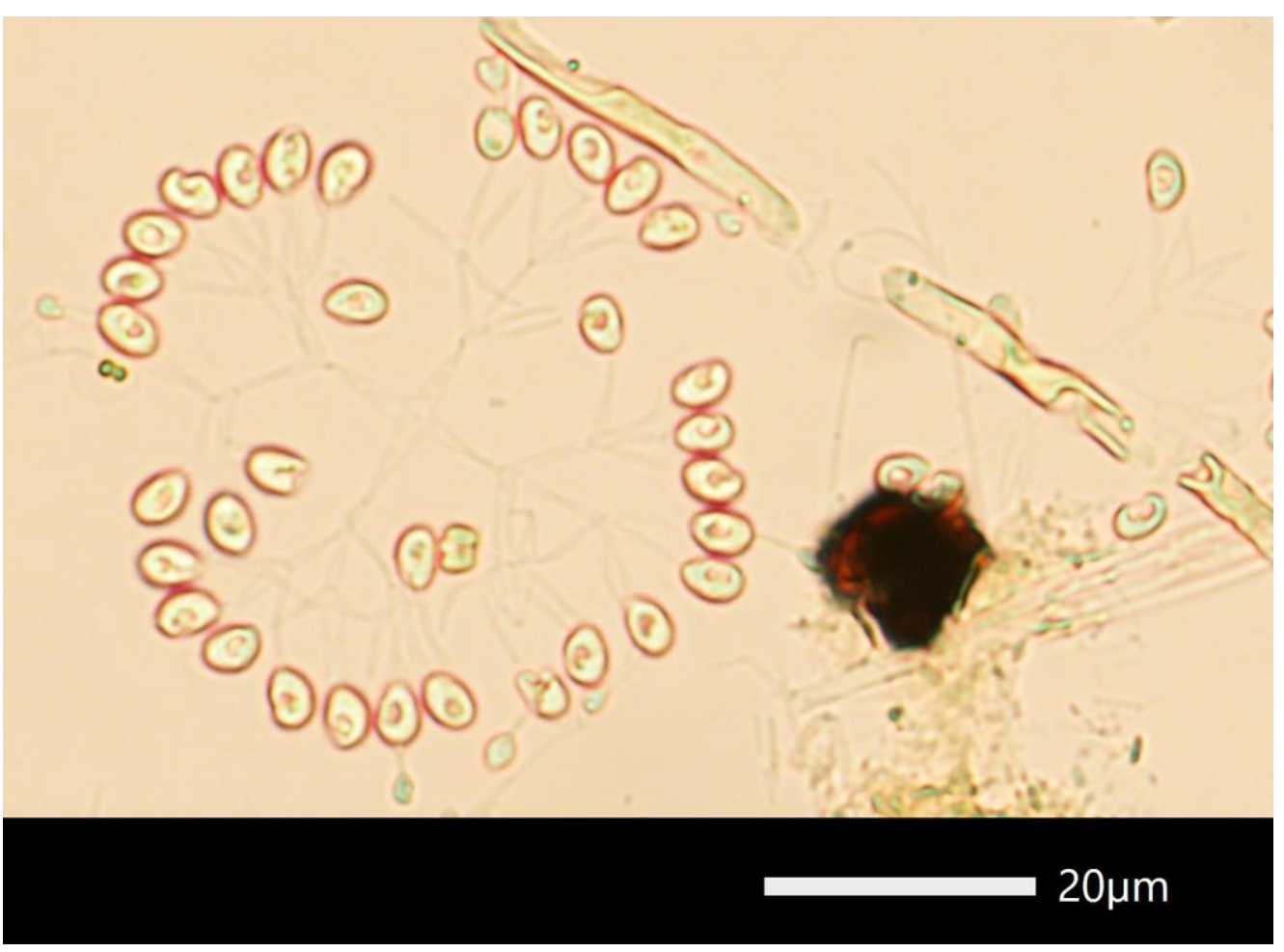


Mucidosphaerium cf. pulchellum (H.C. Wood) C. Bock, Proschold \& Krienitz, 2011

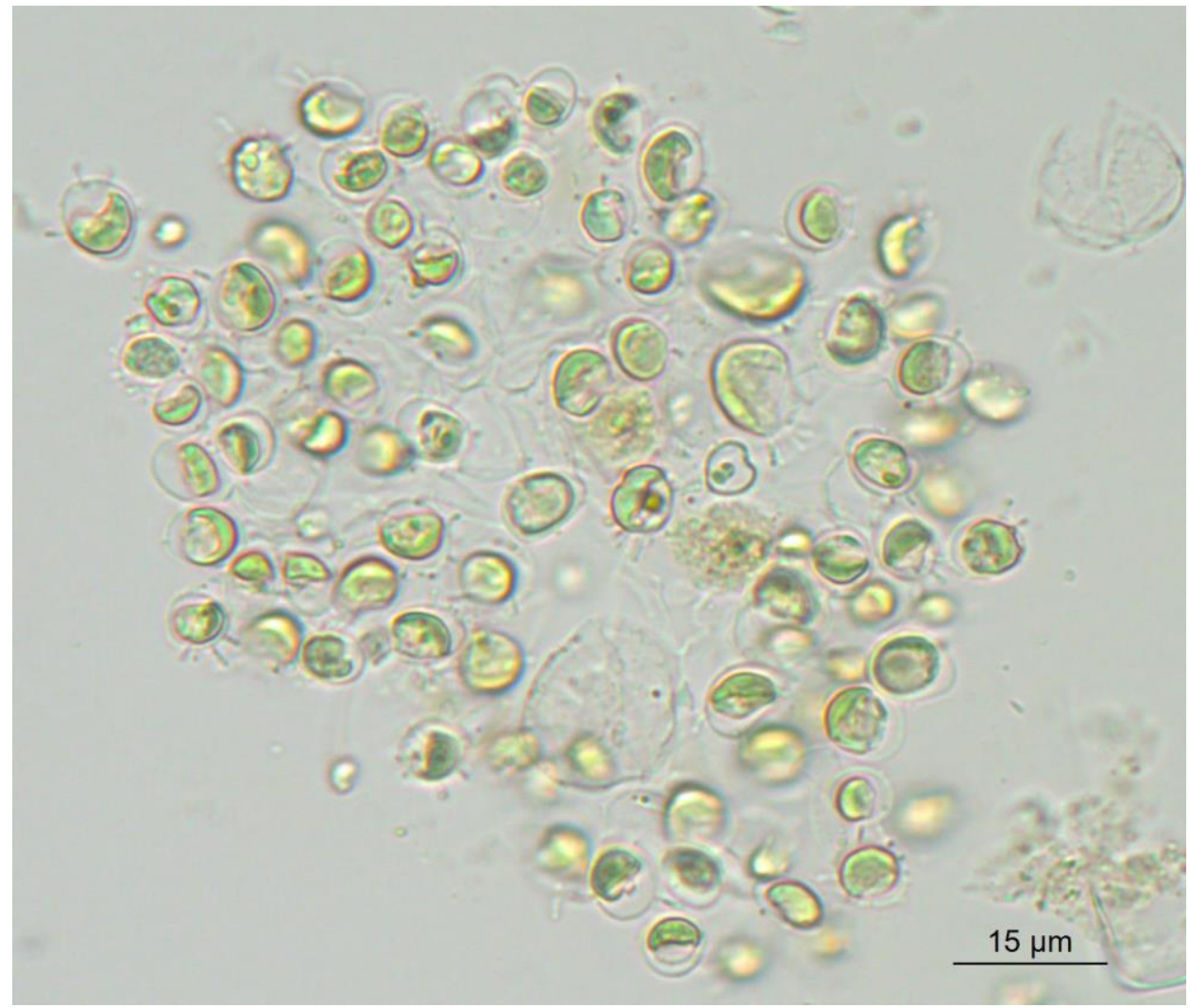

Nephrocytium cf. lunatum West, 1892

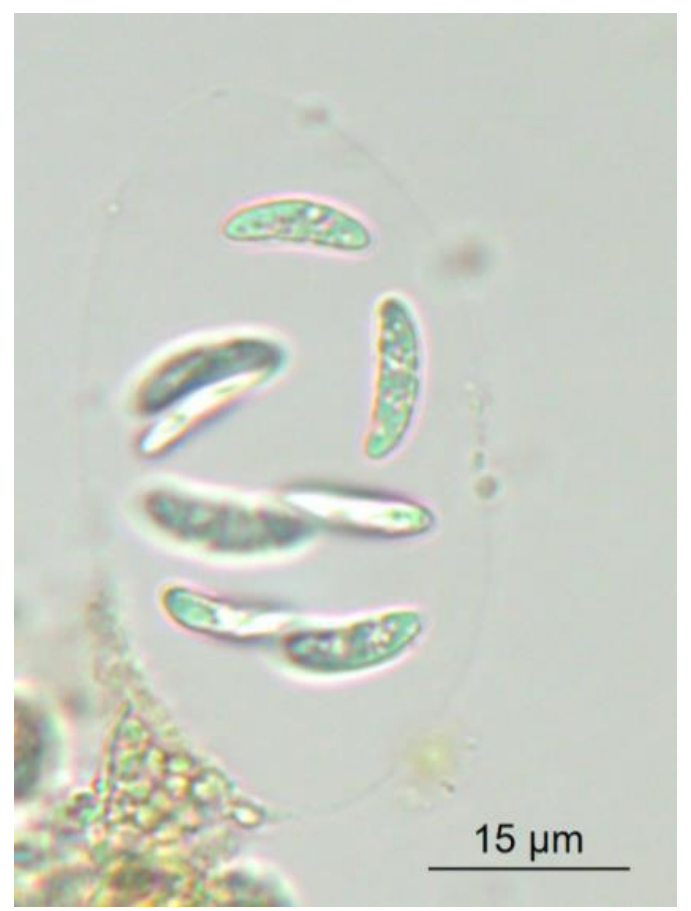


Oedogonium spp. Link ex Hirn, 1900

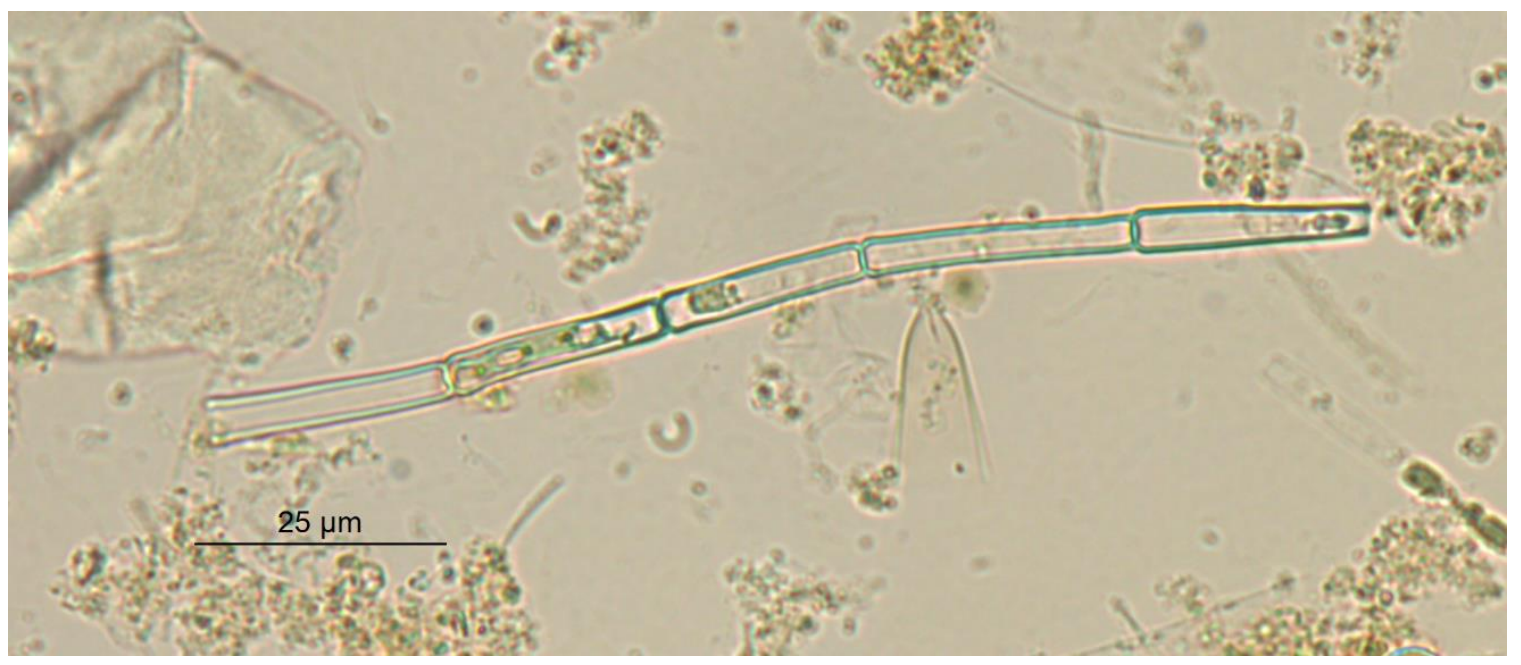

Oocystis submarina Lagerheim, 1886

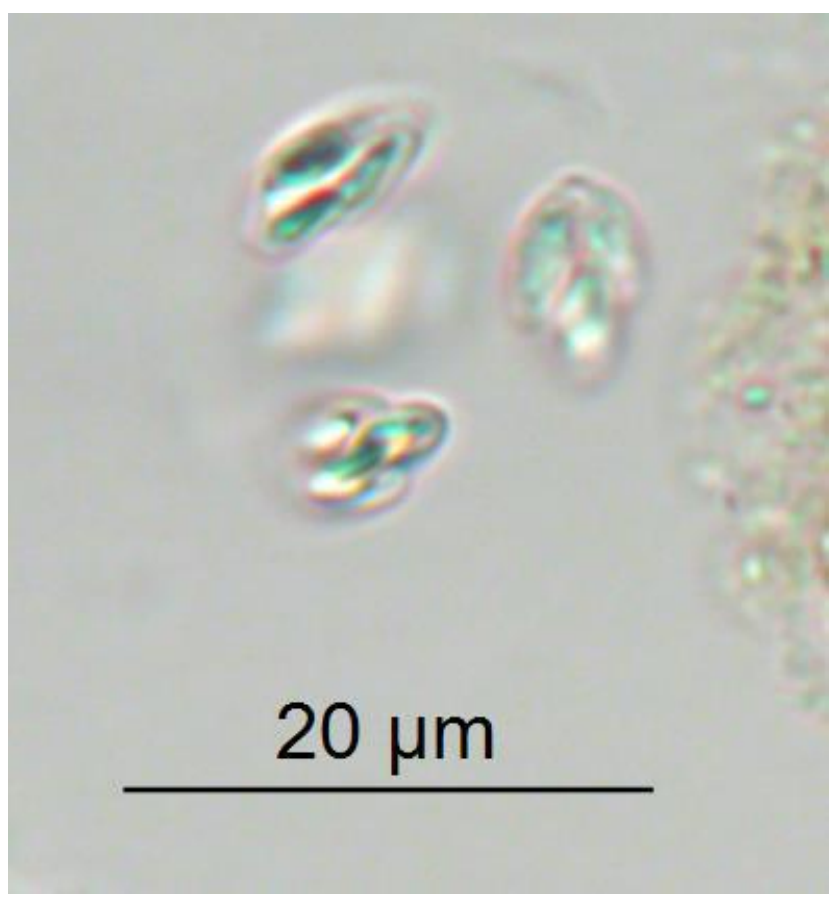


Oocystis sp. LG Nägeli ex A. Braun, 1855

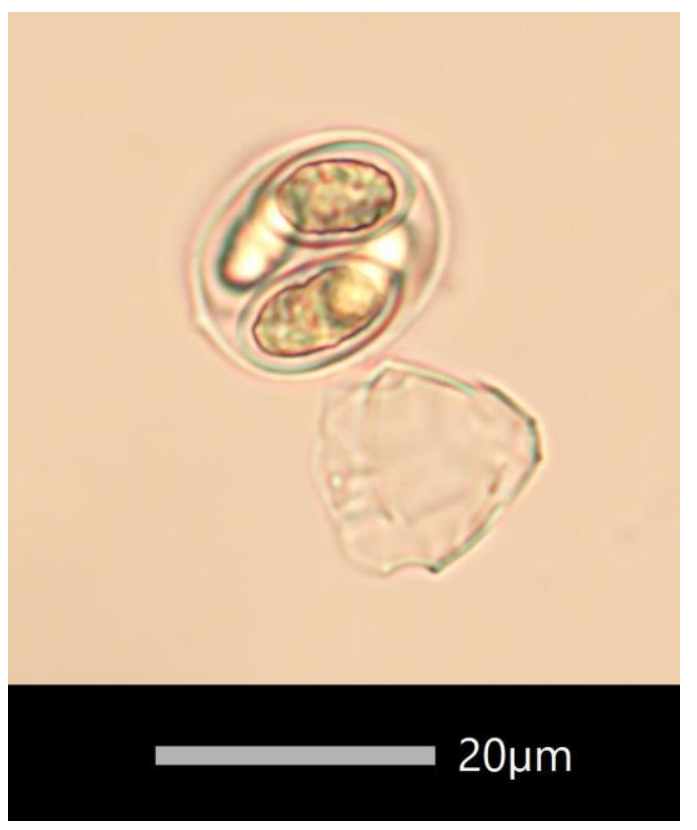

Oocystis sp. Nägeli ex A. Braun, 1855
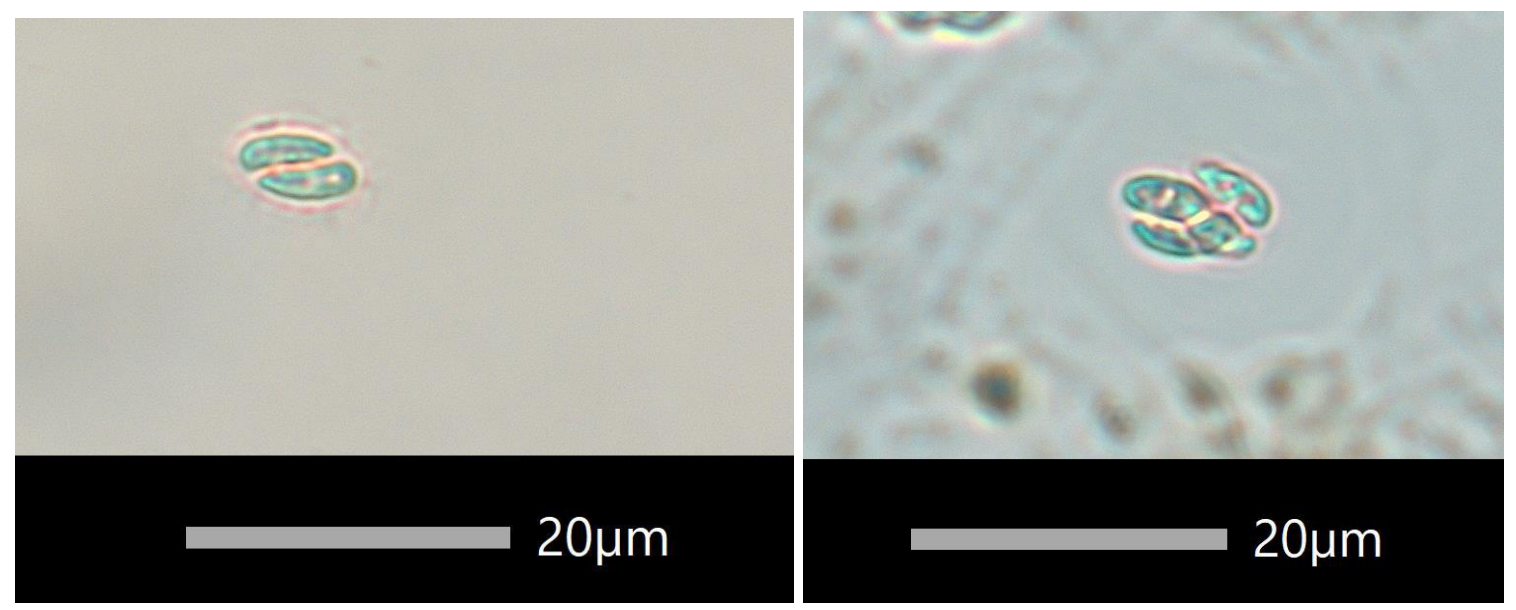
Pedinomonas sp. Korshikov, 1923

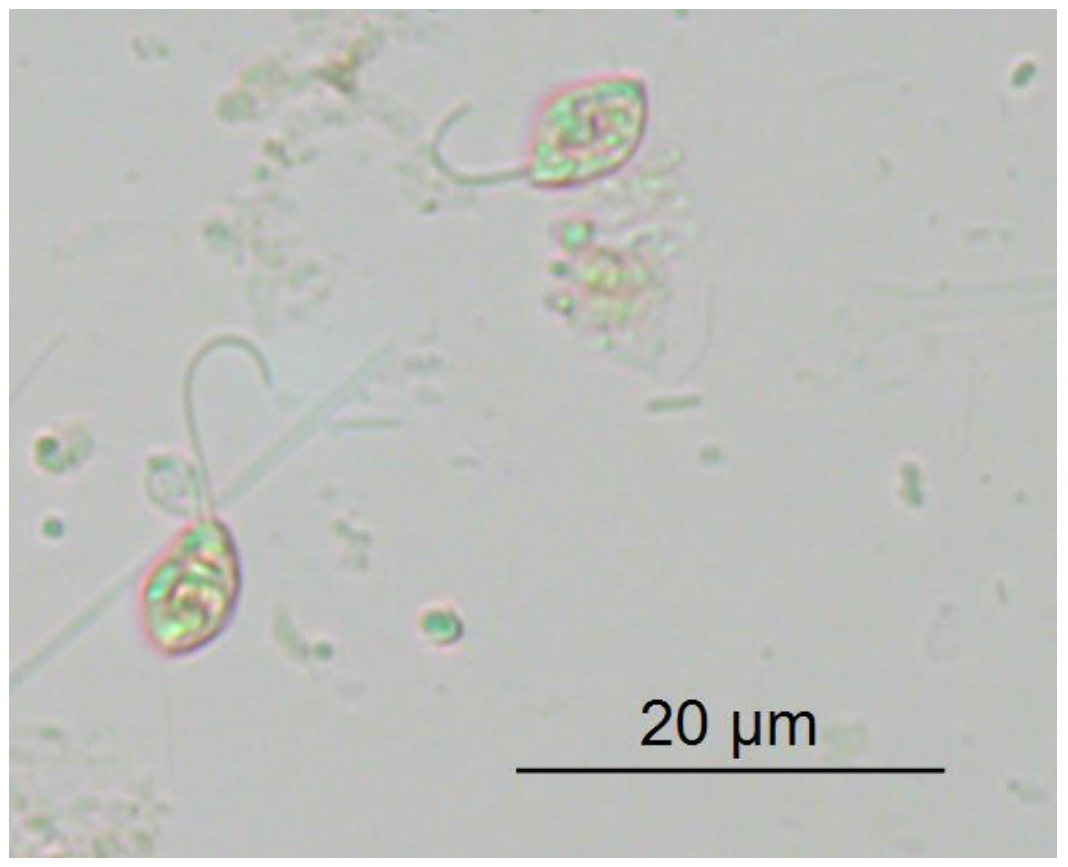

Planktosphaeria spp. cf. G.M. Smith, 1918

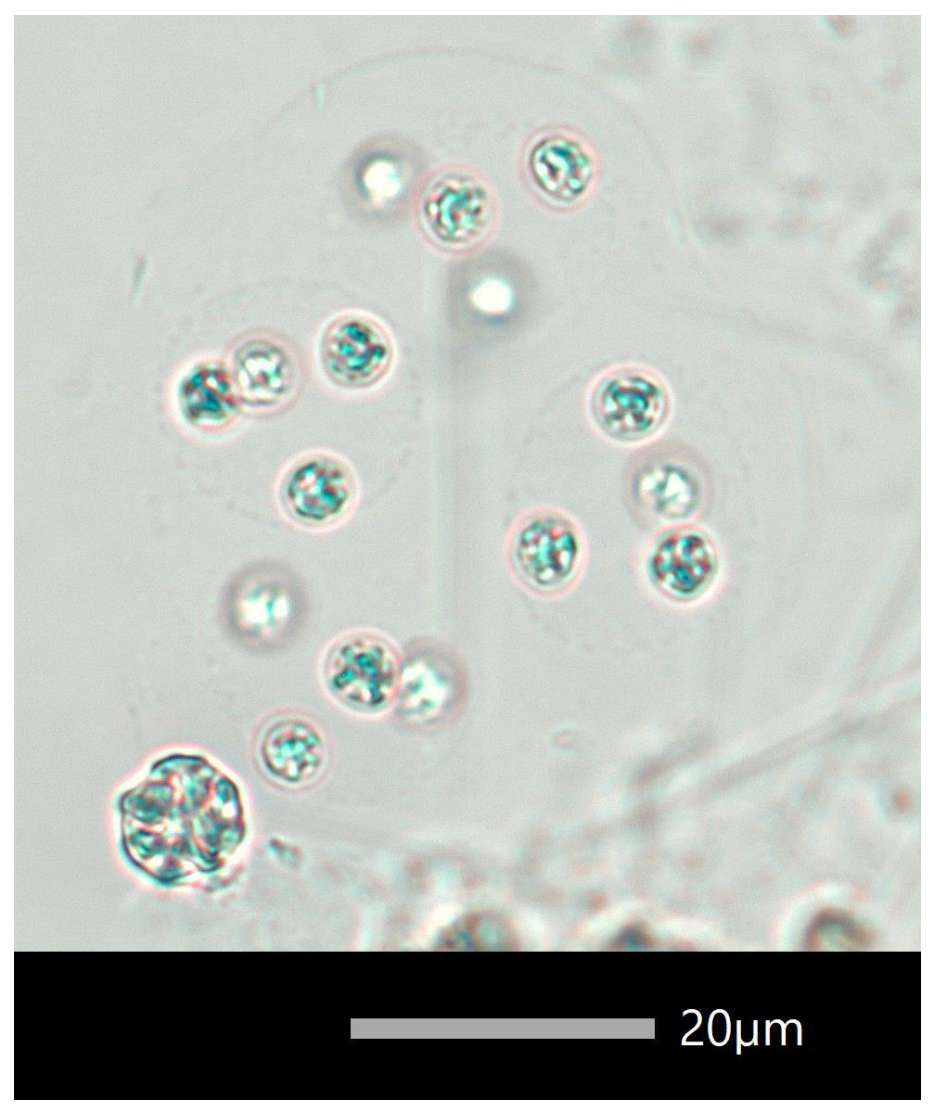


Quadrigula cf. chodatii (Tanner-Füllermann) G.M. Smith, 1920

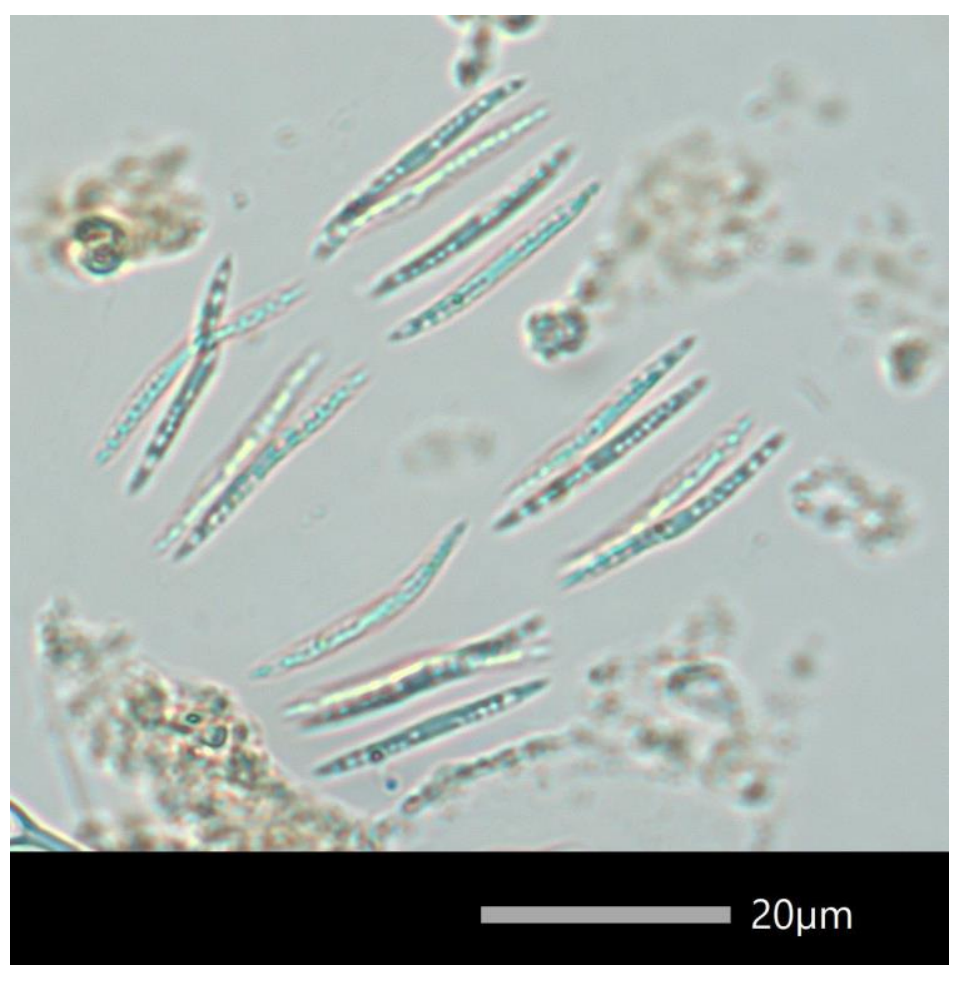

Radiofilum sp. cf. Schmidle, 1894

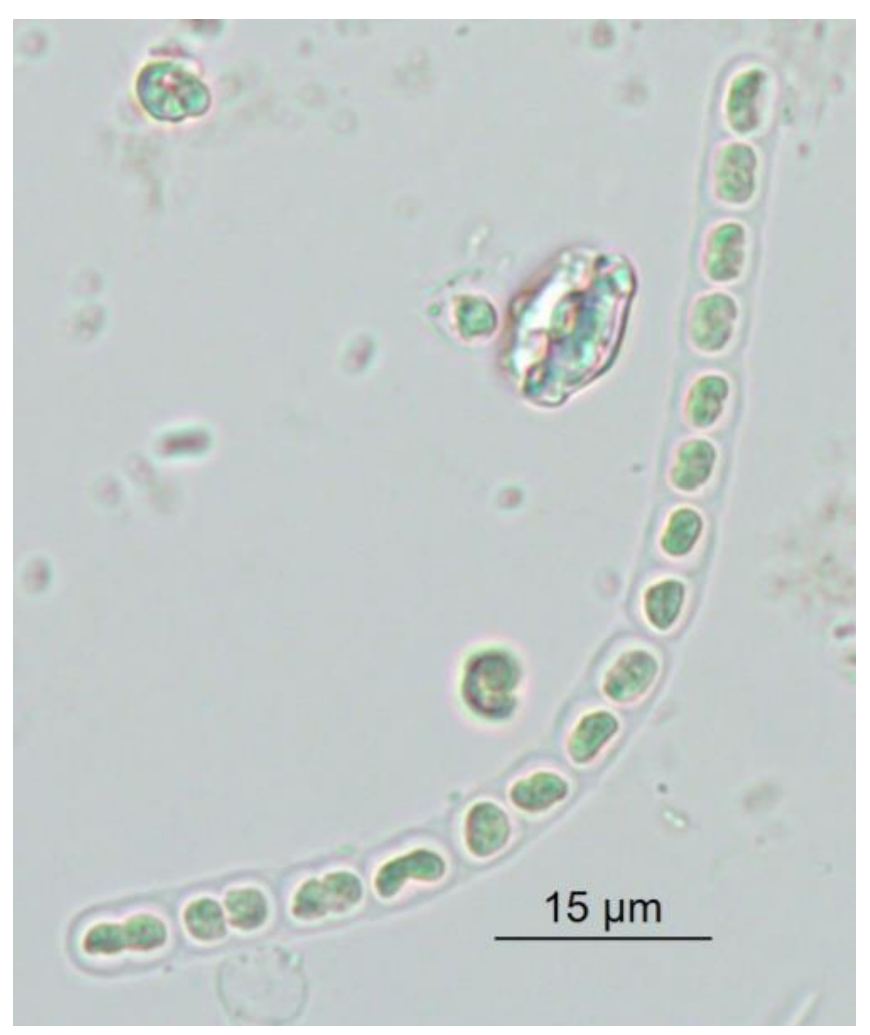


Scenedesmus balatonicus Hortobágyi, 1943

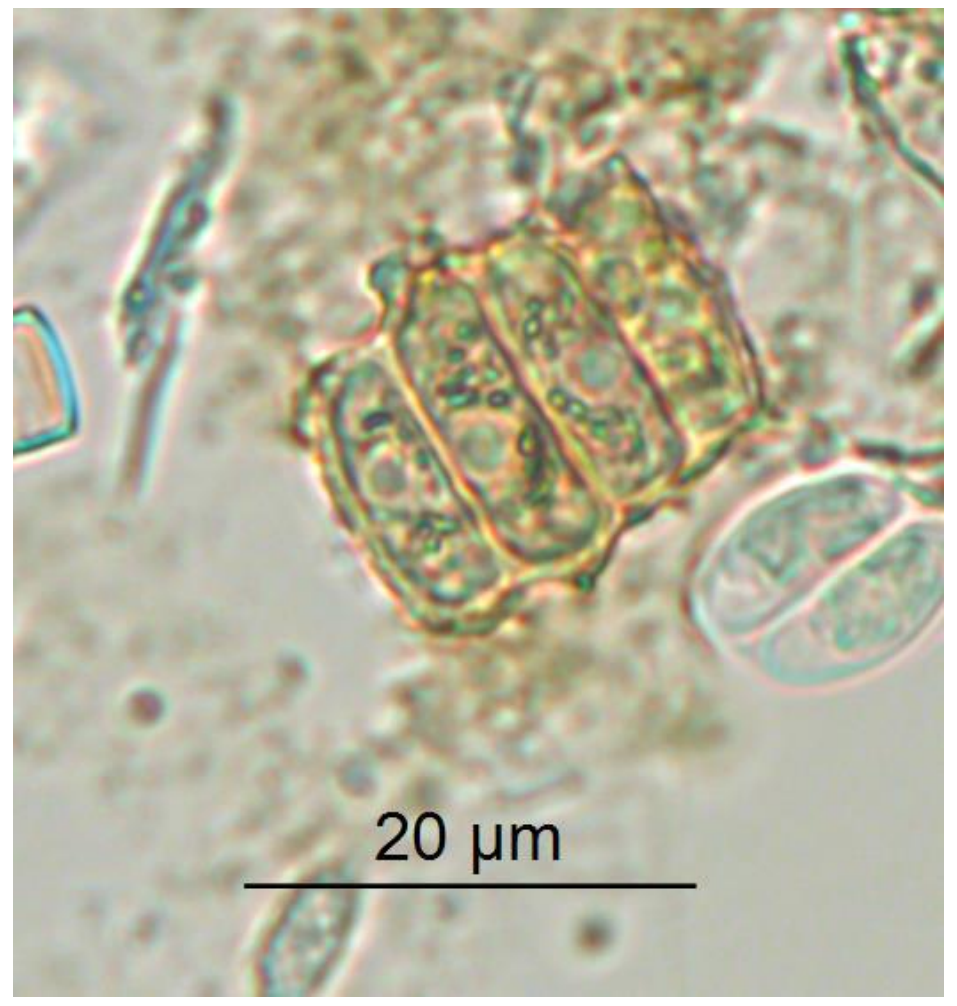

Scenedesmus quadricauda (Turpin) Brébisson, 1835

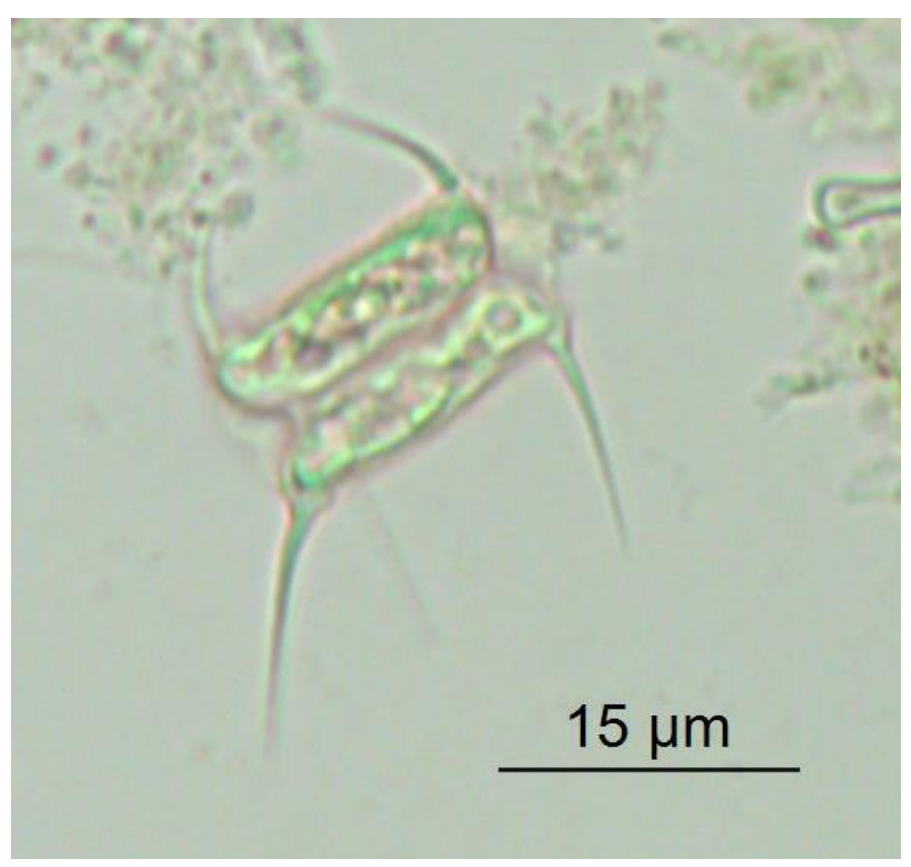


Selenastrum cf. minutum (Nägeli) Collins, 1907

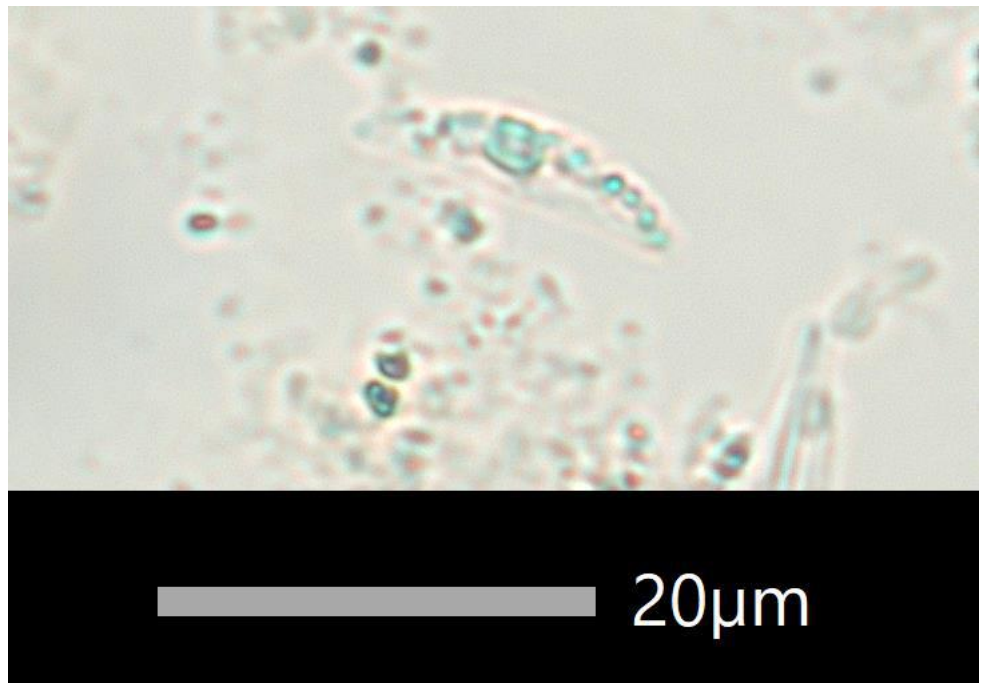

Selenodictyon brasiliense Uherkovich \& A.W.F. Schmidt ex Comas \& Komárek, 1992

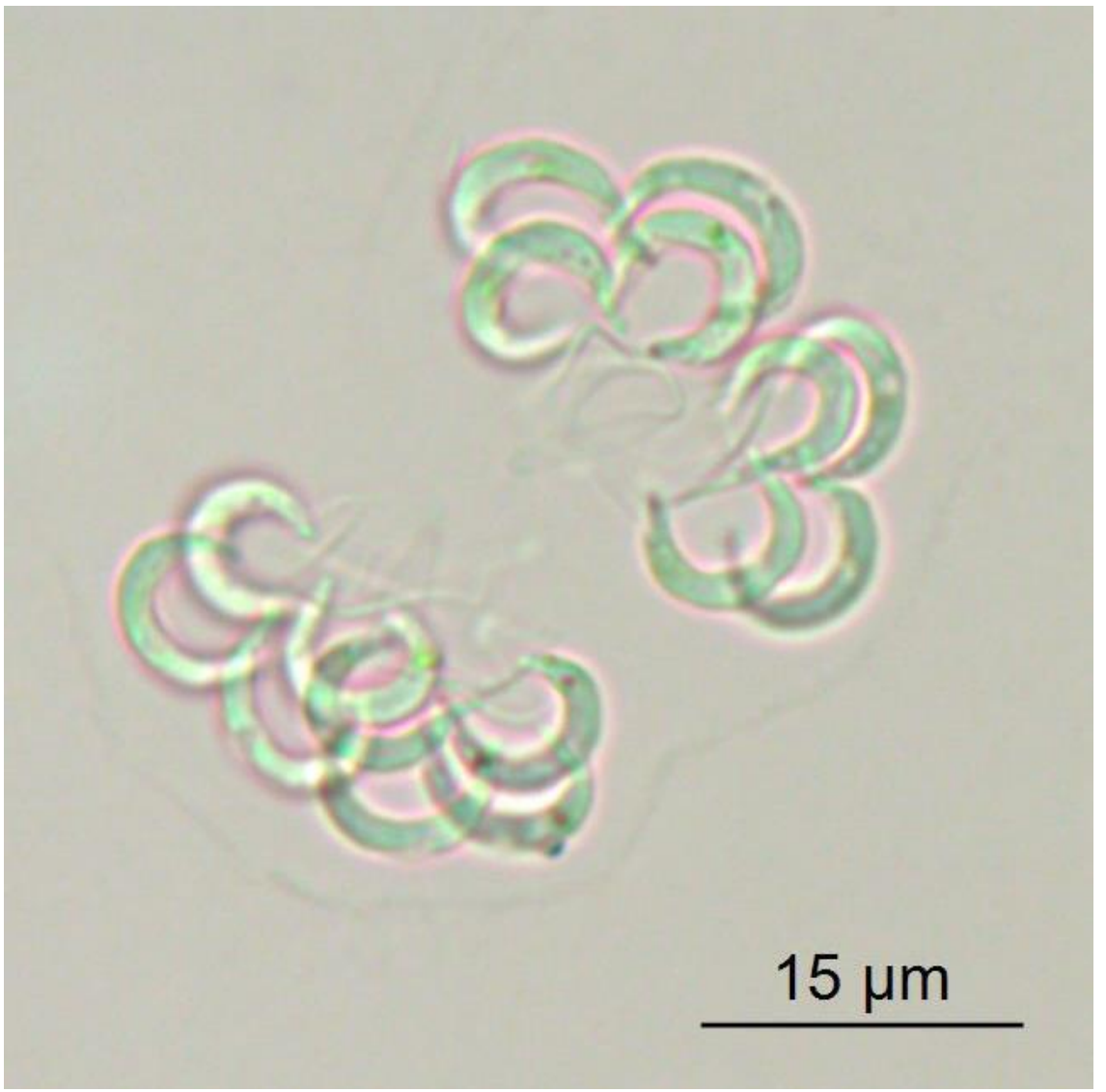


Sphaerocystis sp. Chodat, 1897

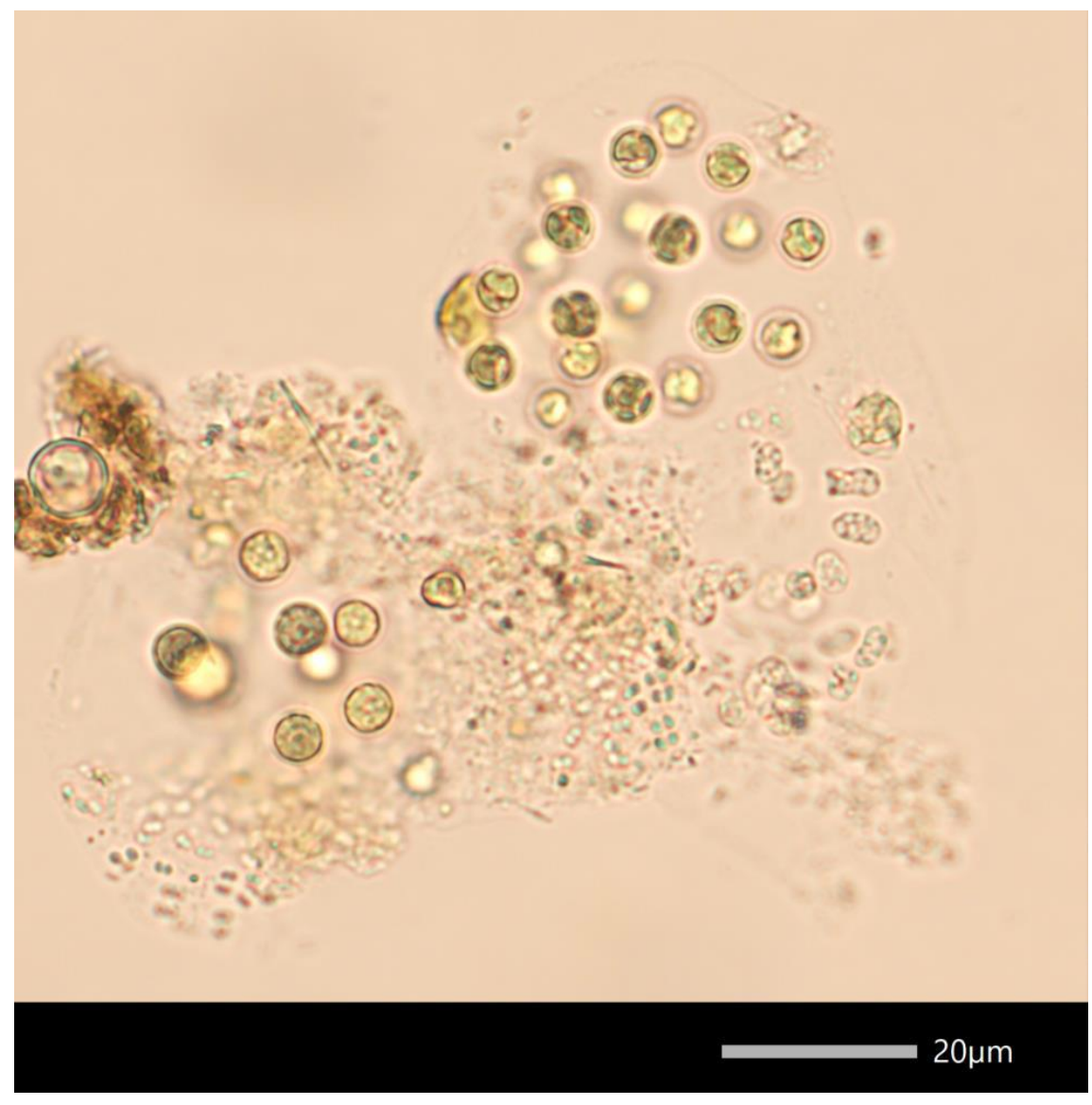

Sphaerocystis sp. SM Chodat, 1897

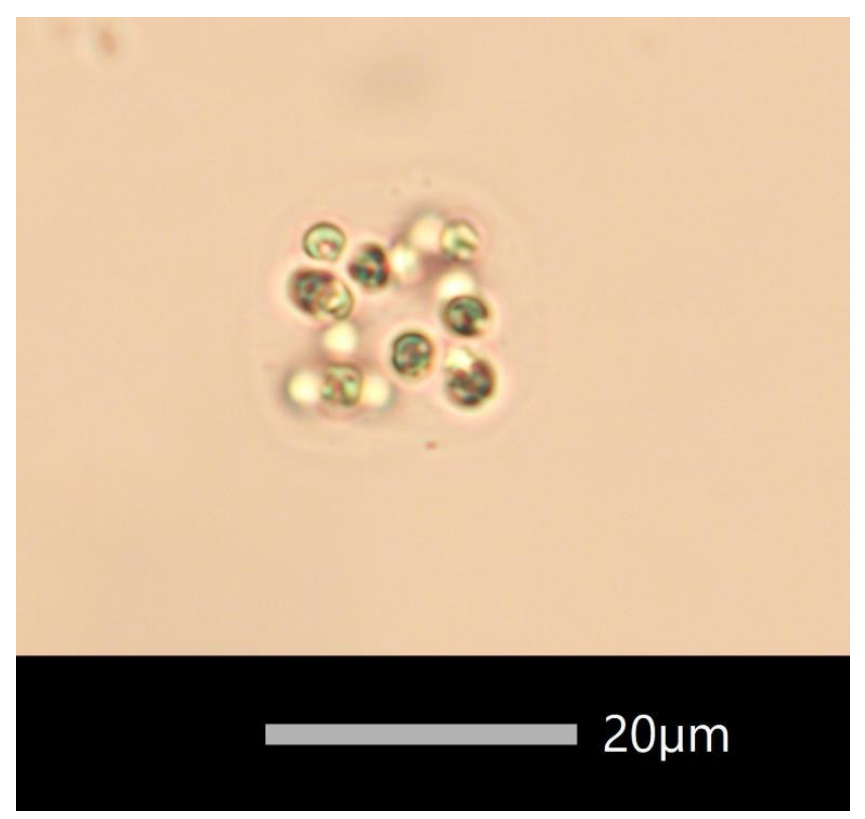


Tetrachlorella alternans (G.M. Smith) Korshikov, 1939

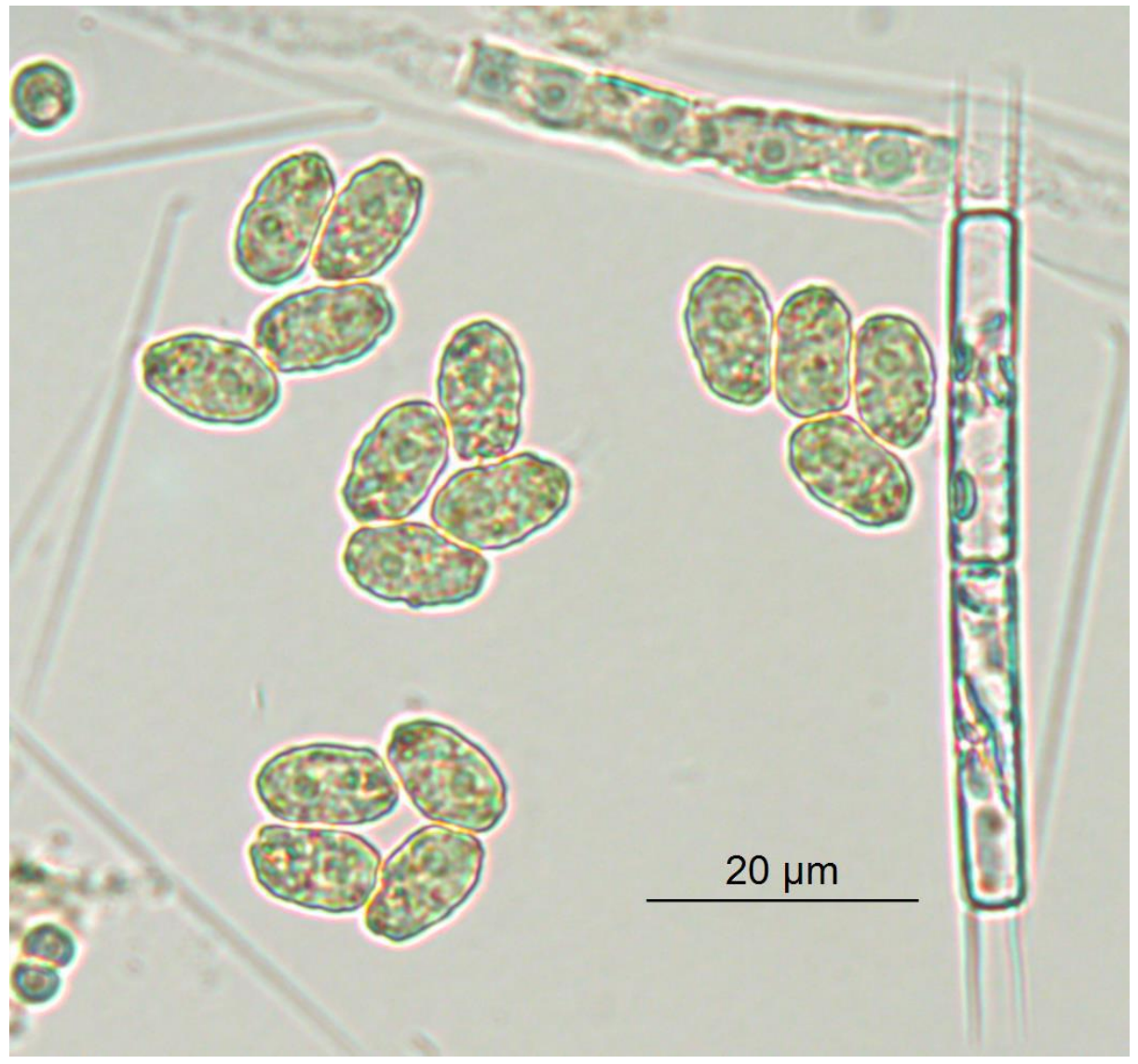

Treubaria setigera (W. Archer) G.M. Smith, 1933

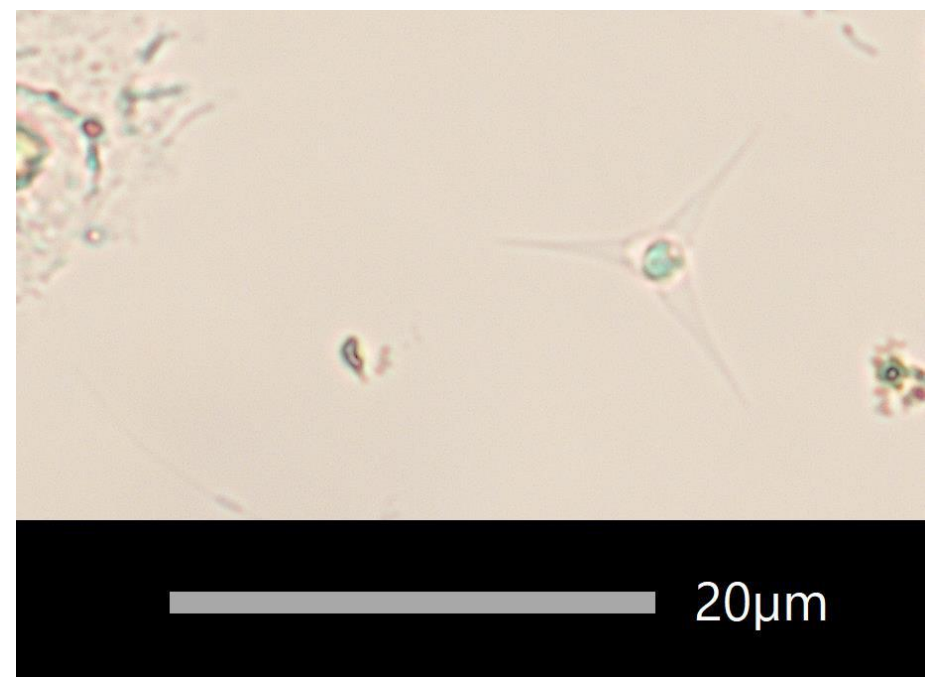




\section{Euglenophyta}

Phacus spp. Dujardin, 1841

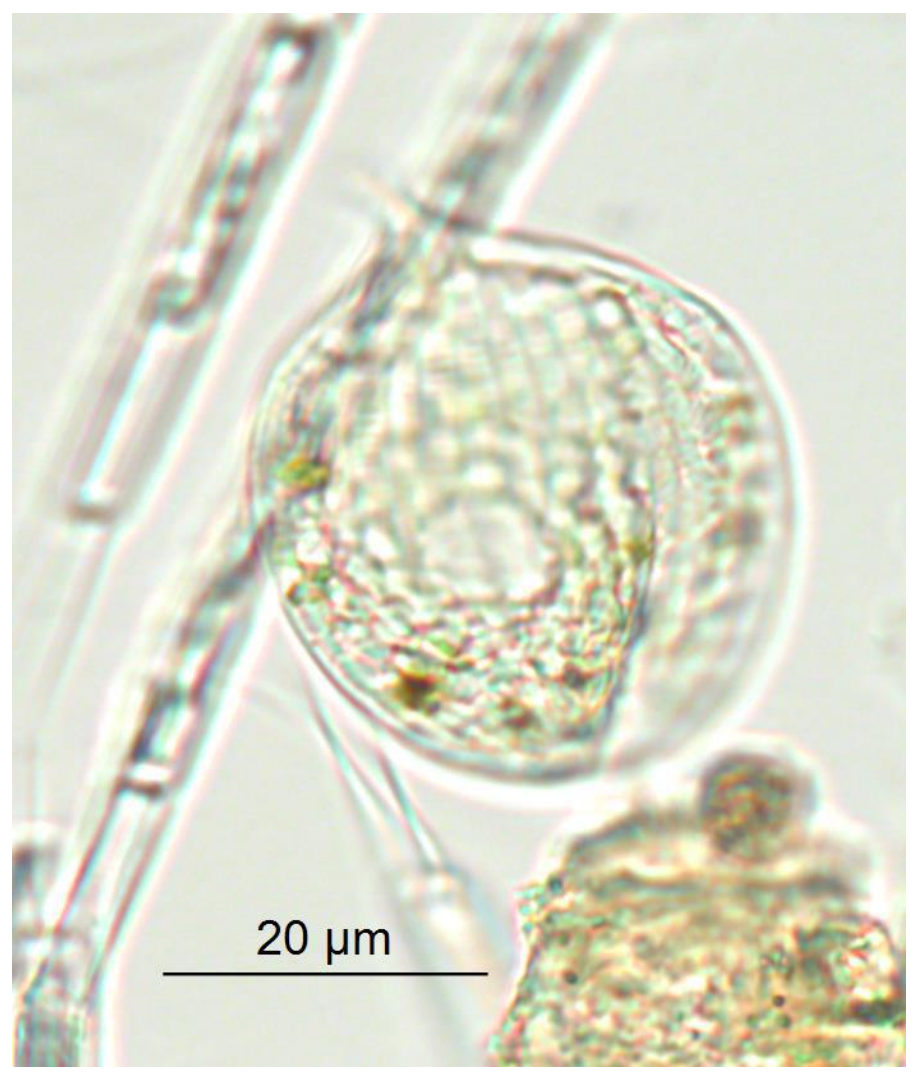

Trachelamonas spp. Ehrenberg, 1834

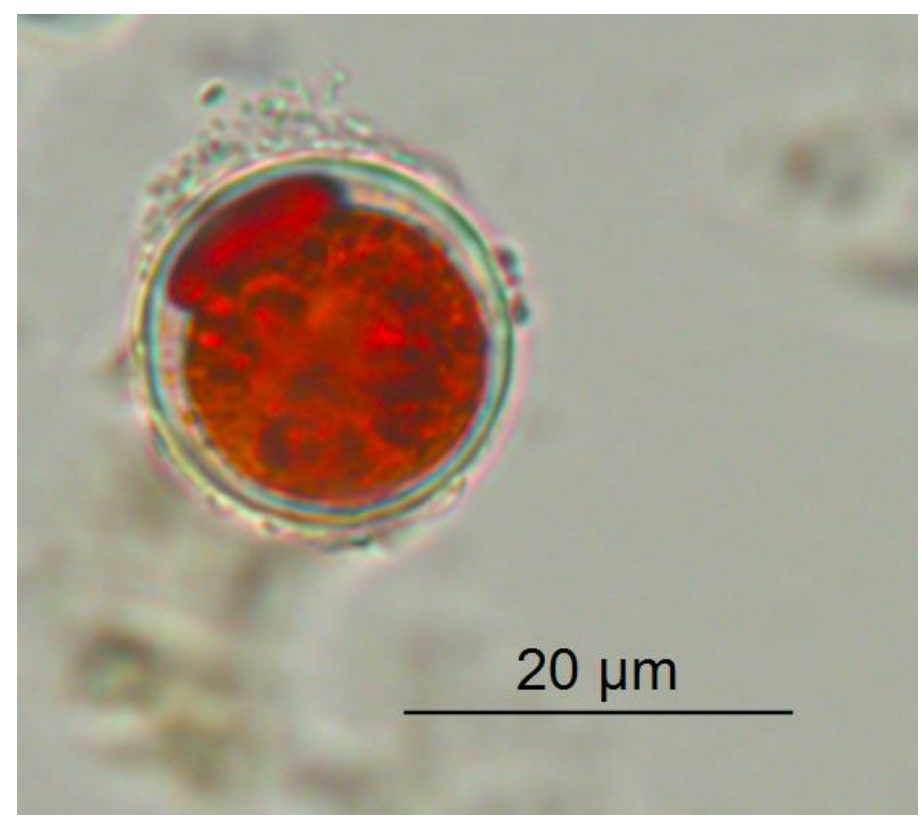




\section{LG Euglenoid}

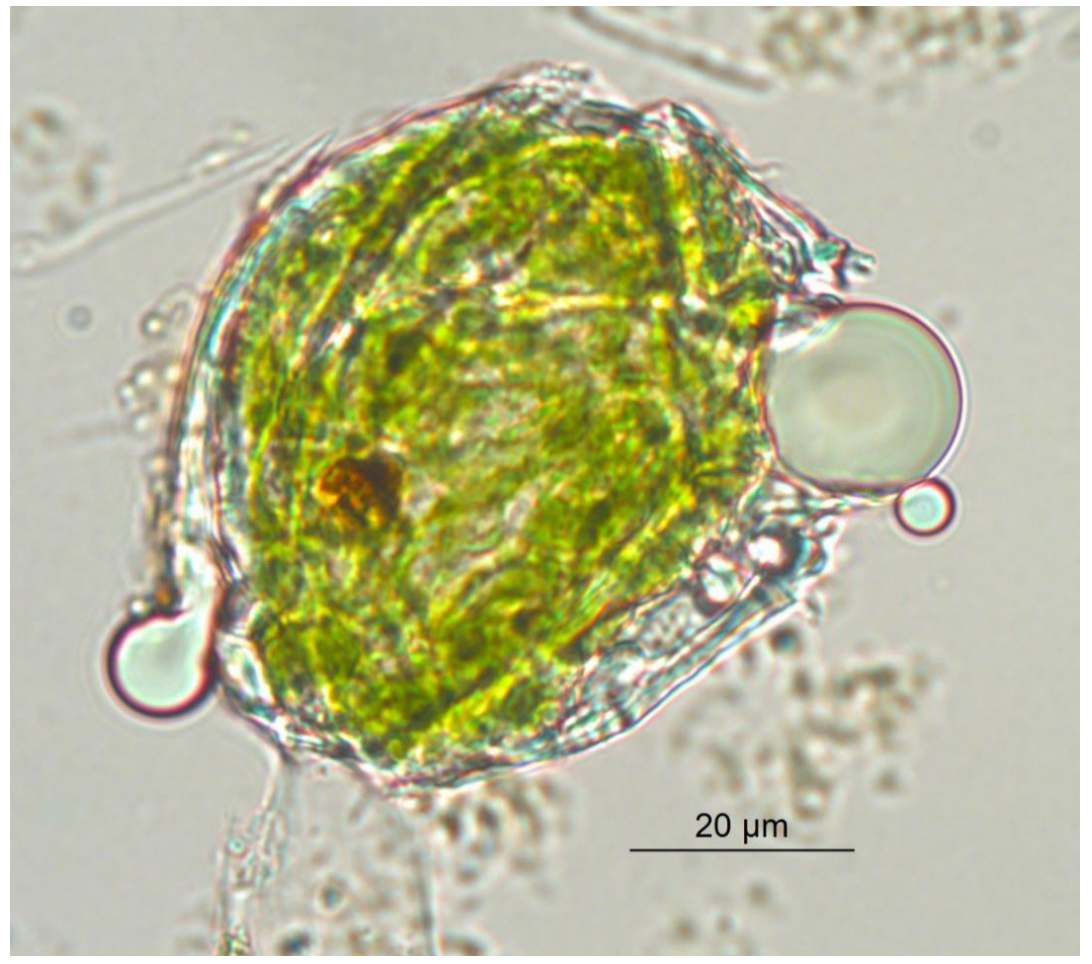

5. Cryptophyta

Cryptomonas spp. Ehrenberg, 1831

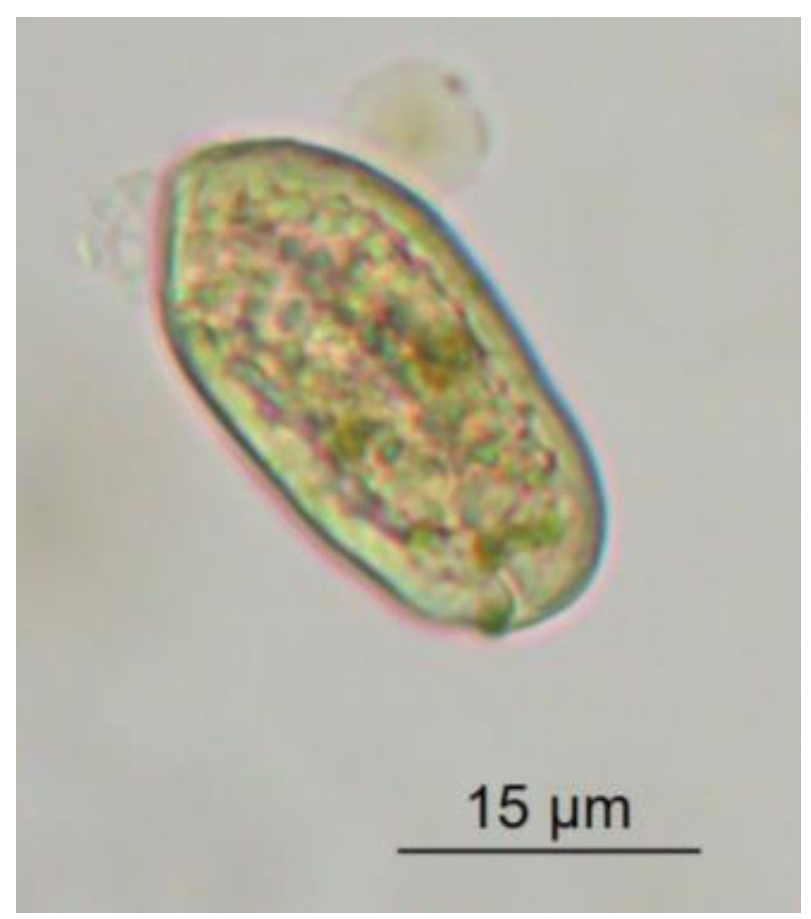




\section{Ochrophyta}

\section{Crysophyte cyst}
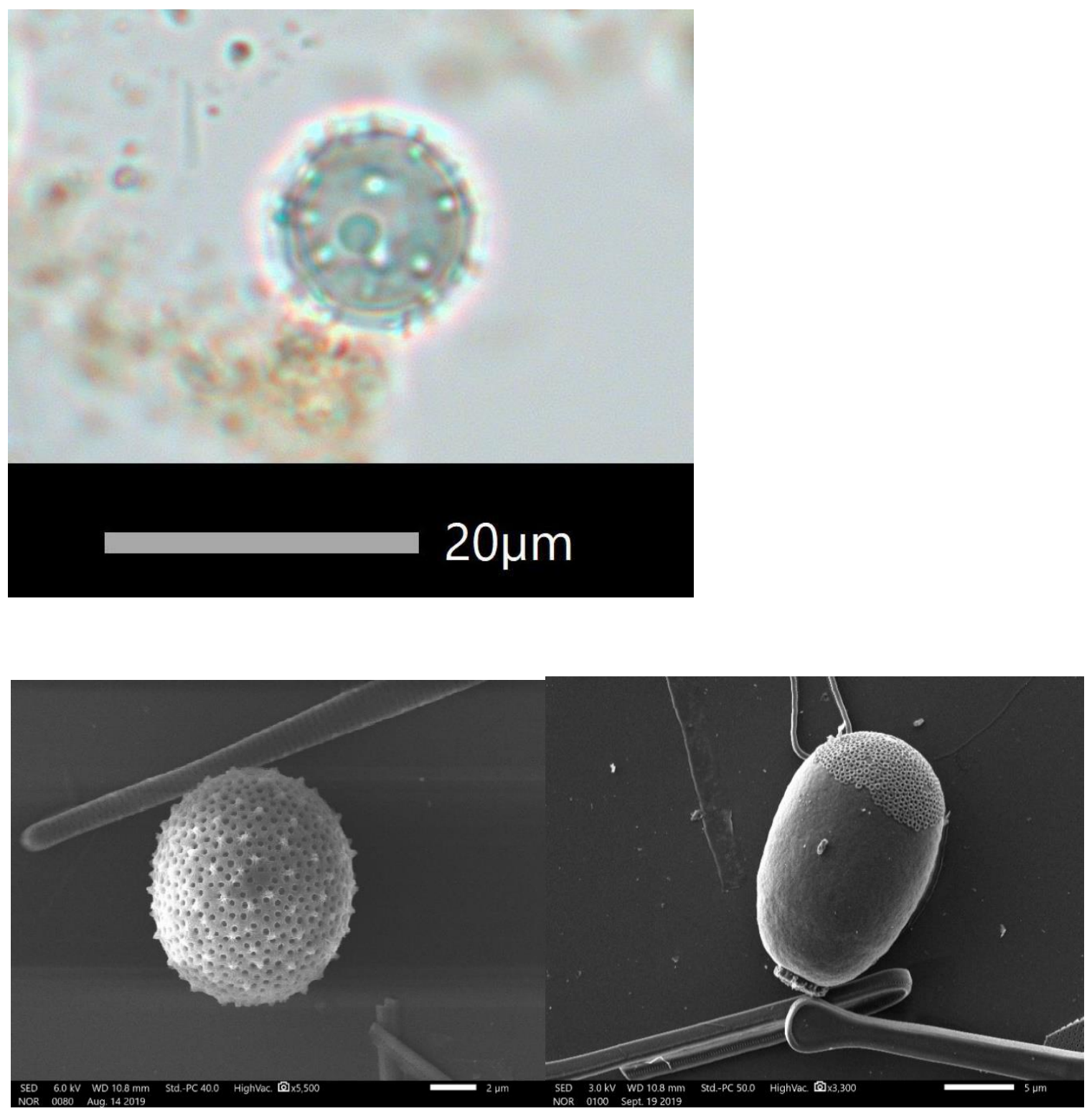
Dinobryon acuminatum Ruttner, 1913

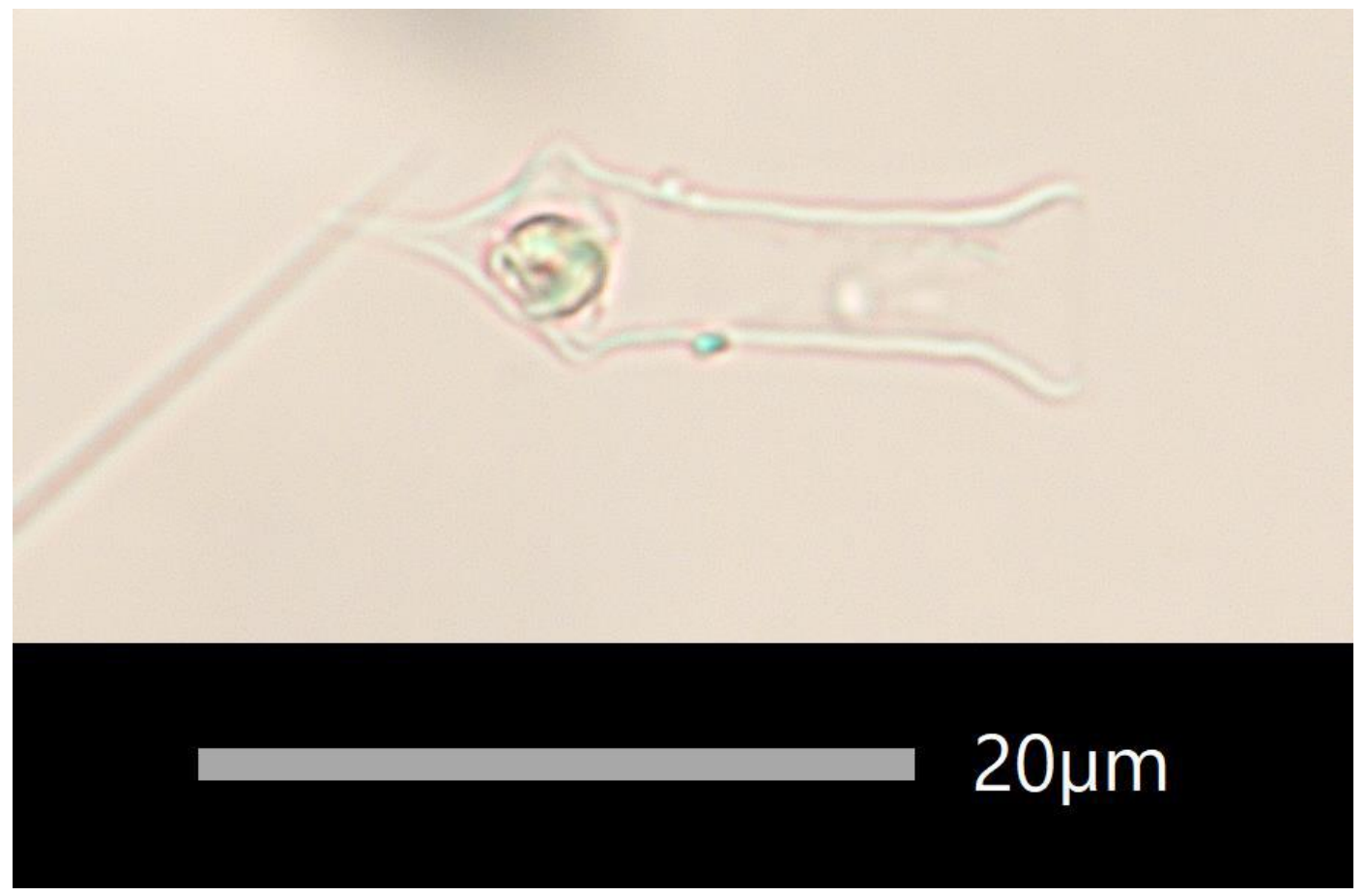


Dinobryon bavaricum Imhof, 1890
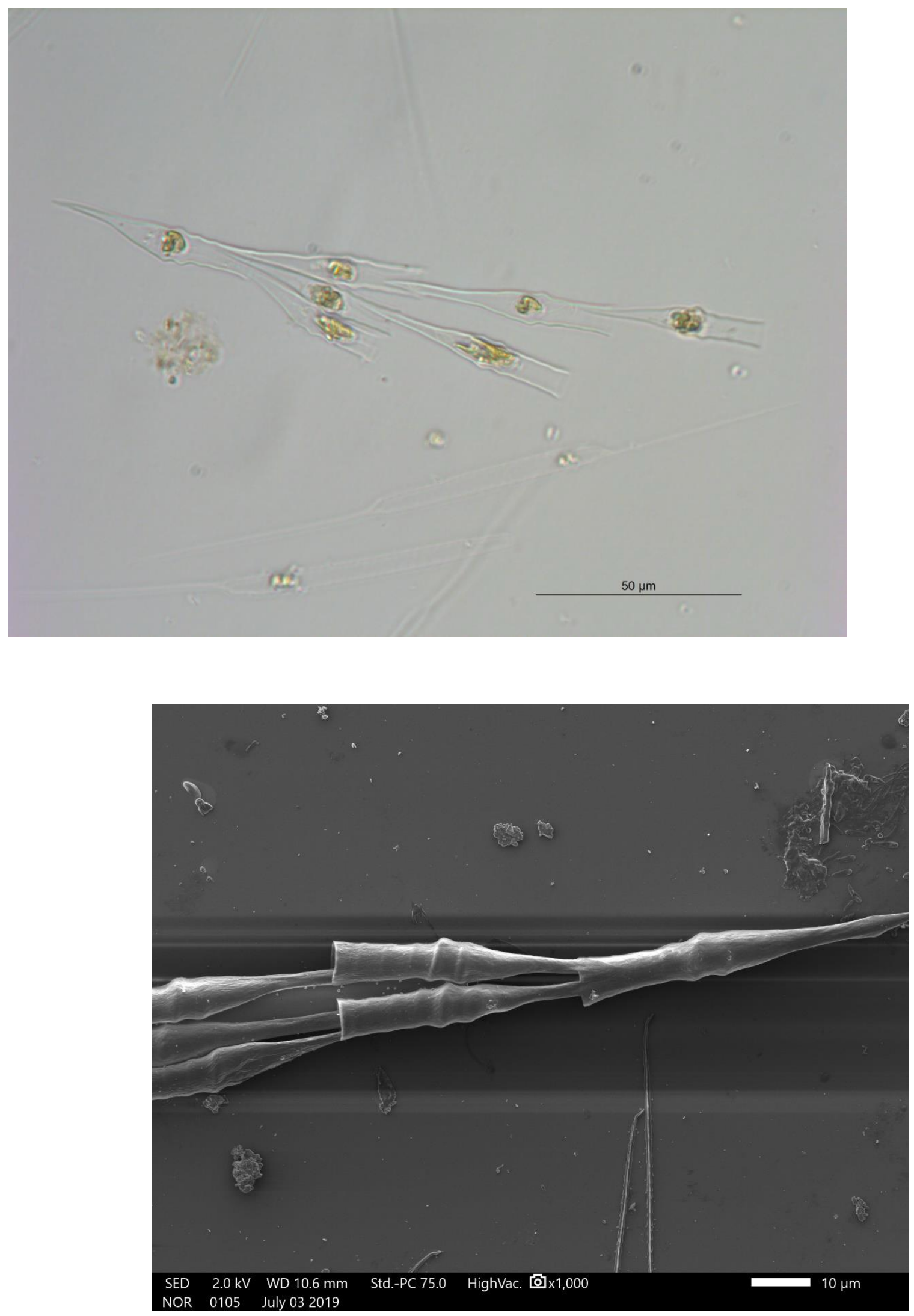
Dinobryon crenulatum West \& G.S. West, 1909
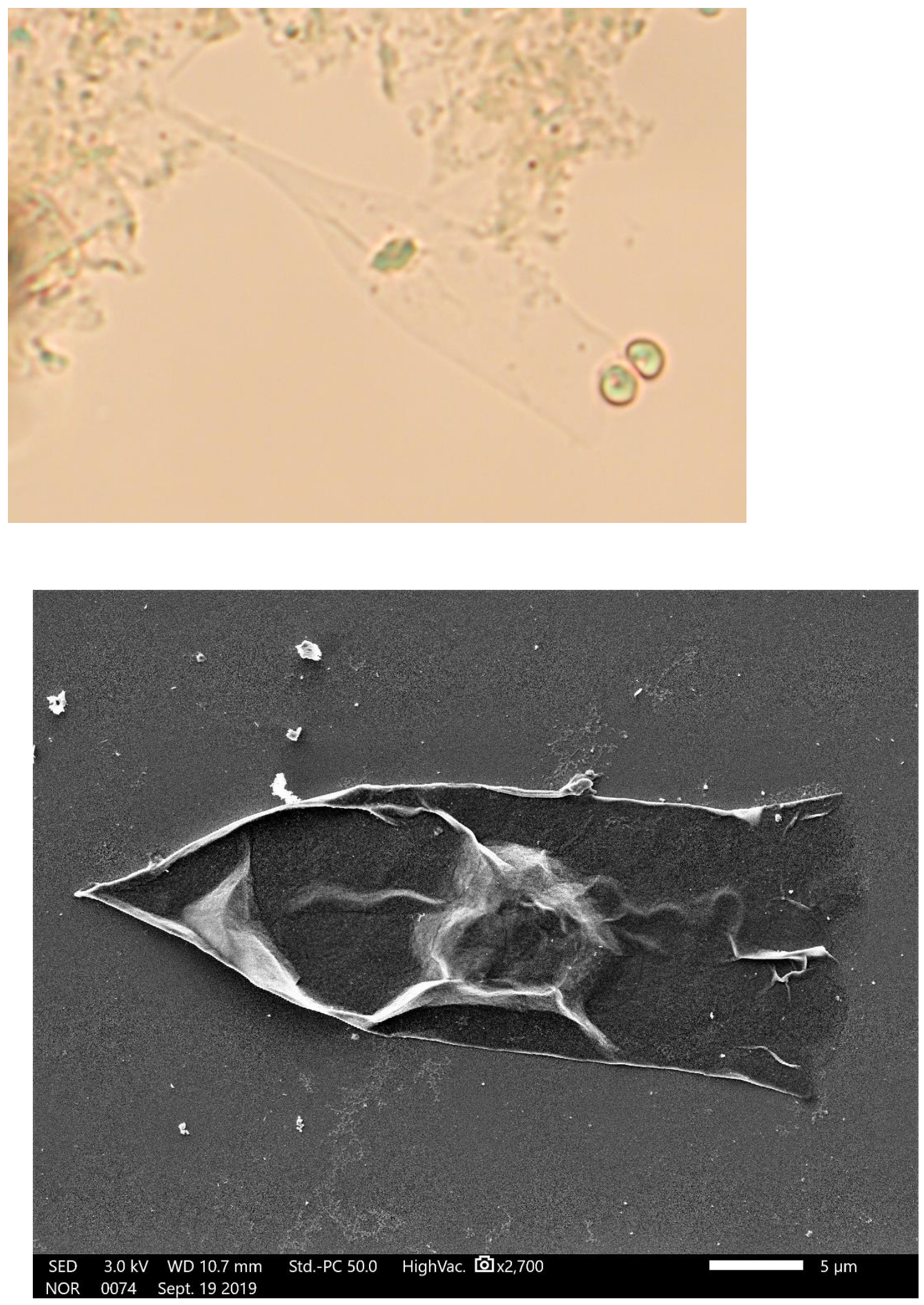
Dinobryon cylindricum O.E. Imhof, 1887
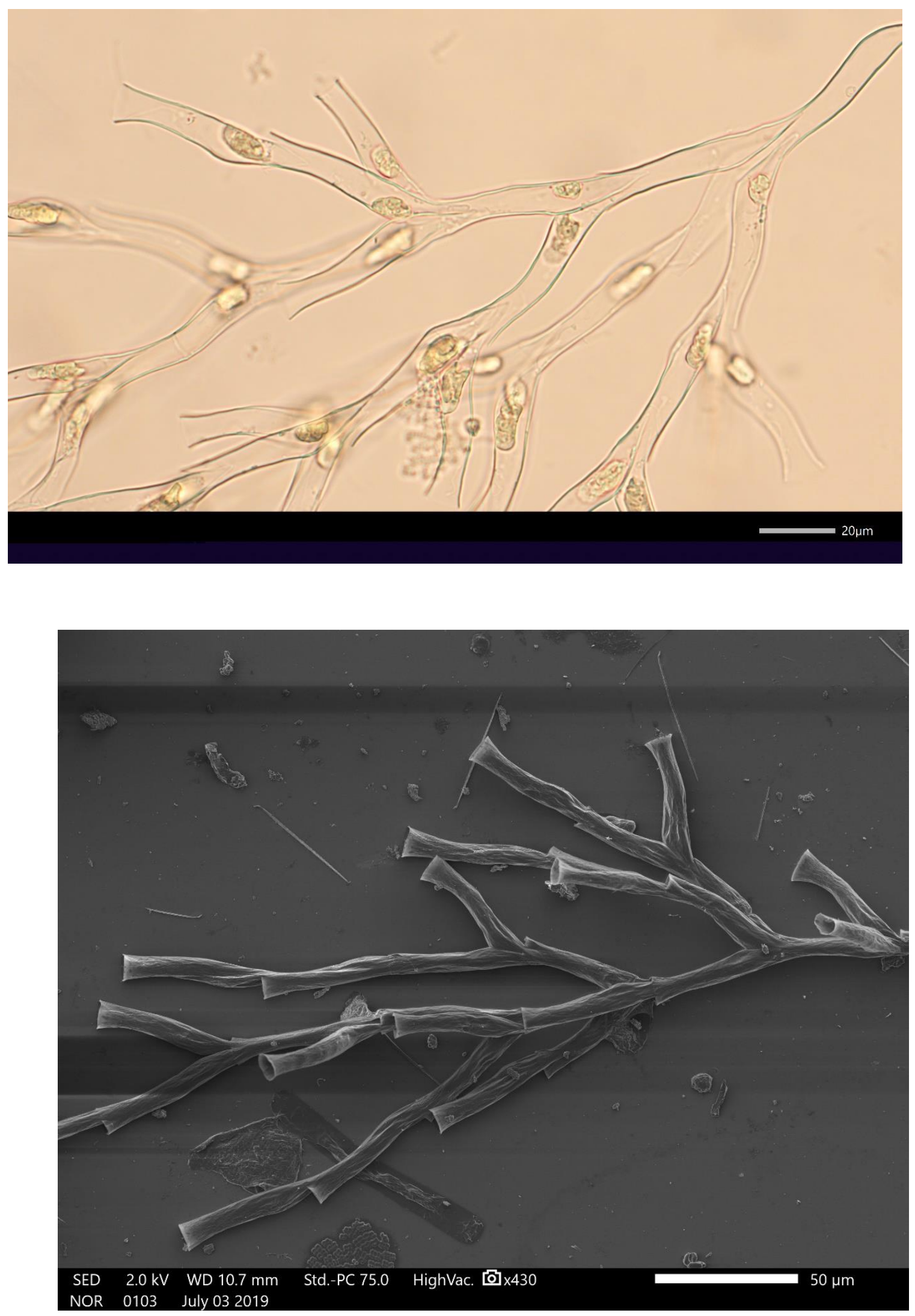
Gonyostomum semen (Ehrenberg) Diesing, 1866

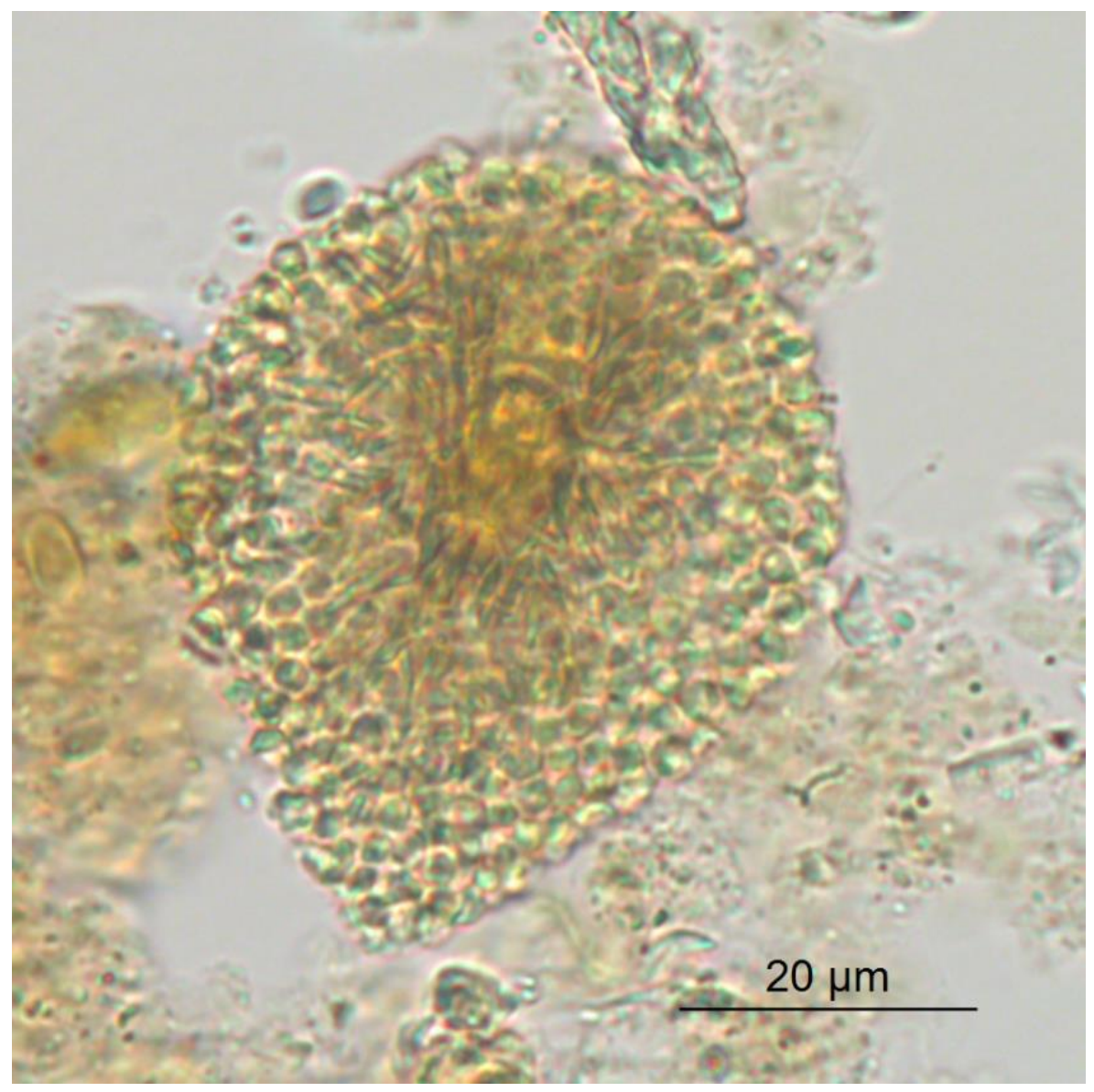


Mallomonas caudata Iwanoff [Ivanov], 1899
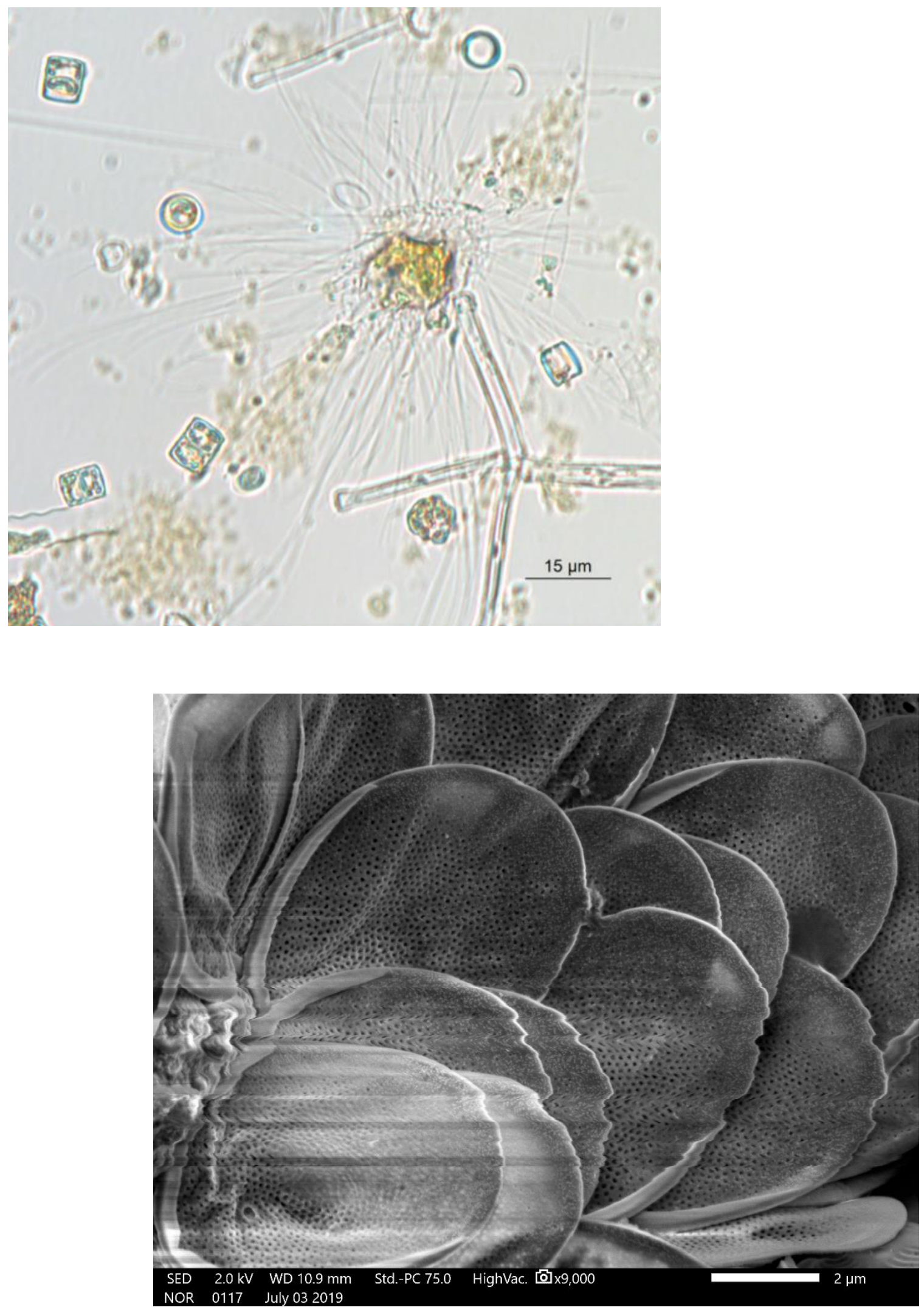
Mallomonas deurrschmidtiae P.A. Siver, J.S. Hamer, \& H.J. Kling, 1990
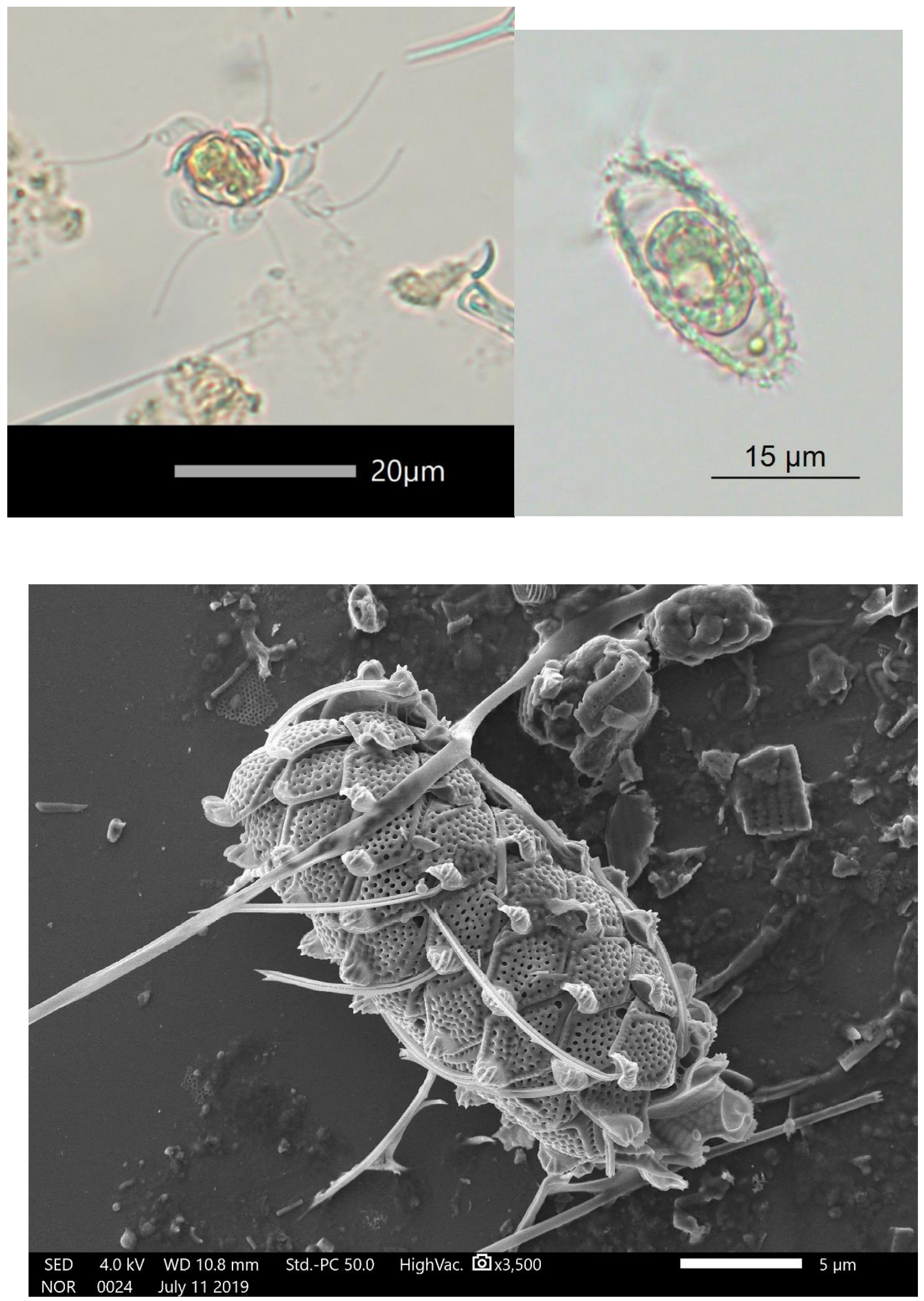
Mallomonas favosa K.H. Nicholls, 1984
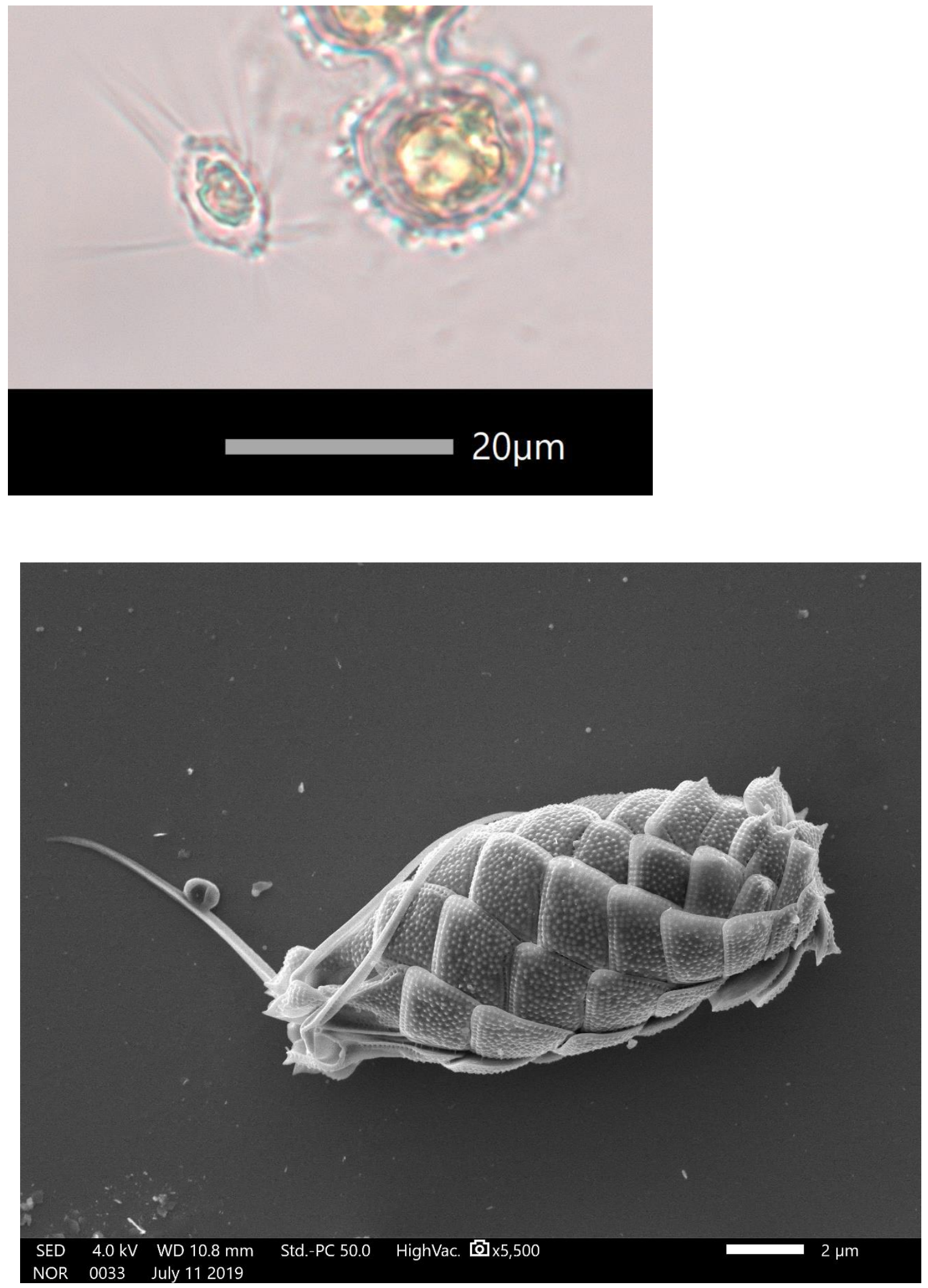
Mallomonas transsylvanica L.S. Péterfi \& Momeu, 1976
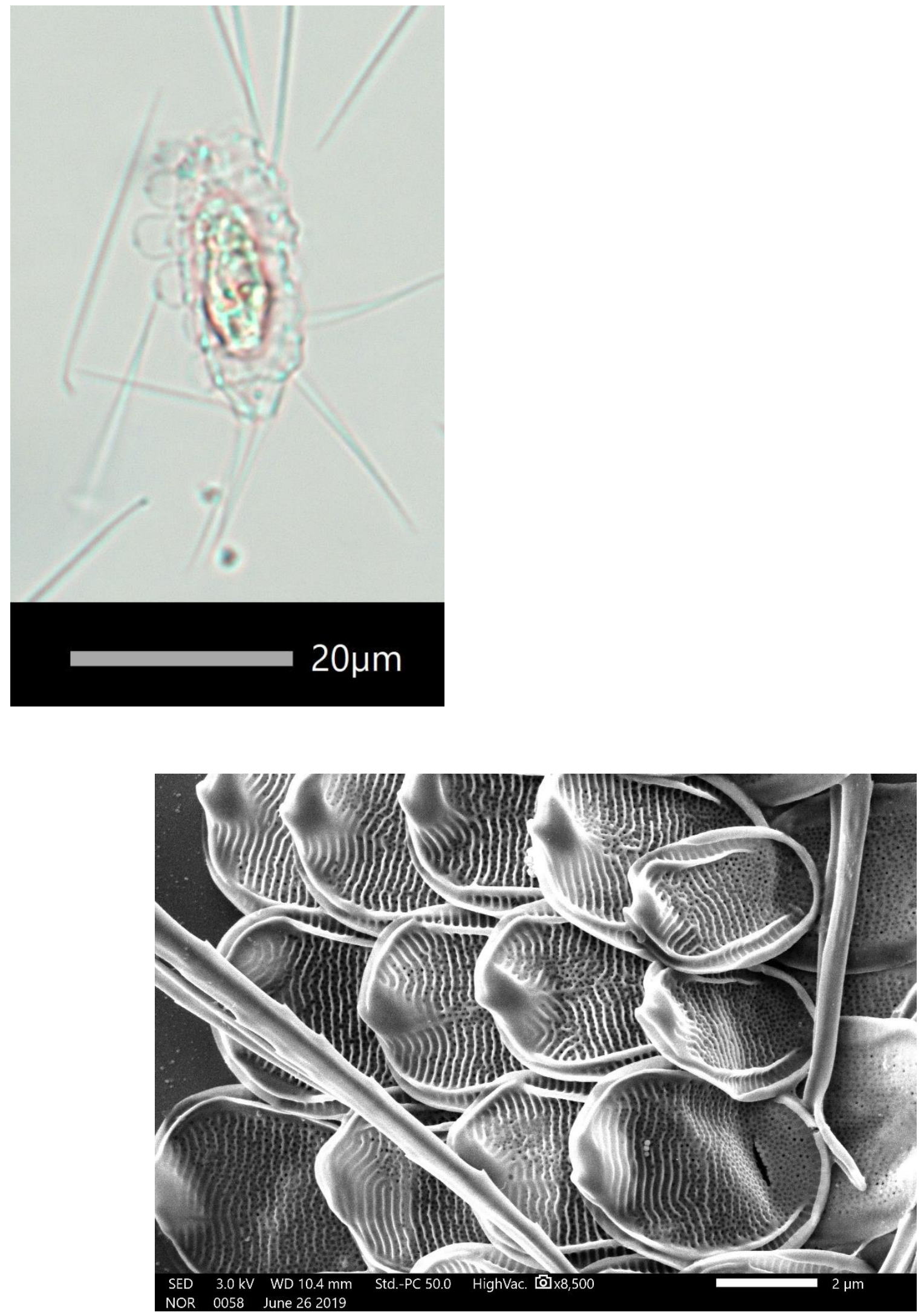
Stipitococcus lauterbornei Schmidle, 1902

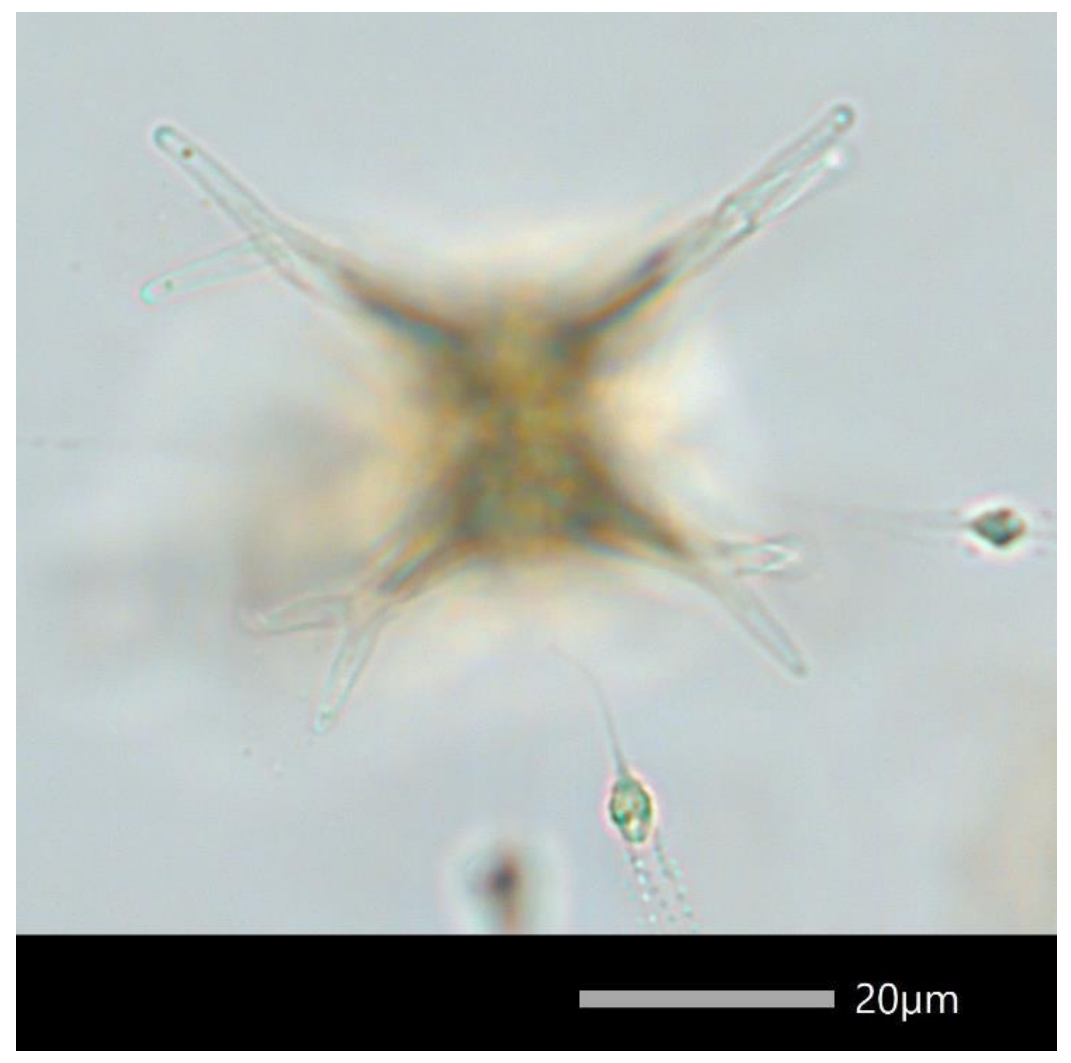


Synura petersenii Korshikov, 1929
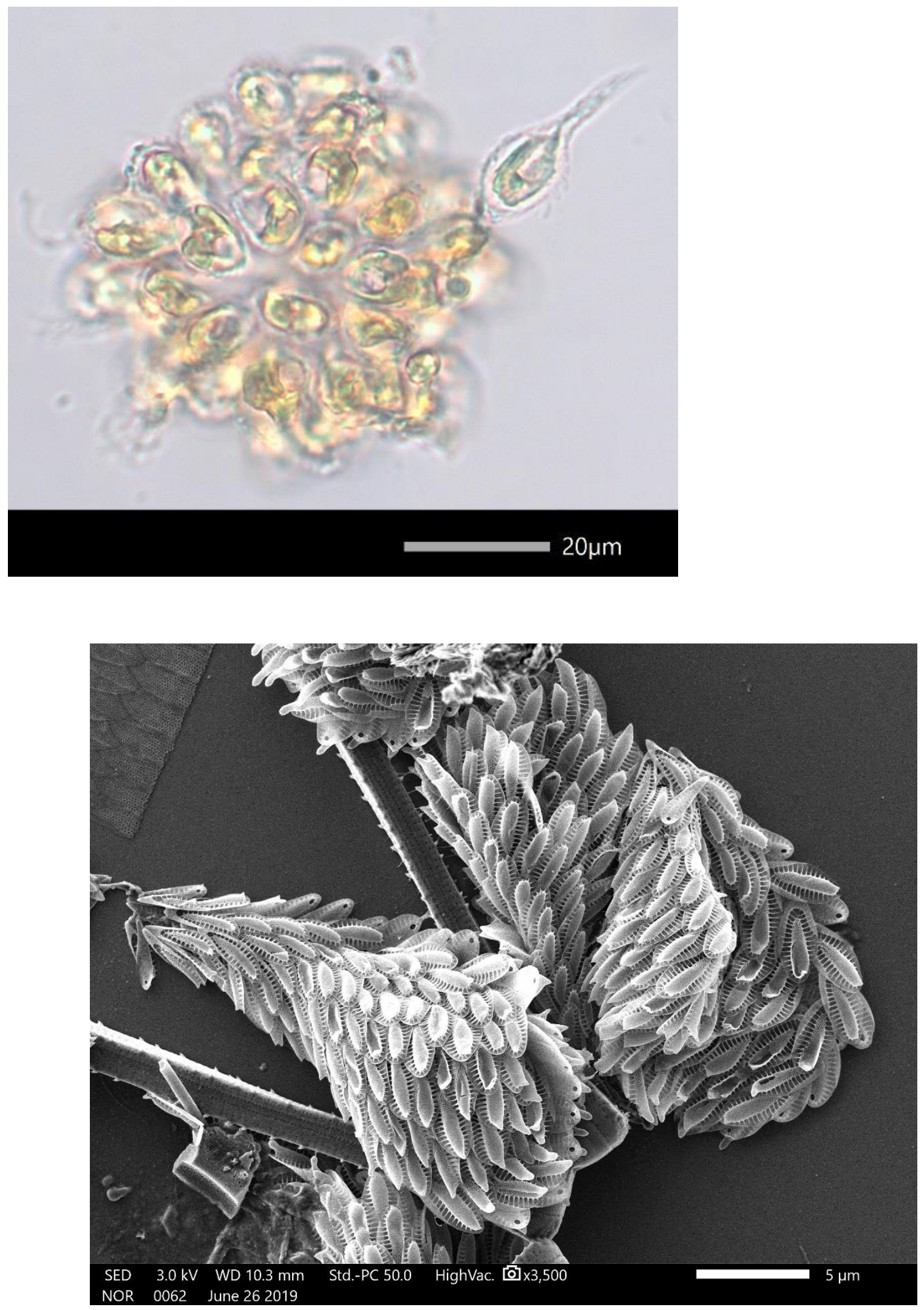


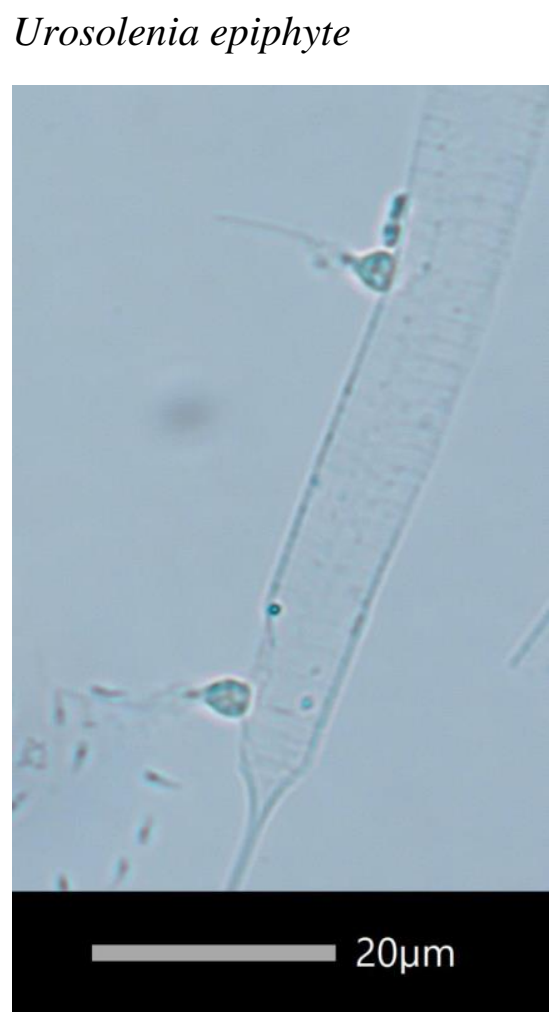

7. Miozoa (Dinoflagellata)

Apocalathium cf. aciculiferum (Lemmermann) Craverio, Daugbjerg, Moestrup, \& Calado, 2016

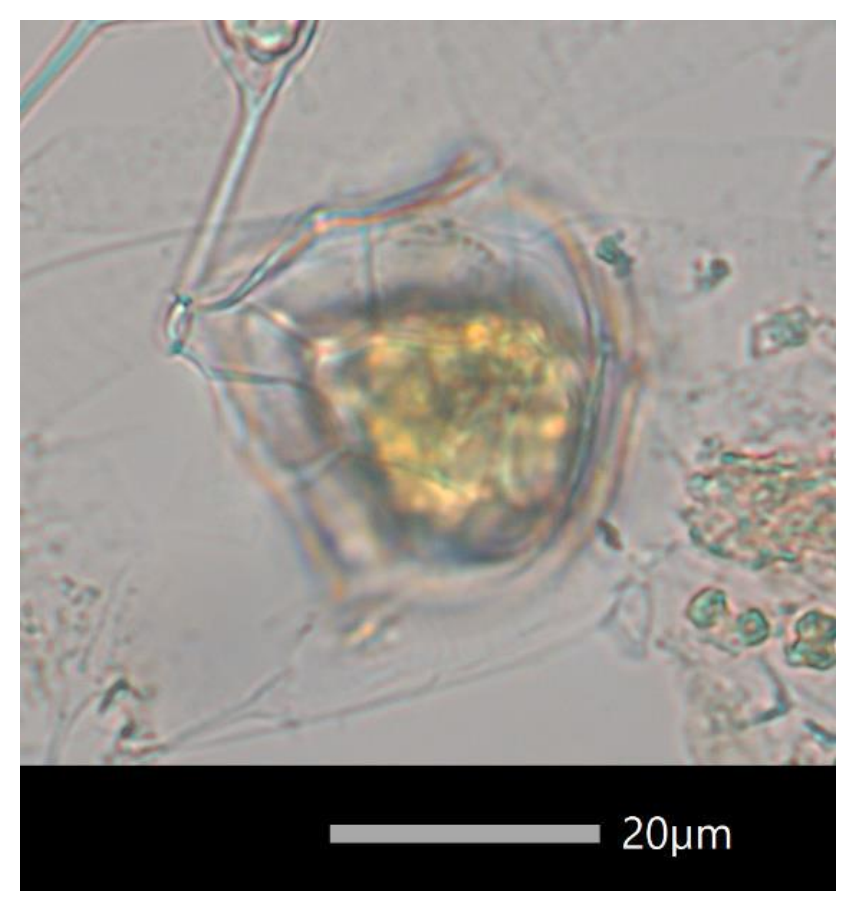


Ceratium carolinianum (Bailey) Jörgensen, 1911
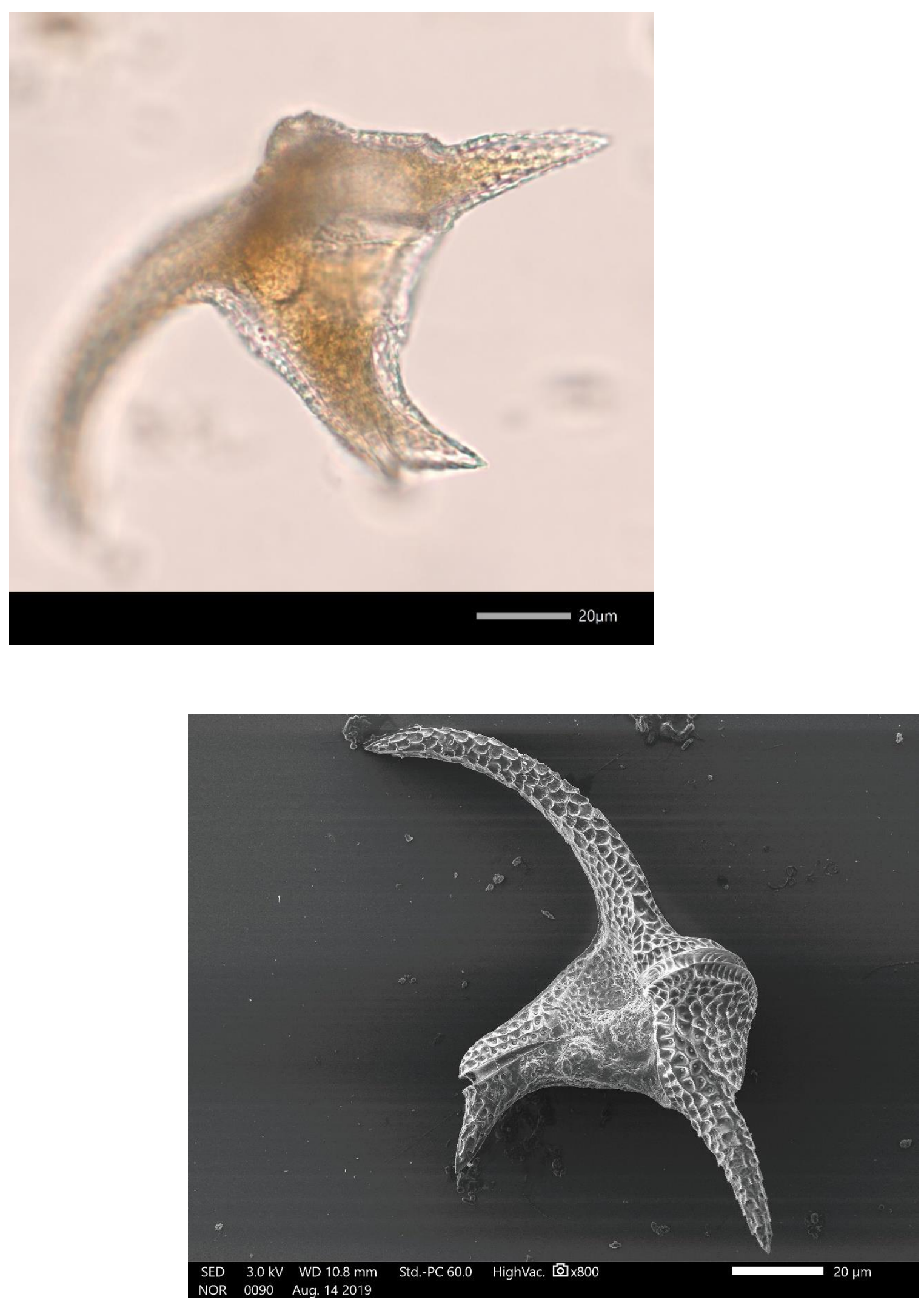
Fusiperidinium wisconsinense (Eddy) F.M.G. McCarthy, H.F. Gu, K.N. Mertens, \& Carbonell-Moore, 2018
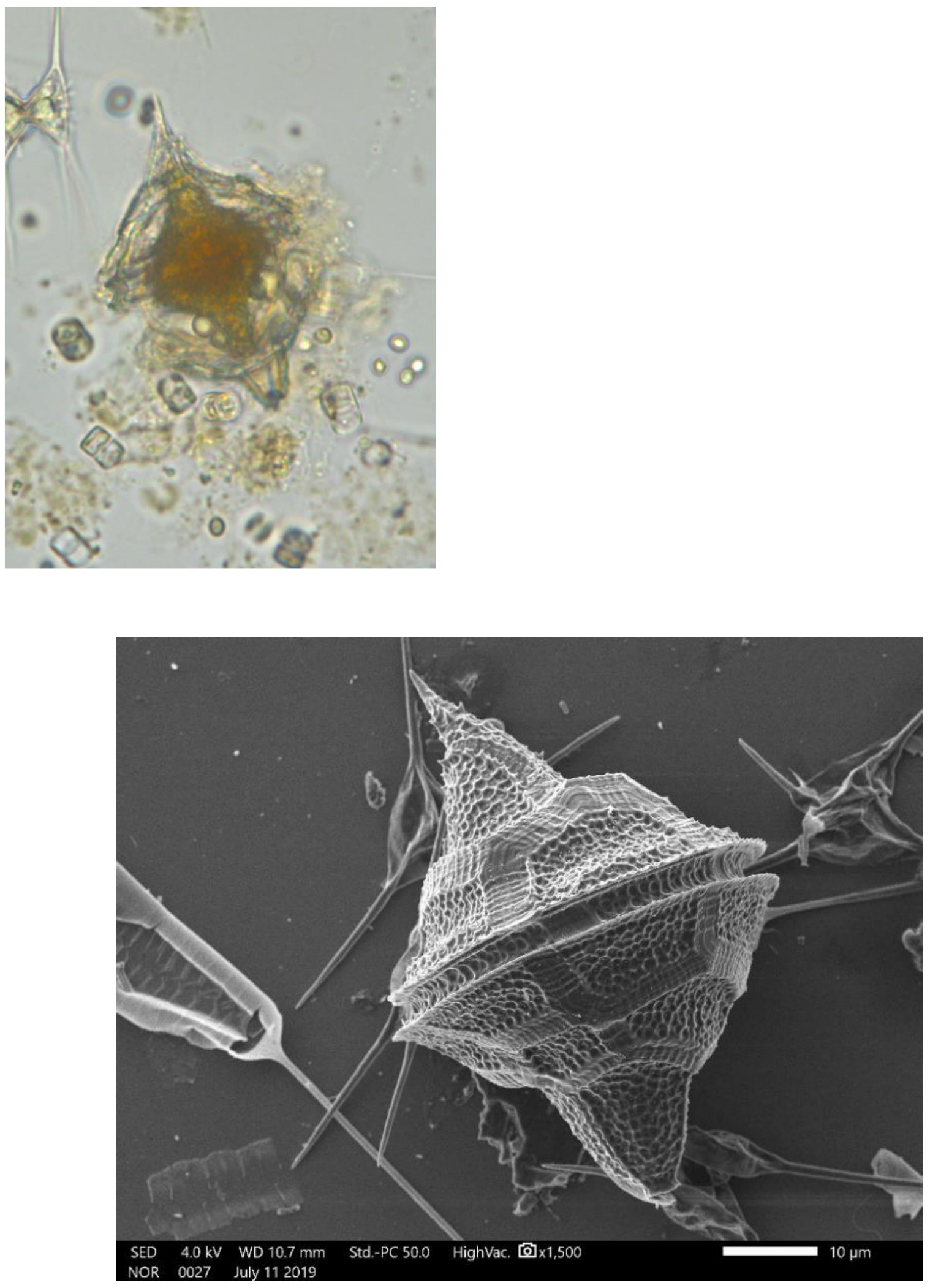
Naiadinium polonicum (Woloszynska) Carty, 2014

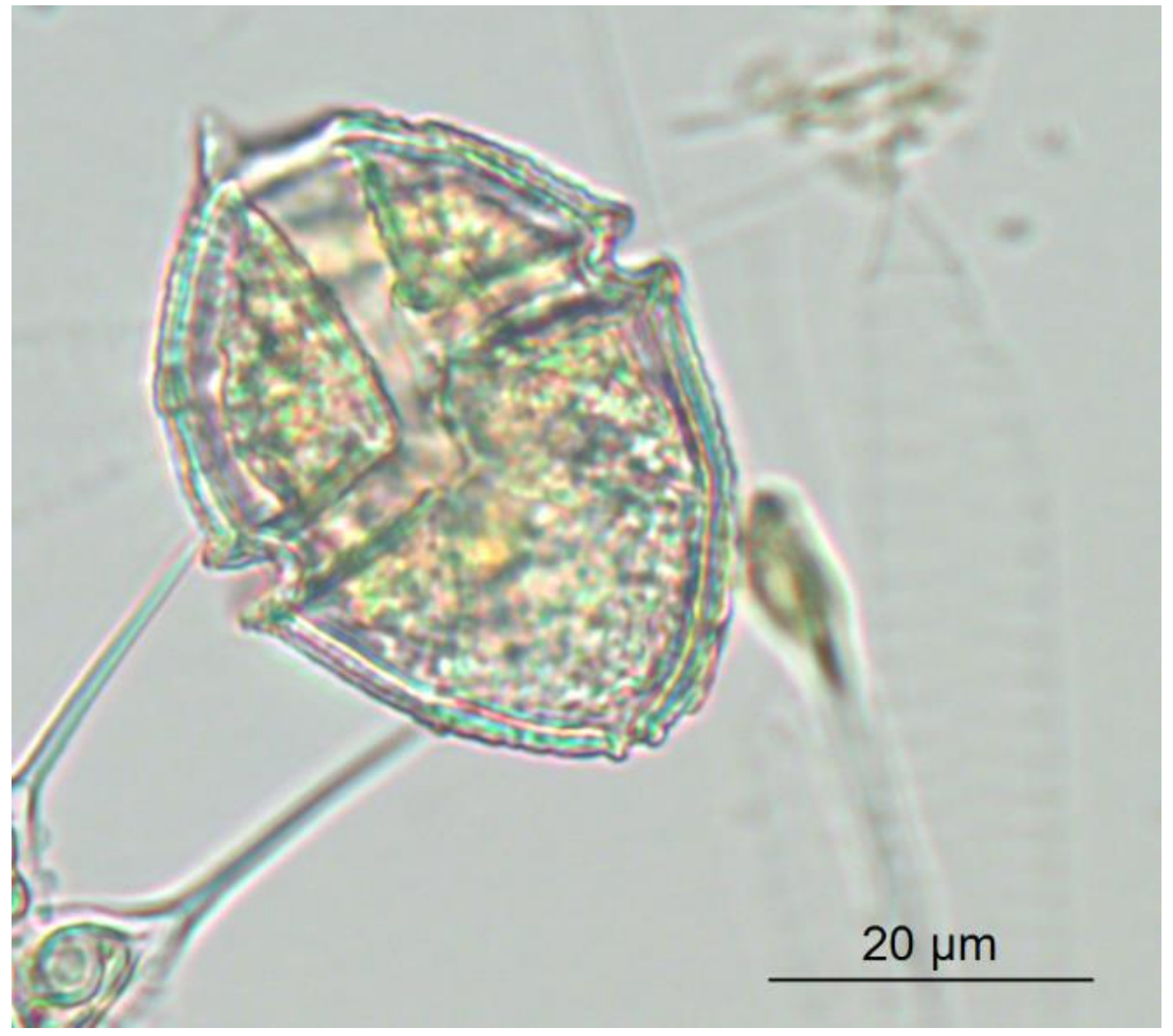


Parvodinium inconspicuum (Lemmermann) Carty, 2008
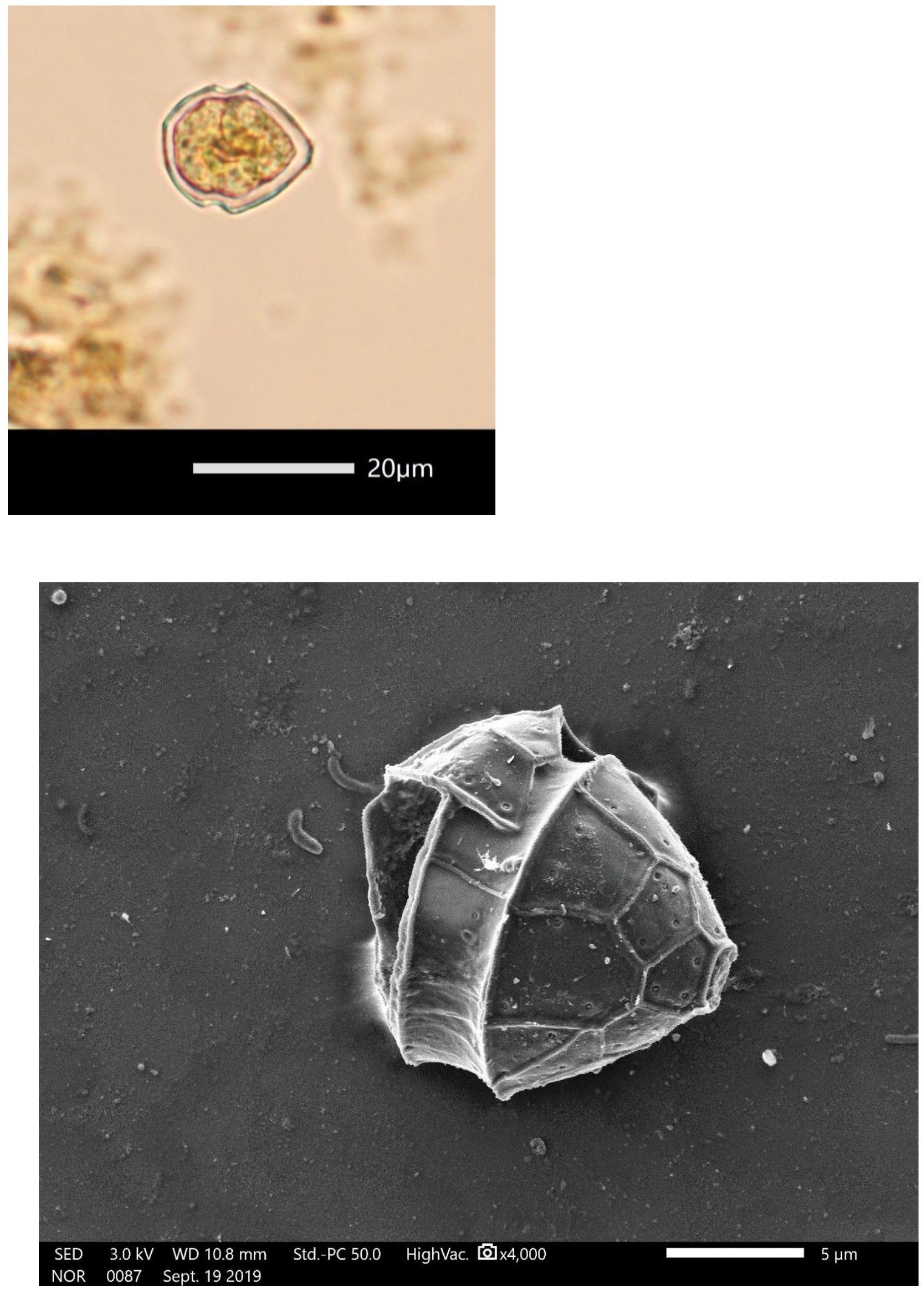
Peridinium cf. bipes $\mathrm{F}$. Stein, 1883
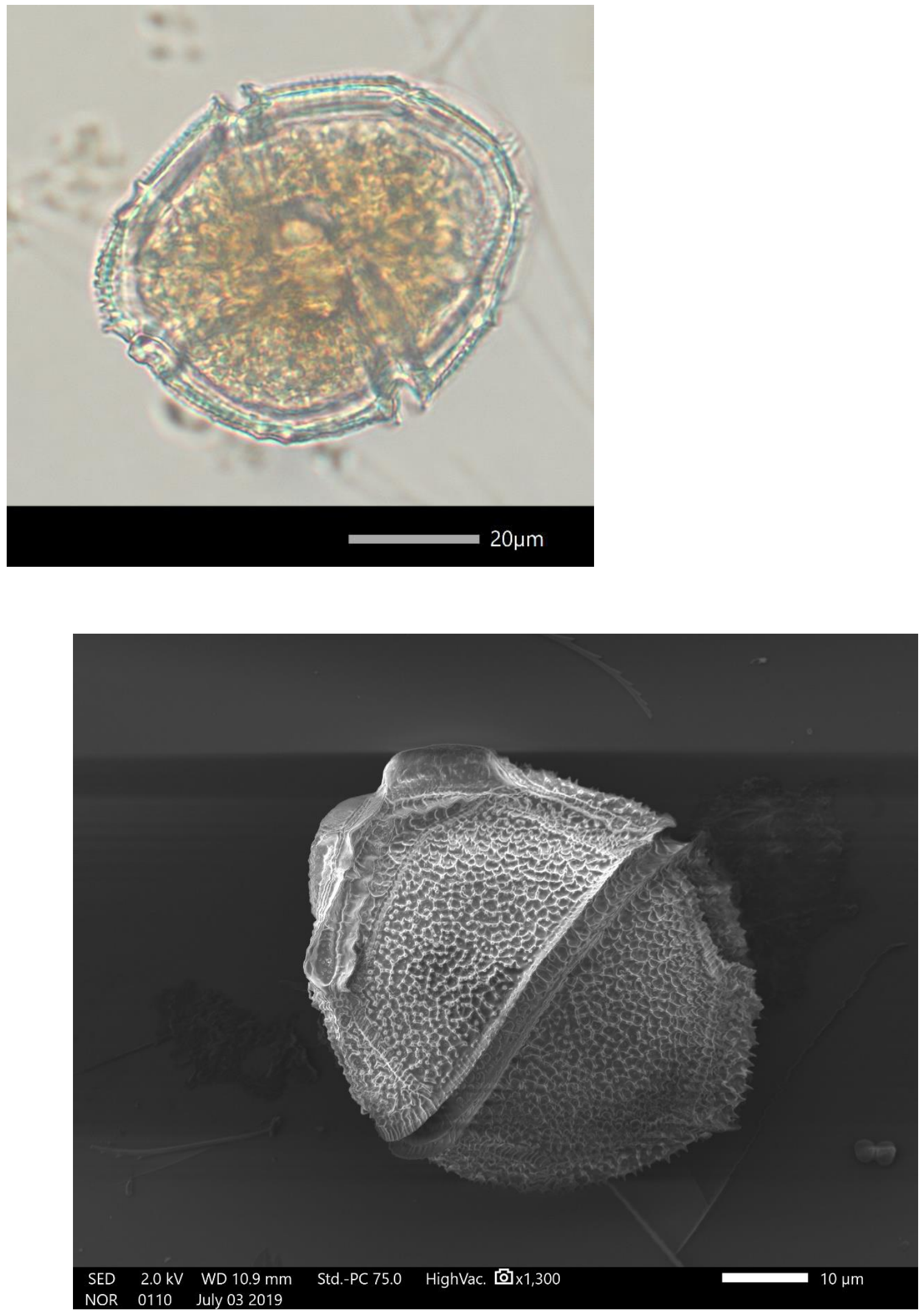
Peridinium sp. 1 Ehrenberg, 1830
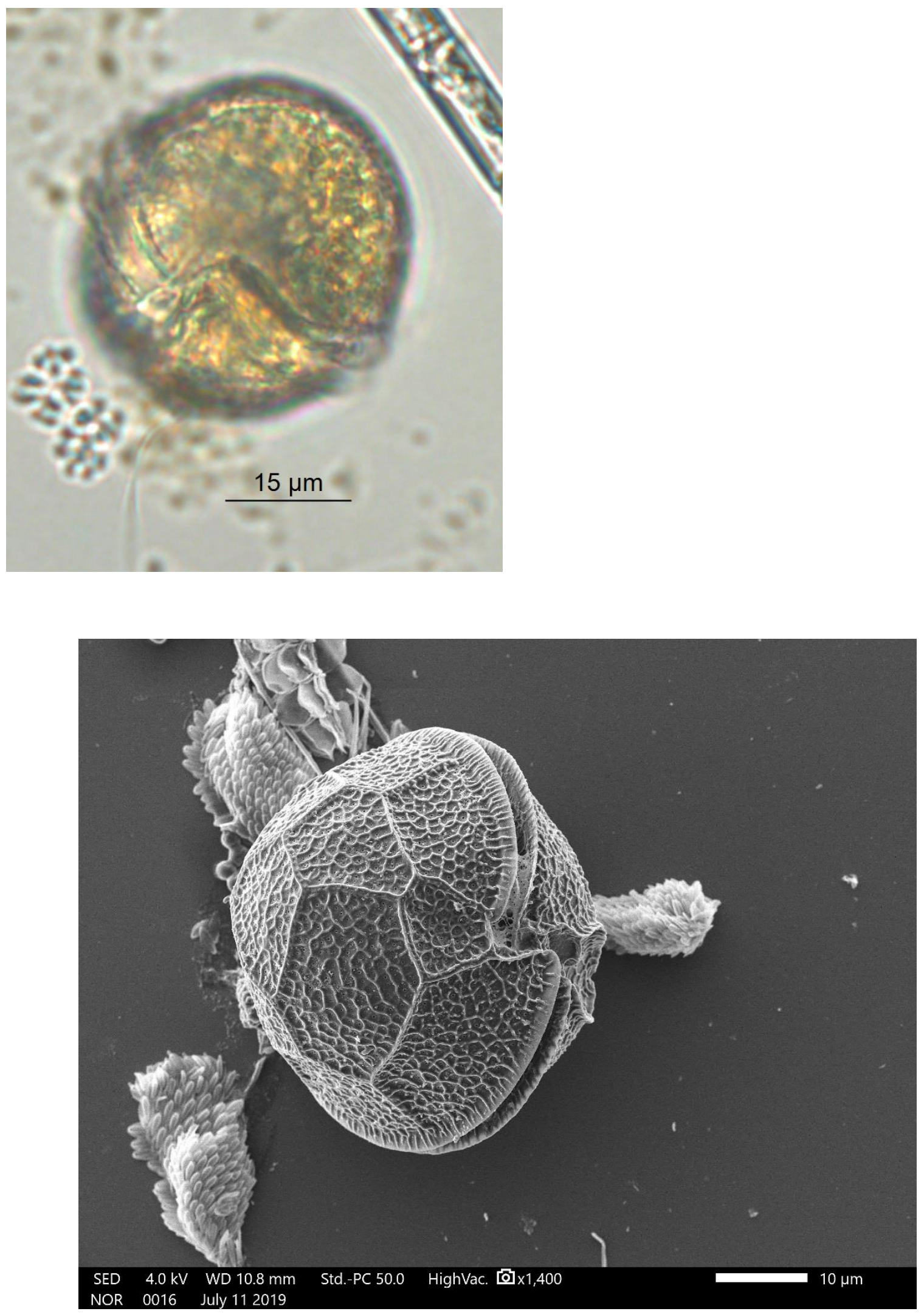
Peridinium sp. 2 Ehrenberg, 1830

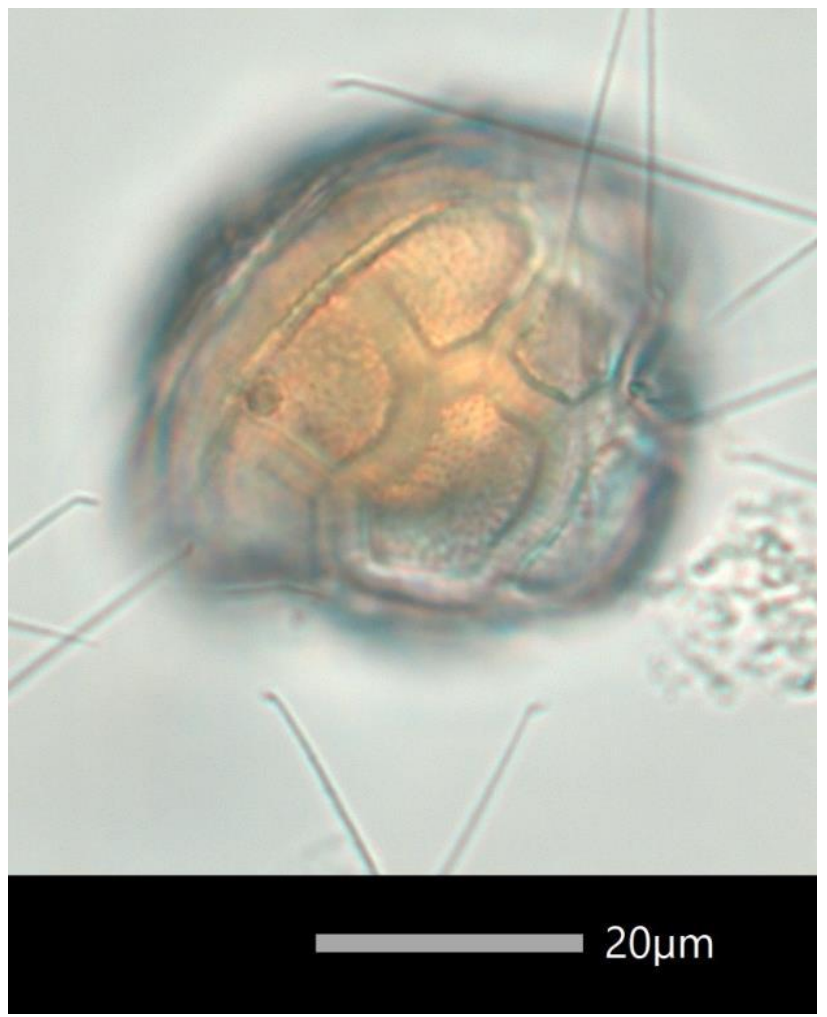

8. Cyanobacteria

Aphanothece spp. C. Nägeli, 1849

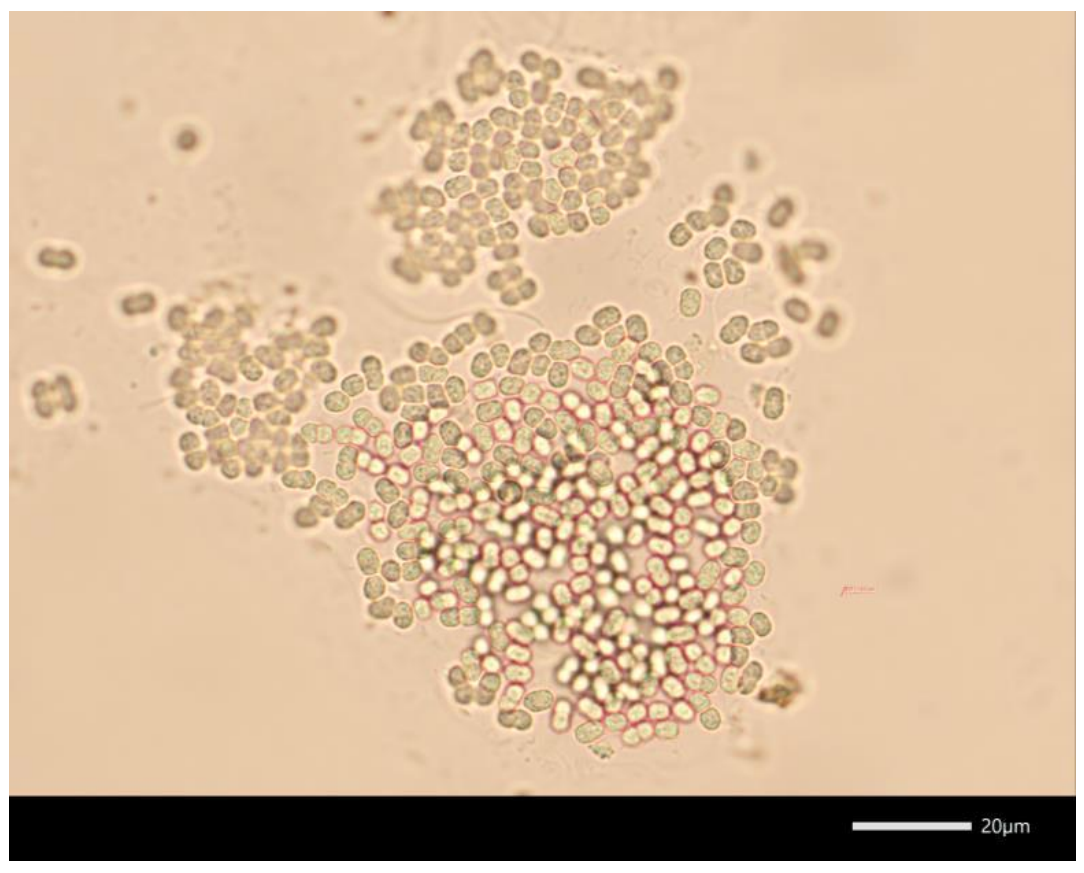


Asterocapsa cf. nidulans (N.L. Gardner) Komárek \& Komárková-Legnerová, 2006

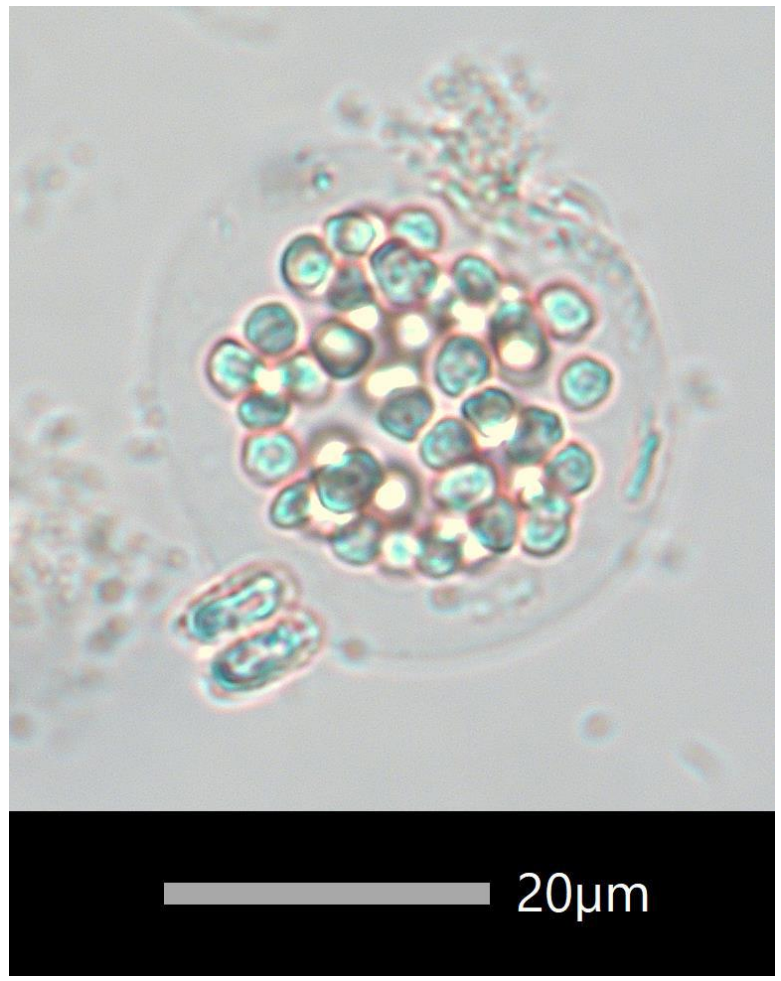

Chroococcus sp. Nägeli, 1849

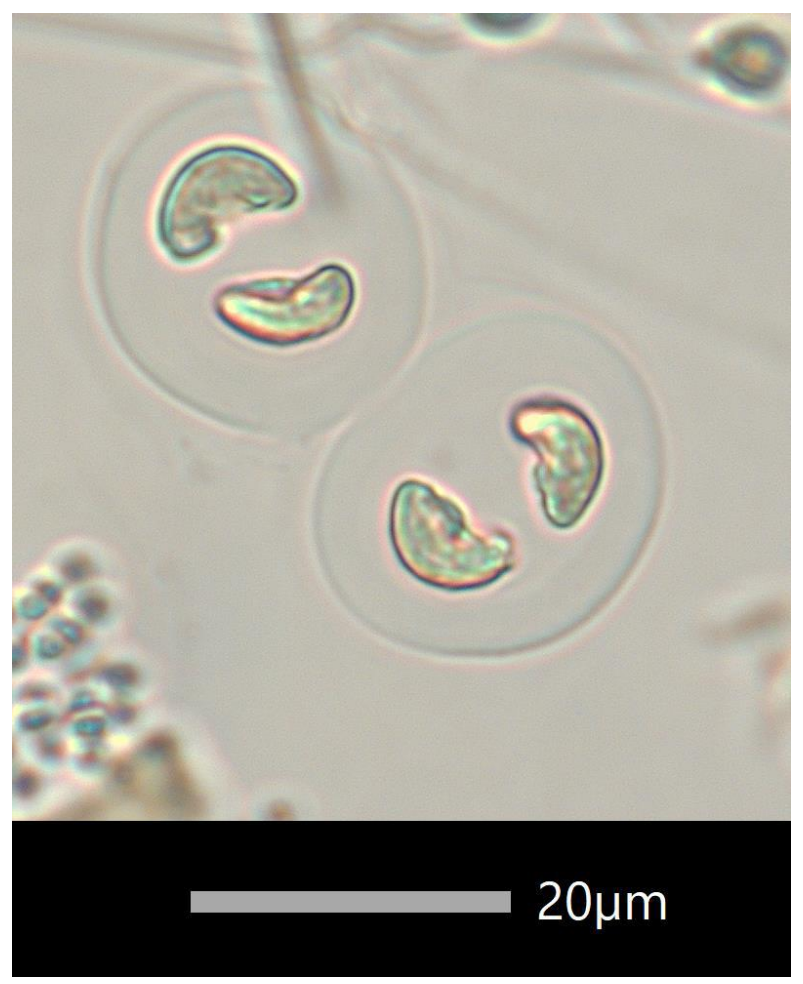


Chroococcus sp. LG Nägeli, 1849

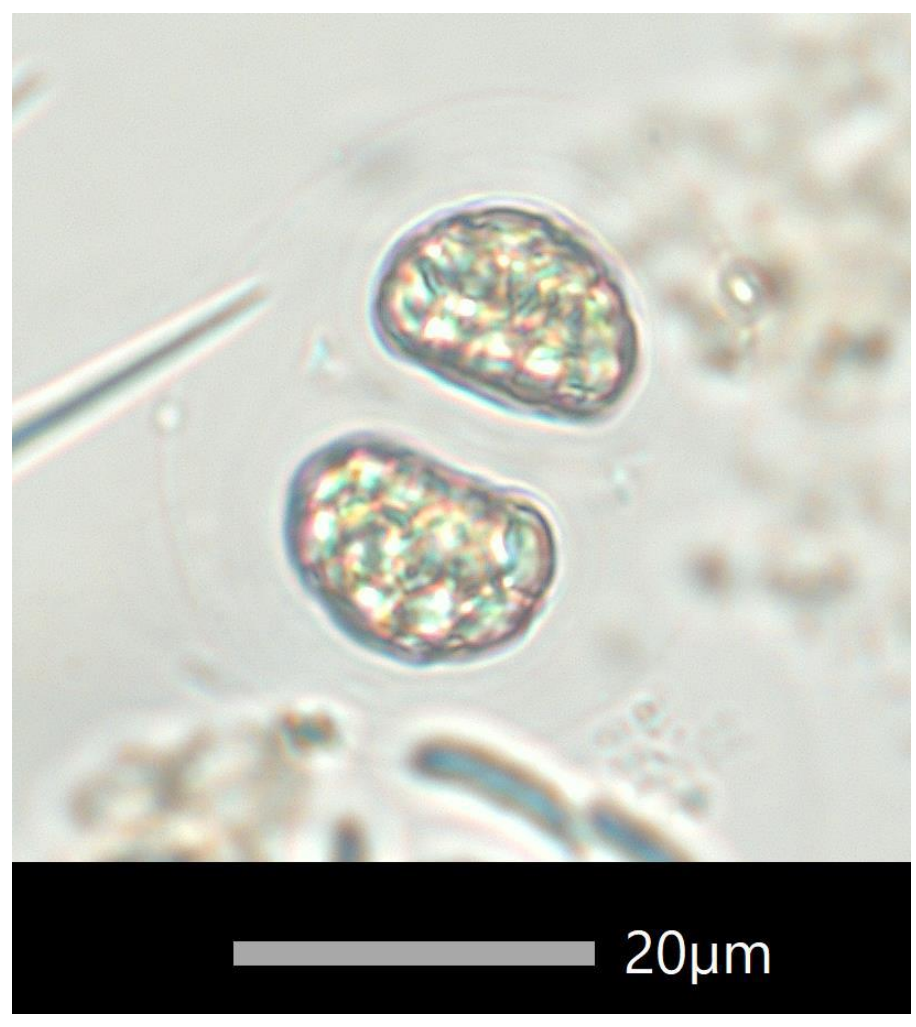

Cyanosarcina sp. cf. L Kovácik, 1988

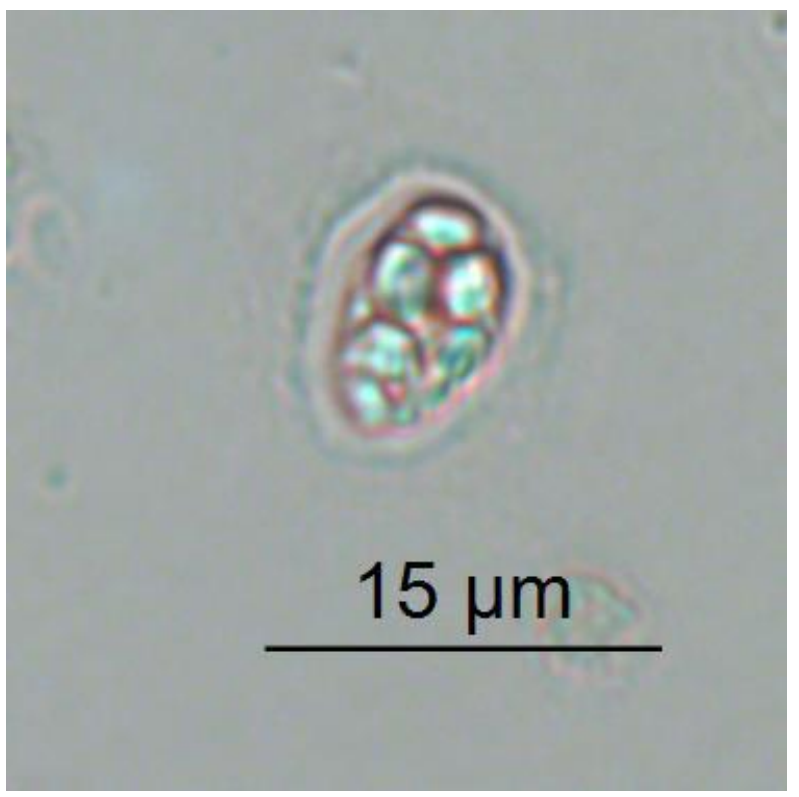


Dolichospermum sp. 1 (Ralfs ex Bornet \& Flahault) P. Wacklin, L. Hoffmann \& J. Komárek, 2009

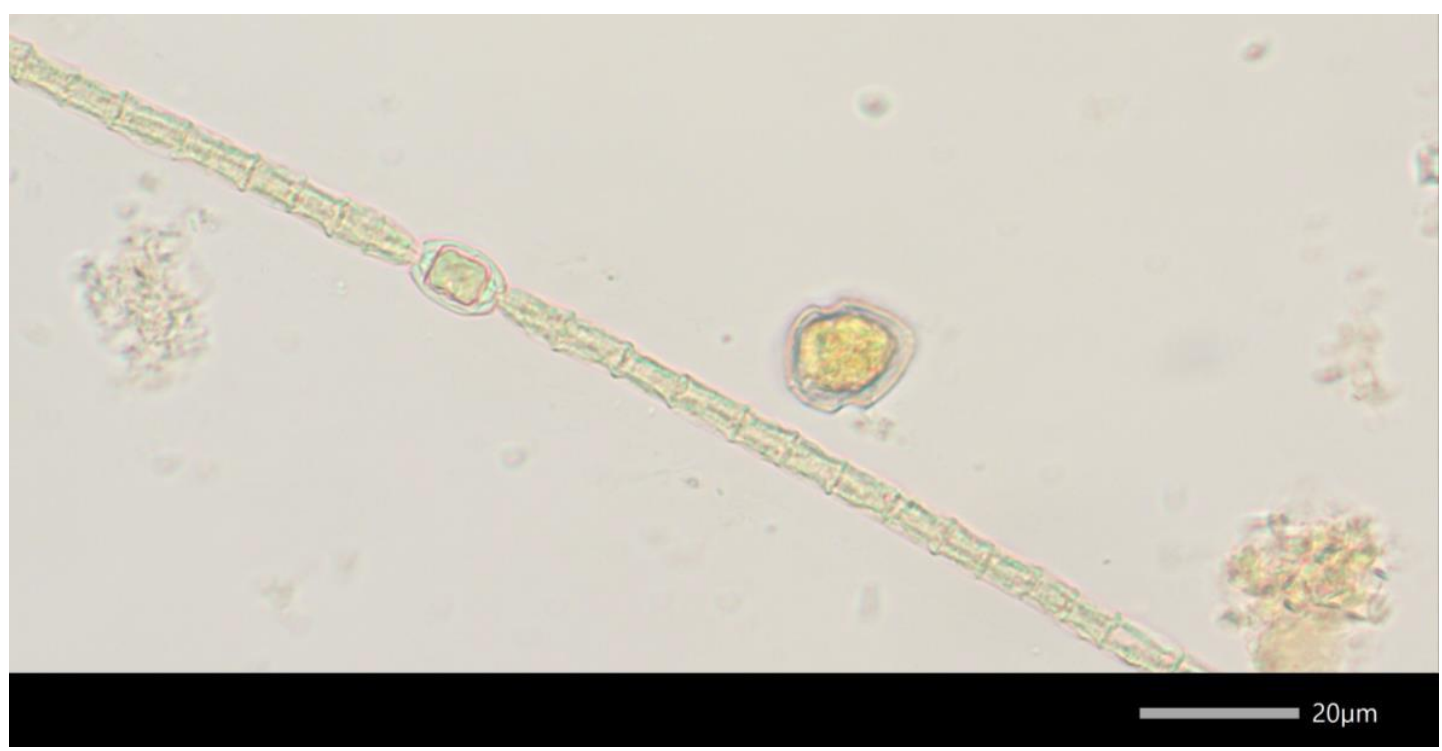

Dolichospermum sp. 2 cf. (Ralfs ex Bornet \& Flahault) P. Wacklin, L. Hoffmann \& J.

Komárek, 2009

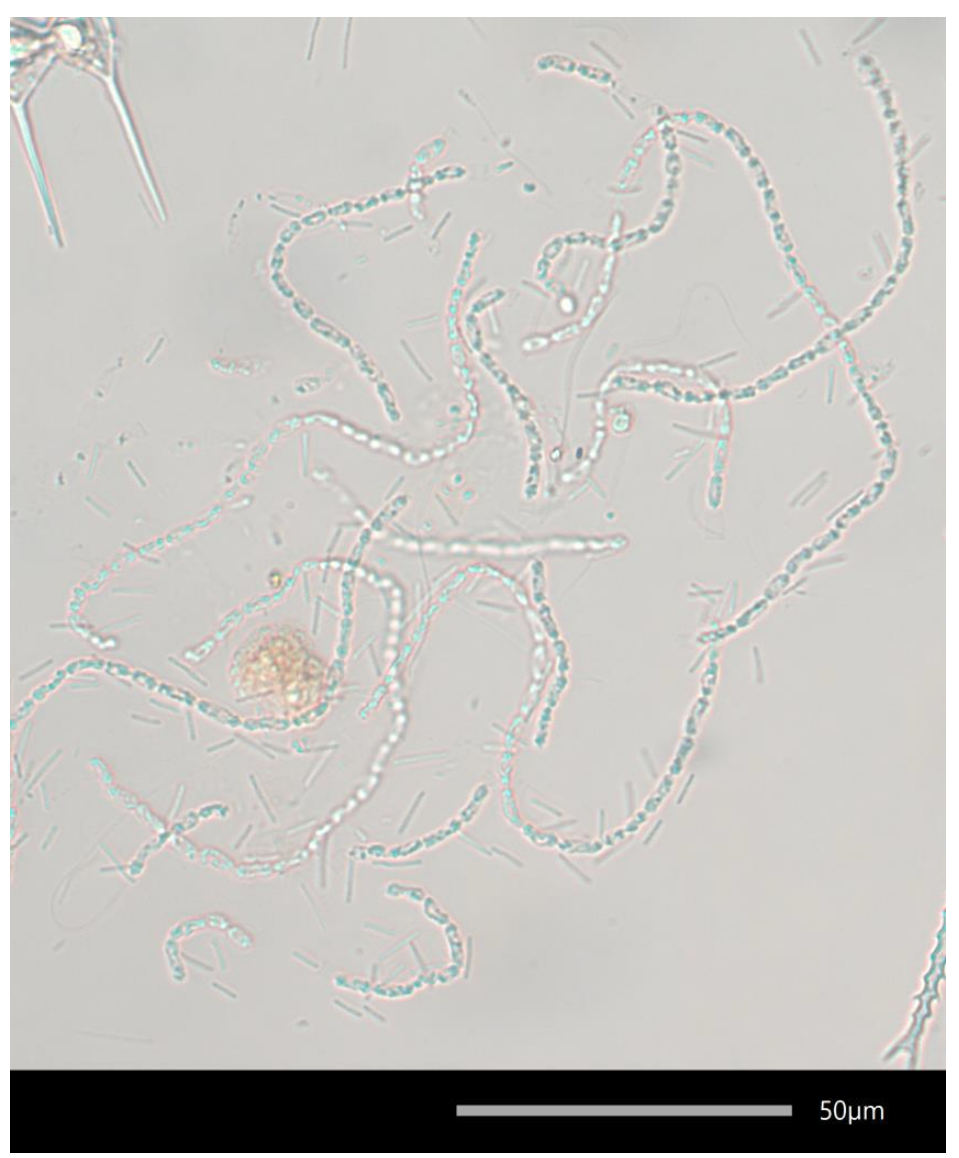


Dolichospermum sp. 3 (Ralfs ex Bornet \& Flahault) P. Wacklin, L. Hoffmann \& J. Komárek, 2009

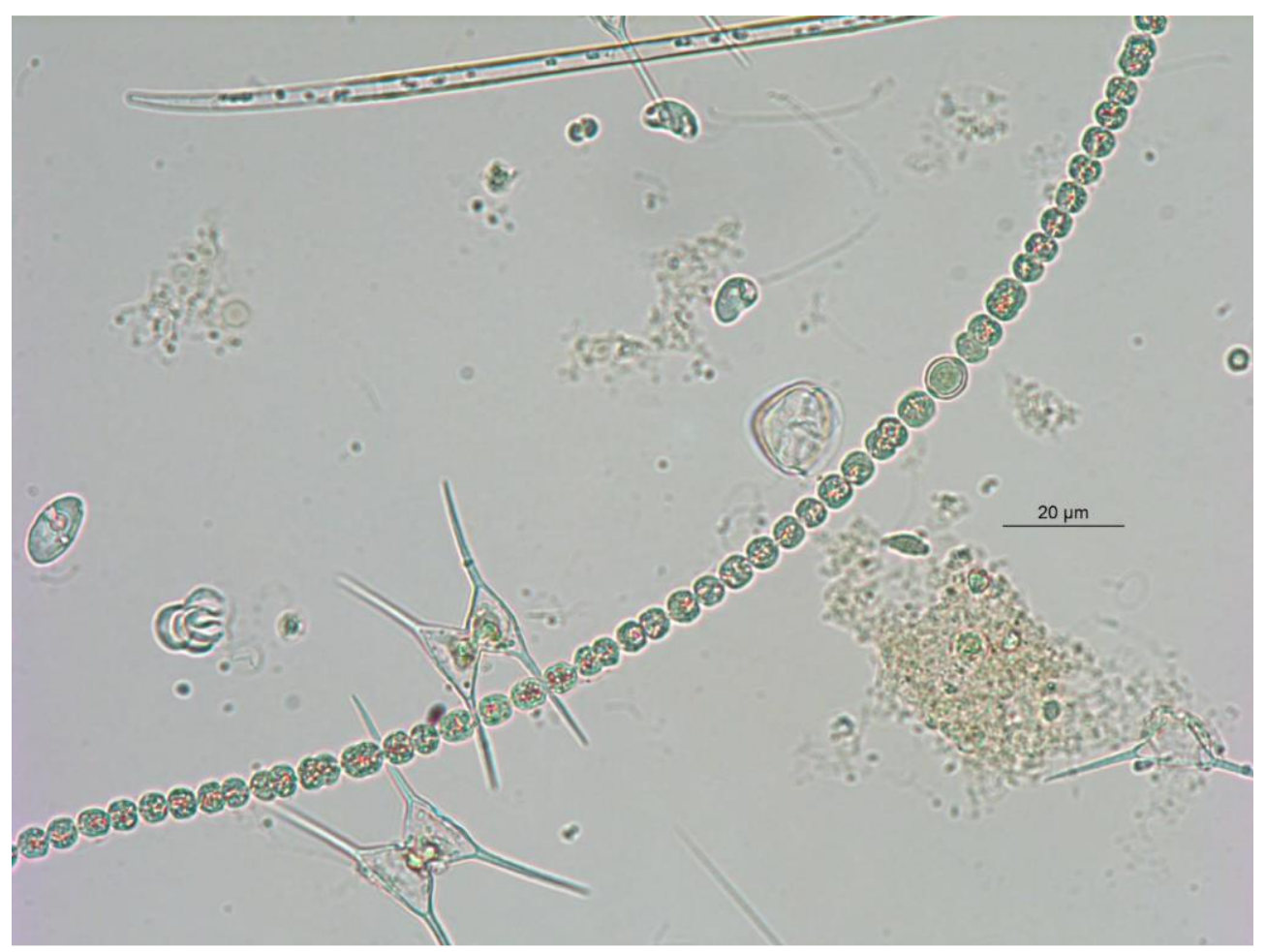

Eucapsis spp. F.E. Clements \& H.L. Shantz, 1909

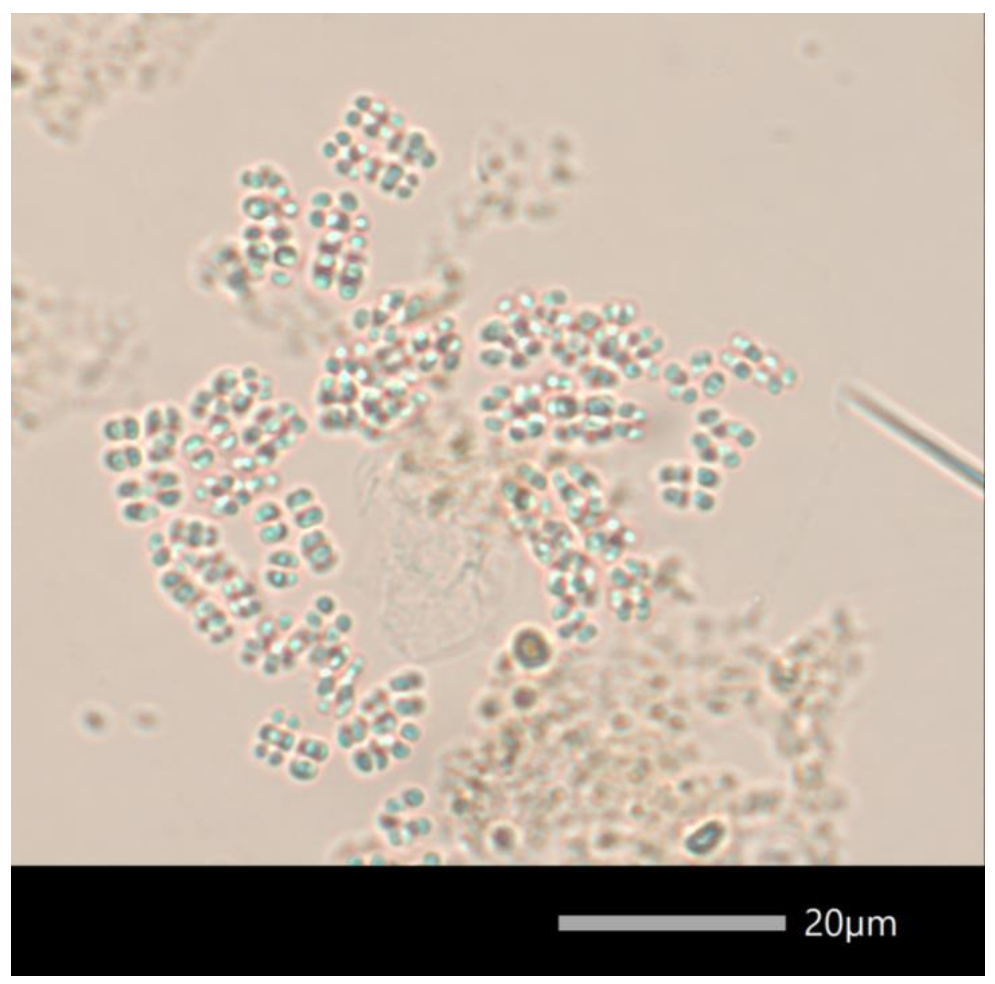


Geitlerinema cf. splendidum (Greville ex Gomont) Anagnostidis, 1989

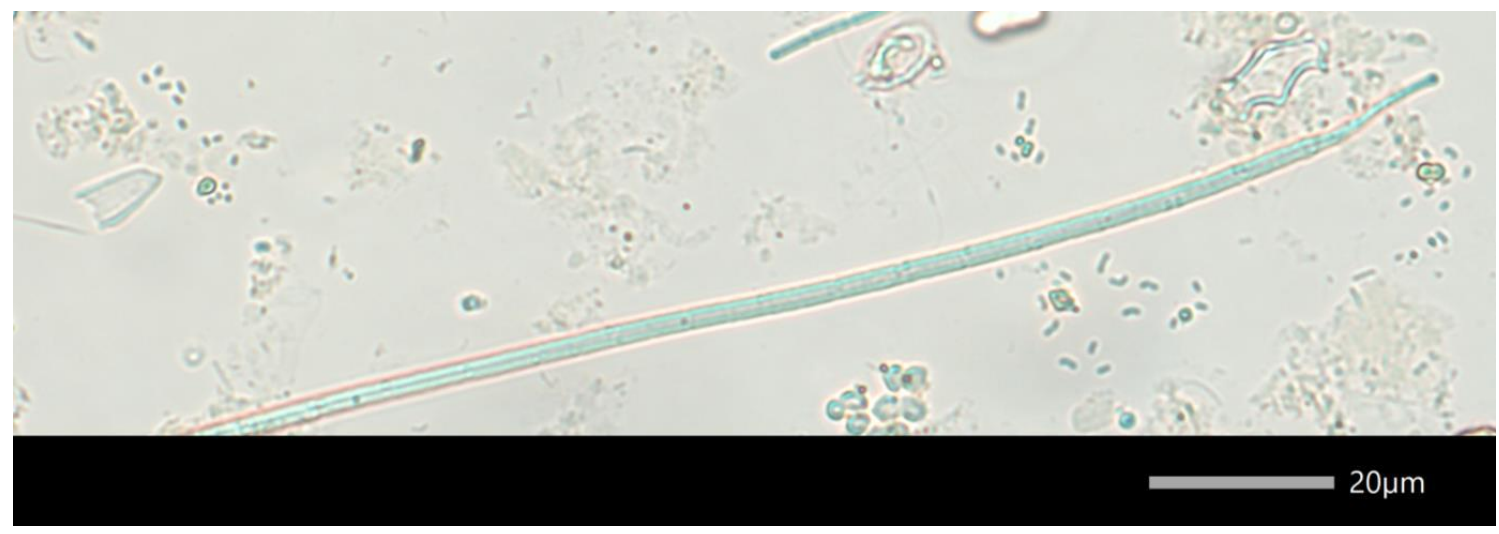

Gloeocapsa sp. 1 cf. Kützing, 1843

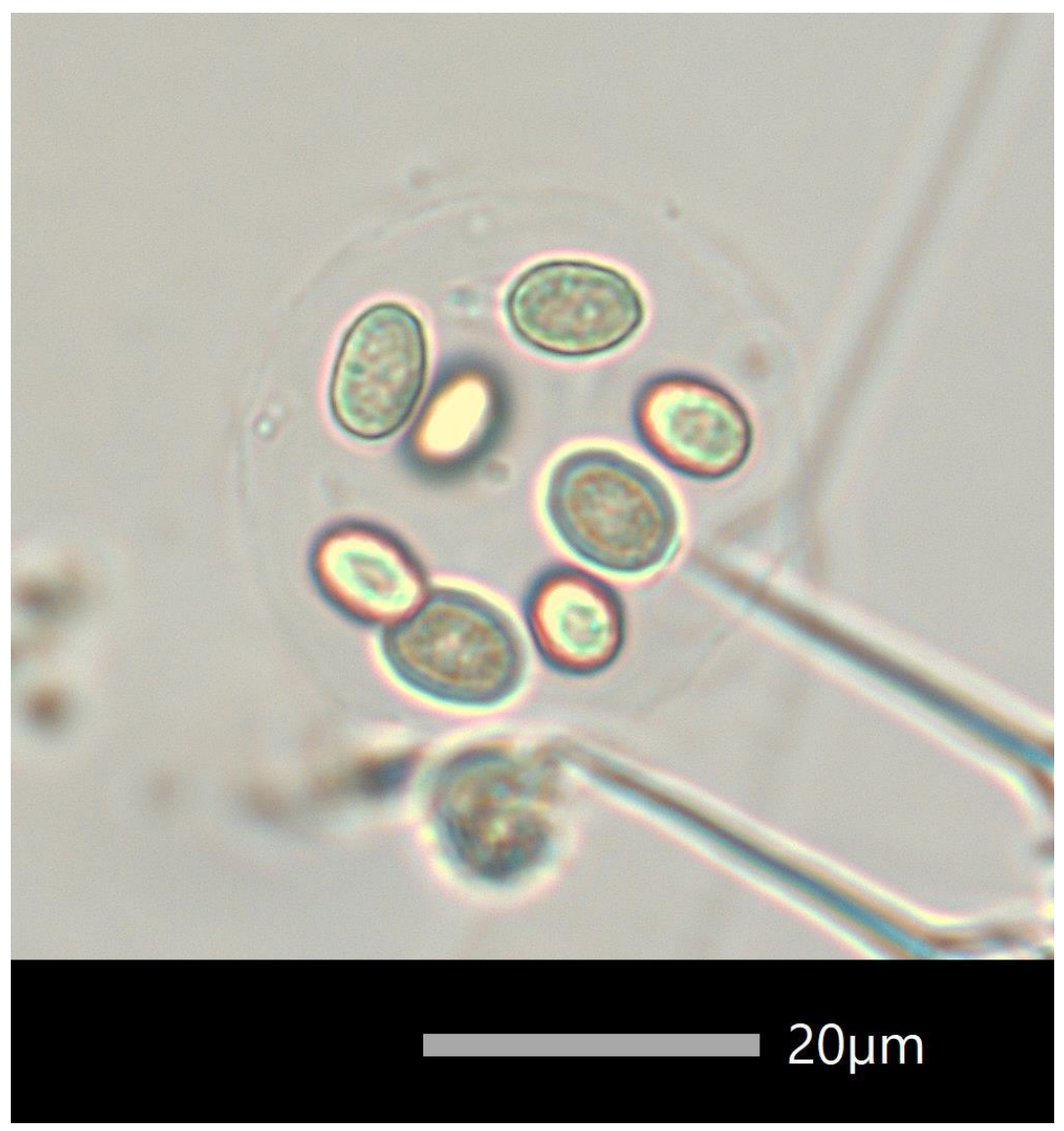


Gloeocapsa sp. 2 cf. Kützing, 1843

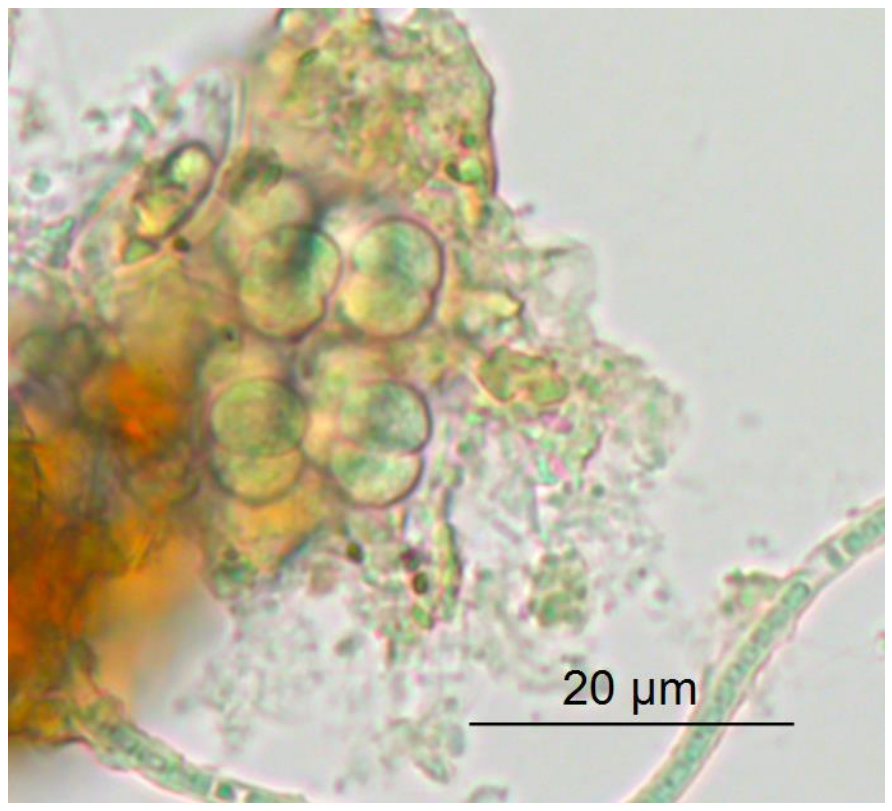

Gloeocapsa cf. novacekii Komárek

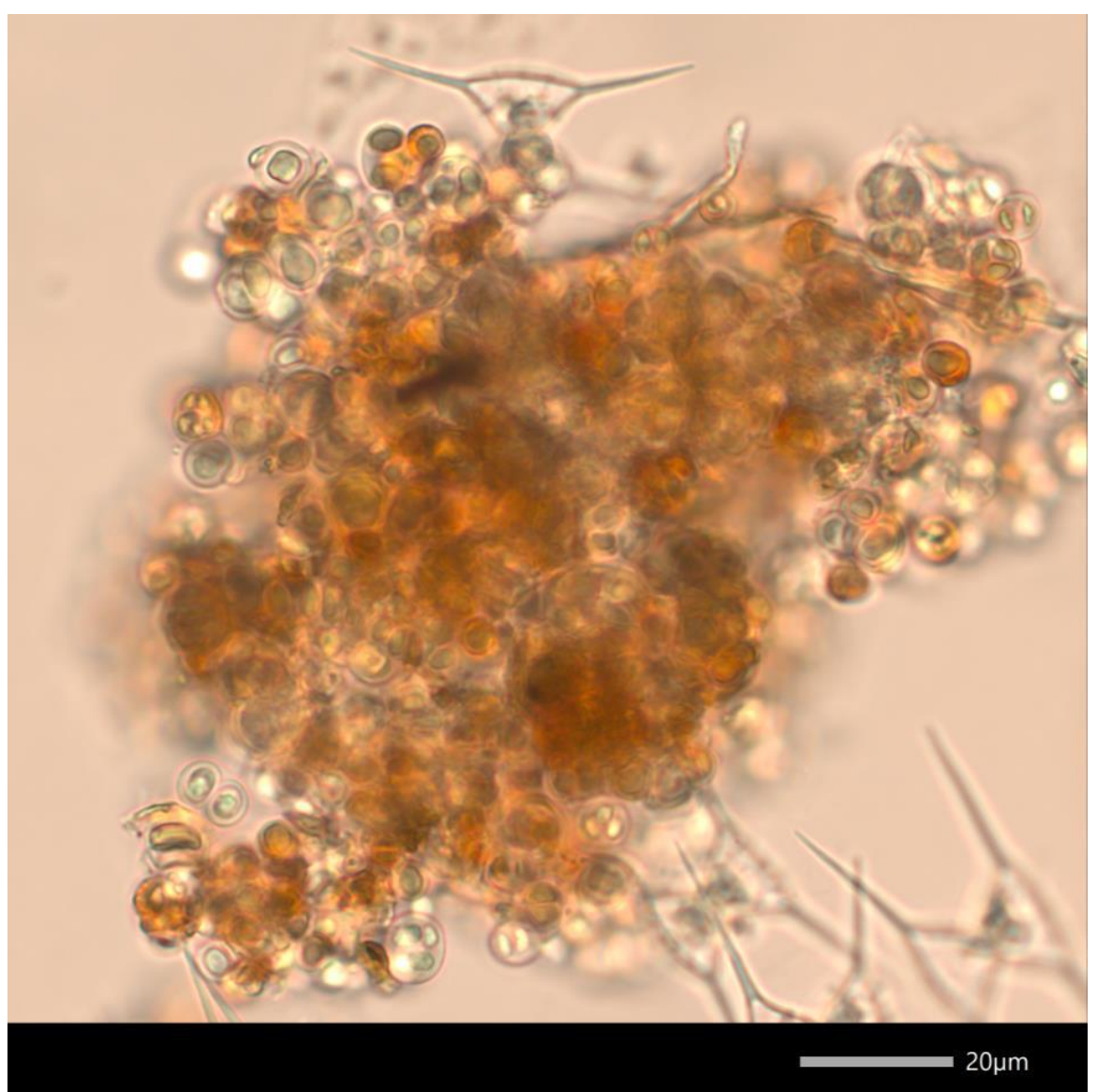


Gloeocapsopsis cf. dvorakii (Novácek) Komárek \& Anagnostidis ex Komárek, 1993

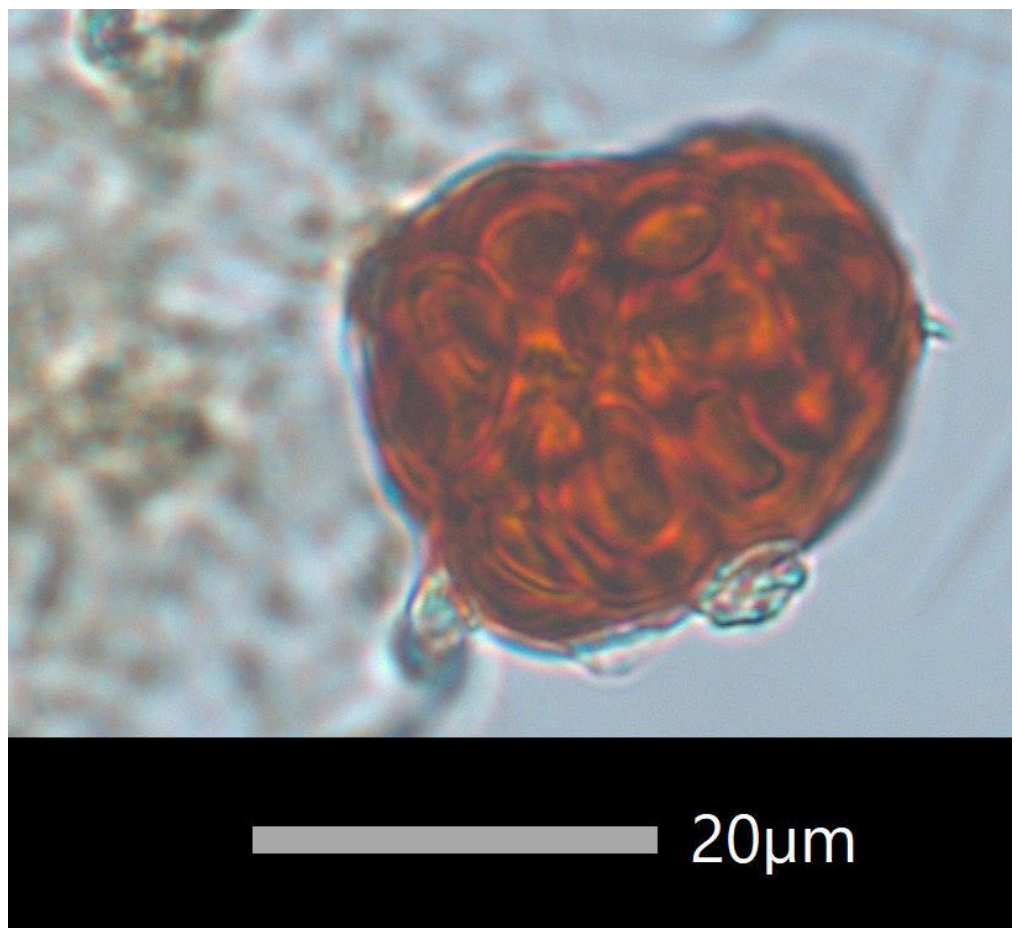

Limnococcus cf. limneticus (Lemmermann) Komárková, Jezberová, O. Komárek, \& Zapomelová, 2010

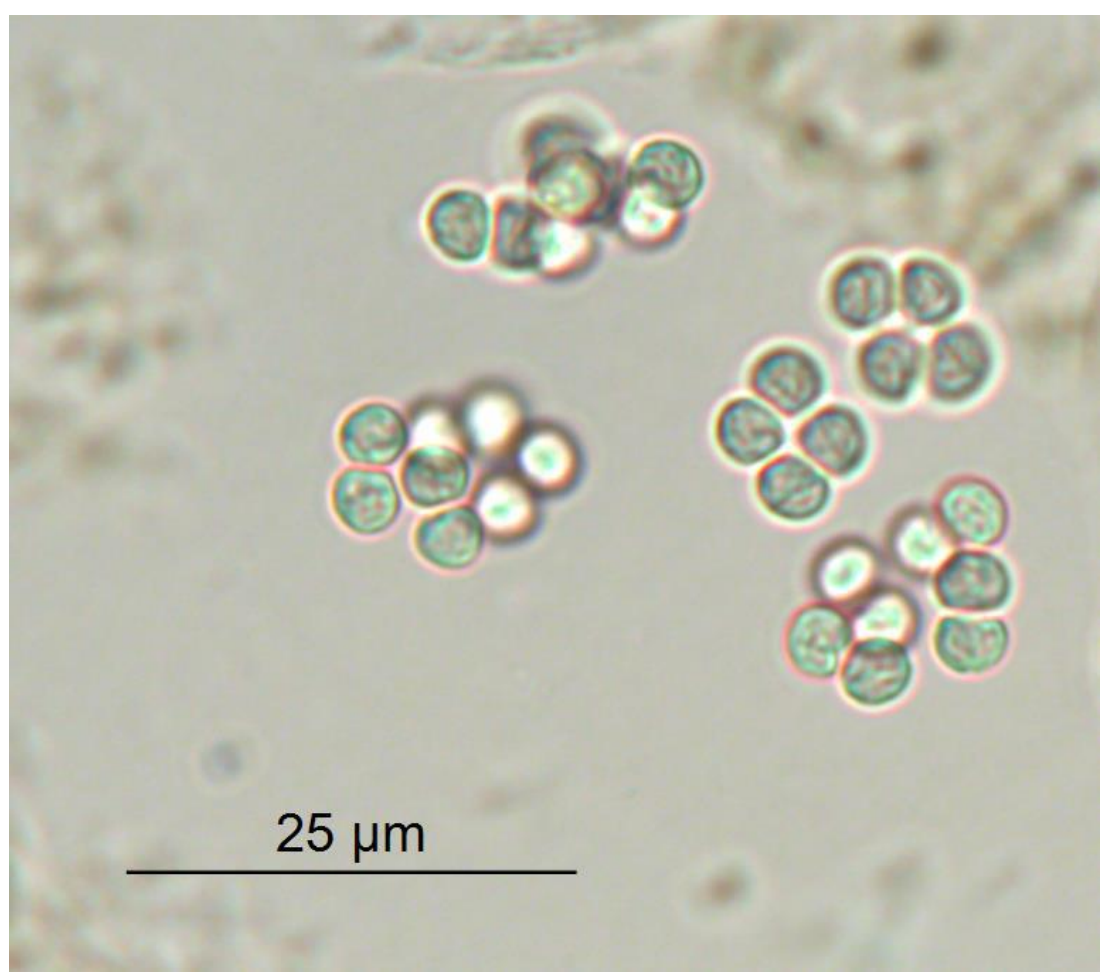


Limnococcus sp. 1 (Lemmermann) Komárková, Jezberová, O. Komárek, \& Zapomelová, 2010

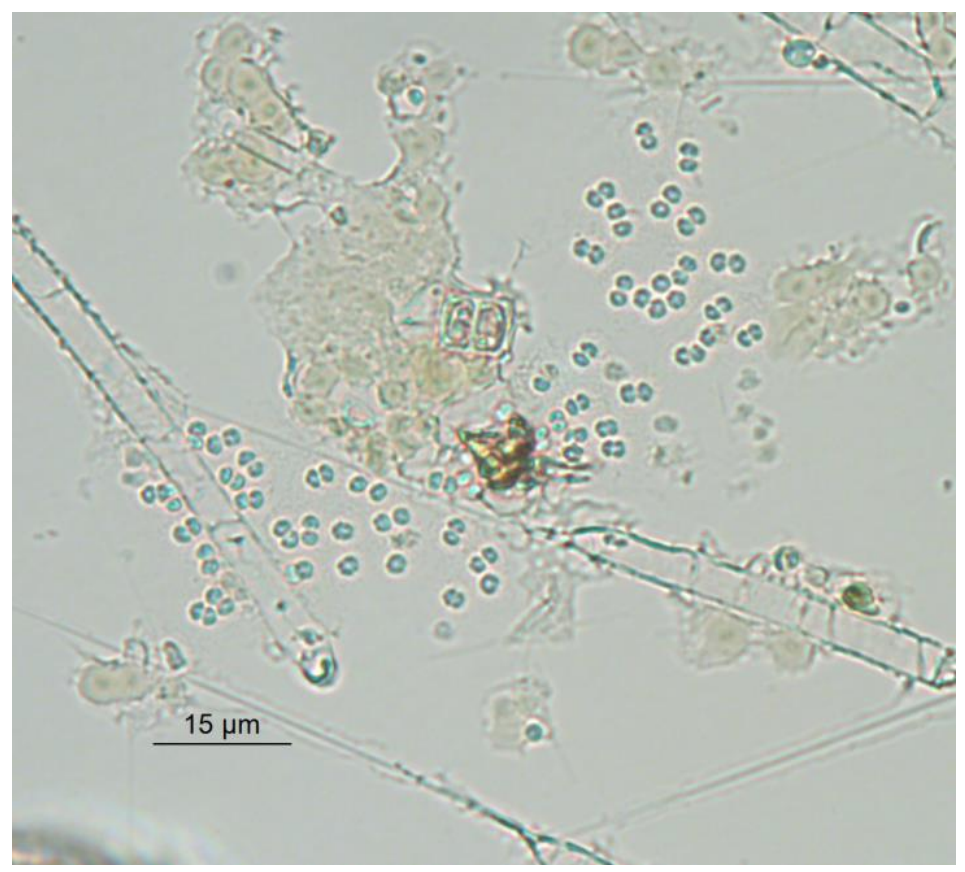

Limnothrix sp. 1 M.-E. Meffert, 1988

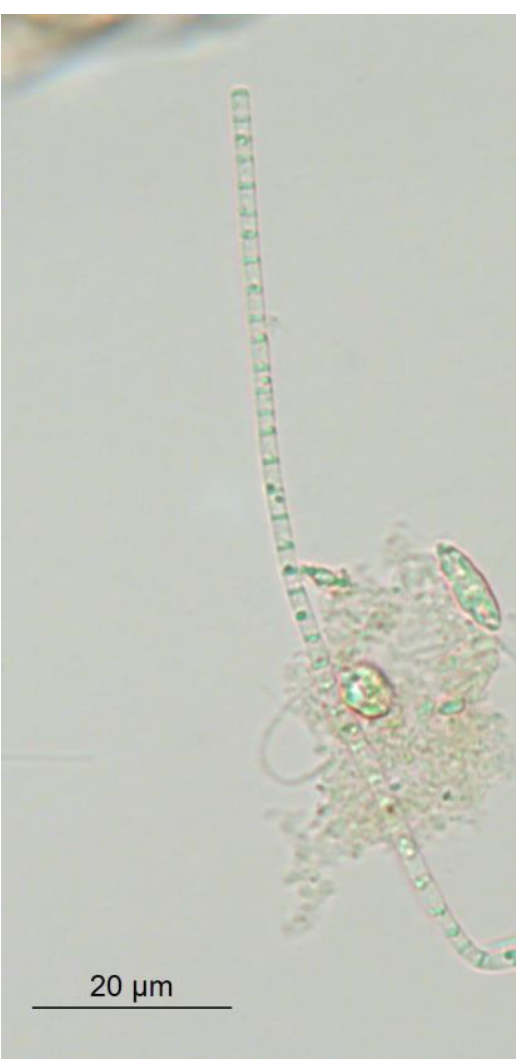


Limnothrix sp. 2 M.-E. Meffert, 1988

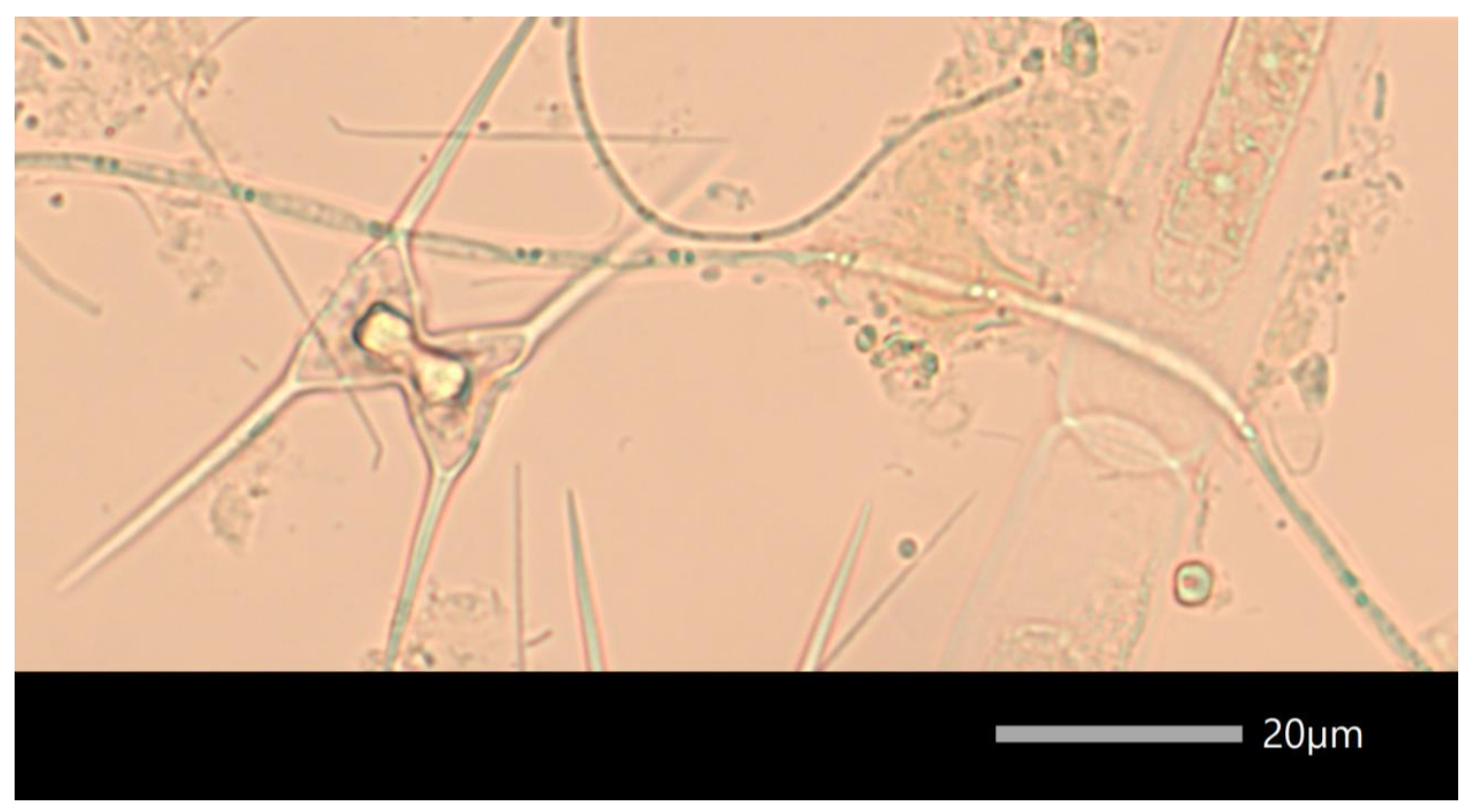

Merismopedia spp. Meyen, 1839

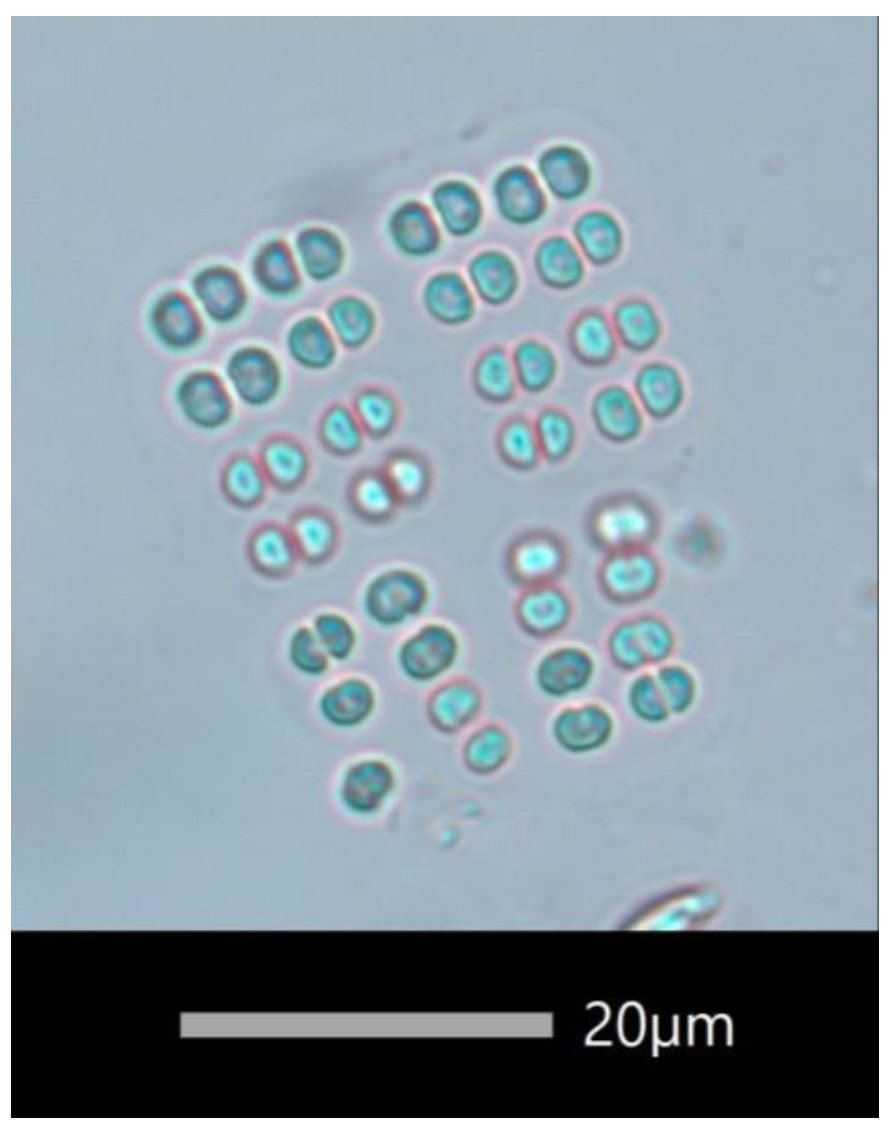


Oscillatoria sp. Vaucher ex Gomont, 1892

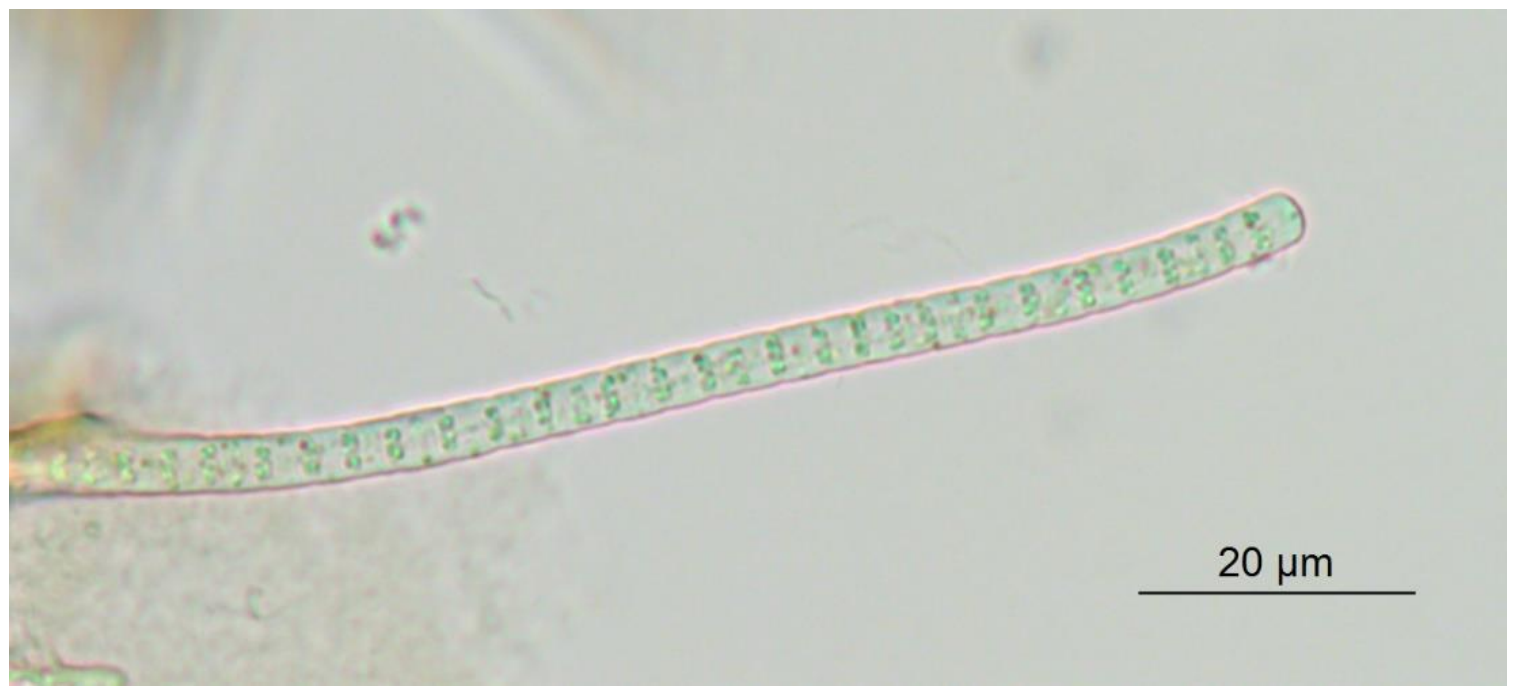

Planktolyngbya sp. Anagnostidis \& Komárek, 1988

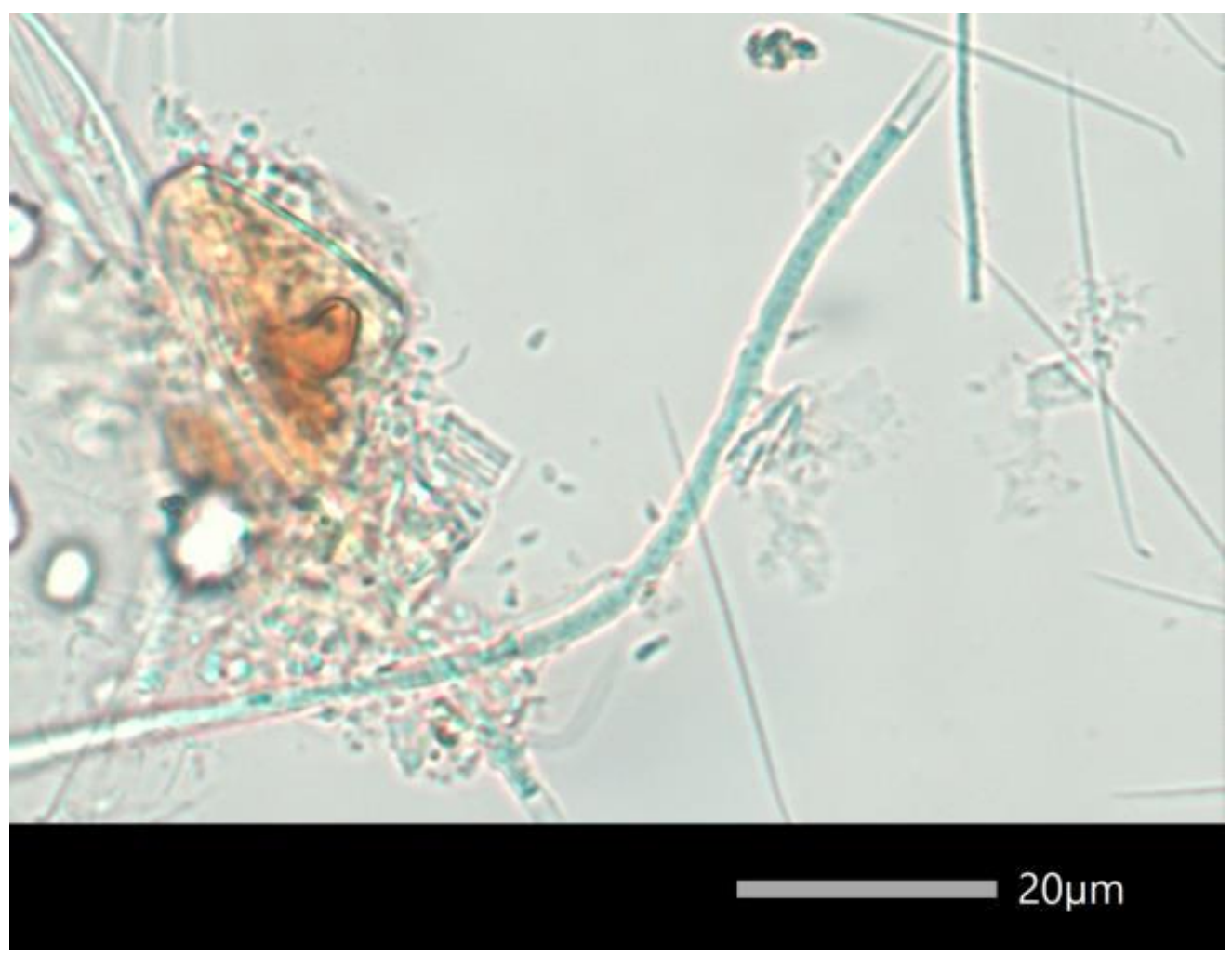


Planktothrix sp. K. Anagnostidis \& J. Komárek, 1988

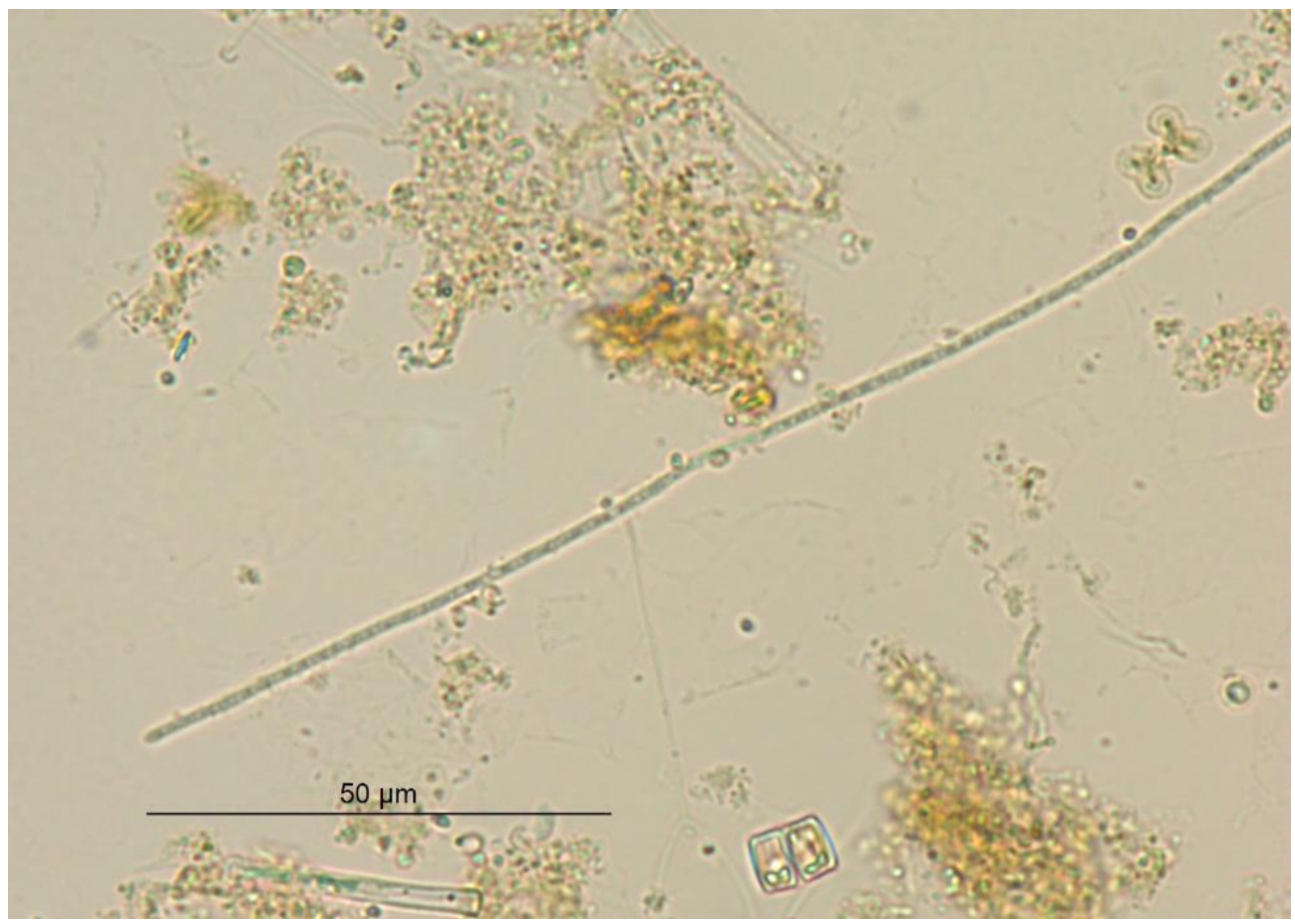

Pseudanabaena sp. 1 cf. Lauterborn, 1915

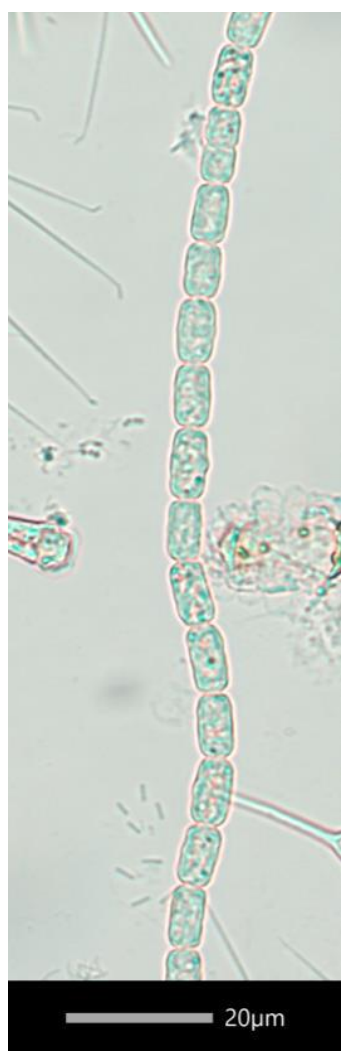


Pseudanabaena sp. 2 cf. Lauterborn, 1915

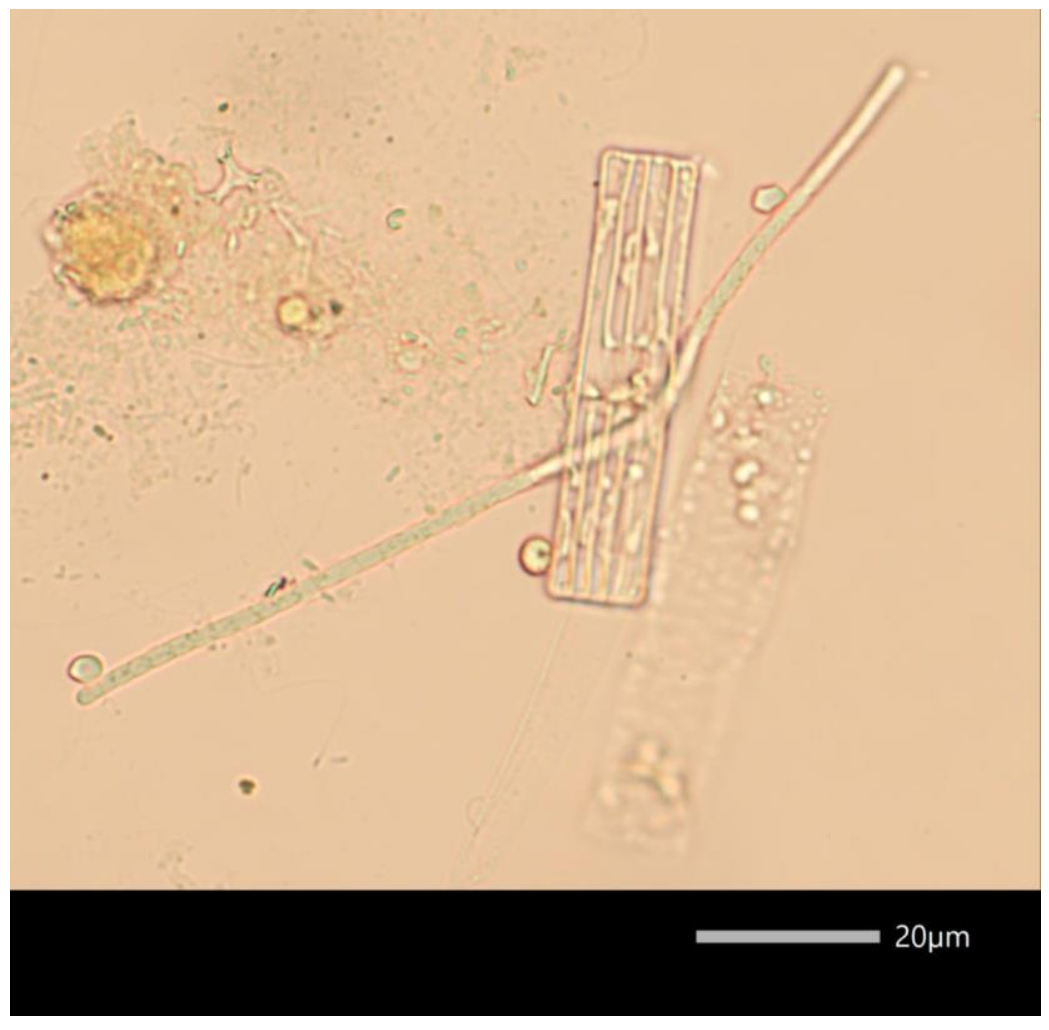

Pseudophormidium sp. (Forti) Anagnostidis \& Komárek, 1988

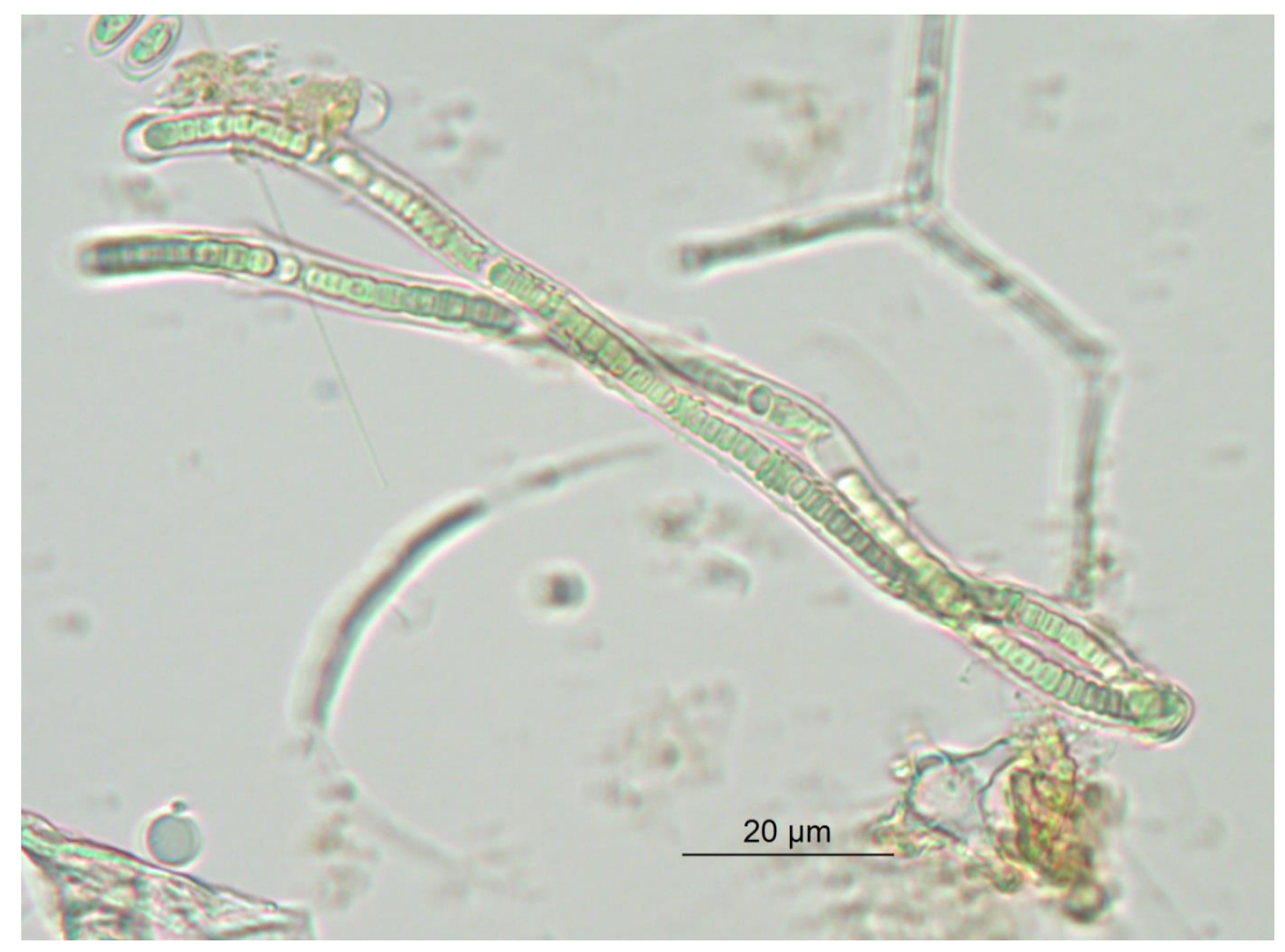


Rhabdoderma sp. 1 Schmidle \& Lauterborn, 1900

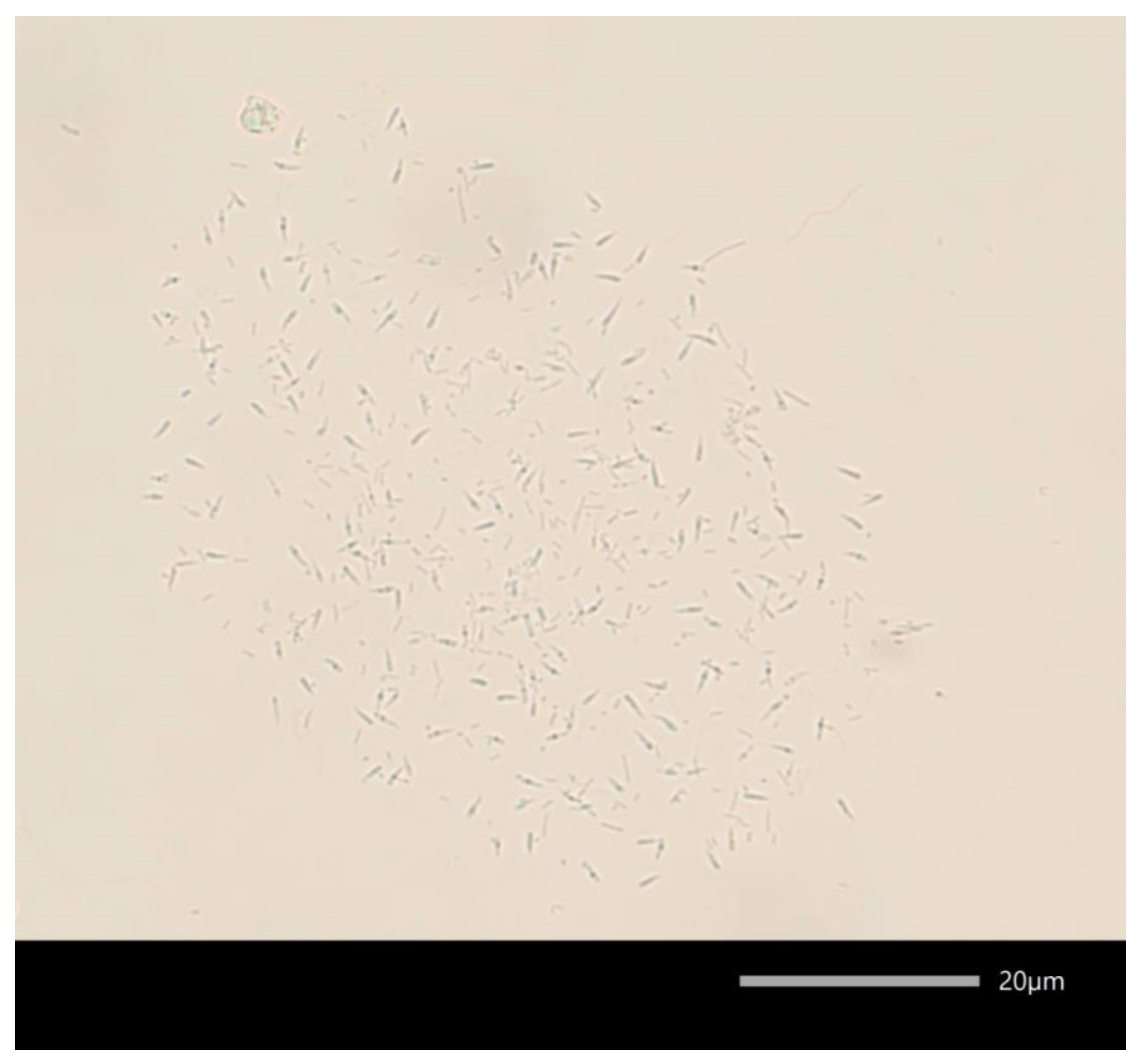

Rhabdoderma sp. 2 Schmidle \& Lauterborn, 1900

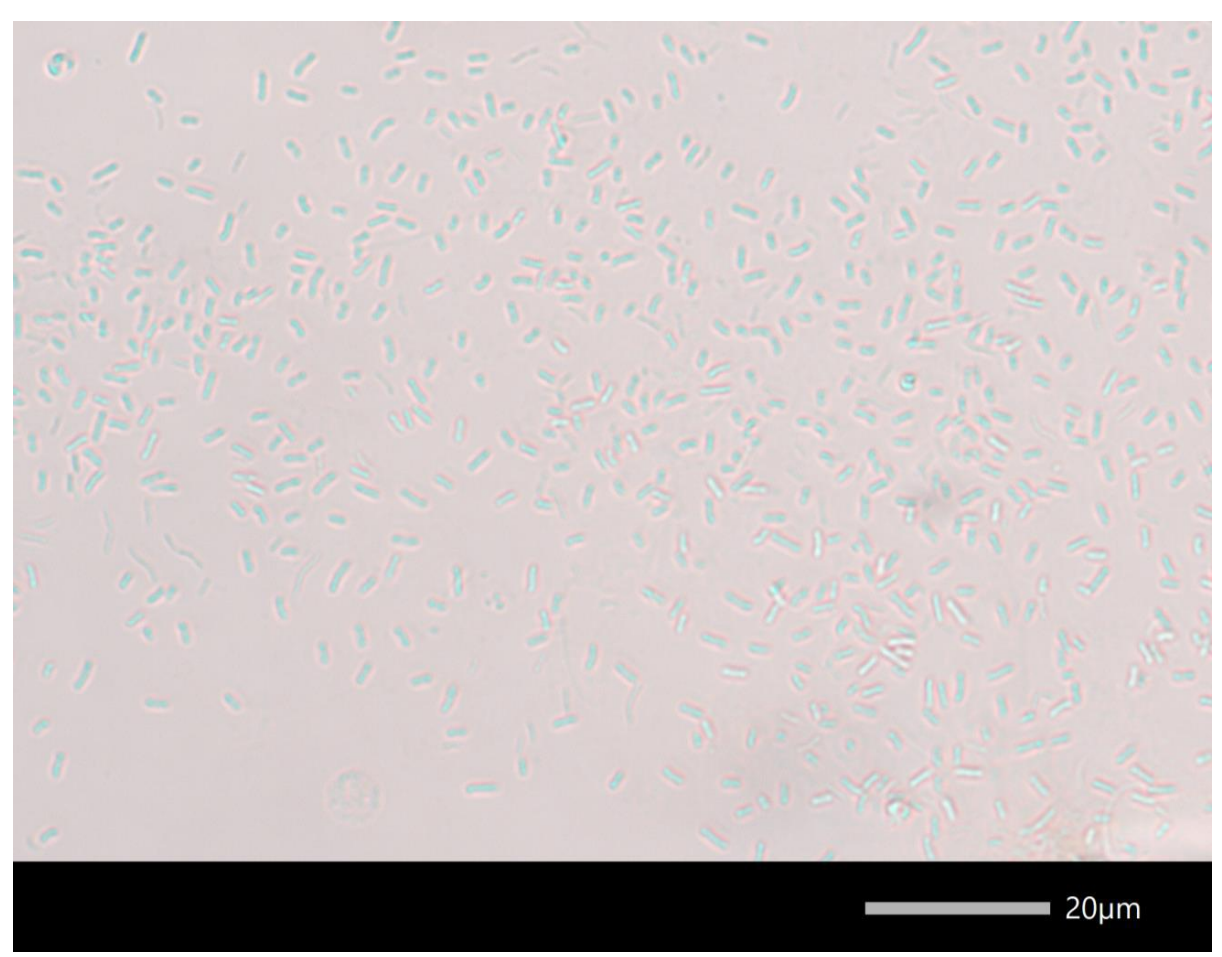


Scytonema sp. 2 cf. C. Agardh ex É. Bornet, \& C. Flahault, 1886

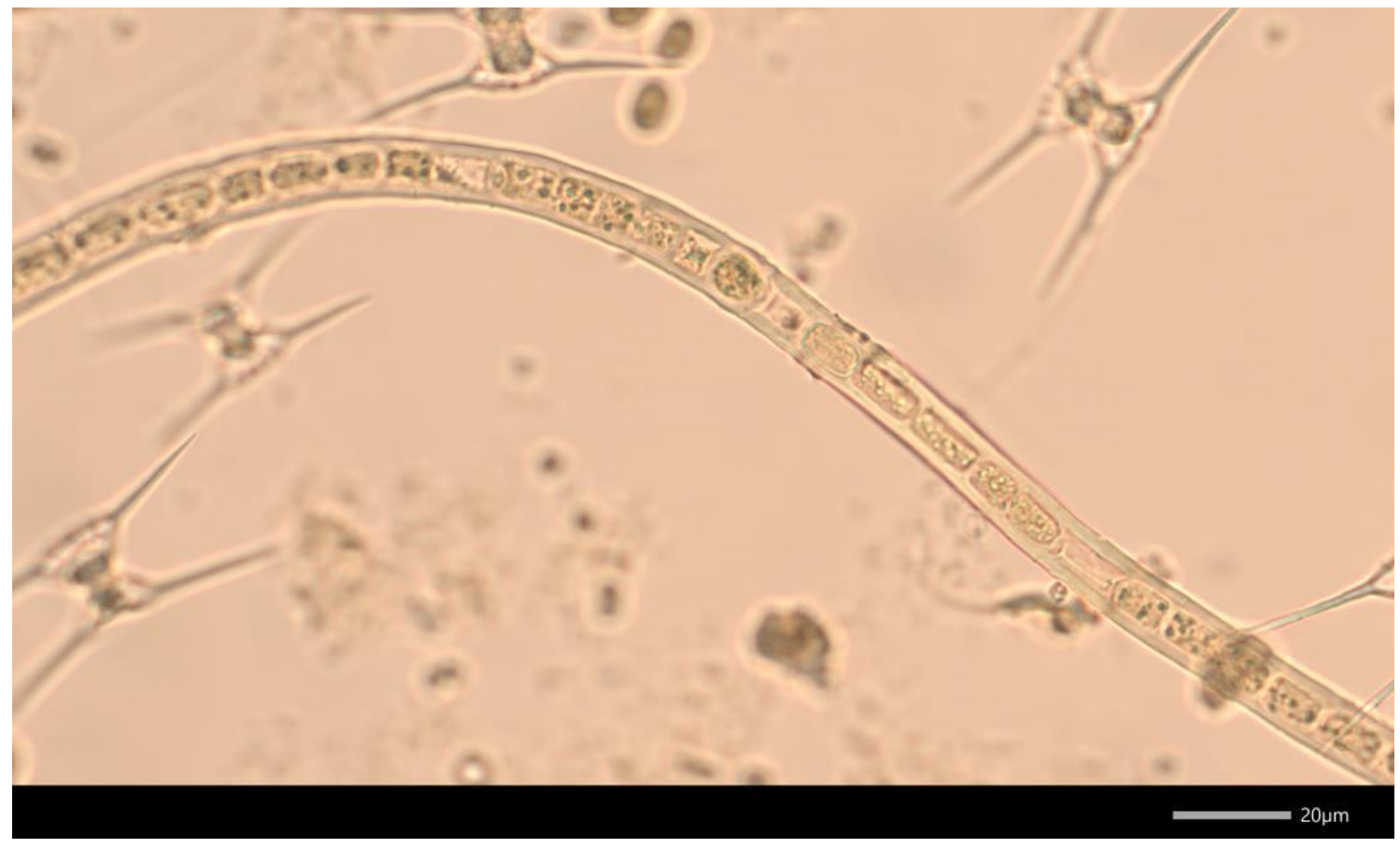

Synechococcus cf. elongatus (Nägeli) Nägeli, 1849

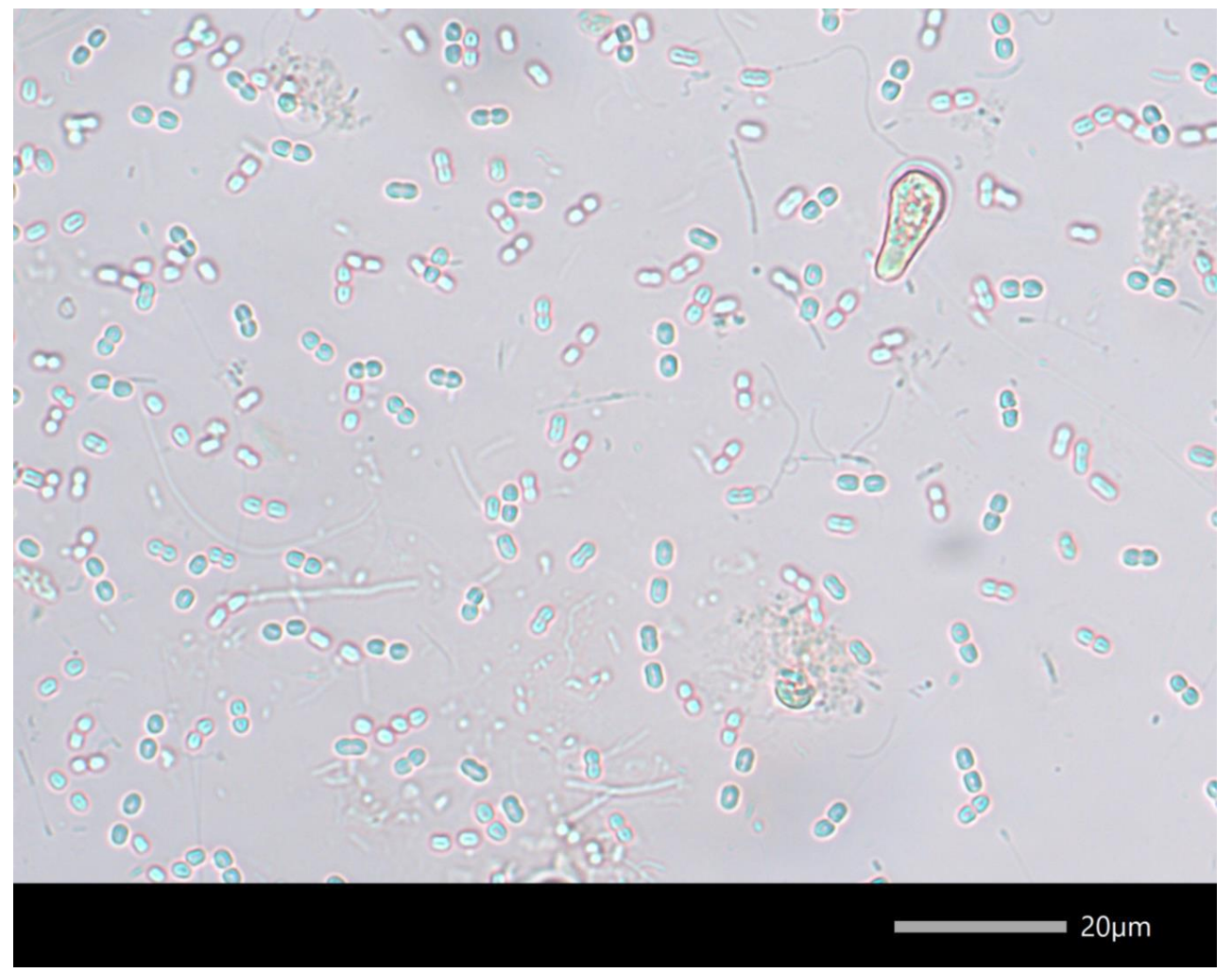




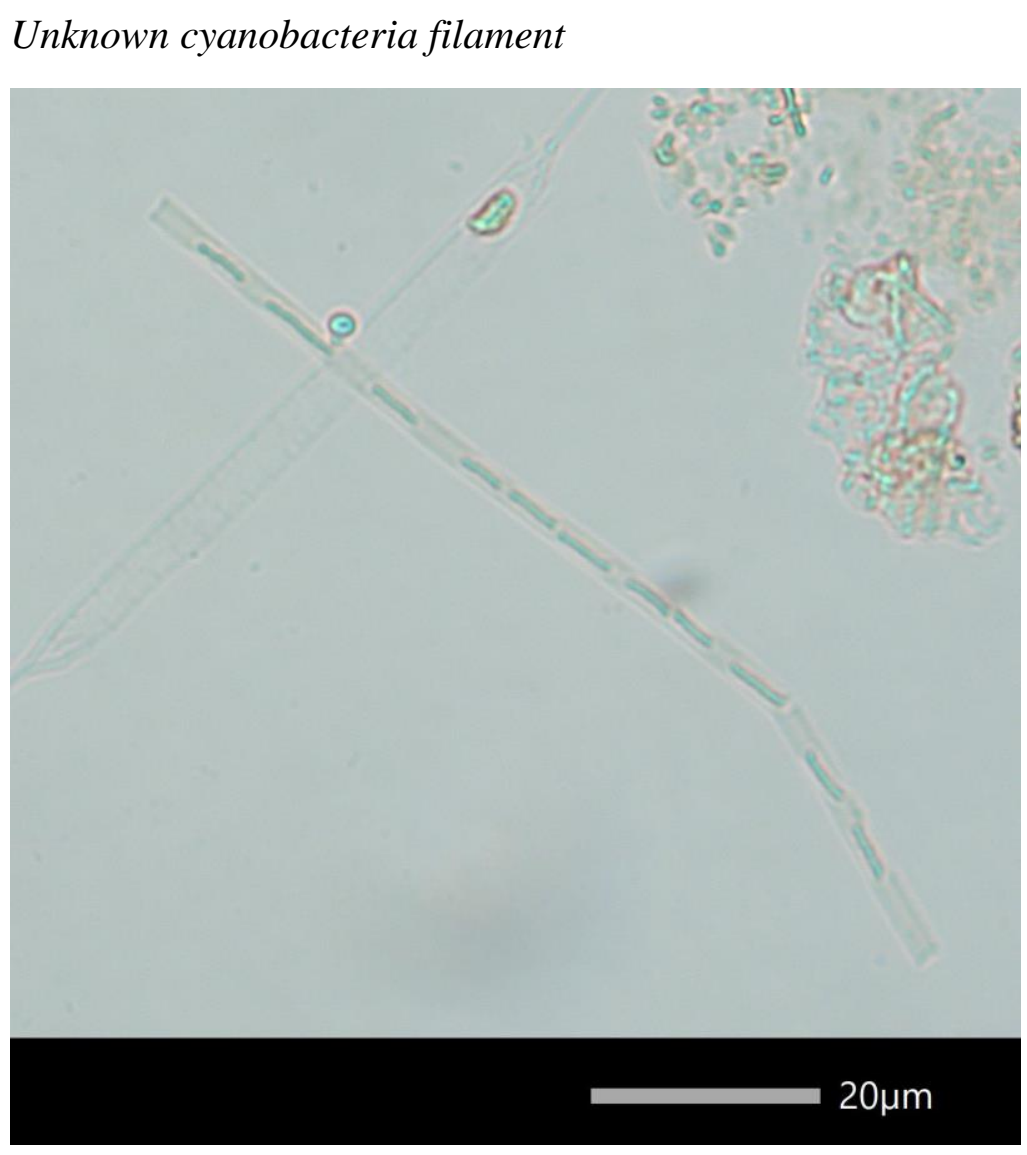

